\title{
FILM AND VIDEO CENSORSHIP IN NEW ZEALAND, 1976-1994
}

\author{
BY \\ DUNCAN GRAHAM ANDERSON
}

A thesis

submitted to the Victoria University of Wellington in fulfilment of the requirements for the degree of Doctor of Philosophy

Victoria University of Wellington (2017) 


\section{Abstract}

This thesis is an historical analysis of cinema and video censorship in New Zealand focusing on the period from 1976 to 1994. This is bookended by two significant changes in censorship legislation: the introduction of the concept of "injurious to the public good" as the guiding principle for film censorship in 1976, and the consolidation of censorship of film, video and other publications under one censorship authority in 1993 legislation (which came into force in 1994). My theoretical approach can be broadly classified as institutionalist political economy. The emphasis is on what Des Freedman regards as the "deeply political" nature of media policy development and implementation ${ }^{1}$, as well as the role of many key actors, including politicians and civil servants, but also lobbyists and pressure groups, and "the importance of informal as well as formal modes of policy behaviour". ${ }^{2}$ Also, rather than simply looking at censorship decisions as the work of individuals, I have examined the way in which, as B. Guy Peters notes, "structures persist while individual members of those structures come and go", and that "structures (institutions) create more regularity of human behaviour than would otherwise exist". ${ }^{3}$ Rather than attempting to provide an exhaustive narrative of film censorship during this period, the focus is on detailed case studies of individual films which were the subject of censorship controversy in New Zealand, including Last Tango in Paris, Mad Max, Life of Brian, I Spit on Your Grave, Hail Mary and Henry: Portrait of a Serial Killer. As these were contentious decisions, with a number of different voices competing for discursive legitimacy, they help to illustrate what Annette Kuhn describes as the idea of censorship as "a matter of relations...a process, not an object", emphasising "the interactions between the various institutional practices involved....the relations between them, the ensemble of practices condensed in any one instance of film censorship". ${ }^{4}$ These case studies also provide significant insight into the decision-making process of the film censors, demonstrating that this goes far beyond "objective" judgements about the manifest content of the films, and into more contentious and subjective areas such as the

\footnotetext{
${ }^{1}$ Des Freedman, The Politics of Media Policy (Cambridge: Polity Press, 2008), 1.

2 lbid., 217.

${ }^{3}$ B. Guy Peters, "Institutional theory: problems and prospects." In Debating institutionalism, edited by Jon Pierre, B. Guy Peters and Gerry Stoker (Manchester: Manchester University Press, 2008), 6. ${ }^{4}$ Annette Kuhn, Cinema, censorship, and sexuality, 1909-1925 (London: Routledge, 1988), 127.
} 
perceived tone of films (how they present certain content, rather than simply the content itself), views on media effects, the imagined audience, and the wider societal context. The decisions made by the censors depend very much on how these various factors are weighed, and which are given the most importance in the decision-making process. I have also examined the operation of formal home video censorship in New Zealand, which was introduced in 1987, taking a broader approach rather than focusing on individual film case studies, as no individual videos resulted in the level of controversy or media coverage as the film case studies. 


\section{Acknowledgements}

Firstly, I would like to thank my supervisors, Dr. Peter Thompson, Dr. Miriam Ross and Dr. Alfio Leotta, for their assistance, support and encouragement. I would also like to thank my interviewees, Arthur Everard, Jane Wrightson and Dr. Andrew Jack, for their time and insights. I also acknowledge the assistance of the Office of Film and Literature Classification, as well as the financial assistance of Victoria University through the Victoria Doctoral Scholarship and Victoria Doctoral Submission Scholarship. Finally, I would like to thank my family for their support during the last few years. 


\section{Table of Contents}

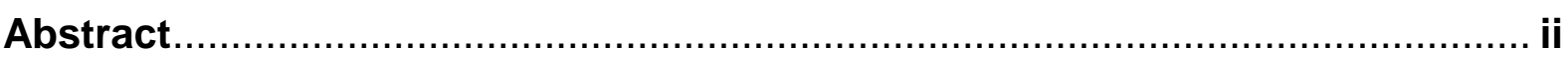

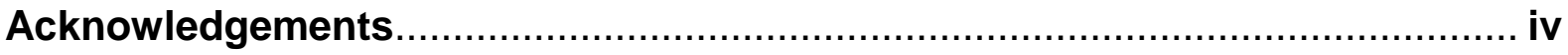

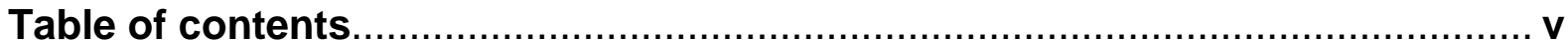

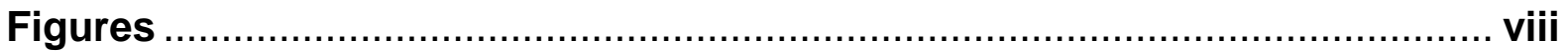

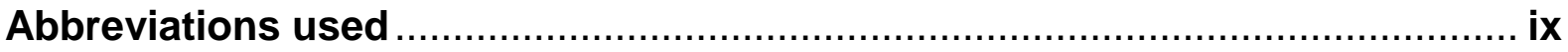

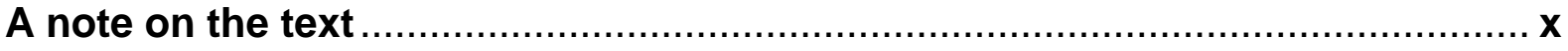

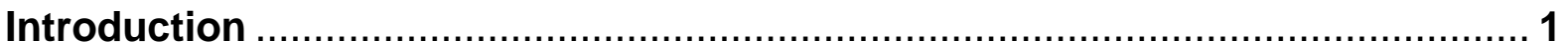

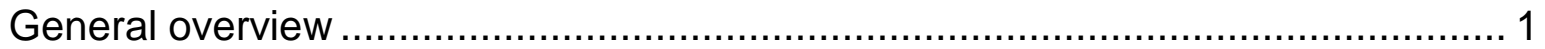

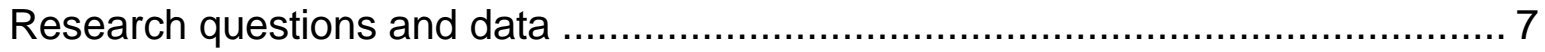

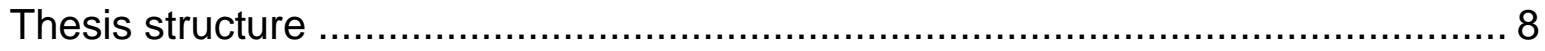

Chapter One: Literature Review and Theoretical Framework ...................... 15

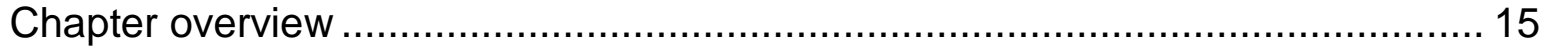

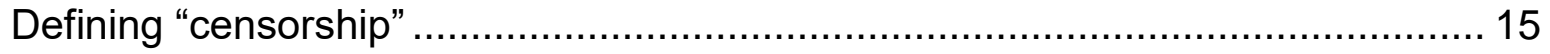

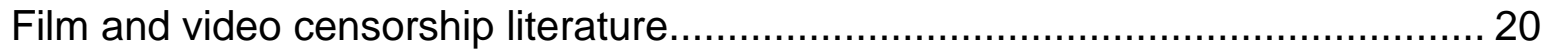

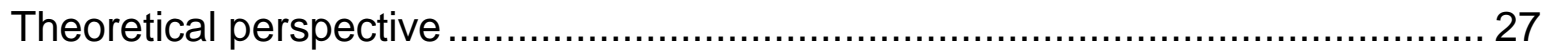

Film and video censorship in New Zealand - an overview............................... 35

Chapter summary ..................................................................................... 46

Chapter Two: Methodology and Data Collection ....................................... 47

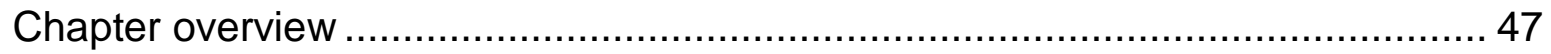

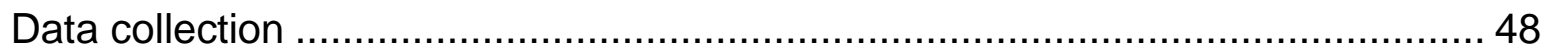

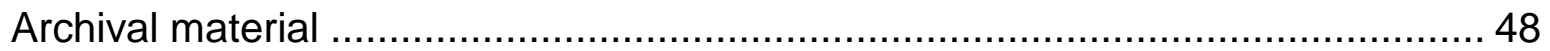

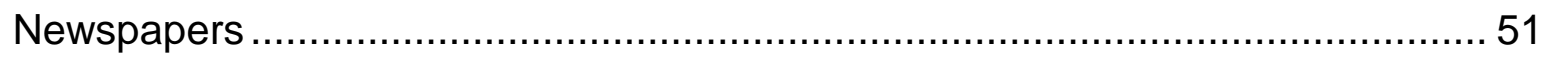

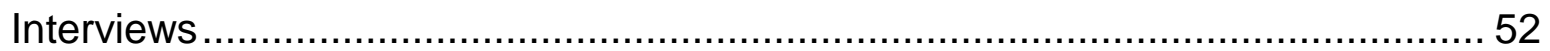

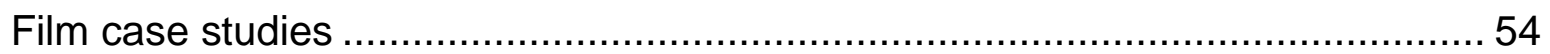

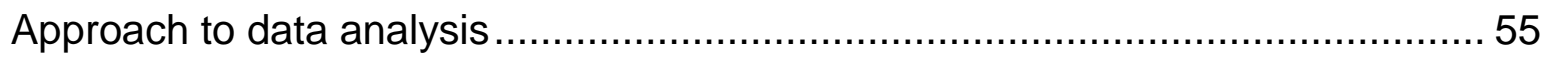

Typology of censorship decision-making rationalisation ............................... 59

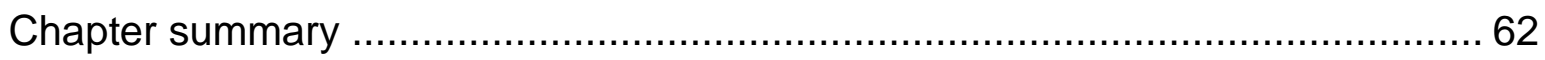

Chapter Three: Chief Censor Bernard Tunnicliffe, 1976-1983 ......................63

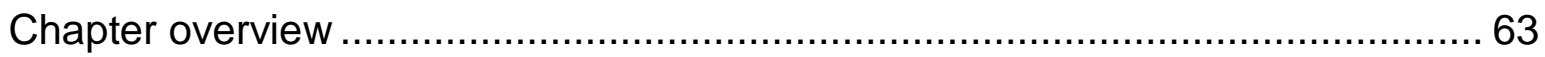

Last Tango in Paris - historical narrative .................................................. 64

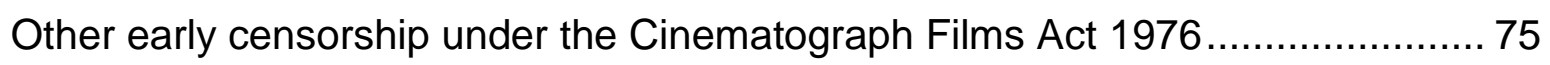

Last Tango in Paris - analysis ........................................................ 76 


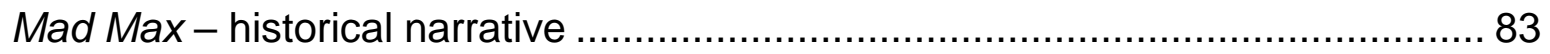

The Films Censorship Board of Review .................................................. 89

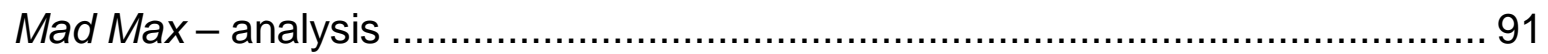

Angel Mine and Goodbye Pork Pie - historical narrative ................................. 94

Angel Mine and Goodbye Pork Pie - analysis ........................................... 105

Life of Brian - historical narrative ............................................................ 106

Life of Brian - analysis ................................................................... 112

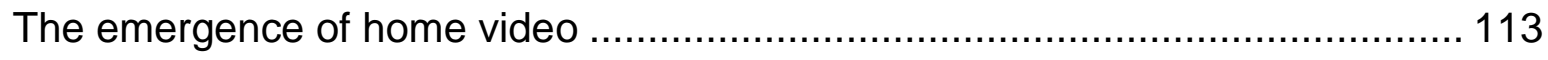

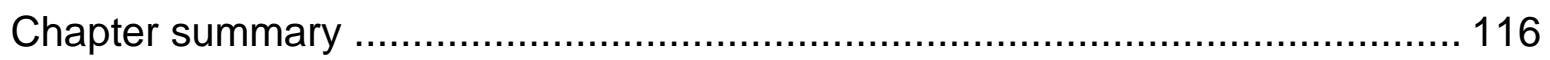

Chapter Four: Chief Censor Arthur Everard, 1984-1987 ........................ 117

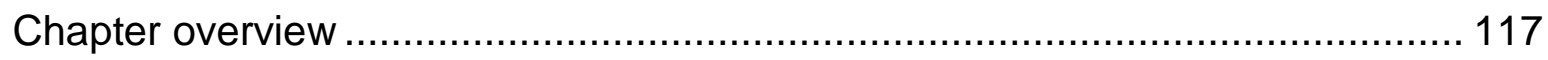

I Spit on Your Grave and The Driller Killer - historical narrative ...................... 117

I Spit on Your Grave and The Driller Killer - analysis .................................. 135

The problem of home video censorship .................................................. 139

The "video nasties" compilation tape - historical narrative.............................. 142

The "video nasties" compilation tape - analysis........................................ 149

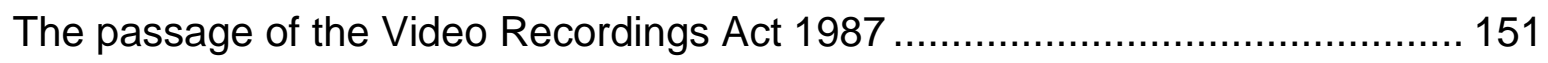

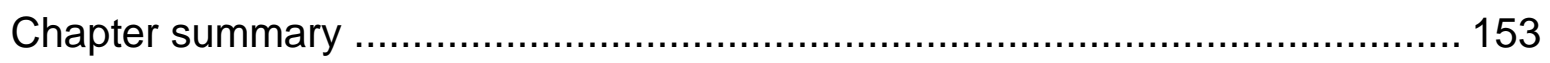

Chapter Five: Chief Censor Arthur Everard, 1987-1990 ........................... 154

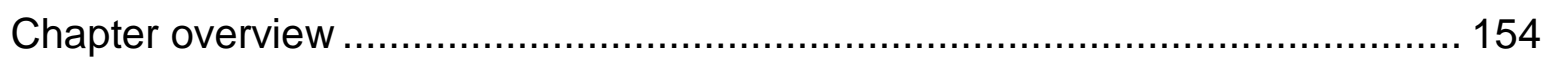

Hail Mary and The Last Temptation of Christ - historical narrative .................... 155

Hail Mary and The Last Temptation of Christ - analysis .............................. 167

Censorship by the Video Recordings Authority, 1987-1990 - historical narrative169

Censorship by the Video Recordings Authority, 1987-1990 - analysis .............. 175

Censorship by the Video Recordings Board of Review, 1987-1990 - historical

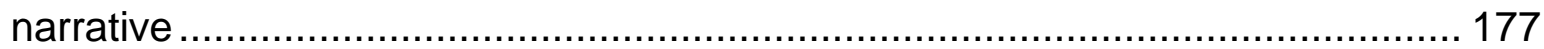

Censorship by the Video Recordings Board of Review, 1987-1990 - analysis... 181

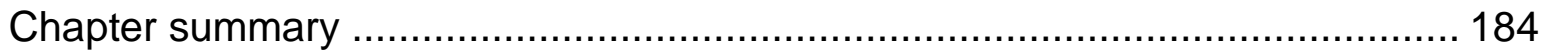

Chapter Six: Chief Censor Jane Wrightson, 1990-1994 .......................... 186

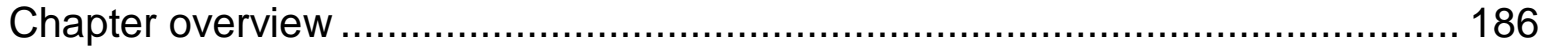

A period of transition ......................................................................... 187

A new Chief Censor ......................................................................... 191

Notable early decisions by Jane Wrightson ................................................. 193

Formal consultations prior to Henry: Portrait of a Serial Killer............................. 195

Henry: Portrait of a Serial Killer - historical narrative ...................................... 196 
Henry: Portrait of a Serial Killer - the "home invasion" scene ............................ 203

Henry: Portrait of a Serial Killer - analysis .................................................... 205

Salò, or the 120 Days of Sodom - historical narrative .................................... 210

Salò, or the 120 Days of Sodom - analysis ..................................................... 213

The role of the Video Recordings Authority, 1990-1994................................. 215

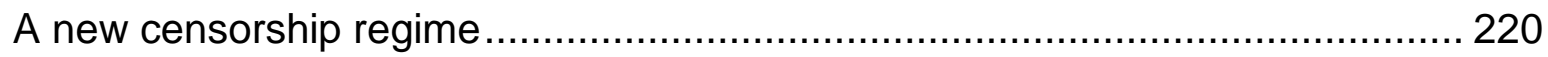

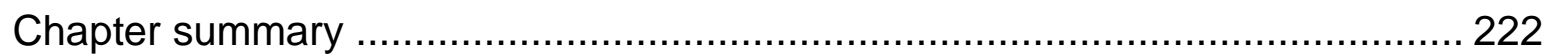

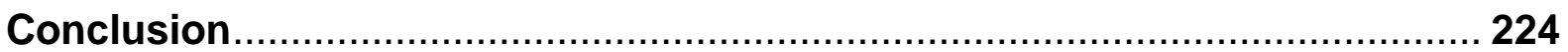

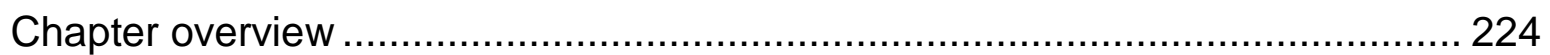

Empirical contributions to academic literature on censorship............................. 224

An institutionalist political economy approach ................................................. 225

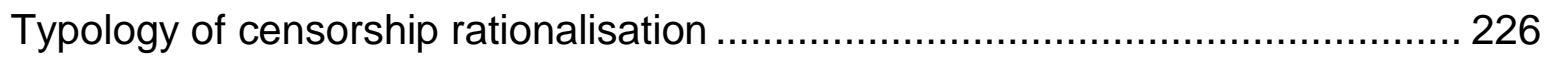

Change and continuity in censorship practice, 1976-1994 .............................. 229

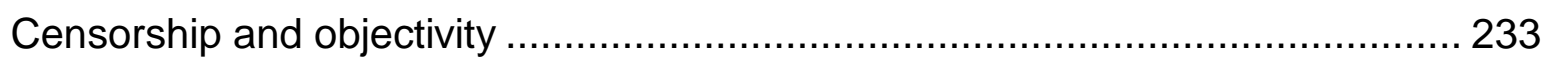

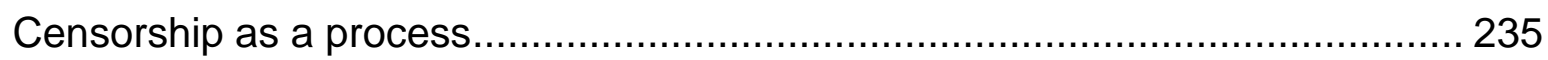

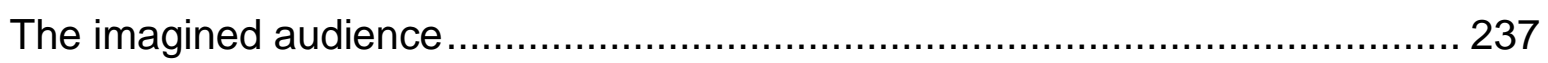

Technological change and contemporary censorship .................................... 238

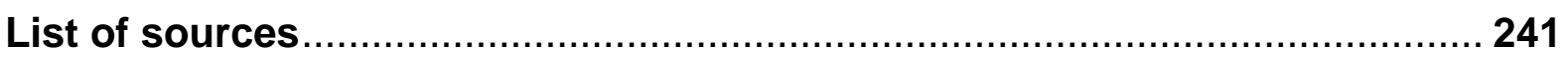

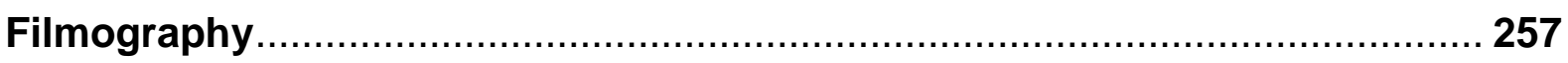

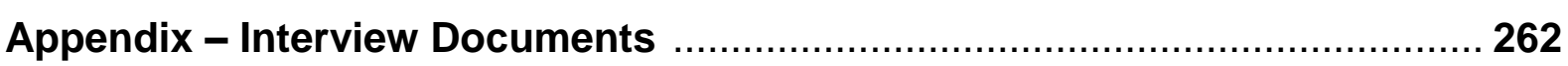




\section{Figures}

Figure 1: Women Against Pornography cartoon of Arthur Everard (from ADNB 23136 Box 7 - Pressure Groups - WAP Women Against Pornography 1984-1994). (page 126)

Figure 2: Comparison of UK and New Zealand video covers of The Driller Killer. (page 131)

Figure 3: Photograph from The Dominion, 10 October 1985, depicting Peter Kruger, John Banks and Patricia Bartlett watching The Driller Killer. (page 148)

Figure 4: The New Zealand VHS cover of Henry: Portrait of a Serial Killer. (page 203)

Figure 5: Timeline of censorship case studies, indicating modes of rationalisation of decisions. (page 228) 


\section{Abbreviations used}

OFLC - Office of Film and Literature Classification

SPCS - Society for the Promotion of Community Standards

VRA - Video Recordings Authority

VRBOR - Video Recordings Board of Review

WAP - Women Against Pornography 


\section{A note on the text}

All quotations are presented as they are in the original source (including capitalisation, emphasis and punctuation) unless otherwise indicated. 


\section{Introduction}

\section{General overview}

As a topic that centres on a range of important issues such as political liberty, the role of the state, and the importance of artistic and political expression in society, censorship has always been a topic that has attracted considerable debate and controversy, both in academia and in wider public discourse. This is as true for New Zealand as for any other country, and censorship here has a long and varied history. This thesis examines the dynamics of censorship policy and practice in New Zealand, through an historical account of film and video censorship during the period from 1976 to 1994, addressing the interplay between the censor as institutional agent and the broader structural constraints. This was a time of significant legislative change surrounding censorship, bookended by two pieces of legislation that represented fundamental shifts in the theory and practice of censorship, as well as a period of technological developments such as the rise of home video, and social changes such as the growth of second-wave feminism, evidenced in New Zealand censorship history through the activities of activist groups such as Women Against Pornography. The existing literature on film and video censorship in New Zealand covers a number of academic disciplines, as well as including non-academic works. This thesis adds to this body of literature by focusing on the period in detail through the use of previously unexamined archival records.

While there are aspects of this period in New Zealand censorship that are historically and culturally specific, there is also evidence of concerns that pertain to the wider debates on censorship. Not only is censorship a subject which engenders much controversy, the definition of what actually constitutes censorship has also been an issue of much debate within academia. There is a broad continuum of views on the 
nature of censorship, from very narrow definitions which centre on "top-down" state censorship of existing content, to wide definitions which see censorship as a broad process that permeates all forms of communication in both formal and informal ways.

The theoretical approach for this thesis can be categorised as institutionalist political economy. Rather than focusing solely on individual agency on the part of censors, politicians and the like, or emphasising structural factors at the expense of individual agency, I have taken a middle ground which emphasises the importance of both in each instance of censorship. As part of this approach, I have looked at censorship as a process involving many factors beyond simply the decision of a censorship authority, which Annette Kuhn describes as viewing censorship as "a matter of relations...a process, not an object". ${ }^{1}$ Viewing censorship as a process involves examining the likes of government Ministers, pressure groups, filmmakers and film distributors, as well as the censors themselves, and occurs both before and after the act of classification of a film itself. Rather than being a disinterested process, censorship is, like much media policy implementation, "deeply political" and involves a contest for power and discursive legitimacy between the various parties involved. ${ }^{2}$ Institutional theory can help to explain the way in which contextual pressures constrained individual agency and shaped the way in which censorship decisions were undertaken and rationalised.

As John Corner notes when discussing the historiography of television, periodisation is one of the challenges of designing historical research projects, as different ways of identifying time periods can create distortions in an account, such as the "treacherousness of decades as a way of classifying historical change", but can also allow for "clarity of analysis and coherence of account". ${ }^{3}$ The period examined in this thesis is bookended by two of the most important changes in censorship legislation in New Zealand, the 1976 Cinematograph Films Act and the 1993 Films, Videos and Publications Classification Act, which came into force in 1994.

Prior to 1976, film censorship legislation in New Zealand provided wide discretionary powers to censors starting with the Cinematograph-film Censorship Act in 1916, the

\footnotetext{
${ }^{1}$ Annette Kuhn, Cinema, censorship, and sexuality, 1909-1925 (London: Routledge, 1988), 127.

2 Des Freedman, The Politics of Media Policy (Cambridge: Polity Press, 2008), 1.

3 John Corner, "Finding Data, Reading Patterns, Telling Stories: Issues in the Historiography of Television." In Mass Communication Research Methods: Volume 1, edited by Anders Hansen (Los Angeles: Sage, 2009), 246.
} 
country's first film censorship law. This Act stated that all films had to be approved by the censor before public exhibition, and that a film would not be approved

in the case of any film which, in the opinion of the censor, depicts any matter that is against public order and decency, or the exhibition of which for any other reason is, in the opinion of the censor, undesirable in the public interest. ${ }^{4}$

As Paul Christoffel notes, both the phrases "in the opinion of the censor" and "undesirable in the public interest" were "sweeping" and gave the censor a large amount of individual discretion. ${ }^{5}$ The use of the phrase "for any other reason" also left the legislation open to broad interpretation, in contrast with more recent legislation which has tended to more specifically identify issues which the censor should consider. The 1961 Cinematographic Films Act retained similar language, containing the slightly modified wording "in his [sic] opinion", and still containing the words "for any other reason". Watson and Shuker note that the law continued to give the censor "enormous power...to make decisions based on personal beliefs". ${ }^{6}$

1976 saw the passage of the Cinematograph Films Act, which removed this "discretionary clause", introduced the concept of "injurious to the public good" as a justification for films to be banned or cut, and gave the censor guidelines on what kinds of material could be considered "injurious". ${ }^{7}$ As Christoffel notes, this new law represented "more liberal film censorship". ${ }^{8}$ This lessening of censorship restrictions provides a useful starting point for my analysis, which focuses on how both legislative change and institutional culture influenced censorship practice.

In 1993, the Films, Videos, and Publications Classification Act was passed, and it came into force the following year. This is the legislation under which film and video censorship operates to this day. This represented another fundamental change in New Zealand censorship legislation, bringing together censorship of film, video and other publications under one body, the Office of Film and Literature Classification. Arguably, it also restricted the individual discretion of censors even further, by listing specific

\footnotetext{
${ }^{4}$ Cinematograph-film Censorship Act 1916, Section 4(3).

5 Paul Christoffel, Censored: A short history of censorship in New Zealand (Wellington: Department of Internal Affairs, 1989), 12.

${ }^{6}$ Chris Watson and Roy Shuker, In the Public Good? Censorship in New Zealand (Palmerston North: The Dunmore Press, 1998), 47.

${ }^{7}$ Watson and Shuker, 51.

${ }^{8}$ Christoffel, 34.
} 
material to be considered "objectionable", for example material which "promotes or supports... sexual conduct with or upon the body of a dead person" and "the use of urine or excrement in association with degrading or dehumanising conduct or sexual conduct", which had not been explicitly identified in previous censorship legislation. ${ }^{9}$ Watson and Shuker note that this was "attacked by liberals as a 'shopping list"" 10 , while Diana Gardner suggests that it constituted an "instantly bannable content clause, with no room to consider context or artistic merit. ${ }^{11}$ Since this can be seen as representing another significant paradigm shift in the nature of New Zealand censorship, this makes an appropriate place to bookend the scope of my research.

The timeframe which this thesis covers was also a period of significant technological change which impacted on the practice of film censorship, most notably the rise of home video. Video Cassette Recorders were initially available in New Zealand around 1980, and became increasingly popular as prices fell - it was estimated that by April 1988, "roughly half of New Zealand households owned or hired a VCR". ${ }^{12}$ Caetlin Benson-Allott argues that video has significantly changed film spectatorship, and "[w]e must attend to the ways video platforms affect the motion picture experience if we want to continue to comment on the ideological significance of motion pictures for contemporary culture, politics and subjectivity". ${ }^{13}$ Home video has also been the site of "moral panic", most famously the controversy over "video nasties" in the United Kingdom. ${ }^{14}$ As Christoffel notes, in New Zealand, "as in other countries", the increasing popularity of home video "was accompanied by controversy". 15 The most significant legislative change during this period was the Video Recordings Act in 1987, which brought in formal home video censorship. Prior to this, video censorship had come under various informal institutions, such as industry self-rating of videos, customs

\footnotetext{
${ }^{9}$ Films, Videos and Publications Classification 1993, Section 3(2).

10 Watson and Shuker, 58.

11 Diana Gardner, "Censorious New Zealanders: Pornography, Corruption and Harm to Women," (Master's thesis, University of Auckland, 1995), 21.

${ }^{12}$ Christoffel, 38.

${ }^{13}$ Caetlin Benson-Allott, Killer Tapes and Shattered Screens: Video Spectatorship from VHS to File Sharing (Berkeley: University of California Press, 2013), 2

14 This topic has been extensively covered by Martin Barker and Julian Petley, as well as more recently by Kate Egan.

${ }^{15}$ Christoffel, 38.
} 
seizures, and classification of videos for private viewing by the film censor (even though this was not legally required unless the video was to be exhibited publicly).

Another significant reason for undertaking this study has been my own interest in the subject of censorship, and my related interest in films noted for the controversy which has surrounded them, particularly horror and exploitation films. As these are films which have both attracted censorship controversy and which have been often viewed as "disreputable" films, the censorship discourse around such films is rather different from that surrounding controversial arthouse films. The 1976 censorship legislation is particularly significant in this regard, as it specified that artistic merit should be taken into account when the Chief Censor was examining films.

Rather than trying to provide a comprehensive history of film and video censorship during this period, I have decided to focus on case studies of individual films which illustrate important aspects of the censorship process in New Zealand. Instead of looking at films which were passed by the censor without any significant controversy or public comment, or films that were banned with little controversy or comment (in the case of New Zealand, often violent pornography), I have chosen more "borderline" cases. These are films which engendered arguments from multiple positions in the debate on censorship, and which created discussion regarding their degree of artistic merit or potential harm. This selection of cases allows for an examination of the extent to which the censorship process was not simply an "objective" application of the letter of the law to a particular film, but something much less tidy and involving highly subjective decisions about which factors to give the greatest weight to when making a censorship decision. Such films are also a useful way to examine changes in censorship practice, as the way they are treated tends to vary more significantly over time than less controversial films.

It is often assumed that censorship tends to become less restrictive over the passage of time. While this is partly true in the period I am studying, the overall narrative of film and video censorship in New Zealand from 1976 to 1994 is a little more complex. The 1976 film censorship legislation freed up the film censors to be more liberal and to ban or cut films to a lesser extent, but the initial period under Chief Censor Bernard Tunnicliffe was demonstrably more restrictive than under his successors Arthur Everard and Jane Wrightson. The 1987 video censorship legislation was also much 
more liberal than that enacted several years earlier in the United Kingdom. New Zealand did not experience the same level of moral panic around so-called "video nasties", and the emphasis of the new legislative regime was on providing information for video consumers, rather than on heavily restricting access to home video. Both politicians and censors demonstrated a rational, evidence-based approach, focussing on the "middle group" between the two extremes of pro-censorship and anticensorship campaigners. Also, despite the efforts of groups such as the Society for the Promotion of Community Standards, a morally conservative lobby group headed by former nun Patricia Bartlett, the period I have investigated is notable for the lack of large-scale "moral panics" around issues of censorship - while there was a very vocal minority opposed to some of the censors' decisions, the wider public as a whole did not share these concerns.

However, towards the end of the period of this study, film and video censorship did become more restrictive in some respects. A number of films were banned on home video which had earlier been passed by the film censor, and there was a tightening up of video censorship legislation as it was seen that under the new system too many films on video were getting unrestricted classifications rather than legally enforceable age restrictions. The so-called "shopping list" of bannable material introduced by the new censorship legislation in 1993 was something which had been desired by campaigners for stricter censorship such as the Society for Promotion of Community Standards, but opposed by others such as former Chief Censor Arthur Everard. While the changes in legislation were due in large part to recommendations made by the 1988 Ministerial Committee of Inquiry into Pornography and the acceptance of feminist views on what constituted pornography, it can also be seen as a partial victory for more socially conservative campaigners such as Patricia Bartlett and the Society for the Promotion of Community Standards.

Within this overarching narrative of film and video censorship in New Zealand, there are a number of significant recurring themes which also have relevance outside this specific time period and for the topic of censorship in general, not just in New Zealand and not only regarding censorship of film and video. These include the tension between claims of objectivity on the part of the censors and the subjective and often "messy" reality of the decision-making process, as well as the way in which changes in technology (in the case of this thesis, the rise of home video) affect the way in which 
censorship is practised and understood. While there were significant differences in the way different censors and different censorship bodies operated, and changes over time within particular censorship institutions, the recurrence of these themes suggests that they cannot simply be explained by particular historical circumstances and context, but are inherent in the process of censorship as it is practised in democratic countries.

\section{Research questions and data}

My investigation of film and video censorship is centred around two research questions. These questions focus on uncovering the way in which censorship was practised in the period under examination, as well as attempting to explain both historical continuity and change. As well as revealing much about censorship in New Zealand from 1976 to 1994, these questions also have wider significance regarding the implementation of media policy and how institutions and individuals negotiate the contested discursive space around such policy implementation. The research questions are:

1. What continuities and changes were there in the way in which film and video censorship was practised and rationalised in New Zealand during the period from 1976 to 1994 ?

2. How can such continuities and changes be explained in terms of individual agency, institutional pressures, legal requirements, and other factors?

In order to answer these questions, my major source of data is archival material held at Archives New Zealand from the various bodies responsible for film and video censorship during the period from 1976 to 1993, primarily the Film Censor's Office, the Video Recordings Authority, the Cinematograph Films Board of Review, the Video Recordings Board of Review, and the Ministry of Internal Affairs. Other sources which I have used include newspapers, interviews with former Chief Censors, and the films for which I have written censorship case studies. However, the primary focus is on presenting an historical narrative on evolving institutional practices based on the archival material, and these other sources have been used to supplement and 
complement that data - this thesis is not an examination of media representations of censorship in New Zealand, an oral history of censorship, or a textual analysis of certain films. As primary source material produced by those with direct involvement in the censorship process, the material in Archives New Zealand provides detailed insight into the rationales and mitigating factors which shaped key censorship decisions, and provides a much more detailed and accurate picture than other potential sources such as media coverage of censorship, which are further removed from the actual practice of censorship by those involved in it.

\section{Thesis structure}

In order to clearly portray a narrative based on change over time, I have organised the material in my thesis in a largely chronological rather than thematic manner. Chapter One covers literature review and theoretical framework, and is divided into four main sections. The first section provides an overview of academic literature covering the different ways in which the term "censorship" itself has been conceptualised. These range from narrow definitions emphasising formal state censorship only, to much broader conceptions which view censorship as something omnipresent in human communication at all levels, and not restricted to purely legally binding censorship. This provides a context for my own conceptualisation of censorship in this thesis. The second section covers literature specifically covering film and video censorship in New Zealand, as well as touching upon the very large body of literature on the topic in other countries, which places this study in a wider scholarly context and highlights the way in which it fills a gap in the existing literature. The third section outlines the main theoretical framework, an institutionalist political economy approach, which emphasises the "deeply political" nature of censorship policy and its implementation, and the various competing interests which attempt to normalise and legitimate their own views on how film and video censorship should operate. ${ }^{16}$ I have also drawn on aspects of rational choice theory and policy-as-discourse, which allow for greater insight into the institutional processes at work. Other theoretical ideas, such as the

\footnotetext{
${ }^{16}$ Freedman, 1.
} 
evolving conceptualisation of media effects, are used to inform the discussion of the way in which those involved in the censorship process rationalised their decisions. The final section of this chapter is a brief chronological overview of censorship history in New Zealand, from the nineteenth century to the present day, with an emphasis on significant developments in film and video censorship. This is largely drawn from existing secondary sources, although it does include some material drawn from archival research.

Chapter Two presents an outline of the methodological approach and the data collected, including the variety of material held in Archives New Zealand, the strengths and weakness of the different types of data, and the means by which the data was analysed through "an iterative process", through which data takes on new meaning after being reread and reinterpreted in light of new data. ${ }^{17}$ I discuss the way in which my data analysis also involved the process of triangulation between different types of documentary material, as well as between documentary material and interviews, in order to provide a more accurate and detailed account. This chapter then explains how this process led to my development of a typology of ways in which censorship decisions were rationalised and explained outside of simply the manifest content of the films being examined, which in turn fed back into my analysis of each case study and formed the basis of the analytical sections following the narratives of each film's New Zealand censorship history. This typology is outlined in this chapter.

Chapter Three begins my analysis of the data, and covers the period from 1976 to 1983, from the passage of the 1976 Cinematograph Films Act to the 1983 Films Act, and encompassing the tenure of Chief Censor Bernard Tunnicliffe. The film case studies examined are Last Tango in Paris (1972), Mad Max (1979), and Life of Brian (1979), as well as the New Zealand-made films Angel Mine (1978) and Goodbye Pork Pie (1980). The case study of Last Tango in Paris provides an example of a single film examined under both the 1961 Cinematograph Films Act and the 1976 Cinematograph Films Act, with only a few years between the decisions, thus providing a unique example of the similarities and differences in which the way the film was handled by censors under these different legislative regimes. The film was banned under the 1961 Act, a ban upheld at two separate appeals, and eventually passed uncut after the

${ }_{17}$ Michael R. Hill, Archival Strategies and Techniques (Thousand Oaks: Sage, 1993). 
passage of the 1976 Act. However, rather than simply suggesting that more liberal legislation can allow for a previously banned film to be passed by the censors, this case study raises other issues. These include the way in which the implementation of censorship legislation is not a straightforward matter and is open to a range of interpretations, how similar rationales can be used by censors even under significantly different legislative regimes, such as the perceived quality and cultural importance of a film, and issues of normative standards in society. Mad Max provides a unique example of a film banned in New Zealand for reasons very specific to the social context of the time, rather than broader concerns over contentious content, as there were concerns about the way in which it portrayed gang violence at a time when the subject was prominent in public discourse. This chapter discusses the major factors in the rationalisation of the ban included the film's perceived high quality and realism, because they were seen as giving the film a greater impact than one which was unrealistic or poorly made. Also important was the appeal to third party authorities outside of the censors themselves as a way to legitimate the decision, with both the Police and Maori Affairs making submissions when the original ban was appealed. Angel Mine and Goodbye Pork Pie, as New Zealand-made films, provide insight into the way in which censorship considerations can form a part of the creative process of filmmaking itself. In both cases, the likely New Zealand censorship classification was an important consideration made by the filmmakers. However, these were in rather different contexts, with Angel Mine being a surrealist arthouse film which the director felt might risk cuts or a ban (but which was eventually passed R18 with no cuts), and Goodbye Pork Pie being aimed squarely at a wide commercial audience, and the producers desiring a lower censorship classification in order to make the film as accessible as possible. The case of Life of Brian, a film targeted by various forms of protest for its alleged blasphemy, provides a notable example of the way in which "imagined" versions of films often play a part in censorship controversy. Most of those who protested against it had not seen it, and their descriptions of the film based on second-hand accounts were at significant variance with the actual film itself. The response of the censors and the Minister of Internal Affairs to the protests demonstrates the way in which complaints about controversial films views as lacking in sufficient first-hand knowledge were not given serious consideration. The justification of the decision of the censors (an uncut R16 classification) was also further legitimated by the use of third party authorities, in this case a consultation with 
members of the public including clergy members, and a distinction drawn between what might be seen by some as offensive and what was genuinely regarded as "injurious to the public good". Overall, this chapter illustrates significant themes that run through the thesis, including the ways in which these films became sites of contested discursive legitimacy, and the range of different rationalisations used to justify censorship decisions, as well as providing more historically specific insights.

Chapters Four and Five cover the period 1983 to 1990, from the passage of the 1983 Films Act to the 1990 Films Amendment Act, and encompass the tenure of Chief Censor Arthur Everard. This period also saw the rise of home video in New Zealand, and the passage of new legislation to cover video censorship with the 1987 Video Recordings Act. The film case studies examined in Chapter Four are I Spit on Your Grave (1978) and The Driller Killer (1979), as well as a short compilation of material from so-called "video nasties" which the Society for the Promotion of Community Standards intended to show to Members of Parliament in order to sway them towards heavily restrictive home video censorship. This tape included material excerpted from both these films, as well as several others. While home video had started to become more widespread in New Zealand during Tunnicliffe's tenure as Chief Censor, it was not until during Everard's tenure that the issue of how home video should be censored or classified really came to the fore. The case of the "video nasties" compilation, as well as two films that had been branded as "video nasties" in the UK, highlighted the way in which certain discourses around censorship and media effects were given greater legitimacy than others, and the way in which groups such as the SPCS and Women Against Pornography attempted to counter what they saw as the increased permissiveness of the new Chief Censor. I Spit on Your Grave was the first decision of the new Chief Censor to create a significant degree of controversy, as the film was passed uncut with an R20 certificate, and was available on video as well as having a brief theatrical release in Christchurch. Many of the complaints about the film stemmed from a letter-writing campaign organised by the SPCS, and as in the case of Life of Brian, these activities are examined in order to determine the extent to which they were given discursive legitimacy. As his predecessor had done, Everard demonstrated a nuanced understanding of the concept of media effects, in contrast with the simplistic views expressed in many of the letters of complaint. The Driller Killer, another "video nasty", was also passed uncut by Everard, and similarly received a short theatrical 
run, this time in Wellington. In the case of both films, the complaints made about them and the responses from the Chief Censor and the Minister of Internal Affairs provide significant insight into the way film censorship worked in New Zealand at the time. The compilation of material from "video nasties", around 20 minutes long, was the same tape that had been shown to British Members of Parliament in an effort to sway them towards restrictive video censorship legislation. The SPCS paid for Superintendent Peter Kruger, who had compiled the material and had been involved with prosecutions of "video nasties" in the United Kingdom, to visit New Zealand and speak on the subject of video censorship. This chapter builds on themes of discursive legitimacy and the variety of rationalisations of censorship decisions, as well as beginning to address the discourse around home video censorship, as home video became much more widespread in New Zealand during this time.

Chapter Five looks at Hail Mary (1985) and The Last Temptation of Christ (1988), as well as the beginnings of formal legal video censorship after the passage of the Video Recordings Act 1987. For the first time since Life of Brian, religion became a significant factor in censorship controversy, with both Hail Mary and The Last Temptation of Christ the target of protests due to their perceived blasphemous content. As with Life of Brian, in these cases the role of "imagined" versions of the films played a major part in the controversy, as the lurid descriptions of the films by those who protested against them contrasted quite markedly with the actual films themselves. Hail Mary was the subject of a protest petition of over 12,000 signatures, and actually resulted in a court case in which it was determined that the Chief Censor had erred on a matter of procedure, although this only occurred after the film had already screened at film festivals. The records of this court case provide an even more detailed first-hand insight into the workings of film censorship than is present in the correspondence and daybooks of the Chief Censor's office. This chapter also looks at the first few years of formal video censorship under the newly created Video Recordings Authority, demonstrating that the lack of well-established institutional practices can lead to decision-making that appears to be inconsistent and erratic, and is sometimes difficult to fully explain. However, there is evidence of rather different forms of decision-making rationalisation than for film censorship at this time, including a degree of conflation of "offensive" and "injurious", and an imagined audience of young and vulnerable viewers, as well as much more subjective and pejorative language than was used by 
the film censors in describing the videos being classified. This chapter addresses the way in which campaigners for greater censorship attempted to gain greater legitimacy for their views through legal channels rather than simply letters and petitions, as well as examining the contrast between the way the newly constituted Video Recordings Authority worked in comparison with the well-established film censorship regime.

Chapter Six covers the period from 1990 to 1994, from the passage of the 1990 Films Amendment Act to the 1993 Films, Videos and Publications Classification Act, and encompasses the tenure of Jane Wrightson, New Zealand's first female Chief Censor, as well as the final years of video censorship under the Video Recordings Act. The film case studies examined are Henry: Portrait of a Serial Killer (1976) and Salò, or the 120 Days of Sodom (1975). Henry was particularly significant as the first "mainstream", non-pornographic film to be banned by the Chief Censor since before Arthur Everard's tenure, a decision that received much media coverage and comment. A range of factors were involved in the rationalisation of this decision are examined, including the film's overall tone, its artistic merit, and its perceived level of realism. The role of a formal consultation by Wrightson on Henry is also examined. Salò was similarly banned, again after a formal consultation. These are both films which lack narrative transparency, and are often ambiguous in their meanings. The difficulty of defining a clear and fixed meaning of these films, not merely their graphic sexual and violent content, meant that the censors' decisions depended very heavily on how certain factors were weighed by the censors in the decision-making process, particularly the "art or exploitation?" dichotomy which they both straddled. This chapter also looks at the final years of video censorship under the Video Recordings Authority, which by now demonstrated a more consistent approach and tended to ban and cut fewer videos than in their first few years. This was also done in a more clear and transparent manner, as the VRA now produced written decisions for every video which they classified.

The final chapter presents my conclusions, addressing how the thesis answers the research questions by discussing the key themes which have arisen from the main chapters, such as the degree of continuity and change throughout the period, the concept of censorship as a process, the way in which censors used the idea of an imagined audience to make their decisions, and the tension between the often stated "objectivity" of censorship decisions and their more subjective reality, although this is 
not a simple binary opposition. The thesis ends with a discussion of the relevance of censorship during the particular historical period examined to contemporary debates about media censorship. 


\section{Chapter One: Literature Review and Theoretical Framework}

\section{Chapter overview}

This chapter is divided into four major sections, and contextualises this thesis within existing academic literature both theoretically and empirically. The first section looks at the way in which the concept of censorship itself has been examined by scholars, and outlines where my own working definition of censorship fits within this literature. The second section covers primarily empirical studies about film and video censorship in practice, both in New Zealand and overseas, to demonstrate how my thesis fills a gap in the existing literature, both methodologically and in terms of the time period and subject matter addressed. Thus, these first two sections raise questions regarding film and video censorship, and the third section outlines the conceptual tools to deal with these questions. These are the primary theoretical approach of institutionalist political economy, as well as supporting theories such as rational choice, the concept of policyas-discourse, and views on media effects. The final section is an overview of New Zealand censorship history as a whole, with a focus on film and video censorship, in order to place the period which this thesis examines, 1976 to 1994, in a wider historical context.

\section{Defining "censorship"}

While "censorship" is a term that would perhaps initially appear easy to define, and is used in everyday language with little critical thought about its meaning, as Terry Flew observes, it is a "term [that] is something of an omnibus for a diverse range of legal 
and regulatory practices, applied to quite distinct materials in very different contexts". ${ }^{1}$ In academic discourse, definitions of censorship have tended to be more precisely defined than the use of the term in everyday discourse, and they fall along a continuum. At one extreme, there is the idea that censorship can be narrowly defined, a "traditional ontology" focusing on legally binding censorship undertaken by official state agents. ${ }^{2}$ Through this paradigm, censorship is seen in binary form, with a "libertarian versus protectionist divide" stressing either opposition to or support for censorship with no grey area in between, and emphasising state censorship and legal definitions. ${ }^{3}$ Censorship is seen as something that either exists or does not, and is enacted by an outside force on the object of censorship, what Philip Cook and Conrad Heilmann call the "censee". ${ }^{4}$ It is generally seen as a negative, restrictive force to be avoided as much as possible. Writing in 1998, Frederick Schauer argues that, while prior to the twentieth century, there was a degree of debate as to whether censorship causes harm or was beneficial, "in the last thirty years, the word censorship has become dominantly pejorative". ${ }^{5}$ Similarly, C. Benjamin Cox suggests that when censorship is conceptualised narrowly as official state censorship, "the roles and behaviour [of the censor] have fallen mainly into disrepute". ${ }^{6}$ While newer ideas of censorship, characterised by Nicole Moore as the "new censorship scholarship"7 have largely overtaken such views since the late 1980s, this conception of censorship still persists in some recent scholarship. For example, in his introduction to an overview on the subject of censorship by Frank Caso, Richard B. Collins stresses the idea that opposing censorship is necessary to "obtain truthful information", and opposition to censorship is "everyone's duty in a free country". ${ }^{8}$ At the other end of the continuum, censorship is defined very broadly, most clearly exemplified by Sue Curry Jansen in

\footnotetext{
${ }^{1}$ Terry Flew, "From Censorship to Policy: Rethinking Media Content Regulation and Classification," Media International Australia 88, no. 1 (1998): 91.

2 Frederick Schauer, "The Ontology of Censorship." In Censorship and silencing: practices of cultural regulation, edited by Robert C. Post (Los Angeles: Getty Research Institute for the History of Art and the Humanities, 1998), 150.

${ }^{3}$ Nicole Moore, "Censorship Is." Australian Humanities Review 54 (2013), 45.

${ }^{4}$ Philip Cook and Conrad Heilmann, "Two Types of Self-Censorship: Public and Private," Political Studies 61, no.1 (2013):178.

5 Schauer, 147.

${ }^{6}$ C. Benjamin Cox, "The Varieties of Censorial Experience: Toward a Definition of Censorship," The High School Journal 62, no. 8 (1979): 311.

${ }^{7}$ Moore, 47.

${ }^{8}$ Richard B. Collins, "Foreword." In Global Issues: Censorship by Frank Caso (New York: Facts on File, 2008), xii-xiii.
} 
Censorship: The Knot That Binds Power and Knowledge. While Jansen argues that she did not have "iconoclastic intentions" in writing her book, "the established vocabularies of contemporary intellectual discourse" did not provide room for her to articulate the points she wished to make. ${ }^{9}$ Thus, while on one level the book is a history of censorship, it is more significant as a reimagining of what the concept of censorship actually means. Jansen notes that her definition has a sociological emphasis, rather than being "concerned with the formal logic of legal protections of speech rights". ${ }^{10}$ She writes:

My definition of the term encompasses all socially structured proscriptions or prescriptions which inhibit or prohibit dissemination of ideas, information, images, and other messages through a society's channels of communication whether these obstructions are secured by political, economic, religious, or other systems of authority. ${ }^{11}$

Rather than taking a position that the presence of censorship is an "either/or" proposition, definitions at this end of the continuum suggest that censorship is something inherently present in all societies. Jansen argues that both liberal democracies and totalitarian regimes practice censorship, and it is not something that can be avoided or eliminated - liberal democracies "merely replaced church and state censorships with market censorship", and any attempt to suggest that there is a discontinuity between such types of censorship is "largely semantic". ${ }^{12}$ Frederick Schauer similarly argues that censorship is something omnipresent in human communication, and the question is not whether or not something is censored, but who is doing the censoring - "not about whether content should be determined, but...rather about which people and which institutions should be involved in the determining. ${ }^{13}$ Michael Holquist offers up perhaps the most succinct definition of this perspective - "[c]ensorship is". ${ }^{14}$ Since censorship is seen as essentially unavoidable,

\footnotetext{
9 Sue Curry Jansen, Censorship: the knot that binds power and knowledge (New York: Oxford University Press, 1991), 3.

10 Ibid., 221

11 lbid., 221

12 lbid., 4.

${ }^{13}$ Schauer, 163.

14 Michael Holquist. "Corrupt Originals: The Paradox of Censorship." PMLA 109, no. 1 (1994), 16.
} 
it is not viewed in quite so clearly black and white terms as something negative. Robert Post argues that censorship is "productive", and a normal part of free expression. ${ }^{15}$

In her 1988 study of British film censorship in the early $20^{\text {th }}$ century, Cinema, Sin and Sexuality, 1909-1925, Annette Kuhn argues that previous studies had largely understood censorship as "first and foremost an act of prohibition, excision, or 'cuttingout", and that any censored text "is in some sense partial in its representation". ${ }^{16}$ In the case of film censorship, Kuhn suggests that such arguments characterise film censorship "as a one-way street, something that is done to films"17, whereas she conceptualises censorship as "a matter of relations... a process, not an object". ${ }^{18}$ The emphasis is not just on the variety of institutions involved in film censorship, but "the interactions between the various institutional practices involved....the relations between them, the ensemble of practices condensed in any one instance of film censorship" . ${ }^{19}$ Similarly, Judith Butler suggests that censorship "cannot be understood purely in terms of juridical power" if it is understood as a way of producing speech through "constraining in advance what will and will not become acceptable speech". ${ }^{20}$ Thus, censorship is "not merely privative, but formative" 21 , although this is not necessarily to suggest that it is "positive or beneficial". ${ }^{22}$

Theoretical positions on the nature of censorship can thus fall at a number of places along this continuum - the range of academic ideas is far from binary. For example, work on censorship that stresses the primary significance of state censorship has not necessarily emphasised only formal legal censorship. Frederick Schauer suggests that such views on censorship have "become sufficiently inclusive" to acknowledge that coercive government power can work indirectly as well as overtly ${ }^{23}$, and sometimes external coercion constituting a form of censorship "may often be nongovernmental rather than governmental", although he does note such wider

\footnotetext{
${ }^{15}$ Robert Post, "Censorship and Silencing," Bulletin of the American Academy of Arts and Sciences 51, no. 5 (1998): 34

${ }^{16}$ Annette Kuhn, Cinema, censorship, and sexuality, 1909-1925 (London: Routledge, 1988), 2.

17 lbid., 4.

18 lbid., 127.

19 lbid., 127.

20 Judith Butler, Excitable speech: a politics of the performative (New York: Routledge, 1997), 128.

21 Ibid., 133.

22 Ibid., 132.

${ }^{23}$ Schauer, 150.
} 
understandings of "traditional" censorship still "leave the distinction between the external and the internal untouched". ${ }^{24}$ Nicole Moore critiques the dismissive attitude of some academics towards approaches that emphasise the importance of state censorship, arguing that Simone Barck's work on censorship in East Germany has shown that such censorship is not necessarily "unidirectional or instrumentalist, operating only from above", but is a much more complex process ${ }^{25}$, and Helen Freshwater suggests that the perceived "naivety of popular, or conventional, perceptions of censorship" contrasted with the "theoretical complexity" of newer approaches does the former a disservice ${ }^{26}$ Similarly, not all those favouring a more inclusive definition of censorship see it as broadly as Jansen does. Holquist recognises that there is a need to "discriminate between [censorship's] more and less repressive effects" ${ }^{\prime 2}$, and Post argues for an approach to censorship that keeps the "values and concerns" of older approaches which emphasise the importance of state censorship, while simultaneously adopting the "analytic force" of approaches such as Jansen's. ${ }^{28}$

As this suggests, both extremes of the continuum have significant weaknesses. Focusing heavily on a narrow definition of censorship as purely state censorship has the potential to render the subject uninteresting, and provides limited scope for an analytical approach. For example, Post suggests that such an approach leaves censorship as "a very dull subject" providing "little of analytic interest" 29 , while Jansen argues "that there [was] very little left to say" on the subject when the dominant paradigm was that of state censorship. ${ }^{30}$ However, taking an approach akin to that used by Jansen can be too all-encompassing, and attempting to allow for a more analytical approach can paradoxically make the term less analytically useful. Moore argues that a definition that is "too expansive...can render the term ineffective as a descriptor"31, and Post acknowledges that there is a danger of "flatten[ing] distinctions

\footnotetext{
24 Schauer, 151.

25 Moore, 53.

${ }^{26}$ Helen Freshwater, "Towards a Redefinition of Censorship," Critical Studies 22 (2004), 228.

27 Holquist, 16.

28 Post, 34-35.

29 lbid., 32.

30 Jansen, 3.

31 Moore, 51.
} 
among kinds of power". ${ }^{32}$ Freshwater similarly argues that "new censorship scholarship" potentially plays down the difference between "hard" and "soft" control, and "can certainly appear to overwhelm or trivialise" the significance of censorship as it has traditionally been conceived, asking the pertinent question "[h]as censorship been redefined out of existence?". 33

For this thesis, my working definition of the concept of censorship is positioned between the two extremes of the continuum, taking elements from both. I disagree with Jansen that the distinction between state censorship and other, less formal forms of censorship is largely "semantic", and while I recognise the importance of both, the unique nature of state censorship is a major part of my research. However, even within state censorship, there is still room to examine the nature of power relations between key actors through the use of a theoretical approach emphasising political economy and decision-making.

\section{Film and video censorship literature}

While the studies discussed above focus largely on the way in which the concept of censorship itself has been conceived, it is also necessary to place my thesis within the context of more empirical studies of the practice of censorship, both within and outside New Zealand. While film and video censorship in New Zealand between 1976 and 1994 has been addressed in a variety of previous studies, this thesis takes a different theoretical and methodological approach from most of these prior accounts. This thesis draws heavily on previously unexamined archival material to provide a detailed historical narrative, providing a detailed study of a particularly important period using archival material that has not been previously utilised by other researchers, and indepth case studies of the censorship of key individual films that have only been addressed briefly (if at all) in the existing literature.

Studies on film and video censorship in New Zealand, both published and unpublished, can be broadly grouped into four categories based upon their academic

\footnotetext{
32 Post, 34.

${ }^{33}$ Freshwater, 240.
} 
focus - media studies approaches, sociological approaches, historical approaches and legal approaches, although these often overlap. The most significant account from a media studies perspective is In the Public Good? Censorship in New Zealand by Chris Watson and Roy Shuker, published in 1998. The authors look at both historical background and then-current censorship practice, "trac[ing] the historical development and contemporary nature of censorship in New Zealand"34. While the book also addresses a wide spectrum of media forms - books, magazines, comics, video games, radio, the internet and television - two of the chapters directly address the subject matter and time period covered in this thesis - "From The Wild One to Reservoir Dogs: Film Censorship Since 1950", addressing censorship in the cinema, and "Video Nasties?", addressing the rise of home video technology and the censorship response. While Watson and Shuker do discuss the period from 1976 to 1994 in some detail, there is still much that can be said on these topics, as the book does not utilise primary source material held by Archives New Zealand, which was not publicly available at the time of publication. In particular, Watson and Shuker do make reference to the treatment of a number of films by the censors, but archival material has allowed for more detailed censorship case studies of individual films.

Shuker had also published work on censorship before this book, and his work on video censorship in particular takes a sociological approach. Watson and Shuker's chapter on video censorship in In the Public Good? is based upon earlier articles by Shuker on the subject. The first of these, "Video nasties': censorship and the politics of popular culture', was published in New Zealand Sociology in 1986. While Shuker uses the term "video nasties" which had been coined in the UK in reference largely to violent horror films, the article focuses more on pornography than horror, arguing that state censorship of videos is "the wrong approach to resolving what it is really an issue of cultural politics, particularly concerned with the construction of sexuality". ${ }^{35}$ This article is revised and republished in 1990 in a research monograph by Shuker, Roger Openshaw and Janet Soler, Youth, Media and Moral Panic in New Zealand (From Hooligans to Video Nasties), acknowledging developments that had occurred since 1986. These include the creation of the Video Recordings Authority in 1987 to classify

\footnotetext{
${ }^{34}$ Chris Watson and Roy Shuker, In the Public Good? Censorship in New Zealand (Palmerston North: The Dunmore Press, 1998), 7.

${ }^{35}$ Roy Shuker, "'Video nasties': censorship and the politics of popular culture," New Zealand Sociology 1, no.1 (1986): 64.
} 
(and potentially ban) videos, and the 1987 High Court challenge by the Society for the Promotion of Community Standards against two pornographic videos passed by the film censor. ${ }^{36}$ The sociological concept of the "moral panic" is also explicitly referenced, and Shuker argues that "[t]he mix of justifiable concern and moral outrage over video censorship during the period 1980-1986 clearly contained elements of a moral panic". ${ }^{37}$

Other accounts taking a sociological approach include theses by Anthony Norwood Hill, Diana Gardner and Michelle Baker. Hill's In the Public Good: Film Censorship, the State and Hegemony is an ethnographic study of film censorship in New Zealand at the time of writing, looking at censorship through the lens of Marxist theories of the state. It is divided into two parts, 'Theoretical and Historical Context' and 'Ethnography of Film Censorship'. The author also emphasises the idea of state censorship as "just one of the many interventions that take place in film production and distribution". 38 Gardner's 1995 thesis Censorious New Zealanders: Pornography, Corruption and Harm to Women focuses on the question of whether the availability of pornography causes harm to women, as feminist critics of pornography have argued, eventually concluding that there is "no convincing evidence" that it does. ${ }^{39}$ The author suggests that the 1993 censorship legislation represented the "government's apparent acceptance of feminist arguments for censorship" 40 , as well as containing what is described as an "instantly bannable content clause", which meant that certain material could be classified as "Objectionable" (which in effect meant that it was banned) without any consideration of artistic merit. ${ }^{41}$ There is also some historical background on New Zealand censorship, as well as discussion of a number of theoretical ideas that will be relevant to my thesis, such as the idea of "moral corruption" as a form of harm ${ }^{42}$ and the issue of how far a government should intervene to protect the "moral

\footnotetext{
${ }^{36}$ Roy Shuker, Roger Openshaw and Janet Soler, Youth, Media and Moral Panic in New Zealand (From Hooligans to Video Nasties) (Palmerston North: Massey University), 1990, 79.

37 Ibid., 80.

38 Anthony Norwood Hill, "In the Public Good: Film Censorship, the State and Hegemony," (Master's thesis, Massey University, 1983), 8.

39 Diana Gardner, "Censorious New Zealanders: Pornography, Corruption and Harm to Women," (Master's thesis, University of Auckland, 1995), 111.

40 lbid., 10

41 lbid., 21.

42 lbid., 55.
} 
health" of children. ${ }^{43}$ Baker's 2006 thesis focuses on the way that New Zealand censorship law was enforced at that time, examining "sites of censorship enforcement" such as cinemas, video stores, and the internet. ${ }^{44}$ However, there is some background on the history of censorship in New Zealand, the difficulty in defining what "censorship" is, and the fact that the need for, and extent of, censorship is highly contested.

Several accounts have taken a primarily historical approach, including Censored: $A$ short history of censorship in New Zealand, by Department of Internal Affairs Research Officer Paul Christoffel, published in 1989. This is a brief narrative overview, at only 46 pages, of the history of all forms of censorship in New Zealand, with little engagement with theoretical understandings of the nature of censorship, which largely makes use of secondary sources such as other books and theses, with some limited use of published primary sources such as the New Zealand Parliamentary Debates. Theses which have a focus on film censorship history include those by Laurie Guy and Lisa Cutfield. Guy's 1992 thesis The Cinematograph Film Censorship Debate in New Zealand, 1965-76 focuses on the period just prior to that covered in this thesis, and Cutfield's 1994 thesis goes back even earlier, looking at censorship of silent films in New Zealand in the period from 1908 to 1928. However, her approach is methodologically similar, emphasising the use of primary source material such as archival material, newspapers, and parliamentary publications, as well as addressing more universal themes such as fear over a "new" medium, the fact that pro-censorship campaigners tended to have little knowledge of the material they were campaigning against, and the idea that censorship can be seen "as much a creative impulse as a repressive endeavour". ${ }^{45}$

The work of Simon Sigley on the history of film culture in New Zealand is also important. In his book Transnational Film Culture in New Zealand (which expands upon the research in his $2003 \mathrm{PhD}$ thesis) ${ }^{46}$, he defines film culture as "the network of discursive and non-discursive activities associated with the idea of film as art. ${ }^{47} \mathrm{In}$

\footnotetext{
43 Gardner, 77.

${ }^{44}$ Michelle Mary Baker, "Policing Publications: Sites of Censorship Classification Enforcement in New Zealand," (Master's thesis, University of Canterbury), 12.

${ }^{45}$ Lisa Cutfield, "Silent Film and Censorship, New Zealand, 1908-1928," (Honours thesis, University of Otago, 1994), 65.

${ }^{46}$ Simon Sigley, "Film culture: Its development in New Zealand, 1929-1972," (PhD thesis, University of Auckland, 2003).

${ }^{47}$ Simon Sigley, Transnational Film Culture in New Zealand (Bristol: Intellect, 2013), 3.
} 
examining this topic, he looks at institutions and activities such as art-house cinemas, film societies, film festivals and university film courses, as well as the importance of film censorship in shaping New Zealand's film culture. His methodological approach also centres around the use of archival material from Archives New Zealand, the New Zealand Film Archive, and elsewhere, and provides detailed historical narratives, such as his account in the New Zealand Journal of History of the struggles of the Wellington Film Society in the 1930s with the censors. ${ }^{48}$ Although Sigley does discuss censorship as part of his wider narrative of the development of film culture in New Zealand, he does not cover film censorship in the period from 1976 to 1994 in the level of institutional detail in this thesis. He does acknowledge the importance of the 1976 Cinematograph Films Act, which meant that "it was accepted that the cinema was not a public place and that the censor was not required to be a champion of "public order and decency'. ${ }^{49}$ However, his emphasis is on 'serious' film culture represented by film societies and film festivals, and the fact that clashes over censorship "forced [film culture's] spokespeople to sharpen up their arguments for film as an art worthy of serious consideration alongside books". ${ }^{50}$

The discipline with the widest range of studies concerning New Zealand film and video censorship is law, although these have mostly been unpublished theses. Examples include Andrew Pirie's "Censorship of Films: Conflict in Focus", which looks at censorship law as a form of "conflict resolution", which is "designed to balance the individual interests in freedom of expression and choice against individual moral interests". ${ }^{51}$ Daniel Semren's "Film classification systems in New Zealand and Germany: treatment of sex and violence", Maria On's "Abusive pornography: recognising the harms and extending censorship", and Stephen Donaldson's "The inquiry into "artistic merit" in the Films, Videos and Publications Classification Act 1993: how does it arise and what does it mean?". ${ }^{2}$

\footnotetext{
48 Simon Sigley, "How The Road to Life (1931) Became the Road to Ruin: The Case of the Wellington Film Society in 1933," New Zealand Journal of History 42, no. 2 (2008).

49 Sigley, 2013, 205.

50 Sigley, 2013, 206.

51 Andrew Pirie, "Censorship of Films: Conflict in Focus," (Master's thesis, Victoria University of Wellington, 1976), 29.

52 Daniel Semren, "Film classification systems in New Zealand and Germany: treatment of sex and violence," (Master's thesis, Victoria University of Wellington, 2009), Maria On, "Abusive pornography: recognising the harms and extending censorship," (Master's thesis, Victoria University of Wellington,
} 
Falling outside of the more scholarly body of work on censorship is A Stand for Decency: Patricia Bartlett \& the Society for Promotion of Community Standards 19701995, by Carolyn Moynihan. ${ }^{53}$ This does cover the historical time period of this thesis in some detail, but it is a history commissioned and published by the Society for Promotion of Community standards itself, and is more of a reflection of the Society's views on censorship (as it draws from material they produced, such as newsletters) and thus part of the wider political discourse on censorship, rather than an historically accurate narrative of film and video censorship during the period which it covers.

The body of literature on film and censorship outside New Zealand is extremely wide, but certain studies do have a methodological or theoretical approach that is of relevance to this thesis. Censorship in non-democratic countries works very differently from that in liberal democracies such as New Zealand, and also necessitates a different theoretical approach. As Matthias Niedenführ notes in his account of censorship in the Chinese television industry, "[i]n open societies, policy-making also has to happen, at least on the surface, with public participation", and pluralist theories which "see competition between various stakeholders at the core of media policymaking" are less applicable to more restrictive societies such as China. ${ }^{54}$ The United States is also rather different from New Zealand in terms of film and video censorship, as film has the protection of the First Amendment and there are no state-sanctioned censorship boards, but instead industry censorship through organisations such as the Motion Picture Association of America. This thesis maintains a clear distinction between state censorship and other forms of censorship, which may be coercive but lack formal legal force. Therefore, studies on other democratic countries that have state-sanctioned film and video censorship, in particular the United Kingdom, provide a more appropriate point of comparison. While there is material written on film censorship in non-English speaking Western democracies such as France and Italy,

\footnotetext{
2009), Stephen Donaldson, "The inquiry into "artistic merit" in the Films, Videos and Publications Classification Act 1993: how does it arise and what does it mean?" (Master's thesis, Victoria University of Wellington, 2008).

${ }^{53}$ Carolyn Moynihan, A Stand for Decency: Patricia Bartlett \& the Society for the Promotion of Community Standards 1970-1995 (Wellington: Society for the Promotion of Community Standards, 1995).

${ }^{54}$ Matthias Niedenführ, "The Tug-of-War between Regulatory Interventions and Market Demands in the Chinese Television Industry," The Political Economy of Communication 1, no. 1 (2013): 91.
} 
a number of the key studies have not been translated into English ${ }^{55}$, or emphasise censorship during non-democratic periods in the countries' histories. ${ }^{56}$

Studies with a methodological focus similar to that of this thesis include Kevin Rockett's detailed historical survey Irish film censorship: a cultural journey from silent cinema to internet pornography, and Martin Barker's edited volume The video nasties: Freedom and censorship in the media. Rockett emphasises the primacy of archival research utilising previously unavailable documentary sources. He notes that before gaining access to the records of the Irish film censors, "information had to be filtered through a number of sources, including film distributors and newspaper reports, not all of which could be deemed reliable or objective". ${ }^{57}$ Barker's book, published in 1984 , while the "video nasties" scare in the United Kingdom was still current, and before the Video Recordings Bill had passed in the UK parliament, is explicitly opposed to the hysteria at that time. Barker acknowledges that it is a "partisan" account, and "written with the intention of creating argument", as the campaign against video nasties has tried to shut down any form of argument. ${ }^{58}$ Of particular relevance to this thesis are two articles examining video nasties through detailed textual analysis - "J. Hills is alive: a defence of I Spit on Your Grave" by Marco Starr"59, and "Nasties': a problem of identification" by Martin Barker, which also examines I Spit on Your Grave as well as several other video nasties, arguing that some of the negative reaction to the films may have stemmed not just from the explicit violence but from their difference from mainstream cinema - they lack clear heroes or heroines and the viewer is thus "denied a centre from which to view things". 60

Other studies provide theoretical approaches that provide a useful comparison, particularly surrounding the subject of home video. Writing on the UK "video nasties"

\footnotetext{
55 Albert Montagne, Histoire juridique des interdits cinématographiques en France, 1909-2001 (Paris: Harmattan, 2007), Alfredo Baldi, Schermi proibiti: la censura in Italia: 1947-1988 (Venice: Marcilio, 2002).

56 Virginia Higginbotham. Spanish film under Franco (Austin: University of Texas Press, 1988).

57 Kevin Rockett, Irish film censorship: a cultural journey from silent cinema to Internet pornography (Dublin: Four Courts, 2004), 15.

${ }^{58}$ Martin Barker, ed, The video nasties: Freedom and censorship in the media (London: Pluto Press, 1984), 6.

${ }^{59}$ Marco Starr, "J. Hills is alive: a defence of I Spit on Your Grave." In The video nasties: Freedom and censorship in the media, edited by Martin Barker (London: Pluto Press, 1984).

${ }^{60}$ Martin Barker, "Nasties': a problem of identification." In The video nasties: Freedom and censorship in the media, edited by Martin Barker (London: Pluto Press, 1984), 111.
} 
of the 1980s, Kate Egan argues that while "the term 'video nasty' remains constant"61, discourse surrounding it has seen it refer to a number of different things - "a set of film titles, a specific set of video versions, a set of historical events and a personal consumption experience", with different groups portraying them in different ways. ${ }^{62}$ For example, the press presented them "as an emblem of the worst excesses of horror video", thus emphasising the "cover art and most violent moments". ${ }^{63}$ Similarly, the discourse surrounding key film and video censorship in New Zealand, and particular film and video titles, can be viewed from a variety of vantage points. Caetlin BensonAllott examines the nature of video spectatorship through a number of case studies, arguing that video spectatorship is fundamentally different from "the idealized voyeurism of the cinema", instead "offer[ing] a new fantasy of domestic spectatorial omnipotence". ${ }^{64}$ Such ideas can be related to the way video censorship was conceived of in a different way to cinema censorship in New Zealand and elsewhere. While much has been written on film and video censorship in New Zealand and elsewhere, this thesis fills a gap in the existing literature by focusing on a specific time period in greater depth than previous studies, examining the agency of censors in detail through the extensive use of archival material.

\section{Theoretical perspective}

As Anders Hansen notes, "[r]esearch methods do not, and never should, exist in isolation from theory ${ }^{65}$, and to this end, the data which I have collected has been analysed through a theoretical approach which can be characterised as institutionalist political economy. While this term has been used in a variety of ways by different authors $^{66}$, the focus of this thesis is not on purely economic theories, but instead

\footnotetext{
${ }^{61}$ Kate Egan, Trash or treasure? Censorship and the changing meaning of the video nasties (Manchester: Manchester University Press, 2007), 6.

62 lbid., 5.

63 lbid., 5.

${ }^{64}$ Caetlin Benson-Allott, Killer Tapes and Shattered Screens: Video Spectatorship from VHS to File Sharing (Berkeley: University of California Press, 2013), 206.

${ }^{65}$ Anders Hansen, "Editor's Introduction." In Mass Communication Research Methods: Volume 1, edited by Anders Hansen (Los Angeles: Sage, 2009), xxiii.

${ }^{66}$ For example, John E. Elliott, "Institutionalism as an Approach to Political Economy." Journal of Economic Issues 10, no. 1 (1978), Ha-Joon Chang, Breaking the Mould: An Institutionalist Political
} 
emphasises what Des Freedman regards as the "deeply political" nature of media policy development and implementation, which involves "competing political interests that seek to inscribe their own values and objectives". ${ }^{67}$ This thesis examines the role of many key actors, including politicians and civil servants, but also lobbyists and pressure groups, and "the importance of informal as well as formal modes of policy behaviour". ${ }^{68}$ The institutionalist political economy approach allows us to understand the decision-making process of the censor as an institutional agent responding to a particular set of priorities and contextual pressures.

"Political economy" is a term that has been defined in a number of different ways. Oliver Boyd-Barrett argues that in relation to communications media, political economy approaches "tend to focus on how the work of media institutions relates to the other major institutions of society... and how these influences account for media industrial and professional practices". ${ }^{69}$ Vincent Mosco defines political economy broadly as "the study of the social relations, particularly the power relations, that mutually constitute the production, distribution, and consumption of resources", with "products of communication" such as books, videos, films and newspapers being defined as resources when discussing the political economy of communication. ${ }^{70}$ Political economy based research has also tended to emphasise a "firm hold on a realist epistemology", as well as valuing historical research ${ }^{71}$ and thus analysing media "in historical, social and political context". ${ }^{72}$ As Janet Wasko notes, studies of the political economy of communication tend to incorporate historical analysis, as "it is essential to document change as well as continuity". ${ }^{73}$ Political economy is also "concerned with power in society", and recognises that it is "distributed very unevenly". ${ }^{74}$ Therefore, it

Economy Alternative to the Neoliberal Theory of the Market and the State (United Nations Research Institute for Social Development, 2001), Wolfgang Streeck. Taking capitalism seriously: Toward an institutionalist approach to contemporary political economy (2010), Kirsten Ford, The Veblenian Roots of Institutional Political Economy (2011).

67 Des Freedman, The Politics of Media Policy (Cambridge: Polity Press, 2008), 1.

68 Ibid., 217.

${ }^{69}$ Oliver Boyd-Barrett, "Theory in Media Research." In Mass Communication Research Methods: Volume 1, edited by Anders Hansen (Los Angeles: Sage, 2009), 5.

70 Vincent Mosco, The Political Economy of Communication (London: Sage, 1996), 25. Emphasis in original.

71 Boyd-Barrett, 33.

72 Boyd-Barrett, 32.

73 Janet Wasko, "The Political Economy of Communications." In Mass Communication Research Methods: Volume 2, edited by Anders Hansen (Los Angeles: Sage, 2008), 9.

74 Boyd-Barrett, 33. 
provides a suitable theoretical approach for this thesis, which is firmly based in historical data, and emphasises the roles of different institutions, with different levels of power and influence, in the censorship process.

The institutional branch of political economy has its origins in the work of Thorstein Veblen in the late nineteenth century, and was based on the importance of "the formative influence of history and culture, and given concrete form through institutions, on the behaviors and preferences of individuals".$^{75}$ However, one of the key problems is defining what an "institution" actually is, as different institutionalist approaches define the term in different ways. Institutions can be defined quite narrowly as formal political and legally defined institutions. For example, B. Guy Peters notes that what he calls "empirical institutionalists" have focused on a "simple dichotomy between presidential and parliamentary governments", a view that shows limited change from early institutionalist approaches which "concentrated on formal-legal definitions of institutions". ${ }^{76}$ However, this thesis takes a broader approach, which goes beyond "formal modes of policy behaviour" and examines other more informal aspects of the censorship process, as it does not just involve formal legal institutions such as the various censorship bodies making legally binding decisions, but various pressure groups and individuals engaging in the process through both legal means such as court cases and appeals of decisions, and other channels such as petitions and letterwriting campaigns.

B. Guy Peters notes that while there are a variety of approaches to institutional theory, there are "some features that do unify the approach". ${ }^{77}$ Those similarities that are relevant to my theoretical approach include the idea "that structures - however defined - do matter"78, that "structures persist while individual members of those structures come and go", and that "structures (institutions) create more regularity of human behaviour than would otherwise exist". ${ }^{79}$ In contrasting institutionalism with liberal and Marxist political economy, Robert Babe notes that "institutionalists rather tend to be

\footnotetext{
${ }^{75}$ Stuart Cunningham and Terry Flew. "Reconsidering Media Economic: From Orthodoxies to Heterodoxies." Media Industries 2, no. 1 (2015): 5.

${ }^{76}$ B. Guy Peters, "Institutional theory: problems and prospects." In Debating institutionalism, edited by Jon Pierre, B. Guy Peters and Gerry Stoker (Manchester: Manchester University Press, 2008), 13.

77 lbid., 5.

78 lbid., 5.

79 lbid., 6.
} 
absorbed in the woof and warp of concrete reality as it unfolds historically, and to view the economy/society as undergoing continual and cumulative change toward an undetermined future". 80 In other words, institutions and their interests, priorities and agency evolve over time.

Instititutionalist political economy also allows for the examination and explanation of "meso-level media practices", and avoids an emphasis on "the assumption of overly uniform or deterministic structural forces" at the expense of examining individual agency. ${ }^{81}$ Such a theoretical approach allows for a balance between what Geoffrey M. Hodgson terms "methodological collectivism" and "methodological individualism" - the former "conflates the individual upon society and thereby lacks an explanation or adequate recognition of how individual purposes or preferences may be changed" 82 , whereas the latter relies on "reductionist claims that structures, institutions or organizations must be analysed largely or wholly in terms of individuals and their properties". 83

Rather than either emphasising theoretical abstraction at the expense of empirical description, or merely providing a chronological listing of a series of censorship decisions, this thesis has attempted to avoid the problem that Robert Post identifies in Foucault's work as well as in what he calls the "new scholarship of censorship" "vertiginous oscillation between extreme abstraction and minute detail", neglecting to properly address "the space between, where most people live most of their lives". ${ }^{84}$ This "space between" is where this thesis is situated, addressing both individual agency and wider institutional influences. As Thompson notes, "[t]he theoretical challenge here is to ground critical political-economic analysis in empirical specifics while linking institutional-level phenomena to macrostructures". ${ }^{85}$ Similarly, Dwayne Winseck argues that "[p]olitical economies of media take it as axiomatic that the media

\footnotetext{
${ }^{80}$ Robert E. Babe, Communication and the transformation of economics: Essays in information, public policy and political economy (Boulder: Westview Press, 1995), 75.

${ }^{81}$ Peter A. Thompson, "Neoliberalism and the political economies of public television policy in New Zealand," Australian Journal of Communication 38, no. 3 (2011): 2.

82 Geoffrey M. Hodgson, "Institutions and Individuals: Interaction and Evolution," Organization Studies 28, no. 1 (2007): 101.

83 lbid., 95.

${ }^{84}$ Robert Post, "Censorship and Silencing," Bulletin of the American Academy of Arts and Sciences 51, no. 5 (1998): 34.

85 Thompson, 2.
} 
must be studied in relation to their place within the broader economic and social context". 86

As this thesis has an empirical focus emphasising institutional decision-making and the way in which the formal powers of the censors are deployed, it is important to try and make sense of the way in which these decisions are made. Thus, the aim is to make sense of the actions of censors on their own terms and view their decisions from their perspective, rather than imposing an outside view on their decision-making process. As Jon Elster argues, rational choice theory emphasises "what we ought to do in order to achieve our aims as well as possible", not "what our aims ought to be". ${ }^{87}$ James $\mathrm{G}$. March notes that rational choice theory is based on the implicit assumption "that actual human choice behaviour in some way or another is likely to make sense", and that "[m]uch theoretical work searches for the intelligence in apparently anomalous human behaviour". ${ }^{88}$ Rational choice theory can be used in a number of ways - as John C. Harsanyi notes, the concept of rationality "is used for explanation, for prediction, and even for mere description of human behaviour". ${ }^{89}$ As this study is an historical one, the focus is not on the prediction of behaviour, but is concerned with the description of historical events, as well as providing an adequate explanation of them in their historical context. March describes a number of different types of rational choice behaviour, such as limited rationality, which examines "the extent to which individuals and groups simplify a decision problem because of the difficulties of anticipating or considering all alternatives and all information"; process rationality, which examines "the extent to which decisions find their sense in attributes of the decision process, rather than attributes of decision outcomes"; and posterior rationality, which examines "the discovery of intentions as an interpretation of action rather than as a prior position". 90 The process of censorship decision-making in the case studies in this thesis shows that there are subtle shifts in the grounding of

\footnotetext{
${ }^{86}$ Dwayne Winseck, "The Political Economies of Media and the Transformation of the Global Media Industries." In The Political Economies and the Transformation of the Global Media Industries, edited by Dwayne Winseck and Dal Yong Jin (London: Bloomsbury Academic, 2011), 4.

87 Jon Elster, "Introduction." In Rational Choice, edited by Jon Elster (Oxford: Basil Blackwell, 1986), 1.

88 James March, "Bounded Rationality, Ambiguity, and the Engineering of Choice." In Rational Choice, edited by Jon Elster (Oxford: Basil Blackwell, 1986), 144.

89 John C. Harsanyi, "Advances in Understanding Rational Behaviour." In Rational Choice, edited by Jon Elster, 83-107 (Oxford: Basil Blackwell, 1986), 83.

90 March, 148-149.
} 
rationalisation, and censorship decisions can be rationalised and explained as being a result of a variety of different types of rational choice behaviour. Some censorship decision-making is also outside the realm of rational choice, and is not "the best means to a given end", but can be explained in terms of social norms, "actions [which] are performed out of habit, tradition, custom or duty". ${ }^{91}$ While Elster notes that such an idea is a "challenge to methodological individualism"92, and James Arnt Aune argues that "[a] typical starting point for discussing rational choice theory is to discuss the notion of methodological individualism"93, I have attempted to strike a balance between the two extremes of methodological individualism and methodological collectivism, both recognising that those involved in censorship decisions have a degree of individual agency, but rejecting the notion that "there do not exist collective desires or collective beliefs". ${ }^{4}$

Another theory which assists in the explanation of the way in which policy decisions are constructed is policy-as-discourse. Sara Shaw describes the concept of policy-asdiscourse as an approach "which seeks to understand and explain the means by which social processes and interactions shape different realities". ${ }^{95}$ Thus, in the case of censorship, the reality of censorship policy and practice is shaped by the discourse around it, since the use of language "sets limits on what can be said", and policy is "inherently ideological". ${ }^{96}$ Policy-as-discourse also rejects the assumption that there are inherent policy problems out there waiting to be solved. As Carol Bacchi argues:

The premise behind a policy-as-discourse approach is that it is inappropriate to see governments as responding to 'problems' that exist 'out there' in the community. Rather 'problems' are 'created' or 'given shape' in the very policy proposals that are offered as 'responses' ${ }^{97}$

\footnotetext{
91 Elster, 23.

92 Ibid., 23.

93 James Arnt Aune, "From Corax to Coase: Rhetoric and Rational Choice Theory." In Communication and the Economy: History, Value and Agency, edited by Joshua S. Hanan and Mark Hayward (New York: Peter Lang, 2014), 98.

94 Elster, 3.

95 Sara E. Shaw, "Reaching the parts that other theories and methods can't reach: How and why a policy-as-discourse approach can inform health-related policy," Health 14, no. 2 (2010): 200. 96 Ibid., 201.

${ }^{97}$ Carol Bacchi, "Policy as Discourse: What does it mean? Where does it get us?" Discourse: studies in the cultural politics of education 21, no. 1 (2000): 48.
} 
Similarly, Philippe Zittoun argues for an emphasis not on "an "objective" notion of change", but on "the way participants define policy and identify change". ${ }^{98}$ Thus, the definition of policy issues and the available responses of policy agents are themselves subject to discursive definition and contestation, and "the importance of policy discourse in framing a political issue" is a key factor. ${ }^{99}$ Des Freedman argues similarly that media policy can be viewed as an area of "ideological legitimation", where "certain ideas are normalized and others problematized". ${ }^{100}$ This approach is methodologically well-suited to the study of film and video censorship through archival material, as it "incorporates qualitative methods to illuminate the processes whereby reality comes into being", and tends to involve the "analysis of multiple 'texts' (such as transcripts from interviews, observations from meetings or historical documents)". ${ }^{101}$ For her own analysis of primary health care research policy, Shaw stresses that "[i]mportance was placed not only on those documents carrying legislative weight or drawing on the official nature of public policy, but also a wider range of documents that enacted the transmission of ideas related to primary care research policy and the potential means for implementing these ideas. ${ }^{102}$ This resulted in analysis of the various sources as "an iterative process exploring across texts: for instance, questioning of interview data led back to original documents and that led back to interviews and other contextual information and so on". ${ }^{103}$

As my research involves a variety of source materials, including official correspondence, informal file notes, and interviews with Chief Censors looking back on their time in the position, Shaw's idea that analysis can be "an iterative process exploring across texts" is particularly relevant. These sources can be seen as "discursive units" which do not provide entire discourses, and groups of such texts can "have a certain coherence and can therefore represent a particular reality of the world". ${ }^{104}$ For example, official correspondence from Ministers and censors during

\footnotetext{
98 Philippe Zittoun, "Understanding Policy Change as a Discursive Problem," Journal of Comparative Policy Analysis: Research and Practice 11, no. 1 (2009): 65.

99 Sarah Maddison and Richard Denniss, An Introduction to Australian Public Policy: Theory and Practice (Cambridge: Cambridge University Press, 2009), 129.

100 Freedman, 3.

101 Shaw, 202.

102 Shaw, 206.

103 Shaw, 207.

104 Shaw, 205, 208.
} 
their time involved in censorship tends to stress the perceived objectivity of the censorship process, whereas other sources such as informal file notes and the Chief Censor's daybooks represent a different set of "discursive units" which in some cases represents a different conception of the nature of censorship. This can create tension when there is a need for a contentious censorship decision to be justified.

While this thesis is not primarily concerned with media effects theory, some aspects can be seen to inform the way in which censors and other historical actors engage with the censorship process. Media effects theory provides a way of understanding how the censors imagined the audience of the material they were classifying, and what perceived impact it might have. Boyd-Barrett identifies media effects, along with political economy, as one of nine "major approaches to the study of mass communications". $105 \mathrm{Jim}$ R. Macnamara provides a summary of some of the key developments in the history of media effects research, noting the evolution of media effects theory from relatively simplistic ideas of an "all-powerful" media to the current emphasis on a "synthesis of views", whereby the media are seen as "influential but through a matrix of factors including audience education, race, sex, religion...access to alternative discourse... [and] diversity of media". ${ }^{106}$ These theories can be linked to the way in which key historical actors conceived of the need for censorship and the potential for harm to be caused by certain films and videos.

Under the umbrella of media effects theory is also the concept of the third-person effect. This was first outlined by W. Phillips Davison in his 1983 article 'The ThirdPerson Effect in Communication'. Davison summarises it in this way:

A person exposed to a persuasive communication in the mass media sees this as having a greater effect on others than on himself or herself. Each individual reasons:

"I will not be influenced, but they (the third persons) may well be persuaded."107

This is a particularly relevant theoretical perspective when addressing the subject of censorship, as those taking the role of the censor (either in an official capacity, or advocating for increased censorship) often stress that certain material does not harm

\footnotetext{
105 Boyd-Barrett, 3-4.

${ }^{106}$ Macnamara, Jim R, Mass Media Effects: A Review of 50 Years of Media Effects Research (CARMAN International Research Paper) (2003), 11.

107 W. Phillips Davison, "The Third-Person Effect in Communication," The Public Opinion Quarterly 47, no. 1 (1983): 1.
} 
them, but may harm others. This can be linked to the notion of the imagined audience that comes into play in the process of censorship. Overall, these different theoretical approaches provide a framework for understanding the diverse decision -making processes at work in the period examined in this thesis.

\section{Film and video censorship in New Zealand - an overview}

Taking into account that New Zealand has its own form of film and video censorship based on state regulation, this section provides a brief history of censorship in New Zealand, with an emphasis on the legislative framework in which film and video censorship operated, as well as changes in censorship practice and the context in which these took place. This allows for the following chapters on film and video censorship during the period 1976 to 1994 to be considered within a wider context of censorship and other historical changes in New Zealand.

During the nineteenth century, official censorship through such avenues as legislation, courts, and customs was limited in its scope. According to Christoffel, colonial New Zealand "was not a tightly regulated society", and while legislation with censorship measures did emerge that "closely followed the example of Britain and the Australian colonies", this was often not until a number of years after the legislation that inspired it. ${ }^{108}$ As Stevan Eldred-Grigg argues, censorship during this time tended to be dominated by that of an unofficial rather than official nature - "[t]he real censors were not the law courts, but the consciences of the respectable", predominantly the "middle classes and colonial gentry". ${ }^{109}$ Customs regulations in 1858 and the Vagrant Act of 1866 included measures placing restrictions on material considered "indecent" or "obscene", although as Chris Watson and Roy Shuker point out, "no attempt was made to define terms like 'obscene' and 'indecent'". 110

\footnotetext{
108 Christoffel, 3.

109 Stevan Eldred-Grigg, Pleasures of the flesh: Sex \& drugs in colonial New Zealand, 1840-1915 (Wellington: Reed, 1984), 3.

110 Watson and Shuker, 116-117.
} 
Eldred-Grigg also notes that early colonial New Zealand was "slow to extend its powers of censorship". 111 Settler society was initially lightly regulated, but as it developed throughout the nineteenth century, "state bureaucracy grew larger and governments became interested in controlling things previously left unregulated". 112 This included some censorship of newspapers by indirect legal means. For example, William Hobson was able to effectively shut down the NZ Advertiser and Bay of Islands Gazette by introducing a "requirement that press proprietors lodge at least two 300 pound deposits", which "was enough" to force the paper to cease publication. ${ }^{113}$

It was not until 1892 that the first piece of legislation "solely for the purposes of censorship" was passed ${ }^{114}$, the Offensive Publications Act. This legislation prohibited publications which were "of an indecent, immoral or obscene nature", and like earlier regulations, left the definition of such terms largely open to interpretation. The law was a "tardy imitation of a British law of 1857 "115, although with one specific measure aimed at particular circumstances of the time. During the 1880s, many "quack cures" were promoted for sexual diseases, both real and imaginary, and which attracted a negative response from articles in the New Zealand Medical Journal. ${ }^{116}$ In response to this, section 5 of the Offensive Publications Act explicitly defined as being "of an indecent nature":

Any advertisement or other publication relating to any venereal or contagious disease affecting the generative organs or functions, or having reference to any nervous debility, or other complaint or infirmity arising from or related to sexual intercourse ${ }^{117}$

Other laws in the early twentieth century extended censorship provisions, although Eldred-Grigg suggests that the arrival of such state censorship "should not be overemphasised", as the laws tended to be copies of British and Australian laws rather

\footnotetext{
111 Eldred-Grigg, 5.

112 Ibid., 120.

113 Jill Ovens and Jim Tucker, "A History of Newspapers in NZ." In Intro: A Beginner's Guide to Professional News Journalism, edited by Jim Tucker (Wellington: New Zealand Journalists Training Organisation, 2004), 24.

114 Christoffel, 6.

115 Eldred-Grigg, 120.

116 Christoffel, 5.

117 Offensive Publications Act 1892, Section 5.
} 
than "bold or novel assumptions of power", and "[m]any gaps remained" such as the lack of theatre censorship. ${ }^{118}$

During the earliest days of cinema, one of those "many gaps" was film censorship. Films were first exhibited in New Zealand at the Auckland Opera House in 1896, less than a year after Auguste and Louis Lumière had held the first screening of films to a paying public audience in Paris. ${ }^{119}$ However, it was not until 1916 that cinema censorship was formalised in legislation, with the Cinematograph-film Censorship Act. While there had been calls for film censorship from various quarters before this Act, the context of the time, with New Zealand heavily involved in World War I, is important here. There had been some limited film censorship regulations allowing the Minister of Defence to prohibit films "representing or purporting to represent" events of the war $^{120}$, and Lisa Cutfield suggests that the combination of censorship lobbying and being at war may have "created an image of moral consensus on the cinema question". ${ }^{121}$ Similarly, Simon Sigley notes that the provisions of the new legislation "were in some measure due to the anxieties generated" by the war. ${ }^{122}$ Unlike laws regarding "indecent" and "obscene" print publications, the 1916 Act placed the point of official censorship intervention earlier, before any film was to be publicly exhibited. Section 2 stated that "it shall not be lawful to exhibit any cinematograph-film" unless it had been approved by the officially appointed film censor. The censor was empowered to ban films by Section 4(3) of the Act, which stated that approval for public exhibition would not be given

in the case of any film which, in the opinion of the censor, depicts any matter that is against public order and decency, or the exhibition of which for any other reason is, in the opinion of the censor, undesirable in the public interest. ${ }^{123}$

As Paul Christoffel notes, both the phrases "in the opinion of the censor" and "undesirable in the public interest" were "sweeping" and gave the censor a large amount of individual discretion. ${ }^{124}$ George Warren Russell, the Minister of Internal

\footnotetext{
118 Eldred-Grigg, 121.

119 Watson and Shuker, 28.

120 Cutfield, 27.

121 Ibid., 28.

122 Sigley, 2013, 204.

${ }^{123}$ Cinematograph-film Censorship Act 1916, Section 4(3).

${ }^{124}$ Christoffel, 12.
} 
Affairs, argued at the time that the clause regarding films "undesirable in the public interest" was partly aimed at films which could be detrimental to recruiting during a time of war, and other films "which do not involve matters of public order and decency, but which may be very questionable in their effect upon the public mind". ${ }^{125}$ The use of the phrase "for any other reason" also left the legislation open to broad individual interpretation, in contrast with later legislation which has tended to more specifically identify issues which the censor should consider. The Act also gave the censor the ability to either pass a film as suitable for anyone to view ("[s]uch approval may be given generally"), or "subject to a condition that a film be exhibited to any specified class or classes of persons". ${ }^{126}$ While this gave room for restriction of certain films to adult audiences, this kind of classification did not become common until the 1950s Christoffel notes that "[a]ge restrictions such as R16 appear to have been used on occasions during the 1930s, but those who advocated for their use as standard policy were invariably told it was up to parents to police their children's viewing habits". ${ }^{127}$ Both the censorship of films prior to exhibition and what Watson and Shuker call the "discretionary clause" proved to be long-lasting legacies of this first piece of film censorship legislation - the "discretionary clause" remained until 1976, and to this day films must be classified and approved before public exhibition. ${ }^{128}$

After the passage of the 1916 censorship act, New Zealand's first ever Chief Censor was appointed. William Jolliffe, a barrister described by the Minister of Internal Affairs as a "clean average man" whose job was "protecting the public mind" 129 , was the sole official involved in censoring films, and he served until 1927. Early annual reports on film censorship were brief and give little detail of the censorship process, although the 1917 report suggests that there was a desire for legislation "to provide for the censorship of posters advertising films". ${ }^{130}$ The teachers' union, the New Zealand Educational Institute, became one of the most important pro-censorship voices at this time, as it "adopted as its exclusive concern all matters perceived to affect the interest and education of New Zealand youth", including the perceived negative impact of the

\footnotetext{
125 Cutfield, 29.

126 Cinematograph-film Censorship Act 1916, Section 4(4).

127 Christoffel, 27.

${ }^{128}$ Watson and Shuker, 51.

129 Cutfield, 30.

${ }^{130}$ ACGO IA83 20 - Annual Report - New Zealand Censor 1917-1941.
} 
cinema. ${ }^{131}$ During the 1920 s, issues such as "the influence of crime pictures, and the cinema as a source of subversion" remained prominent. ${ }^{132}$ However, "nationalistic sentiments and imperial concerns" became more important, and pro-censorship campaigners "associated their own interests with the future of the New Zealand nation". ${ }^{133}$

The 1916 Act, which was a mere two pages long, was replaced in 1928 by a much more detailed Cinematograph Films Act. This Act gave room for the censor to cut a film, rather than simply to approve it or ban it outright. Section 5(2) of the Act stated:

On the completion of the examination of any film, the Censor -

(a) May approve the same for exhibition as aforesaid; or

(b) May refuse to approve the same; or

(c) May agree to approve the same subject to such excisions from the film as he thinks proper ${ }^{134}$ Again, the legislation gave room for much individual discretion, through the wording "as he thinks proper". Reflecting the arrival of "talkies" in the late 1920s, the Act instructed the censor to take sound into account. While section 4 of the Act retained the measures surrounding "public order and decency" from the 1916 Act, as well as the "discretionary clause" that gave the Chief Censor wide-ranging power to ban films, it also added that if a film

is intended to be accompanied by a mechanical reproduction of sound (whether or not the device or arrangement for such reproduction is an integral part of the film), the censor may take such reproduction of sound into consideration in determining whether or not the film should be approved, or in determining what excisions, if any, should be made therefrom. ${ }^{135}$

Concern over advertising material for films also seems to have been heeded, as a new clause allowed the censor to "require the censorship of and to regulate the exhibition of posters and other advertising matter used or intended to be used in relation to any cinematograph-film or films". An amendment in 1934 introduced the concept of advisory ratings for films, allowing the censor to pass films unrestricted but "with a recommendation to the effect that the film is unsuitable for exhibition to children", or

\footnotetext{
131 Cutfield, 36.

132 Ibid., 48.

133 lbid., 48.

134 Offensive Publications Act 1892, Section 5(2).

135 Cinematograph Films Act 1928, Section 5(4).
} 
"with a recommendation to the effect that the film is suitable for exhibition to adult audiences only". ${ }^{136}$

During the 1930s, there was a continued concern regarding foreign (or rather nonBritish) influence on the part of supporters of greater censorship. As Simon Sigley notes, "woven into the cultural fabric of 1930s New Zealand was a xenophobic temperament and suspicion of difference". ${ }^{137}$ For example, a petition in 1935 from 77 churches and social organisations requested that "All films that had their origin in Russia should be banned from the screens in New Zealand". ${ }^{138}$ New Zealand film censorship remained essentially conservative in nature throughout the 1930s and 1940s. However, despite limited change in actual censorship legislation, significant change in censorship practice occurred after Gordon Mirams was appointed as Chief Censor in 1949. Mirams was the first Chief Censor "to have any obvious interest in films"139, having previously been a film critic and one of the founders of the Wellington Film Society. ${ }^{140}$ Watson and Shuker note that he was liberal and forward thinking for his era, hoping that 'screen education' would one day be taught at schools. ${ }^{141}$ However, this was coupled with a degree of elitism, as he tended to pass films regarded as 'art films' while banning "popular films marketed for a juvenile audience" such as The Wild One (1953). ${ }^{142}$ Mirams introduced a new policy of giving age restrictions such as R16, something which had been allowed for since the first film censorship Act in 1916. Mirams initially took a cautious approach, writing in 1950 after the classification of the film No Room at the Inn (1948) that such a policy was "to be tested with this type of film"143, but he eventually "made extensive use" of such classifications, and this allowed film censorship in New Zealand to be "far more liberal" than that in Australia, where such certificates were not introduced until 1971. ${ }^{144}$

Things were to change again with the appointment of a new Chief Censor, Doug Mclntosh, in 1960. Mclntosh spent most of his time as Chief Censor operating under

\footnotetext{
${ }^{136}$ Cinematograph Films Amendment Act 1934, Section 2.

137 Sigley, 2008, 198.

138 Ibid., 198.

139 Christoffel, 27.

140 Watson and Shuker, 42.

141 Ibid., 42.

142 Ibid., 42.

${ }_{143}$ ACGO IA1W2578 114 - Censorship - Forms - General File 1916-1951.

${ }^{144}$ Watson and Shuker, 46
} 
the 1961 Cinematograph Films Act, the purpose of which was "primarily to consolidate the existing regulations" rather than to introduce any fundamental change to the nature of film censorship. ${ }^{145}$ Indeed, this Act retained "provisions descended directly (and largely intact)" from New Zealand's very first film censorship legislation in $1916^{146}$, thus preserving the "discretionary clause", and even still containing the clause regarding the "mechanical reproduction of sound" introduced in the 1928 Act. ${ }^{147}$ One of the most significant problems resulting from the "discretionary clause" in film censorship legislation prior to 1976 was the lack of clarity and consistency in censorship decisions, since the Chief Censor was not obliged to give detailed reasons for his decisions. Even looking back now, with the ability to access archival material such as the Chief Censor's daybooks that were not available to the public at the time, the reasons for some decisions are difficult to decipher. For example, the original version of Cape Fear (1962) was banned in 1974 after having also previously been banned in 1962 and 1969, but the 1974 daybook has detailed notes on the content of the film without any reason for the decision being clear, and the official notice of the film's ban simply makes the standard statement "[t]hat the film depicts matter that is contrary to public decency and its exhibition is undesirable in the public interest". ${ }^{148}$ In contrast to Mirams, Mclntosh was less evidently supportive of 'art films', and "was criticised for banning and cutting films of serious intent". ${ }^{149}$ Watson and Shuker similarly suggest that McIntosh faced criticism because "he frequently cut films instead of giving them the restrictive certificates pioneered by Mirams". ${ }^{150}$ However, changes in film content, especially in the 1970s, may also explain Mclntosh's more restrictive approach. As Simon Sigley argues, "Hollywood films were no longer the 'safe' family entertainment of yore"151, and European arthouse films were even more explicit in their content. While Christoffel argues that McIntosh "appears to have heeded the criticism, and to have become more liberal" during the 1960 s $^{152}$, the 1970 s saw a huge upswing in the number of films being banned outright. From 1 April 1962, when the 1961 Act came

\footnotetext{
145 Christoffel, 28.

146 Sigley, 2013, 204.

147 Cinematograph Films Act 1961, Section 14(2).

148 ADNB W5848 23133 Box 20 - Refusal of Censor to approve Film 1973-1975.

149 Christoffel, 28.

150 Watson and Shuker, 46.

151 Sigley, 2013, 202.

152 Christoffel, 28.
} 
into force, until 31 December 1969, less than 20 feature films were banned, and the Films Censorship Board of Review only banned one, upholding the Chief Censor's ban of Roger Corman's The Wild Angels (1966). From 1 January 1970 until 1 April 1977, when the 1976 Act came into force, approximately 150 feature films were banned in New Zealand, and the Board of Review upheld over 20 of these bans. ${ }^{153}$ The films banned were extremely eclectic, including arthouse fare such as La Grande Bouffe (1973) and WR: Mysteries of the Organism (1971), blaxploitation action films such as Foxy Brown (1974) and Truck Turner (1974), concert films such as Good to See You Again, Alice Cooper (1974) and Frank Zappa's 200 Motels (1971), and Australian comedy The Adventures of Barry McKenzie (1972). There was even explicitly political censorship. In July 1974, the United Nations Association wrote to McIntosh querying his ban of Night Over China, a Soviet propaganda film critical of Maoist rule in China, and while they noted that he was "not obliged to give reasons for [his] decisions", they hoped that "there should not be any suspicion of political factors entering into the decision". However, McIntosh replied:

As you are aware the Peoples [sic] Republic of China was officially recognized by New Zealand on $26^{\text {th }}$ December, 1972 and when the film was examined [on 28 February 1973] the New Zealand Government was proceeding to establish an embassy in China. In my opinion it was not in the national or public interest to approve a film containing so many derogatory and provocative references to the head of the Chinese state. ${ }^{154}$

McIntosh did recognise in the 1970s that the 1961 Act was outdated and had not kept pace with societal change, writing in response to a letter from a member of the public in 1976:

[The 1961 Act] does not appear to be adequate for modern conditions and is very restrictive in its scope, especially from the point of view of the censor who must administer the Act in terms of the existing law. This is particularly difficult in view of the fact that all cinemas are public places in terms of the Act and the censor must take into account the Common Law or current decisions in respect of public decency etc. ${ }^{155}$

\footnotetext{
153 Data sourced from Office of Film and Literature Classification online database, http://www.classificationoffice.govt.nz/DDA/Pages/Screens/DDA/WelcomePage.aspx. ${ }^{154}$ AAAC W4303 Box 5 - Miscellaneous Enquiries, General Enquiries re Censorship from Public 1968-1978.

155 AAAC W3628 Box 1 - Correspondence to Film Censor 1967-1982.
} 
McIntosh's interpretation of the idea of cinemas as a "public place" perhaps goes some way to explaining his extremely restrictive censorship, especially in the 1970s. In response to a letter regarding the classification of Alan J. Pakula's film All the President's Men (1976), McIntosh noted that it had been rated R16 "because of the language used", and that "[u]nder our law a cinema is a public place and language must be considered in respect to its use in public places". ${ }^{156}$

While a variety of changes in film censorship practice had occurred since the original 1916 Act, the fact that the fundamental legislative principles under which such censorship operated had remained largely unaltered suggests that any significant shifts were largely the result of individual agency and institutional culture. However, 1976 saw the passage of the Cinematograph Films Act, which represented a fundamental legislative shift in the way film censorship was to be approached. This Act removed the "discretionary clause", and introduced the concept of films being "injurious to the public good" as a reason for them to be banned or cut, and gave the censor guidelines on what kinds of material could be considered "injurious". ${ }^{157}$ As Christoffel notes, this new law represented "more liberal film censorship". 158 The Act listed a number of factors for the censor to consider in making the determination of whether a film was "injurious to the public good", including "the dominant effect of the film as a whole, and its likely effect on the audience likely to view the film", the artistic merit of the film, the "extent and degree" to which it treats violence, crime, cruelty and the like, and how far the film denigrates "any particular class of the general public", such as ethnic or religious groups. ${ }^{159}$

The 1976 Act was replaced in 1983 with the Films Act, which preserved the test of whether films were to be considered "injurious to the public good", and was similar to the 1976 Act in many respects. One important difference is noted by Watson and Shuker: the clause requiring the censor take into account the "likely effect on the audience likely to view the film" was removed, although the requirement to consider "the dominant effect of the film as a whole" was retained ${ }^{160}$ However, while this Act is only briefly discussed by Watson and Shuker, and mentioned only in passing by

\footnotetext{
156 Ibid.

157 Watson \& Shuker, 51-52.

158 Christoffel, 34.

159 Cinematograph Films Act 1976, Section 26(2).

160 Watson and Shuker, 53.
} 
Christoffel as the "successor" to the 1976 Act $^{161}$, it did introduce some other significant changes, and attracted negative attention from pro-censorship campaigners as it was seen by them as lessening censorship restrictions. Minister of Internal Affairs Allan Highet argued that the Act was intended to "streamline the censorship process and to correct anomalies" in the 1976 legislation, further noting that it "allowed the Chief Censor to concentrate on those films that are likely to be regarded as controversial rather than spending time on films, such as on training, which are known to be innocuous". ${ }^{162}$ To this end, a number of types of film were exempted from approval before public exhibition, including "personnel training and development" films, "natural history films", "scientific films", and films of sporting events. ${ }^{163}$ Other significant changes included those regarding the exhibition of restricted films to children, changes which Highet considered gave the Chief Censor "a little more flexibility", but which were characterised by the Society for the Promotion of Community Standards as a "Sodom and Gomorrah Bill" which breached the United Nations Declaration of the Rights of the Child by "leaving children open to corruption". ${ }^{164}$ The changes introduced were "RP" certificates such as "RP13 and "RP16", which restricted films to those over a certain age unless they were accompanied by a parent or guardian, and the ability of the film censors to vary a restrictive certificate in special circumstances, which Highet noted "may include a school class studying a novel for which there is a restricted feature". ${ }^{165}$

While home video had emerged in New Zealand by the early 1980s, it was not covered by existing film censorship legislation unless a video was submitted to the censor for the ostensible purpose of public exhibition, and as in the United Kingdom, some videos were seized by customs as "indecent". Censorship legislation explicitly addressing home video did not emerge until the Video Recordings Act of 1987. This set up a twotiered system of classification through two new bodies, the Video Labelling Body and the Video Recordings Authority. The creation of the Labelling Body resulted from a focus on providing "consumer information" rather than restrictive ratings - it was an industry body that could only provide indicative classifications such as " 13 " and "16",

\footnotetext{
161 Christoffel, 37.

162 AAAC 7536 W5169 Box 13 - Films Bill 1983 - General Correspondence 1983-1989.

163 Films Act 1983, Section 9(1).

164 AAAC 7536 W5169 Box 13 - Films Bill 1983 - General Correspondence 1983-1989.

165 lbid.
} 
rather than censorship ratings with legal force, based on previous decisions by the New Zealand film censor or censors overseas. In practice, this often meant that cinema films with restrictive R13 or R16 rating ended up with a purely advisory "13" or "16" rating in video form. In a 1989 letter in response to a query about the availability of "adult movies" on video, Minister of Internal Affairs Michael Bassett stressed that the purpose of labelling under the 1987 Act was "to provide consumer information about the content of videos", and that while he was concerned about crime and violence, "conclusive evidence of a causal link between crime and the visual media has yet to be found". However, he did note the power of the Video Recordings Authority to "classify videos of a restricted nature or those which may be indecent", which was the other part of the two-tiered system. ${ }^{166}$ The Video Recordings Authority used the same test of whether or not a video could be considered "injurious to the public good", although they used the somewhat loaded term "indecent" to describe such videos, rather than "refused classification", which was used for films. Videos could be referred to the Video Recordings Authority by the Labelling Body if it was "having substantial difficulty determining the appropriate rating" 167 , or if the video could be "considered potentially 'indecent". 168 The Video Recordings Act Amendment 1990 closed the "loophole" that allowed films rated by the Film Censor as R16 to be only "16" on video, requiring that films "classified under section 15(1) of the Films Act 1983 as being approved for exhibition only to persons of or over a specified age (the specified age being an age that is 16 years or more)" be submitted to the Video Recordings Authority. ${ }^{169}$

In 1993, the Films, Videos, and Publications Classification Act was passed. This represented another fundamental change in New Zealand censorship legislation, bringing together censorship of film, video and other publications, while retaining the concept of "injurious to the public good" and extending it to cover media other than film and video. Rather than "indecent" as in the prior case of banned video recordings, banned media under the new act was deemed to be "objectionable". The Films Act 1983, Indecent Publications Act 1963 and Video Recordings Act 1987 were all repealed, and responsibilities of the office of the Chief Censor of Films, the Video

\footnotetext{
166 AAAC 7536 W5169 Box 5 - Ministerial Correspondence 1985-1989.

167 Video Recordings Act 1987, Section 15(2).

168 Watson and Shuker, 70.

169 Video Recordings Act Amendment 1990, Section 2(3).
} 
Recordings Authority, and Indecent Publications Tribunal were given to a single new body, the Office of Film and Literature Classification. The confusion created by having multiple censorship bodies was eliminated to some extent, particularly the problem of having separate film and video censors who sometimes came to different decisions on the same film. This legislative change arguably restricted the individual discretion of censors even further, for the first time specifying types of material that were to be banned. Watson and Shuker note that this was "attacked by liberals as a 'shopping list"'170, while Diana Gardner suggests that it constituted an "instantly bannable content clause", with no room to consider context or artistic merit. ${ }^{171}$ With one amendment in 2005, this is the legislation under which film and video censorship in New Zealand operates today.

\section{Chapter summary}

This chapter has outlined how this thesis is positioned within existing academic literature, both theoretically and empirically, as well as placing the time period of 1976 to 1994 within the wider context of New Zealand censorship history as a whole. By taking an institutionalist political economy approach, and going into greater depth into censorship in this period than previous studies with an emphasis on extensive archival research, this thesis represents a significant contribution to scholarship on censorship in New Zealand. The following chapter explains the methodological approach in depth, outlining the types of data collected, their strengths and limitations, and the way in which the data has been analysed to provide an account of film and video censorship in New Zealand from 1976 to 1994 through significant case studies.

\footnotetext{
170 Watson and Shuker, 58.

171 Gardner, 21.
} 


\section{Chapter Two: Methodology and Data Collection}

\section{Chapter overview}

As Nigel King and Christine Horrocks argue, epistemology, or "how we know what we know", is something that is "central to any methodological approach", and thus this methodology is guided by assumptions inherent in an institutionalist political economy theoretical approach. ${ }^{1}$ This provides what Stefanos Mantzoukas describes as "the rules by which [researchers] have agreed to play and against which they should be judged". ${ }^{2}$ This thesis examines the institutional decision-making process, which evolves in response to various factors including technology, social mores and the censors' institutional context. This is addressed through the following questions:

1. What continuities and changes were there in the way in which film and video censorship was practiced and rationalised in New Zealand during the period from 1976 to 1994 ?

2. How can such continuities and changes be explained in terms of individual agency, institutional pressures, legal requirements, and other factors?

In order to answer these questions, records and memories of institutional agency, values and rationalisation are needed. This chapter explains how the data for this thesis was collected and then analysed and triangulated to produce an account of film and video censorship in New Zealand from 1976 to 1994. Part of this analytical process involved the development of a typology of modes of censorship rationalisation, which arose from initial analysis of the data, and fed back into further analysis as a means by which to explain the variety of ways in which key censorship decisions were explained and justified.

\footnotetext{
${ }^{1}$ Nigel King and Christine Horrocks, Interviews in Qualitative Research (Los Angeles: Sage, 2010), 8. 2 Stefanos Mantzoukas, "Issues of Representation within Qualitative Inquiry." In Qualitative Research 2: Volume 3, edited by Alan Bryman (Los Angeles: SAGE Publications, 2007), 15.
} 


\section{Data collection}

The data collected for this thesis largely consists of pre-existing historical material, including archival material from Archives New Zealand and the Alexander Turnbull Library, as well as media material such as newspaper articles. However, this is complemented by interviews with two former Chief Censors, Arthur Everard and Jane Wrightson, as well as with then current Chief Censor, Andrew Jack. ${ }^{3}$ This material has allowed for the construction of an historical narrative of evolving institutional rationales, values and priorities, and an examination of the discourse that existed around the subject of censorship during the period from 1976 to 1994. However, as the focus has been on the censorship history of particular films as case studies, these are the subject of some limited textual analysis in order to compare the films as texts with the historical discourse about them, since there is often a significant difference between what was said about these films and their actual content, especially on the part of advocates for stricter censorship.

\section{Archival material}

This thesis centres on archival material, in particular that held by the main office of Archives New Zealand in Wellington. As Deacon, et al (2009) suggest, use of documentary sources can be either "to supplement the material we have collected ourselves...or we can make them the primary focus of our research". ${ }^{4}$ The emphasis for this study is on the latter approach. Archives New Zealand holds an extensive amount of material covering film and video censorship in the period I have examined, although I also made contact with the Office of Film and Literature Classification during the early planning stages for information and advice. As well as the material from

\footnotetext{
${ }^{3}$ Andrew Jack was interviewed in November 2015, and was succeeded by David Shanks in May 2017.

${ }^{4}$ David Deacon et al, "Dealing with Documentation." In Mass Communication Research Methods: Volume 4, edited by Anders Hansen (Los Angeles: Sage, 2009), 282.
} 
Archives New Zealand, I have also collected a material from the Alexander Turnbull Library, including newsletters of the Society for the Promotion of Community Standards.

The material held in Archives New Zealand covers a variety of agencies responsible for film and video censorship in the period from 1976 to 1994, including the Film Censor's Office, the Video Recordings Authority, and the Cinematograph Films Board of Review. Among this material is correspondence to the Chief Censor and other key officials from various organisations interested in the subject of censorship, such as the Society for the Promotion of Community Standards and Women Against Pornography, as well as a wide range of individuals. There are also files on specific films identified under the heading "Controversial/Interesting and Some Rejected Films", which include correspondence from members of the public as well as between censors and politicians, as well as daybooks which include notes taken while films were being examined by the censors.

When assessing the value of written documentation as a source, and what "you can and cannot say on the basis of your sources", there are some significant issues to take into account. ${ }^{5}$ Deacon et al identify this as "questions of evidence", and emphasise the degree of authenticity, credibility and representativeness. ${ }^{6}$ Scott notes that authenticity relates to a document's "genuineness: whether it is actually what it purports to be". ${ }^{7}$ Since an inauthentic or "unsound" document can be viewed as one which "is not close enough to the original because it has been corrupted in various ways" ${ }^{8}$, the fact that the documents used for this thesis are original documents created by the participants in the historical events, and are archived as an official record of agencies of the state involved in censorship, attests to their authenticity. Credibility refers to the degree in which "an observer is sincere in the choice of a point of view and in the attempt to record an accurate account from that chosen viewpoint". 9 The issue of representativeness involves "a judgement as to whether the documents consulted are representative of the totality of relevant documents", and if any are to be considered

\footnotetext{
5 lbid., 297.

6 lbid., 288.

7 John Scott, A Matter of Record (Cambridge: Polity Press, 1990), 20.

8 Ibid., 20.

9 Ibid., 22.
} 
unrepresentative, "to what extent and in what respects those documents are unrepresentative". ${ }^{10}$

Beyond these considerations, it is also essential to assess the deeper "question of meaning", which Deacon et al suggests may seem "straightforward enough", but simply looking at "what a document is about...does not delve below the surface to explore implicit meanings". ${ }^{11}$ As John Scott notes, archival material such as this is not "merely neutral reports of events", but such documents are "shaped by the political context in which they were produced and by the cultural and ideological assumptions that lie behind it". ${ }^{12}$ The archival material on film and video censorship does cover a wide range of perspectives on censorship from a variety of historical actors, thus providing a sense of both the way in which censorship was practiced by those charged with engaging in it in an official capacity, and the wider discourse around the subject of censorship itself. As Gary McCulloch writes in his discussion of official archives:

They contain, as one would expect, a great deal of material directly related to administration and policy, involving the general maintenance of affairs as well as the day-to-day discussion of issues and problems. However, they include not only committee papers and memoranda but also letters from the public, records of interviews with interest groups, clippings from newspaper reports and notes on particular institutions. That is to say, not only are they relevant to public or official concerns at a national level, but they may also be highly significant for research on communities, neighbourhoods, institutions, families and individuals. ${ }^{13}$

The archival material which I have collected for this thesis was photographed and organised into folders based on the original archival files from which each document came, providing a large collection of material on film and video censorship in general, and the specific films selected for the case studies. However, this material was not always filed in the most obvious place - for example, some documents were misfiled, and the date ranges for some files were not always accurate. Thus, it was sometimes necessary to cast the net wider when trying to locate particular documents. Finding a certain document would sometimes lead directly to others - for example, chains of correspondence sometimes had to be traced over multiple archives files in order to

\footnotetext{
10 lbid., 24.

11 Deacon et al, 288.

12 Scott, 60.

${ }^{13}$ Gary McCulloch, Documentary Research in Education, History and the Social Sciences (London: RoutledgeFalmer, 2004), 53.
} 
get the full context of what was being discussed. The Chief Censor's daybooks provided their own problems. While the classification date of a particular film provided a starting point for finding the censor's notes on each individual film, the contents of each daybook were not clearly indexed, and several daybooks often covered the same period, so finding an individual film was not always straightforward. The daybooks also contained notes that could not have been anticipated by simply following classification dates, such as preliminary examinations by the censors that did not result in a formal classification. Therefore, going through the daybooks fully rather than simply following up individual film classifications provided additional useful information. Daybook notes were taken either by the Chief Censor or one of the two Deputy Chief Censors, and while they were sometimes initialled by the person taking the notes, this was not always the case. Therefore, it was sometimes necessary to use examples of handwriting clearly identified as being by a particular censor in order to ascertain who had taken the notes. This was important as the daybook notes not only contain descriptive information about a film which was used to aid in making a classification decision, but sometimes also include subjective value judgements about the film, or other more opinionated information, which need to be correctly attributed.

\section{Newspapers}

Newspapers also provided a valuable source of material on attitudes to film and video censorship expressed in public discourse, although media coverage of censorship is not a major focus of this thesis. Many of the files in Archives New Zealand include clippings from newspapers on censorship issues, and from my contact with the Office of Film and Literature Classification, I was provided with a document which catalogues the Chief Censor's press clippings collection, which is in the process of being transferred to Archives New Zealand. Other newspaper material has been sourced from microfilm copies held in the Alexander Turnbull Library. Newspaper coverage has provided some information not present in the archival sources, as well as highlighting the contrast between the way censorship decision-making occurred as recorded in the archives and the way it was presented in the media. However, as an account of events from the perspective of reporters, rather than a first-hand account from those directly 
involved in censorship, newspaper reports do need to be treated with a greater deal of caution as a record of events.

\section{Interviews}

While I have primarily used pre-existing historical data for this thesis, this has been complemented by interviews with former Chief Censors Arthur Everard and Jane Wrightson, who served from 1983 to 1990 and 1990 to 1994 respectively, and then current Chief Censor Andrew Jack. These interviews were approved by Victoria University's Human Ethics Committee, and I gained informed consent in writing from all interviewees, recorded the interviews, and kept the data secure. These were semistructured and open-ended interviews, with some pre-prepared questions, that focused upon censorship policy and practice. ${ }^{14}$ As Niranjala Weerakkody notes, while semi-structured interviews do have a set of pre-determined questions, they also give the interviewer "the freedom and flexibility to add other questions or vary the wording or order of the questions posed from the list, if the respondent's unique characteristics or circumstances make it necessary or useful". ${ }^{15}$ Since each Chief Censor has faced different decisions and different individual circumstances, it was necessary to allow for such flexibility based on their answers to the pre-prepared questions.

Using interviews in addition to documentary sources provides for a more reliable account through triangulation - as Deacon et al note, "[j]ust as a surveyor takes measurements from a number of vantage points to fix the 'true' position of a particular point on the ground, so researchers check the full range of available sources to build up the most accurate and comprehensive account possible". ${ }^{16}$ Interview material has helped to ensure the validity of my interpretations of the effects of contextual factors on censorship decisions which I have made based on documentary sources. However, triangulation between archival material and interviews can reveal inconsistencies which require nuanced interpretation, and not simply the privileging of one source over

\footnotetext{
${ }^{14}$ The question schedules, information sheet and consent form are included as an Appendix.

${ }^{15}$ Niranjala Weerakkody, Research Methods for Media and Communications, 2nd ed. (Melbourne:

Oxford University Press, 2015), 187.

${ }^{16}$ Deacon et al, 301.
} 
another. While the archival sources can provide more accurate information about very specific details which the interviewees may not always remember perfectly, the interviews provide a sense of reflection and overall understanding of the interviewees' role as censors that is not always present in the day-to-day minutiae of the censorship process recorded in the archival material. As Lucas and Strain argue, "old memories may be more valuable because they are distant from the concerns of the present or the immediate past", and interviews can "reveal inconsistencies, gaps and silences to produce a more candid view than some written records can supply". ${ }^{17}$ In the case of film censors, the lack of an immediate need to defend and justify decisions in an interview conducted a number of years after they were made can result in a sense of reflection and self-analysis not evident in the documentary sources. Similarly, Taylor, Bogdan and DeVault argue the act of being interviewed itself creates a new perspective on the part of the interviewee:

By virtue of being interviewed, people develop new insights and understanding of their experiences. They may not have thought about or reflected on events in which the interviewer is interested, and even if they have, they interpret things a bit differently each time. ${ }^{18}$

Interviews have sometimes been criticised as a source of data due to their perceived selectivity and potentially artificial nature, with some social scientists making "increasing reference to the distinction between "naturally occurring," "natural," or "naturalistic" data as opposed to "contrived" or "nonnaturally occurring" data" such as interviews. ${ }^{19}$ However, even if pre-existing data which has not been created by the researcher is used, issues of "editing, selection, distortion and omission" are still very much relevant, even in the case of so-called "naturally occurring" data such as archival documents. Thus, interviews provide a valuable way in which to provide a fuller picture than archival material alone can do.

\footnotetext{
${ }^{17}$ Brad E. Lucas and Margaret M. Strain, "Keeping the Conversation Going: The Archive Thrives on Interviews and Oral History. In Working in the Archives: Practical Research Methods for Rhetoric and Composition, edited by Alexis E. Ramset et al (Carbondale: Southern Illinois University Press, 2010), '260-261.

${ }^{18}$ Steven J. Taylor, Robert Bogdan and Marjorie L. DeVault, Introduction to Qualitative Research Methods: A Guidebook and Resource, 4th Ed (Hoboken: Wiley, 2016), 114.

${ }^{19}$ Pirjo Nikander, "Interviews as Discourse Data." In The SAGE Handbook of Interview Research: The Complexity of the Craft, edited by Jaber F. Gubrium et al (Thousand Oaks: SAGE Publications, 2014).
} 


\section{Film case studies}

Rather than attempting to provide an absolutely comprehensive account of film and video censorship during the period from 1976 to 1994, I have used case studies of films that can provide particular insights into the practice of censorship in New Zealand. As John Corner (2009) notes, despite the potential "hazards of unrepresentativeness", focusing on case studies provides a "way of getting across both the elements of historical change and of historical context, producing a more comprehensive yet dynamic sense of past conjunctures". ${ }^{20}$ Focusing on a small number of individual films allows for a level of depth and detail not possible if attempting a broader historical survey, while still allowing for examination of continuity and change in the practice of censorship. The selection of which films to examine as case studies has arisen from my collection and analysis of archival material, and is based on several key criteria. One of these is the level of controversy which the film created, either in New Zealand specifically, or both in New Zealand and in other countries. Films that are passed by the censor uncontroversially (such as G-rated children's films) or banned with little comment or discussion (such as violent pornography) do not reveal as much about the process of censorship, and the way in which censorship is a site for contested discursive legitimacy, as films where the censor's decision is contentious and subject to debate and discussion. Such controversy manifested itself in the reception of these films, both before and after their release, and this is evidenced in sources such as correspondence to the Chief Censor, government ministers, and Members of Parliament, media coverage, and the records of organisations such as Women Against Pornography and the Society for the Promotion of Community Standards. Films which were controversial in New Zealand but did not generate a significant amount of evidence of controversy elsewhere in the world provide insights into the ways in which film and video censorship practice in New Zealand was unique to this country. One notable example is George Miller's 1979 film Mad Max, which was initially banned in New Zealand, and not released here until after the 1981 sequel, largely as the result of concerns about gang violence. I have also

\footnotetext{
20 John Corner, "Finding Data, Reading Patterns, Telling Stories: Issues in the Historiography of Television." In Mass Communication Research Methods: Volume 1, edited by Anders Hansen (Los Angeles: Sage, 2009), 247.
} 
included case studies of two New Zealand films, Angel Mine and Goodbye Pork Pie, for which there is evidence of censorship considerations playing a significant role in the actual filmmaking process itself. The film case studies examined are Bernardo Bertolucci's Last Tango in Paris (1972), George Miller's Mad Max (1979), Terry Jones's Life of Brian (1979), David Blyth's Angel Mine (1978), Geoff Murphy's Goodbye Pork Pie (1980), Meir Zarchi's I Spit on Your Grave (1978), Abel Ferrara's The Driller Killer (1979), Jean-Luc Godard's Hail Mary (1985), Martin Scorsese's The Last Temptation of Christ (1988), John McNaughton's Henry: Portrait of a Serial Killer (1986), and Pier Paulo Pasolini's Salò, or the 120 Days of Sodom (1975). While not strictly a film in the same sense as these examples, I have also looked at a short compilation video of material from so-called "video nasties" which the Society for the Promotion of Community Standards attempted to screen to Members of Parliament in an effort to sway them towards passing strict video censorship legislation. The amount of available data on each film varies, therefore some case studies are examined in greater depth than others.

\section{Approach to data analysis}

This data has been brought together and analysed to provide both a narrative account of film and video censorship in New Zealand between 1976 and 1994, and an analysis of censorship involving various historical actors and institutions. As John Corner argues in his discussion of the historiography of television, "[c]ollections of data largely hold value to the extent that they can be turned into evidence within an account of significant circumstances and their interconnections, including causal links" ${ }^{21}$, and the value of the data collected for this thesis is that it has allowed for an extremely detailed and largely first-hand account of censorship. In their account of censorship in New Zealand published in 1998, Watson and Shuker note when discussing video censorship that they "have quoted Libby Hogg [one of the video censors] at some length because such insider accounts of the censorship process are relatively rare". ${ }^{22}$

\footnotetext{
${ }^{21}$ Ibid., 242.

${ }^{22}$ Chris Watson and Roy Shuker, In the Public Good? Censorship in New Zealand (Palmerston North: The Dunmore Press, 1998), 73.
} 
However, the current availability of archival material covering film and video censorship during the period from 1976 to 1994 has meant that it has been possible to tell the story of such censorship primarily from "insider accounts", a fact which distinguishes this thesis from previous studies which cover the same period. Bringing together all of the archival data collected to create a coherent narrative, as well as explaining how individual censorship decisions were rationalised and discussed, requires what Michael R. Hill calls "an iterative process", involving the way in which "researchers organize and impute meaning to the archival strip through repeated reconsideration of older data combined with the constant infusion of new data. ${ }^{23}$ As he argues, this places the researcher in a rather different position from those involved with the historical events documented in the archival sources, giving them "the potential to read and reread archival data with the benefit of hindsight and widening understanding", finding meanings not necessarily obvious to the historical actors themselves. ${ }^{24}$ Thus, documents are not simply taken at their initial face value on first reading, but can gain new importance and significance in light of other documents uncovered subsequently. In the case of this thesis, awareness of wider institutional pressures and norms developed over time as more documents were analysed. This helped to create an understanding of previously examined documents and how they relate to each other, even if significantly separated by time and institutional actors involved. For example, patterns and similarities in discourse around censorship can be seen in correspondence by different Ministers of Internal Affairs at different times, which is something that is not immediately evident when examining archival sources.

While Gary McCulloch notes that "documentary research is often thought of as one single type of source", in many cases, including that of the material held in Archives New Zealand on film and video censorship, it "actually offers a number of different perspectives from which to view a given problem or topic". ${ }^{25}$ McCulloch offers a hypothetical example where "the combination of a published report and the archival records of the committee that produced it will give more insight into the nature of the report than either of them on their own", and the material I have examined for this thesis offers similar opportunities for triangulation and comparison. ${ }^{26}$ For example,

\footnotetext{
${ }^{23}$ Michael R. Hill, Archival Strategies and Techniques (Thousand Oaks: Sage, 1993).

24 Ibid.

${ }^{25}$ McCulloch, 129.

${ }^{26} \mathrm{McCulloch}, 129$.
} 
informal meeting notes and the Chief Censor's daybooks, as material not made public in any way at the time they were created, tended to be more candid than more widely distributed material such as official correspondence and formal reports of censorship decisions. Thus, they reveal aspects of the way censors went about their decisionmaking process that they were not always willing to make overt, and highlight the difference between public and private discourse. Such differences also suggest that there is a distinction to be made between the public rationalisation of censorship decisions, often made after the decision has been made and then challenged by groups such as the SPCS, and the more untidy reality of how the decisions were actually made. Similar types of sources also reveal different insights depending on the individuals involved. For example, Arthur Everard tended to provide extremely detailed explanations of his censorship decisions in response to correspondence from members of the public and representatives of groups such as the SPCS, and was much more blunt and candid than his predecessor Bernard Tunnicliffe or his successor Jane Wrightson. However, while there is a wealth of archival material covering New Zealand film and video censorship, no archive is ever a complete record, and as Deacon et al argue, "you must take into account these gaps and limitations, and make them clear when you present your results." ${ }^{27}$ For example, in the archival material on censorship, the "official" views of key institutional actors are widely recorded, but their more candid and personal views are only sometimes articulated, and thus it can be hard to determine how far the latter have guided the decision-making process. Deacon et al also argue that:

We expect someone who has invested considerable time in getting to know a culture to produce better-informed accounts than a casual visitor. So you need to take into account differences in sources' relevant experience and expertise when assessing what weight to place on their evidence. ${ }^{28}$

However, "better informed" does not necessarily mean telling the full story, and this can be related to understanding the purpose of documents when analysing them. As Richard Evans argues:

A text is always written for a readership and framed according to the writer's expectations of how the intended readers will take it. Similarly, the reader is always mindful of the purposes and

\footnotetext{
27 Deacon et al, 298.

28 Deacon et al, 301.
} 
intentions of the writer during the act of reading. All this remains true even when people read a document not addressed to them - people like historians, in fact. ${ }^{29}$

In the case of archival material on New Zealand film and video censorship, the "intended reader" may be a member of public, another key institutional actor, or even the writer his or herself (in the case of daybooks and informal file notes). The original purpose of any particular document is something which must be taken into account when assessing its significance and potential meaning.

As well as triangulation of different types of archival material in order to provide a fuller account, interview data has also been used to provide a different perspective. As Lucas and Strain argue, "[t]he interview can, in fact, be the arbiter of reliability", through revealing "inconsistencies, gaps and silences". ${ }^{30}$ This approach is typical of much social science research - as McCulloch notes, "[p]robably the most common approach" to combining documentary and non-documentary source material is "to relate archival records to interviews of living respondents". ${ }^{31}$ Taylor et al suggest that interviews can be used to "elicit a more or less honest rendering of how informants actually view themselves and their experiences" ${ }^{2}$, and similarly Nelms argues that interviews "can provide knowledge about individuals' motivations, attitudes, and feelings", thus providing a useful counterpoint to documentary evidence. ${ }^{33}$ Triangulation and comparison between the views expressed in documentary material, and the more reflective views in interviews, allows for a more nuanced account of censorship practice and how it was rationalised.

While not the main focus of this thesis, some limited textual analysis has allowed for the assessment of how far the claims made by various people and organisations about certain films are reflected in the actual content of the films. A model for the approach I have used is Martin Barker's analysis of Child's Play 3 (1991) in relation to the negative press coverage it received in the UK when it was erroneously linked to the murder of James Bulger. Acknowledging that Child's Play 3 is "not a very good film", Barker stresses that this is not the key point, but that what is important in this case is

\footnotetext{
${ }^{29}$ Richard J. Evans, In Defence of History (London, Granta Books, 2000), 104-105.

30 Lucas and Strain, 261.

${ }^{31}$ McCulloch, 129.

32 Taylor et al, 126.

${ }^{33}$ Gerald Nelms, "The Case for Oral Evidence in Composition Historiography," Written

Communication 9, no. 2 (1992): 380.
} 
"what kind of film it is, and what could reasonably be claimed about it". ${ }^{34}$ Barker suggests that the mental image created by the discourse surrounding the film is very different to the actual content of the film, arguing that it is

the exact opposite of everything that was said about it; this is in fact one of a thousand films which show a sort of rite of passage of adolescence: a misunderstood, essentially gentle boy gains courage and a girlfriend through the need to confront evil. Misunderstood and maltreated by the adults around him, he does the right thing, no matter what the cost to himself. This is a very moral tale..$^{35}$

Thus, the emphasis of any textual analysis is not on how "good" the films are, but what their meanings are and what sort of messages they convey, and how far the "imagined" film suggested by some of the discourse around it differs from the actual film itself. However, as Janet Wasko notes in her discussion of the political economy of communications:

Historical work in the film industry has also been the focus of political economists, who have countered the typical emphasis by film scholars on texts and genres by focusing on the commercial and industrial aspects of film. ${ }^{36}$

These "commercial and industrial aspects of film" include the censorship process, as getting a film classified by the censor was, and remains, an essential part of cinema film distribution in New Zealand. Thus, textual analysis undertaken in this thesis is to complement, clarify and expand upon the discussion of the censorship of the films in their historical context, rather than as the "typical emphasis" of much film scholarship which Wasko identifies.

\section{Typology of censorship decision-making rationalisation}

As part of the methodological approach of examining archival material through an "iterative process" through which analysis of documents feeds back onto itself, I have

\footnotetext{
${ }^{34}$ Martin Barker, "The Newson Report: A case study in 'common sense'." In III Effects: The Media/Violence Debate, 2nd ed., edited by Martin Barker and Julian Petley (London: Routledge, 2001), 32.

35 lbid., 33.

36 Janet Wasko, "The Political Economy of Communications." In Mass Communication Research Methods: Volume 2, edited by Anders Hansen (Los Angeles: Sage, 2008), 9.
} 
developed a typology of modes of censorship rationalisation. This constitutes both a significant part of my findings, but also a major part of my methodology, and thus requires some discussion here. While analysing the data and putting together an historical narrative, I observed that the way in which many of the censorship decisions were rationalised and explained had little to do with the manifest content of the films themselves. Instead it occurred in a discursive space outside of this manifest content. In textual analysis, "manifest content" is defined as "the explicit meaning of the text: that which is denoted or directly depicted". ${ }^{37}$ However, as part of the overall process of censorship in the case studies which I have examined, manifest content is actually a relatively minor element. Most of the decision-making and rationalisation of film censorship occurs outside the realm of manifest content, and into various areas of competition for discursive legitimacy. While Watson and Shuker note that the concept of "injuriousness to the public good" was "thought to give a measure of direction" to censorship decisions in contrast with the "discretionary clause" under which the Chief Censor had previously operated ${ }^{38}$, the case studies examined in this thesis suggest that it did not necessarily result in more "objective" censorship decisions than before the passage of the Cinematograph Films Act 1976. Discussing the similar concept of perceived "harm" in relation to British video censorship, Julian Petley argues that the concept "remain[s] stubbornly opaque", but that

[i]n recent years, the terms 'harm and offence' have replaced 'taste and decency' in legislation governing media content, and politicians and regulators have tended to suggest that the former pairing denote more 'objective qualities of media content than the latter. ${ }^{39}$

Petley argues that in the British context, "harm' is interpreted in such a broad way as to inevitably involve the censors in what are essentially moral judgements", although "[f]or obvious reasons, this is rarely admitted". ${ }^{40}$ This tension is also evident in New Zealand film and video censorship.

The modes of rationalisation involved in the censorship process which I have identified are as follows. They illustrate that censorship is very much about competing

\footnotetext{
37 Daniel Chandler and Rod Munday. A Dictionary of Media and Communication. Oxford: Oxford University Press, 2016.

38 Watson and Shuker, 51.

39 Julian Petley, Film and Video Censorship in Contemporary Britain (Edinburgh: Edinburgh University Press, 2011), 96.

40 lbid., 96.
} 
discourses, and which of these discourses are given the greatest weight and importance, as well as the subjective nature of the concept of "injury to the public good".

- Opinions regarding the nature of the perceived impact of specific films, or cinema in general, on audiences

- The viewing context of a film, including whether a film is viewed in a cinema or on home video, and the restriction of films to certain types of screenings such as for film festivals or film societies

- The views of lobby groups such as the Society for the Promotion for Community Standards, and the perceived reaction they might have to censorship decisions

- Judgements about the quality and cultural importance of particular films

- Judgements about the tone of particular films and how they present certain content, rather than simply the content itself

- Appeals to normative standards, such as whether a film would be acceptable to what were perceived to be "community standards"

- Appeals to third party authorities, such as representatives of certain institutions like the police, members of the general public who were consulted regarding certain films, and academic research regarding films and their impact on audiences

- The wider social context surrounding the release or potential release of a film

- The perceived realism of any particular film, including how accurately it is seen as portraying certain aspects of society

- The distinction between what is considered "injurious to the public good" and what is considered potentially "offensive" to much of the public, but not "injurious"

- The use of language that is contentious and unclearly defined, such as "gratuitous", in the justification of censorship decisions

This typology provided the basis for the analytical sections after each case study in this thesis, identifying which were given the greatest weight in the rationalisation and justification of any given censorship decision. Through identification of these modes of rationalisation, I was able to more clearly identify patterns and trends in the way censorship operated, and these were then applied back to earlier analysis in order to 
clearly trace the historical development of censorship during the period from 1976 to 1994. A timeline indicating the modes of rationalisation for the film case studies is included in the Conclusion.

\section{Chapter summary}

This chapter has outlined the data collected and methodological approach for this thesis. This methodology has evolved and developed throughout the research process, resulting in the development of a typology of rationalisations of censorship decisions which has informed the analysis of the censorship case studies in following chapters. These chapters provide a chronological overview of film and video censorship in New Zealand with a focus on the tenures of three Chief Censors, Bernard Tunnicliffe, Arthur Everard and Jane Wrightson. 


\section{Chapter Three: Chief Censor Bernard Tunnicliffe, 1976-1983}

\section{Chapter overview}

1976 saw the passage of new film censorship legislation in the form of the Cinematograph Films Act 1976, which fundamentally changed New Zealand film censorship by introducing the concept of "injurious to the public good" as a means by which to determine whether a film required restriction, cuts, or a ban. The first Chief Censor to operate under this new legislative regime was Douglas McIntosh's successor, and former Deputy Chief Censor, Bernard Tunnicliffe, who had two Deputy Chief Censors. Censorship was the political responsibility of the Minister of Internal Affairs, who did not have the power to directly intervene in the censors' decisions, but could have a film withdrawn and referred to the Films Censorship Board of review if it was determined that "the further exhibition of the film is likely to be injurious to the public good". ${ }^{1}$ This chapter focuses on the period from 1976 to 1984 , with some discussion of film censorship prior to this period in the case of Last Tango in Paris. The case studies examined are Bernardo Bertolucci's Last Tango in Paris and George Miller's Mad Max, both initially banned in New Zealand, the New Zealand-made films Angel Mine and Goodbye Pork Pie, and the Monty Python film Life of Brian, all of which were subject to some controversy but were passed by the censor uncut with age restrictions. Rather than simply looking at censorship as the application of prescriptive legislative rules, this chapter examines the way in which these contentious films became sites of contested discursive legitimacy, and how the understanding of censorship cannot be limited to a single decision, but should be conceived of as a process that can both precede and follow that decision.

\footnotetext{
${ }^{1}$ Cinematograph Films Act 1976, Section 85(1).
} 


\section{Last Tango in Paris - historical narrative}

The censorship history of Last Tango in Paris provides a case study illustrating both a unique set of circumstances, and a number of issues and themes which would persist throughout the period which I have examined. It is unique in that it was a significantly controversial film that was banned in New Zealand under one piece of legislation, and only a few years later passed uncut by a new Chief Censor under new legislation which had been intended to liberalise film censorship. While it is difficult to clearly determine which of these changes had the most impact on the decision to approve the film for public exhibition, a detailed examination of the censorship history of Last Tango in Paris in New Zealand provides a nuanced view of the situation, complicating any attempt at a simple narrative which focuses on only one of the changes as the key factor.

The way in which the film was treated by New Zealand censors also illustrates themes that reoccur through the period from the 1976 Cinematograph Films Act to the 1993 Films, Videos and Publications Act, such as the tension between the claims of objectivity of the censors, and the way in which the process of censorship actually worked; the significance of the issue of artistic merit in the censorship process; the relatively consistent views on the subject of media effects expressed by different censors and Ministers of Internal Affairs; and the way in which censors and politicians gave legitimacy to certain public discourses around censorship while others were marginalised and not considered to be an important element in the process of film censorship. As with many censorship decisions, those made on Last Tango in Paris were explained and justified through the deployment of discourse that was contentious and not always clearly defined, casting doubt on any claims of "objectivity" on the part of the various censorship authorities. The way in which the decision to eventually pass the film was discursively framed set a pattern for such rationalisation by both the Chief Censor's Office and the Minister of Internal Affairs that would continue throughout the period which I have examined, demonstrating a degree of institutional continuity across multiple Chief Censors and ministers.

Last Tango in Paris first arrived in 1973 New Zealand on the back of a large amount of controversy and censorship problems overseas, so the film's reputation preceded 
it. While David Thompson notes that the film "has now quietly passed into the category of films whose controversies no longer seem important", at the time of its original release it was one of the most talked-about films in the world. ${ }^{2}$ In Bertolucci's native Italy, it was briefly pulled from distribution as the result of a private prosecution for obscenity. This ban lasted less than a month, but an appeal by the prosecution was eventually successful and in 1976 "the High Court of Cassation condemned the film, finding it 'obscene' and ordering the confiscation of all extant prints". ${ }^{3}$ The film was not cleared of obscenity in Italy until 1987. ${ }^{4}$ In the United Kingdom, the film was the subject of sensationalist tabloid press coverage, although the British Board of Film Censors noted in their report that "the film is certainly not as pornographic as the newspapers would have us believe", and that "language rather than visuals...seem to be the only real problem". ${ }^{5}$ However, it was in fact "visuals" that were the eventual target of the BBFC's scissors, in the case of the "notorious sodomy scene". In this scene, Marlon Brando's character Paul has anal sex with Maria Schneider's character Jeanne with the assistance of butter as a lubricant, and it was cut by ten seconds to remove "the specific shot of Paul inserting his fingers between Jeanne's buttocks" to apply the butter. ${ }^{6}$ While this cut "did not satisfy the moralistic hunger" of British campaigners for stricter censorship, in the case of Last Tango in Paris, the film's artistic reputation provided a way for the British censors to defend their decision, as they "enjoyed the crucial advantage of facing their moral opponents with the critics on their side". ${ }^{7}$ Indeed, preeminent American film critic Pauline Kael was one of the film's most vocal defenders, arguing that it was an important milestone in film history. Looking back on Kael's review, Linda Williams later argued that Kael saw that the film's "particular sense of taking on sexual themes in the non-romanticized, primitive ways of modern art" suggested that "movies had finally grown up". ${ }^{8}$ Thus, the film negotiated competing claims about its obscenity and artistic merit prior to and during its encounters with New Zealand's film censors.

\footnotetext{
2 David Thompson, Last Tango in Paris (London: BFI, 1998), 24.

3 Ibid., 21.

${ }^{4}$ Aldo Miceli, "Last Tango in Paris: Death, eroticism, and the female Oedipus," The Italianist 21, no. 1 (2001): 153.

5 Thompson, 23.

6 Ibid., 23.

7 Tom Dewe Mathews, Censored (London: Chatto \& Windus, 1994), 212.

8 Linda Williams, Screening Sex (Durham: Duke University Press, 2008), 113.
} 
While Last Tango in Paris was one of the first significantly controversial films to come before the Chief Censor after the 1976 Cinematograph Films Act introduced the concept of "injurious to the public good", to fully contextualise the decision to pass it at that time, it is necessary to look at the film's censorship history in New Zealand prior to this. When Last Tango first arrived in New Zealand in 1973, the Chief Censor was Douglas McIntosh, working under the 1961 Cinematograph Films Act. Mclntosh banned the film on 18 April 1973, on the basis "[t]hat the film is contrary to public decency and its exhibition would be undesirable in the public interest". This was the standard justification given for banning films under the 1961 Cinematograph Films Act; the legislation not requiring the Chief Censor to give any more reason than this for his decision, nor providing any definition of such terms as "public decency" or "public interest". This ban was appealed by the distributors, United Artists, and the film went before the Cinematograph Films Censorship Board of Appeal, which at the time consisted of three members, as set out in the 1961 Act. This Act also made provision for "[e]very party to an appeal against a decision of the Censor" to be represented by legal counsel. ${ }^{9}$ At the beginning of the Board of Appeal hearing on Last Tango, Solicitor-General R.E. Savage noted that while in past Board hearings "counsel have appeared and made submissions, offered argument for the censor", the law did not necessarily require this, but L.W Brown, the counsel for the film's distributors United Artists, considered that it would be useful "to have the two sides advanced". 10 Therefore, the hearing went ahead in a manner Brown later described as "a full-scale adversary hearing", ${ }^{11}$ with five witnesses called by Brown including a newspaper editor, a Presbyterian minister and a professional writer, a group considered to be "sufficiently representative to be helpful to the board" in determining public standards. ${ }^{12}$ The legalistic nature of the hearing meant after both the New Zealand Federation of Film Societies and the SPCS wrote to the Board of Review about the appeal, they were warned by the Solicitor-General that contempt of court proceedings had been considered but ultimately rejected, and that it was "plainly undesirable that

\footnotetext{
${ }^{9}$ Cinematograph Films Act 1961, Section 97(5).

${ }^{10}$ ACGO 8333 IA1W1893 3 Part 1 - Cinematograph Films - Appeal against Censor's decision 'Last Tango in Paris' 1st hearing.

${ }^{11}$ ACGO 8333 IA1W1893 3 Part 2 - Cinematograph Films - Appeal against Censor's decision 'Last Tango in Paris' 1st hearing.

12 ACGO 8333 IA1W1893 3 Part 1 - Cinematograph Films - Appeal against Censor's decision 'Last Tango in Paris' 1st hearing
} 
people should endeavour to influence the outcome of an appeal by communication with members of the Board". ${ }^{13}$ This desire to avoid undue outside influence resulted from the adversarial and legalistic nature of Board of Appeal hearings under the 1961 legislation. Such concerns were not raised by the reconstituted Board of Review under the 1976 legislation, which removed the allowance for legal counsel, and gave the Board the "same power to consult any person" that the Chief Censor had also been given. ${ }^{14}$

The Chairman of the Board of Appeal, W.H. Carson, opposed the film being passed for exhibition, and contrasted this with the Board's decision the previous year to overturn the Chief Censor's ban on Ken Russell's film The Devils (1971). In that case, Carson argued that despite "the explicit and graphic manner in which events were depicted" in The Devils, which some people may find "visually shocking and/or disturbing", he considered that it "nevertheless did not depict matter which was contrary to public order or decency; nor would its exhibition for any other reason be undesirable in the public interest". However, he does not fully explain his reasoning for not giving Last Tango in Paris the same consideration, or attempt to define the way in which he used terms such as "undesirable in the public interest", merely stating that "the conclusion I have reached concerning the "Tango" film is directly opposed to that arrived at by the Board in respect of "The Devils". ${ }^{15}$ Board member M.J. Clark also opposed the film being passed, issuing a brief statement that she "concur[red] with and have nothing further to add to the Chairman's analysis of the situation". ${ }^{16}$

However, the dissenting opinion of the third member of the Board, W.N. Sheat, is significant as it demonstrates the way in which censorship law could be interpreted very differently when it came to assessing a contentious film - the members of the Board could not agree on a single legally "correct" decision. Sheat supported passing the film with an R20 certificate, albeit with the proviso that "the so-called "sodomy scene" [which] did go further than current standards would tolerate" needed to be "reduced or cut entirely", although it is not clear precisely how he determined these

\footnotetext{
${ }^{13}$ ACGO 8333 IA1W2633 5 - Cinematographic Films - Film - The Last Tango in Paris 1973.

${ }^{14}$ Cinematograph Films Act 1976, Section 84(4).

${ }^{15}$ ACGO 8333 IA1W1893 3 Part 1 - Cinematograph Films - Appeal against Censor's decision 'Last Tango in Paris' 1st hearing.

$16 \mathrm{lbid}$.
} 
"current standards". ${ }^{17}$ Notably, Sheat appeared to be criticising the very legislative basis under which film censorship decisions were made at that time, expressing his disappointment that the perpetuation of the "discretionary clause" throughout all film censorship Acts since 1916 meant that "it is necessary to approach the serious consideration of "Last Tango in Paris" armed with a formula which was originally designed to enable the community of 1916 to protect itself from the excesses of silent films". ${ }^{18}$ Sheat certainly regarded Last Tango in Paris as a film worthy of such "serious consideration", explaining that he considered it "a film of serious intent [which] should not be classed as having been made merely to exploit certain aspects of its subject matter"19. This assessment echoed Pauline Kael's review of the film, which argued that it "downplays prurience, attaching that feature to other kinds of films", this "other kind" being low-budget exploitation films which lacked Last Tango's artistic merit. ${ }^{20}$ Sheat suggested that he considered it necessary to look at a film as a whole when making censorship decisions, making the statement that "[t]o isolate particular scenes and language and then list them consecutively as Mr [R.E.] Savage did, does tend to shock but these elements must be looked at in the context of the film as a whole". ${ }^{21}$ However, in this case, Sheat appears to be anticipating future censorship law rather than working strictly under the provisions of the existing legislation at the time. While the 1976 Cinematograph Films Act would require that the "dominant effect of the film as a whole" be taken into account, the 1961 Act under which the Board was operating referred to "any film or to any part of a film which in his opinion depicts any matter that is contrary to public order or decency, or the exhibition of which would for any other reason be undesirable in the public interest". ${ }^{22}$ This suggests that parts of a film could be considered in isolation, and thus be subject to censorship even if they were arguably justified by context.

Since Sheat's was the minority opinion, the ban on Last Tango in Paris was upheld by the Board of Appeal on 27 September 1973 in a majority decision. Less than a year later, the film came before the Chief Censor again. In advance of the Censor's

\footnotetext{
17 Ibid.

18 Ibid.

19 Ibid.

20 Williams, 2008, 119.

${ }^{21}$ ACGO 8333 IA1W1893 3 Part 1 - Cinematograph Films - Appeal against Censor's decision 'Last Tango in Paris' 1st hearing.

${ }^{22}$ Cinematograph Films Act 1961, Section 14(1). Emphasis added.
} 
decision, a representative from the film's distributor United Artists wrote directly to Douglas Mclntosh suggesting that the film could now be passed:

Because of the history of this film and having regard for what, with respect, we now consider to be the contemporary standards which exist in this country we are taking the liberty of suggesting what the Company feels would be appropriate and acceptable restrictions to be endorsed on your certificate. ${ }^{23}$

These suggestions mirrored W.N. Sheat's minority opinion from the previous Board of Appeal decision, arguing that the film should receive an R20 certificate with a warning about content that may offend, and that "the so-called "Sodomy scene" be reduced", although the distributors did not take the opportunity to submit an already pre-cut version of the film. ${ }^{24}$ However, McIntosh was not persuaded, and the film was again banned on 8 February 1974.

The decision was appealed a second time, although the Board of Appeal did not make their decision until 27 June 1975. Also for a second time, the ban was upheld by a majority decision of two to one, although the differing rationales offered by both sides from those expressed in the previous Board of Appeal decision again highlight the degree of subjectivity in such decision-making, and the contentious and ill-defined nature of much of the language used. Board Chairman A.J. Lloyd Martin believed that the ban should stay, arguing that the film "offends against the current standards of the community and therefore its exhibition would be undesirable in the public interest", although he did acknowledge that in the actual wording of the 1961 legislation, "there is no definition as to what is "public order or decency" or "undesirable in the public interest". ${ }^{25}$ While Sheat had previously argued that the film could be cut, Lloyd Martin considered this not to be a realistic option, as "certain scenes could not be omitted without destroying the whole fabric". ${ }^{26} \mathrm{He}$ also dismissed the issue of the film's perceived artistic quality as not being relevant, arguing that reviews of the film could not be considered in his decision and that he "must take into account those specific considerations" in the current film censorship legislation, artistic merit not being

\footnotetext{
${ }^{23}$ AAAC W4303 Box 1 - [Cinematograph Films Board of Appeal] 1956-1976.

24 Ibid.

${ }^{25}$ ACGO 8333 IA1W1893 3 Part 2 - Cinematograph Films - Appeal against Censor's decision 'Last Tango in Paris' 1st hearing.

26 lbid.
} 
mentioned in the 1961 Act. ${ }^{27}$ Board Member M.R. Nolan also opposed passing the film for exhibition, arguing that "it is technically a brilliant piece of work" but not "sufficiently important to warrant releasing it uncut". ${ }^{28}$ This appears to contrast with Lloyd Martin's interpretation of the legislation, as Nolan implies that a perceived greater "importance" may have allowed her to consider passing the film, whereas Lloyd Martin believed that artistic merit was not able to be considered in such a manner.

As well as issues of artistic merit, viewing context was a factor in the Board's decision. Nolan argued that a cinema in "a metropolitan area where there were not only cinemas but also a variety of other entertainments and diversions" could be regarded as not constituting a public place, but in a small town "where there might well be no alternative forms of entertainment", a cinema was a public place. ${ }^{29}$ Thus, her decision to ban the film stemmed from her belief that "this decision must be made within the environmental context of the smaller towns and communities of New Zealand". ${ }^{30}$ She also suggested that the film would have a negative impact on audiences, as it offered "little of value for the majority of people who would see it", that the "average film goer" would not understand the film's subtleties and thus it "could be construed as largely meaningless and obscene", and that "for many people...it would increase a sense of meaninglessness and hopelessness". ${ }^{31}$ Such an influence she considered "cannot be seen to be commensurate with the public good". ${ }^{32}$ She did suggest that the film could potentially be screened by film societies, but considered that "Film Society members are not an elite of any sort within the community and the Board would have to take care that it did not give the impression that this was so". 33

The only dissenter, board member R.A. Sharpe, gave a different argument regarding viewing context, suggesting that the legislation was open to wide interpretation when making censorship decisions. In supporting passing the film uncut with an R20 certificate. Sharpe argued that "place and circumstance" was important, and that there

\footnotetext{
27 Ibid.

$28 \mathrm{lbid}$.

$29 \mathrm{lbid}$.

30 lbid.

$31 \mathrm{lbid}$

32 lbid.

33 Ibid.
} 
was a significant difference between "decency" if "these words and actions...happened in a public street" versus "in a cinema, watching a film with an R20 certificate". ${ }^{4}$ Unlike Nolan, Sharpe made no distinction between cinemas in different locations. Sharpe's interpretation of the existing censorship legislation appeared to anticipate the more liberal 1976 Cinematograph Films Act, and the concept of "injurious to the public good", as he suggested that films should only be banned if they were somehow "a threat to our safety and way of life", and that "[o]nly very weighty considerations of public 'hygiene' could outweigh the right to see the movie". ${ }^{35} \mathrm{He}$ did also argue that passing the film for public exhibition could be seen as an "experiment in the public interest" as releasing it would "enable the Board more clearly to gauge the state of public opinion". ${ }^{36}$ However, Sharpe was outvoted and the film remained banned.

The new Cinematograph Films Act 1976 came into force on 1 April 1977, and Bernard Tunnicliffe had taken over as Chief Censor after the death of Chief Censor Douglas Mclntosh in 1976. Tunnicliffe had worked as a film censor since 1959, first as an assistant censor, and then as Deputy Chief Censor under Mclntosh from 1967. He was not initially appointed as Chief Censor, but appealed to the Public Service Appeal Board successfully after the post was given to Northcote teacher Philip McHale. ${ }^{37} \mathrm{He}$ was "by his own admission a conservative" ${ }^{38}$, and described himself in a Listener profile on his appointment as "just a servant of the public trying to interpret their views and their wishes". ${ }^{39}$ Under Tunnicliffe and the new legislation, Last Tango in Paris came before the censors yet again, but this time was passed uncut on 18 August 1977 with an R20 certificate. While the issue of artistic merit was again a consideration, a notable aspect of this decision and the way it was justified was what Des Freedman describes as "ideological legitimation", when "certain ideas are normalized and others problematized". 40 The Chief Censor and Minister of Internal Affairs Allan Highet both gave greater value to certain views on the film over others, regarding opinions based on lack of direct personal knowledge of the film as having less validity.

\footnotetext{
34 Ibid.

35 Ibid.

$36 \mathrm{lbid}$

${ }^{37}$ Evening Post, 28 December 1995.

38 Ibid.

39 NZ Listener, 8 October 1977, 17.

${ }^{40}$ Des Freedman, The Politics of Media Policy (Cambridge: Polity Press, 2008), 3.
} 
The decision to pass Last Tango in Paris was met with letters of protest to both Tunnicliffe and Highet, and as had previously been the case with a number of controversial films, and would continue to be the case through the 1970s and 1980s, much of this opposition to the film stemmed from the SPCS. The Society's September 1977 newsletter argued that "as predicted by the S.P.C.S." the 1976 Cinematograph Films Act had "opened the floodgates to obscenity in scenes and dialogue", evidenced by the fact that Last Tango had been passed uncut. The newsletter encouraged members to write to the Prime Minister, Leader of the Opposition, Minister of Internal Affairs, and Chief Censor, on the grounds that "citizens who make the biggest noise get the biggest hearing with government". ${ }^{41}$ However, the responses of the Chief Censor Bernard Tunnicliffe and Minister of Internal Affairs Allan Highet to the letters of complaint they received suggest that they were not in any way swayed by the "noise" created by the Society for the Promotion of Community Standards.

Tunnicliffe's responses provide an insight into his philosophy of censorship and how he interpreted the new film censorship legislation, although his explanations demonstrate a tension between his stated objectivity and his own subjective interpretation of matters such as community standards, as his "objective" decisions were based upon his determination of what such community standards actually were. Even if one assumes that there are objective "community standards" out there to be discovered, the process of attempting to determine what these are adds several layers of subjectivity between those standards and the final censorship decision. In most of his letters to those protesting the decision to pass the film, Tunnicliffe stressed that he had to take into account the views of the wider public, as well as make his decisions in an objective manner based on the law. For example, in one letter dated 7 October 1977, he explained:

My decisions are based on the specific guidelines and criteria set out in the Cinematograph Films Act, and in interpreting these I am required to take into account, opinions, attitudes etc expressed by the public as a whole. The decisions which follow may not be acceptable always to one's beliefs and attitudes, but they are objective decisions based on the law not subjective ones based on emotive values. ${ }^{42}$

\footnotetext{
${ }^{41}$ Newsletter No. 23, Society for the Promotion of Community Standards, September 1977.

${ }^{42}$ AAAC W4442 Box 8 - Controversial/Interesting \& Some Rejected Films - Last Tango in Paris 19771979.
} 
In other correspondence, Tunnicliffe further explained this position, arguing that he believed that the views of the "public as a whole" had changed significantly in recent years:

Standards and attitudes have changed rapidly over the last decade or so, and it is this change which is being reflected in and being accepted in the films being made today. ${ }^{43}$

He also explained to one correspondent how his office went about determining what such standards were:

With that in mind I, like my predecessor, have spoken over the years (and still do) to many and varied groups in different parts of the country and if this does not make me reasonably familiar with the values of our fellow countrymen [sic] then I know of no other more satisfactory way of obtaining this information. ${ }^{44}$

Further reiterating his stated commitment to objectivity, in response to one correspondent's assertion Tunnicliffe denied that Last Tango was "something of a test case" for the new legislation, and that it was simply "another film... on which a decision had to be made in terms of the law", and that it had not set a precedent as any future films would have to be "dealt with on their respective merits". ${ }^{45}$ Tunnicliffe also argued that the effect of Last Tango in Paris on viewers was not as great as had been suggested by some of the film's opponents, noting that "[t]here has been a great deal reported about the "impact" of this film", but that there was no real evidence linking it to "a decline in moral principles and attitudes". ${ }^{46}$ This assumedly referred to the film's reception overseas, as it had not yet screened publically in New Zealand. However, Tunnicliffe did state that "[m]any New Zealanders have seen this film since it was first released overseas, and of those I have known and have spoken to there is no evidence of change in their standards of moral values". ${ }^{47}$ Beyond the alleged impact of Last Tango in Paris itself, Tunnicliffe also argued that it was debatable whether films in general could be seen to have the straightforward impact upon viewers which some of the letter writers attributed to them. In one letter, he wrote that there is "considerable division of opinion on the question of whether films by themselves do have any real affect [sic] on viewers", and other factors that may influence behaviour include "home,

\footnotetext{
43 Ibid.

44 lbid.

$45 \mathrm{lbid}$

46 lbid.

47 lbid.
} 
school and social backgrounds, stage of development, [and] degree of intelligence". ${ }^{48}$ While some press coverage oversimplified the Chief Censor's decision-making process, such as a report in The Dominion noting that the film was passed under the new legislation which "enables a film's overall artistic merit to be considered" 49 , Tunnicliffe himself argued that "it was only one of the factors that were relevant" in choosing to pass the film. ${ }^{50}$ As with many cases of film censorship, the decision involved balancing of a number of different considerations, and cannot be simply attributed to one factor.

Although many of the letters that Minister of Internal Affairs Allan Highet received called upon him to exercise the power he had to refer Last Tango in Paris to the Board of Review for re-examination, he did not do this, and was strongly supportive of the Chief Censor's decision to pass the film. Like Tunnicliffe, he stressed the need under the new legislation to take the views of the wider public into account. As he explained in a letter dated 12 October 1977:

Furthermore, it is not [the Chief Censor's] responsibility to impose either his standards or the standards of any other person or organisation in reaching a decision on any film. It is his onerous task to reflect, but not surpass, the standards which are acceptable to society generally. ${ }^{51}$

Highet also made it clear that he did not consider complaints made about Last Tango in Paris based on second-hand knowledge to be worthy of serious consideration. In one letter dated 10 October 1977, he suggested that the correspondent "may have been misinformed about the exact nature of the film", and in another on the same date, he noted that much of the correspondence he had received "appear[s] to have been based upon a misleading circular which suggested recipients write to me and their local member to express their objections to the film". ${ }^{52}$ This lack of legitimation of views seen as not being fully informed would continue throughout the period I have examined on the part of multiple censors and Ministers of Internal Affairs.

\footnotetext{
48 Ibid.

49 The Dominion, 23 August 1977.

${ }^{50}$ AAAC W4442 Box 8 - Controversial/Interesting \& Some Rejected Films - Last Tango in Paris 19771979.

${ }^{51}$ AAAC 7536 W5084 Box 27 - Chief Censor and Departmental Responsibility - Last Tango in Paris 1977.

52 Ibid. The "misleading circular" referred to was presumably the Society for the Promotion of Community Standards newsletter.
} 


\section{Other early censorship under the Cinematograph Films Act 1976}

Before analysing in depth the various means of rationalising the censorship decisions around Last Tango in Paris, it is worth looking at some contrasting decisions taken by the Chief Censor around the same time to provide some wider context. In the case of Last Tango, Tunnicliffe stressed that his censorship decisions were based on objective grounds, but material from the Chief Censor's daybooks during this period illustrates a tension between this publicly stated "objectivity" and apparently subjective "moral" objections to other films seen as having less artistic significance. Despite Tunnicliffe's decision to pass Last Tango in Paris, it did not appear that this "opened the floodgates" to more permissive censorship to the extent which the SPCS had feared, and his office continued to ban a significant number of films - from 1 April 1977, when the new legislation came into force, until the end of 1979, the Chief Censor's office banned 38 feature films. ${ }^{53}$ For example, in 1977 the animated film Fritz the Cat (1972), based on Robert Crumb's cartoon strip, was banned with the following noted by Deputy Chief Censor Diane Wren in the daybook:

Film endorses free way of life as Fritz sees it: mostly in group love-ins. Law and order does not play any real part. A spurious work presenting a particularly vicious unbalanced view of society. ${ }^{54}$

The daybook notes also describe the film as "a vicious piece of work and somewhat prurient", albeit suggesting that it may be possible to pass the film for film societies it was not considered suitable for "general audiences" but may be able to be permitted for a "selective audience". 55 This idea that "general audiences" should not be exposed to certain films that may be considered suitable for a more limited audience was also demonstrated in the daybook notes on Australian director Phillip Noyce's film Backroads (1977). It was given an R18 rating and limited to the Wellington and Auckland film festivals only, with the following comment by Wren:

\footnotetext{
53 This total does not include trailers or multiple rejections by the censor of the same film.

${ }^{54}$ ADNB 23133 W5730 Box 168 - Daybooks of Chief Censor of Films - 19/4/77 to 23/8/77.

55 lbid.
} 
Strictly only approval for these 2 festivals. We share opinion that this is a realistic appraisal of Aust.[ralian] outback attitude. Nevertheless the film is relentless in its racist approach. Pass it only on the presumption that $F$. [estival] audience is a little more discerning. ${ }^{56}$

Ted Post's 1973 film The Baby received an even more scathing appraisal from Wren in the daybook than Fritz the Cat, and was also banned in 1977. The daybook notes state:

An insidious piece of "gloss" showing 2 psychopathic females in American society who each for slightly different but equally perverse ends, deliberately retard the development of a human being for their own ends....Abnormal, unnatural amoral women in "society" but shown to be outside the laws of that society. Total vice and corruption on a human level. ${ }^{57}$

This treatment by the Chief Censor's Office contrasts markedly with that displayed towards Last Tango in Paris when it was examined in 1977 by both Bernard Tunnicliffe and Diane Wren, with notes taken by the latter, since there is no clear evidence of a subjective "moral" judgement in the decision to pass the film with an R20 classification. ${ }^{58}$

\section{Last Tango in Paris - analysis}

As with many of the films I will be discussing in this thesis, the discourse surrounding the censorship of Last Tango in Paris placed little emphasis on the manifest content of the film, other than some mention of what David Thompson called the "notorious sodomy scene"59, with both Board of Review member W.N. Sheat and the film's distributors themselves singling the scene out as a point of contention. Sheat argued that, even taking his favoured approach of considering the film as a whole rather than focusing on "particular scenes and language", the "sodomy scene" could not be justified by context. Other than this, the discussion around the film was notable in its lack of specificity in terms of the film's actual content. In contrast with the views of Sheat and the film's distributors that Last Tango in Paris could potentially be subject

\footnotetext{
${ }^{56}$ ADNB 23133 W5730 Box 171 - Daybooks of Chief Censor of Films - 5/9/77 to 3/7/78.

$57 \mathrm{lbid}$.

${ }^{58}$ ADNB 23133 W5730 Box 168 - Daybooks of Chief Censor of Films - 19/4/77 to 23/8/77.

59 Thompson, 1998, 23.
} 
to excisions in order to allow it to screen, other Board of Review members interpreted the film in a rather different way, seeing problems with the overall tone of the film rather than any specific aspects of manifest content. As Italian film scholar Aldo Miceli argues, the film was not especially visually explicit in its portrayal of sex, and

it is clear that the outcry of the censors and the negative public reaction had more to do with how the film portrays sexuality and with its function in the text. The very controversy Last Tango aroused substantiates the idea of eroticism as a powerful force within the individual and as a threat to the social system. 60

Such an interpretation perhaps explains the strong but imprecisely articulated views on the film, such as M.R. Nolan's claim that it "it would increase a sense of meaninglessness and hopelessness" among many of those who viewed it, suggesting that the negative reaction was to the film's overall bleakness rather than any particular individual scenes. Some scholars have similarly argued that it was not just the sexual content that made the film controversial: Yosefa Loshitzky suggests that it is "Bertolucci's most controversial and disturbing film primarily because of its treatment of sexuality, violence, and death". ${ }^{61}$

A variety of views were expressed on the perceived impact of the film on audiences by the members of the Films Censorship Board of Review in the two hearings on the film, and by Bernard Tunnicliffe, the Chief Censor who eventually passed the film for public exhibition. These views sometimes displayed a strong sense of the third person effect - "the perception that communications exert a stronger effect on others than on oneself" 62 - an attitude that censors perhaps by necessity have to adopt, but is not always expressed so explicitly. In particular, Board of Review member M.R. Nolan's positioning of herself as someone able to properly understand the film, while the "average film goer" would not, places a clear division between the censor and those whom censorship is supposedly intended to protect, and suggests a somewhat patronising view of the film's imagined audience. Strikingly similar views have been expressed by film censors in other countries, such as former British deputy censor

\footnotetext{
60 Miceli, 52.

61 Yosefa Loshitzky, The radical faces of Godard and Bertolucci (Detroit: Wayne State University Press, 1995), 179.

${ }^{62}$ Richard M. Perloff, "The Third Person Effect: A Critical Review and Synthesis," Media Psychology 1, no.4 (1999): 353.
} 
Ken Perry, quoted by Tom Dewe Mathews in relation to Abel Ferrara's film The Driller Killer63:

Now and again...you get clever dicks who say, "Aaah, this is art. This is bigger than it seems." But I think of Joe Bloggs who's going to the Odeon on Saturday night who's not on that wavelength. He's going along seeing it literally as it's presented and I always keep that in mind....Joe Bloggs is the majority and film censorship is for the majority. ${ }^{64}$

Bernard Tunnicliffe, working under the new censorship legislation, took a more nuanced view, and as well as commenting on Last Tango in Paris specifically, he also made some general comments on the perceived impact of the medium of cinema as a whole and the concept of media effects, arguing that film alone could not negatively influence and change beliefs and attitudes, but other contextual factors such as education and the home environment were important. While usually without reference to specific studies, this view was often supported with at least very general reference to research in this area, perhaps reflecting the shift in media effects theory in the $1950 \mathrm{~s}$ and 1960s away from a "transmissional' model" which "assumed direct effects" to the concept of "limited effects" which played down the importance of mass media in shaping individual beliefs, arguing that it was "more likely to reinforce existing attitudes than change them or create new attitudes". ${ }^{65}$ This perspective persisted across multiple Chief Censors and Ministers of Internal Affairs during the entire period from 1976 to 1994.

The views of lobby groups, in this case primarily the members of the Society for the Promotion of Community Standards, were not considered to be an important factor in the way in which the two Board of Review hearings and Chief Censor Bernard Tunnicliffe came to their decisions, although for different reasons. Board of Review members expressed their concern that directly contacting the Board in relation to a specific film could be seen as an undue influence, while Bernard Tunnicliffe, supported by Minister of Internal Affairs Alan Highet, argued that second-hand views on a film which were not based on personal knowledge of its content were not useful to him. In both cases, the SPCS's opinions were dismissed as not directly relevant to the process of censorship. Throughout the period which I have examined, views very

\footnotetext{
${ }^{63}$ The New Zealand censorship history of The Driller Killer is discussed in the following chapter. 64 Mathews, 251-252.

$65 \mathrm{Jim}$ R. Macnamara, Mass Media Effects: A Review of 50 Years of Media Effects Research (CARMAN International Research Paper) (2003), 2.
} 
similar to those of Tunnicliffe and Highet would persist with other censors and Ministers, with opinions considered to be sufficiently informed being given the greatest legitimacy, rather than the loudest and most prominent voices, such as the SPCS, being accorded significance as a result of their prominence. This has not always been the case with censorship discourse, as the contrast between the furore over "video nasties" in the UK and the more measured response in New Zealand, discussed in the following chapter, demonstrates.

Various opinions expressed by Board of Review members suggest that it was not merely the film itself, but the specific details of the potential viewing context, that were an important consideration. While many decisions to cut or ban films prior to the 1976 Act resulted from the interpretation of the cinema as a "public place", Board of Review member R.A. Sharpe felt that an R20 certificate would allow for a film to portray content that would not be acceptable if it "happened in a public street". M.R. Nolan's suggestion that Last Tango could have potentially been permitted to screen through film societies seems to be self-contradictory. She argued that members of film societies are not "an elite of any sort within the community", but if this was the case then surely such people would be included among the "average film goers" whom she considered would not fully understand the film and thus see it "as largely meaningless and obscene". Such concerns are perhaps reflective of some of the ways in which Simon Sigley argues that the development of an intellectual film culture was difficult in the New Zealand context, such as "a strong strain of egalitarianism which involved distrust of anything that resembled elitism". 66

While Last Tango in Paris was a polarising film that prompted a wide variety of responses from audiences, it was recognised as a film of significant artistic merit by many film critics upon its release, and continues to be seen as such today. As it was not a film that could be easily dismissed as lacking in quality, this became an issue in both the film's classification by both the Board of Review and Bernard Tunnicliffe. In the case of the Board of Review, there was some contradiction between the views of different members, with artistic merit regarded variously as something unable to be considered, a factor which could be considered but which did not outweigh other considerations against passing the film, and as a significant factor that would allow for

${ }^{66}$ Simon Sigley, Transnational Film Culture in New Zealand (Bristol: Intellect, 2013), 256. 
the film to be passed for public exhibition. Tunnicliffe argued that artistic merit was a factor that the law now allowed him to consider, but that it was only one factor among many. This contrasts with newspaper coverage which suggested that the inclusion of artistic merit in the new legislation was the main factor that allowed it to now be passed uncut, and thus illustrates the importance of a detailed archival approach in examining the censorship process, as it is sometimes misrepresented and oversimplified in public discourse of the time such as newspaper reports.

The 1977 daybook notes on Last Tango in Paris are purely descriptive and contain no evidence of negative moral judgements of the film, and this absence takes on some significance in light of the decisions made during this period on less "important" films. Such films often continued to be banned despite the new ostensibly more liberal censorship legislation, and the daybook notes on them seemed to lack the apparent objectivity of the purely descriptive notes on Last Tango in Paris. As Sara E. Shaw notes in her article on the concept of policy-as-discourse, "groups of statements within any discourse that refer to the same topic, have a certain coherence and can therefore represent a particular reality of the world". ${ }^{67}$ The notes in the Chief Censor's daybook display a certain perception of cinema and the perceived value of different types of films, which contrasts markedly with the stated commitment to objectivity in Tunnicliffe's responses to correspondence and other public statements. Thus the daybook notes can be seen as representing a different set of "discursive units" and a different perception of the censorship process from more public statements such as the Chief Censor's responses to correspondence from members of the public. ${ }^{68}$ This relates to the different intended audiences, with official correspondence reflecting the way in which censorship rationalisations were expressed publicly, and the internal daybooks, intended for the censors' own use, reflecting aspects of institutional culture which were not revealed to the wider public.

Last Tango in Paris also provides a unique and detailed example of how the same film could be treated differently under different censors and different pieces of legislation, but with similar appeals to normative standards made in justifying the decisions. This makes it difficult to determine how far the change in the film's fate at the hands of the

\footnotetext{
${ }^{67}$ Sara E. Shaw, "Reaching the parts that other theories and methods can't reach: How and why a policy-as-discourse approach can inform health-related policy," Health 14, no. 2 (2010): 208. 68 lbid., 205.
} 
New Zealand censorship authorities was a result of the change in legislation, and how far it was a result of individual agency. Watson and Shuker argue that "it was the Censor, rather than the Act under which he worked, who was responsible for the bowdlerisation of films", evidenced by the fact that Tunnicliffe "pass[ed] more and cut less" than his predecessor Doug McIntosh even before the new 1976 Act came into force in April 1977.69 The significant differences of opinion among members of the Board of Review both times they examined the film suggests that the earlier legislation could have allowed for a film such as Last Tango in Paris to be passed, and that both the Board of Review and Tunnicliffe claimed to be reflecting the views of the public and prevailing community standards when making their decisions. Therefore, the decision to pass the film in 1977 was in part a result of changes in such standards in the preceding few years (or at the very least a perceived change in such standards) rather than a simple case of more liberal censorship legislation allowing a previously banned film to be passed. The way such standards were determined did not always appear to be particularly rigorous or systematic. Tunnicliffe suggested that he gained his view of what community standards were through speaking to a variety of different groups on the subject of censorship (and taking his subjective interpretation of prevailing community standards as leading to censorship decisions that were objective). R.A. Sharpe, meanwhile, suggested in the 1975 Board of Review hearing that Last Tango in Paris could be passed as a test of what community standards actually were. This appears to reflect a significant difference in the idea of the "third person effect" between members of the Board of Review. While "overestimating the effect of media on others may play an important role in the forces underlying a willingness to restrict various types of communication" 70 , Sharpe appeared to believe that such "overestimation" was taking place and that the effect of the film would not be as strong as the other Board members perceived, although he does not provide a clear evidential basis for this - in effect, he argued that passing the film itself would provide such evidence.

As with many cases of film censorship, the case of Last Tango in Paris demonstrates that what is often presented as an objective process is justified and explained through

\footnotetext{
${ }^{69}$ Chris Watson and Roy Shuker, In the Public Good? Censorship in New Zealand (Palmerston North: The Dunmore Press, 1998), 51.

70 Hernando Rojas, Dhavan V. Shah and Ronald J. Faber. "For the Good of Others: Censorship and the Third Person Effect," International Journal of Public Opinion Research 8, no. 2 (1996): 163.
} 
the use of language that is contentious, not clearly defined, and highly subjective. Terms such as "public order and decency" and "undesirable in the public interest" are not defined in the 1961 film censorship legislation, although there was some overt recognition of this, as the Chairman of the 1975 Board of Review hearing A.J. Lloyd Martin acknowledged that they were not defined in law. However, the new 1976 legislation was perceived as a more objective means of censorship, as it removed the so-called "discretionary clause" which had allowed the Chief Censor to make decisions "in his opinion", and was based on the concept of what was "injurious to the public good", with the law "thought to give a measure of direction" on how this was to be determined. ${ }^{71}$ Tunnicliffe made it clear in much of his correspondence in response to complaints about Last Tango in Paris that his decision to pass it was an "objective" one based on the law and not his own personal opinions. However, there was evident tension between this stated view and some of the more overtly "moral" judgements in the daybooks. As Julian Petley notes, the idea of injury or "harm" from films and video is not necessarily more objective than earlier rationales for censorship. ${ }^{72}$ Petley is writing of the censorship situation in the United Kingdom, but similar comments could also be made of the situation in New Zealand after the passage of the 1976 Cinematograph Films Act:

\begin{abstract}
Indeed, it can convincingly be argued that the notion of offence has effectively been collapsed into or elided with the notion of harm, in the hope that the seemingly 'objective' dimensions of the latter will obscure the fact that censure and censorship are simply enforcing what the authorities take to be 'generally accepted standards' which, in a society as diverse, divided and heterodox as that of the UK, must inevitably mean 'officially accepted standards'. Thus 'harm' is interpreted in such a broad way as inevitably to involve the censors in what are essentially moral judgements. ${ }^{73}$
\end{abstract}

The problem of defining the concept of "injurious to the public good" is one that would face various film and video censorship bodies throughout the period examined in this thesis.

\footnotetext{
71 Watson and Shuker, 51.

72 Julian Petley, Film and Video Censorship in Contemporary Britain (Edinburgh: Edinburgh University Press, 2011), 96.

73 lbid., 96.
} 
Mad Max - historical narrative

Despite the fact that Last Tango in Paris was able to get past the censors under the new legislation, films still continued to be banned, and thus were now deemed to be "injurious to the public good". Many of the films banned by the Chief Censor during the late 1970s were minor exploitation films, such as blaxploitation film J.D.'s Revenge (1976), sex comedy The Pom Pom Girls (1976), and biker film The Cycle Savages (1969), whose banning attracted little attention from the public or the media. However, the Chief Censor's refusal to grant a certificate to George Miller's Mad Max in 1979 did not go unnoticed. In fact, it resulted in significant press coverage, attempts by the distributors to have the ban overturned, and illustrated the significance of the climate surrounding gang violence in New Zealand at the time on the process of censorship of a film which depicted gang violence. The first film in a franchise which was recently revived by Miller for the multiple Oscar-winning Mad Max: Fury Road, 1979's Mad Max is set in a dystopian future Australia and stars Mel Gibson in the title role of police office Max Rockatansky. Unlike Last Tango in Paris, Mad Max had not faced widespread censorship issues elsewhere in the world, and its banning in New Zealand illustrates peculiarly local concerns about the film's portrayal of a violent biker gang, demonstrating that censorship can be influenced by historically specific social circumstances rather than simply broader principles. However, other, less historically specific rationalisations for the decision included the film's overall tone, perceptions about its level of cinematic realism, and appeals to third party authorities to support and justify the ban.

Mad Max was initially examined by the Chief Censor on 8 August 1979. The notes in the Chief Censor's daybook taken by Deputy Chief Censor Ainslie Witaszek, while largely descriptive, sometimes betray a negative personal attitude to the film that went beyond the legislative requirements to judge whether it was likely to be "injurious to the public good". After quoting a character who said "Hey l'm not a bad man...I'm sick", Witaszek added the comment "like the script" in parentheses. ${ }^{74}$ Other daybook notes by Witazsek around the same time also reveal similar subjective value judgements. For example, Wes Craven's The Hills Have Eyes (1977), also subject to a ban, is

${ }^{74}$ ADNB 23133 W5730 Box 178 - Daybooks of Chief Censor of Films - 3/8/79 to 18/3/80. 
described as having "no redeeming features - gratuitous violence + anti-social behaviour (of sci-fi mutant deviant!)". ${ }^{75}$ The decision to ban Mad Max was formally recorded in the Chief Censor's Register of Classification Decisions on 9 August 1979, for "violence and anti-social behaviour". ${ }^{76}$ Less than a week before this, on 3 August, there had been a violent gang clash in Moerewa, Northland, considered to be "the most serious incidence of gang violence that the country had experienced to date". ${ }^{77}$ When the appeal against the ban of Mad Max was eventually heard in 1980, the violence in Moerewa was mentioned, in particular one incident that was seen to be similar to Goose's death in the film, and described by Jarrod Gilbert in his history of New Zealand gangs in the following manner:

A police van was set alight and several Stormtroopers [a gang] attempted to throw Senior Sergeant Charles O'Hara, who was already injured, into the fire, yelling, 'Burn the bastard!' As the senior sergeant cried out, 'Mercy, mercy', he was rescued by battered colleagues and firefighters. ${ }^{78}$

The idea that the ban was entirely the result of this similarity is something that has been passed down over time, and is mentioned in online sources such as the film's Wikipedia entry and Internet Movie Database trivia page. However, the archival evidence does not support this claim. The original daybook notes do not single out this scene for special attention in any way; it is only mentioned briefly by the Board of Review in their decision to uphold the ban on the film. In fact the only contemporary mention is in a newspaper article which quotes actor Steve Bisley, who played Goose, as saying that he had "been told that only one bad incident", the death of his character, had "prompted the ban". ${ }^{79}$ While there is no direct evidence that the violence in Moerewa influenced the initial decision to ban Mad Max, it appears that gang violence in general was definitely an issue of concern for the Chief Censor's office at the time Mad Max was banned, as the subject even warranted its own separate file of newspaper clippings. ${ }^{80}$ Also, Tunnicliffe had banned another film which focused upon

\footnotetext{
$75 \mathrm{lbid}$.

${ }^{76}$ ADNB 24958 W5848 Box 40 - Register of Classification Decisions 1979-1980.

77 Jarrod Gilbert, Patched: The History of Gangs in New Zealand (Auckland: Auckland University Press, 2013), 101.

78 Ibid., 100.

79 The Dominion, 7 September 1979.

80 AAAC W4156 Box 2 - Processes and Procedures, Film Content - Violence, Gangs 1979-1983. While this file does include clippings up to 1983, the vast majority are from 1979.
} 
a biker gang, 1968's The Born Losers, in late 1977, a decision which was overturned by the Films Censorship Board of Review in 1978. The Board noted that in the Censor's submissions, "the main objection cited" was "the intimidation of witnesses, the terrorising of the town by the Born Losers, and the showing of the police force in an unfavourable light", with the "general emphasis on brutality and violence...seen as of secondary concern". ${ }^{81}$ The Board did consider "the extent of the "bikie" problem in New Zealand" when coming to their decision on The Born Losers, but felt that because the film "had no social reality in the New Zealand context" and that "the film as a whole was dated and that the script was hackneyed", that it lacked the impact necessary to be considered "to have an injurious effect on the public good". 82 This was in strong contrast to the way in which the Board would view Mad Max.

Gang violence was much more explicitly identified as a major factor in the subsequent re-examination of Mad Max by the Films Censorship Board of Review, after the Chief Censor's original decision was appealed by the film's distributors on 30 August, with a request that the appeal be delayed "until early 1980" as they wished "to have the producer of the film available to attend the hearing". ${ }^{83}$ This request was agreed to by the Films Censorship Board of Review. Accordingly, the Films Censorship Board of Review did not schedule a meeting to examine Mad Max until 29 February 1980. It seems that the Chief Censor's office was unaware of the distributor's request, as Deputy Chief Censor Diane F. Wren expressed her concerns about the time between the original decision and the review in a memo to Chief Censor Bernie Tunnicliffe and her fellow Deputy Chief Censor Ainslie Witasek, arguing that it was an "extraordinarily long delay" and that she did not think that it fulfilled the legislative requirement of holding a review "as soon as practicable". ${ }^{84}$ She suggested that they should perhaps send a letter of protest to the Board of Review, although it is not clear from the archival material what, if any, protest was made - it seems likely that they became aware of the distributor's desire for a delay before the Board of Review hearing.

\footnotetext{
${ }^{81}$ AAAC 7536 W5169 Box 18 - Films Censorship Board of Review - Born Losers 1978-1980. 82 Ibid.

${ }^{83}$ AAAC 7536 W5169 Box 18 - Films Censorship Board of Review - Mad Max 1979-1983. While the letter from Twentieth Century Fox mentions the producer, it was the director George Miller rather than the producer Byron Kennedy who eventually attended the review.

${ }^{84}$ AAAC W4442 Box 8 - Controversial/Interesting \& Some Rejected Films - Mad Max 1979.
} 
The review eventually went ahead on the planned date of 29 February 1980. Unlike the reviews of the ban on Last Tango in Paris, the review of Mad Max took place under the provisions of the 1976 Cinematograph Films Act, which removed allowance for legal counsel for the various parties involved, although a Crown lawyer attended in the role of amicus curiae. ${ }^{85}$ Thus the hearing was less overtly adversarial than had been the case for Last Tango in Paris. At the hearing, evidence was presented by the Department of Maori Affairs, the police, and the film's director George Miller. The Chief Censor was invited to make a submission to the Board, but he did not do so, and did not attend the hearing. ${ }^{86}$ While George Miller argued that his film had not inspired any anti-social behaviour and in fact had "a sobering effect on audiences", Maori Affairs and the police argued that the film displayed gratuitous violence. ${ }^{87}$ These submissions were much more concerned with the overall perceived tone of the film, and the way it portrayed violence, rather than any specific acts of violence in the film. The Maori Affairs submission, described by District Office P. Te Maipi as "prepared by four member [sic] of this Department who have had some experience in our work among gangs", ${ }^{88}$ suggested that the film portrayed "[v]iolence for violence sake", had an "overwhelming pre-occupation with violence", and that it would be "counter-productive to [their] work with gangs". ${ }^{89}$ The police submission, from Chief Inspector lan Lindsay Mills, argued that there had been a change in the nature of gang violence in 1979, moving from "gang versus gang" to "forced confrontations with the Police" and cases of gangs "intimidating members of the general public". He argued that Mad Max "glorifies violence", had a "dominant effect... of continuous violence", and would be likely to "attract the attendance of gang members and those who enjoy violence". ${ }^{90}$

The Board upheld the original decision of the Chief Censor to ban Mad Max, for "its dominant effect and the extent and degree to which and the manner in which the film depicts anti-social behaviour and violence". ${ }^{91}$ They stated that although they "took careful notice" of George Miller's defence of his film, they gave "considerable weight" to the submissions from Maori Affairs and the police and the problems of gang violence

\footnotetext{
${ }^{85}$ AAAC 7536 W5169 Box 18 - Films Censorship Board of Review - Mad Max 1979-1983.

$86 \mathrm{lbid}$

$87 \mathrm{lbid}$.

$88 \mathrm{lbid}$

$89 \mathrm{lbid}$

$90 \mathrm{lbid}$

91 lbid.
} 
which they highlighted. ${ }^{92}$ Board Chairman A.B. Beatson was more candid about the issue of gang violence being the main reason for supporting a ban in the minutes of the Board's meeting, suggesting that "the timing of Mad Max spoke against it", and it "may easily be approved by the Board in the future", but that releasing it at that time "could cause gang troubles which would be injurious to the public good". ${ }^{93}$ Another Board member felt that while the film "might be injurious to a small section of the public" rather than the public as a whole, but that because of gang problems, even such a more limited potential impact was "of concern at the moment". ${ }^{44}$ Several members of the Board disagreed with George Miller's own categorisation of Mad Max as "a stylised fantasy film", with two members arguing that it is "clearly set in the 1980's", one of them suggesting that it also "had something to say about directions and possibilities of society", and another explicitly stating that he "did not see the film as a fantasy". ${ }^{95}$

As Delia Falconer notes, Mad Max received a somewhat mixed response from film critics on its original release, and "few critics were able to describe the "Australianness" of Mad Max in positive terms" ${ }^{96}$ In contrast, the members of New Zealand's Films Censorship Board of Review recognised it as a well-made film rather than simply lowbudget exploitation, and the quality of the film was in fact seen as working against the possibility of it being passed for release. The Board noted that "because of, and not despite the film's excellence, the impact it could have on the audiences at which it was directed, i.e. the younger viewing age group, could well encourage emulation". ${ }^{97}$ This provides an interesting contrast with the case of The Born Losers, where the film's perceived poorer quality was a factor that allowed for it to be passed by the Board due to its resulting lack of impact.

The decision of the Board of Review to uphold the ban was not unanimous, with four voting for a ban and two against it, demonstrating that while the new legislation was intended to give clearer guidance to censorship authorities, contentious films still resulted in divergent interpretations of the law. However, neither of the dissenting

\footnotetext{
92 lbid.

$93 \mathrm{lbid}$.

$94 \mathrm{Ibid}$

$95 \mathrm{lbid}$.

96 Delia Falconer, "'We Don't Need to Know the Way Home": The disappearance of the road in the Mad Max trilogy," In The Road Movie Book, edited by Steven Cohan and Ina Rae Hark (London: Routledge, 1997), 259.

${ }^{97}$ AAAC 7536 W5169 Box 18 - Films Censorship Board of Review - Mad Max 1979-1983.
} 
Board members chose to write a minority opinion, one specifically stating that while "[h]e believed the director's intentions to be honourable and the film to be technically excellent, however in view of the present gang situation, he would not be writing a minority opinion". ${ }^{98}$ In the official decision published in the New Zealand Gazette, Board Chairman A.B. Beatson noted that "[a]fter considerable discussion", the two dissenting members "finally expressed the view that they did not feel strongly enough about it to wish to formally dissent from the decision of the Board". ${ }^{99}$

Section 31 of the Cinematograph Films Act 1976 required that a film not be resubmitted to the Chief Censor for three years after an initial decision had been made, unless it was "resubmitted within that period... in a substantially altered form, or, in special circumstances approved by the Chief Censor, with the prior approval of the Chief Censor". ${ }^{100}$ Distributors $20^{\text {th }}$ Century Fox attempted to get the ban overturned through this clause by submitting a pre-cut version of the film to the Chief Censor. This version of the film was examined by the Chief Censor's office on 19 August 1981, but the daybook notes that it was "not substantially altered with roughly 3 scenes reduced (not deleted)" and a total of two minutes cut from the original 92 minute running time ${ }^{101}$, so the film was not passed for exhibition at this time, perhaps suggesting that the Chief Censor did not believe that the overall impact of the film was reduced by such excisions.

After the three-year period had passed, the uncut version of Mad Max was resubmitted to the Chief Censor. In a file note, Tunnicliffe explained that it was necessary to deal with the film "on the basis of it being a "new" film and not that it has been refused a certificate of approval earlier" and that "a decision must be made in relation to public opinion". ${ }^{102}$ This time, the film was passed with an R18 certificate. The film was again shown to representatives from Maori Affairs and the police, as well as a psychologist from the Department of Education. While two of the four police representatives suggested that the film should remain banned, the other two recommended R18 and R16, and the two Maori Affairs representatives and the psychologist also did not argue for a ban - in fact the psychologist suggested an R13 or R16 certificate as the "violent

\footnotetext{
98 Ibid.

99 Ibid.

100 Cinematograph Films Act 1976, Section 31(1).

${ }^{101}$ ADNB 23133 W5730 Box 188 - Daybooks of Chief Censor of Films - 1/7/81 to 29/10/81.

102 AAAC W4442 Box 10 - Cinematograph Films Board of Review - Mad Max 1980-1983.
} 
episodes [were] not explicit". ${ }^{103}$ The film was again passed uncut with an R18 certificate for home video by the Video Recordings Authority in 1988, and it was not until 2016 that the classification was lowered to R16, when Ngā Taonga Sound \& Vision (formerly the Film Archive) had the film reclassified to screen as part of a season of films previously banned in New Zealand. In contrast to the original classification, the OFLC considered that the film was "considerably dated, which significantly reduces its impact on the viewer". 104

\section{The Films Censorship Board of Review}

In order to analyse the way in which the Films Censorship Board of Review dealt with Mad Max, it is useful to look at some of their other decisions as a means of comparison, particularly in relation to the manner in which they considered the issue of cinematic realism in several different cases. While the Board of Review upheld the Chief Censor's original decision to ban Mad Max, in other cases they demonstrated a more liberal attitude to what constituted "injurious to the public good", and overturned a number of bans put in place by the Chief Censor's office. One film originally banned by Tunnicliffe but passed by the Board was Alan Clarke's Scum, a drama set in a British borstal that was originally made as a BBC TV play in 1977 but banned from broadcast, and then remade as a film in 1979. Deputy Chief Censor Diane F. Wren had written to Mike Bungay, of the law firm Bungay, Greig \& Co., as she was concerned that "what would make this film likely to be injurious to the public good is its degree of distortion of the truth relating to institutional realities", and that she felt unable personally to fully assess this but believed that Bungay might be able to since "some of [his] childhood and adolescent years were spent in the "rough and tumble" of East London". ${ }^{105}$ Wren was also concerned about the type of audience that the film would attract, and in forwarding Bungay's reply to the other two censors, stated that "the nature of the title is not such as to attract, on title alone, "thinking" people, and

\footnotetext{
103 Ibid.

104 Office of Film and Literature Classification online database, http://www.classificationoffice.govt.nz/DDA/Pages/Screens/DDA/WelcomePage.aspx. ${ }^{105}$ AAAC W4442 Box 8 - Controversial/Interesting \& Some Rejected Films - Scum 1980.
} 
thus it would be viewed by "those least likely to be aware of the latent effect this film would have on their attitudes towards our own penal (-type) institutions". ${ }^{106}$ Wren recommended rejecting the film, and it was banned on 7 March 1980. When the film came before the Board of Review, one member, Mr. B. Lambert, took a similar view to Wren, stating that he "felt that the film would be injurious to the public good if it created a false impression of prisons", but that if it was accurate, "he would approve of its exhibition". ${ }^{107}$ However, the Board overall considered the film to be of serious intent, with "value for the more sophisticated viewer" and that "any detrimental effect its release could have would be outweighed by the advantages to be gained from its being made available in New Zealand". ${ }^{108}$ It was passed by the Board uncut with an R20 certificate; their official decision stressing that it "did not exploit violence for its own sake but portrayed facilities and incidents accurately". ${ }^{109}$ This contrasts rather markedly with the way in which the perceived level of realism in Mad Max worked against the film, as the potential connection with New Zealand's social reality was seen as liable to be "injurious". Conversely, when the Board overturned the Chief Censor's ban on Australian exploitation film Turkey Shoot, another film with a post-apocalyptic setting, a few years later, the film's lack of recognisable reality was given as a reason to pass it, demonstrating that in this case the Board was operating on a similar rationale to when it passed The Born Losers:

Having regard for the futuristic environment in which the film takes place, the variety of weaponry used and the portrayal of various methods of violence; it would be difficult if not impossible to imitate the methods depicted. Accordingly it was felt that the film could not be classed as being injurious to the public good. ${ }^{110}$

In another case, the Board overturned a ban of the Canadian film Class of 1984 subject to several cuts for violence, suggesting that they regarded violence perceived to be gratuitous as injurious to the public good - the cuts required included "the explicit depiction" of one killing and "the explicit killing of a gang member in a petrol fire". ${ }^{111}$

\footnotetext{
106 Ibid.

107 AAAC 7536 W5169 Box 18 - Films Censorship Board of Review - Scum 1980-1981.

108 lbid.

109 AAAC W4442 Box 10 - Cinematograph Films Board of Review - Scum 1980.

110 AAAC W4442 Box 10 - Cinematograph Films Board of Review - Turkey Shoot 1982.

111 AAAC W4442 Box 10 - Cinematograph Fllms Board of Review - Class of 19841983.
} 


\section{Mad Max - analysis}

Mad Max's fate at the hand of New Zealand film censorship authorities provides a detailed example of the way in which censorship decisions were undertaken and rationalised often went far beyond a film's manifest content. The censorship process is frequently a case of competing discourses, what Des Freedman describes as "ideological legitimation", with varying degrees of reference to the actual film itself, media policy implementation being not simply "mechanical or administrative", but a "divisive arena". ${ }^{112}$ There is little specific reference to the details of specific acts of violence by the various parties involved in the censorship process, particularly in the case of submissions by Maori Affairs and the police - the latter largely focusing on the gang violence with which they had to deal, rather than the violence actually depicted in the film.

As the specific details of the film's manifest content were not often addressed, much of the competing discourse focused on the film's tone and the way in which it presented violence. While director George Miller considered the film's violence to be "sobering", representatives from Maori Affairs and the police felt that overall effect was one of violence, even though episodes of violence are separated by non-violent scenes which advance the plot and are dialogue-driven. In fact, the sequel Mad Max 2 (1981) (also known as The Road Warrior), is arguably more focused on "continuous violence" than the first film, as the plot is simpler and the action scenes longer and more elaborate. However, Mad Max 2 was passed uncut in New Zealand in 1982 with only an R16 rating. This is perhaps because Miller succeeded more in creating a "stylised fantasy film" with the sequel. In the first film, society "in the form of the very recognisable 1970 s suburban coastal lifestyle enjoyed by Max, Jess, and Sprog, is directly under siege"113, and recognisable elements of present-day civilisation such as the police and the media are still present. Mad Max 2 is far less realistic and more obviously fantasy and a fable - the mise-en-scène is a constructed post-apocalyptic world with no traces of prior civilisation left, and the use of opening and closing narration sets up Max as far more of a mythic and heroic figure than the way he is presented in the first film. The strong

\footnotetext{
112 Freedman, 3.

113 Falconer, 257.
} 
reaction on the part of New Zealand censors to the first film also may have been a result of its moral ambiguity - it is "preoccupied with a sense that its characters' motives are "contaminated"'114, while the sequel "offers a strong distinction between "good" and "evil" characters". ${ }^{115}$ As Adrian Martin suggests, it is "easy to forget that the inaugural film's discourse on heroism pretty much amounts to a few lines from Max's police boss, Fifi", whereas the sequel addresses the theme much more explicitly. ${ }^{116}$

One notable aspect of the Board of Review hearings was the near unanimous recognition that Mad Max was a well-made film which could not be easily dismissed as low-budget exploitation. However, the quality of the film, and the fact it was regarded as being well-made, actually worked against it, as it was thus perceived as having a potentially greater negative effect on audiences than films of lower quality. Mad Max was also seen as "realistic" and thus more directly relatable to people's actual lives, and thus perceived as more likely to harm the general public. Gwyn Symonds suggests that media portrayals of violence can be seen as a continuum, "from the indexical to the most stylised", and that "[a]ssessing the degree to which viewers and readers react with a visceral response to violence on the screen or page depends on how authentic or realistic they perceive it to be."117 While Mad Max is far from the documentary-style violence that Hallam and Marshment identify in films such as Henry: Portrait of a Serial Killer"118, they note that in such films "the characters in these films seem to lack narratively adequate motivations for the violent acts they commit", "events just happen", and there is an "ethical vacuum". ${ }^{119}$ Such a situation also exists to some extent in the morally ambiguous world of Mad Max. As Falconer notes, the police officers in the film "seem to be as interested in the pleasures of fast

\footnotetext{
114 lbid., 258.

115 Ibid., 261.

${ }^{116}$ Adrian Martin, The Mad Max Movies (Sydney: Currency Press, 2003), 15.

117 Gwyn Symonds, The Aesthetics of Violence in Contemporary Media (New York: Continuum, 2008), 2.

118 Henry: Portrait of a Serial Killer was banned in New Zealand in 1992, and is discussed in the chapter on Jane Wrightson's tenure as Chief Censor.

119 Julia Hallam and Margaret Marshment. Realism and popular cinema (Manchester: Manchester University Press, 2000), 225.
} 
driving, car maintenance, mateship and leather as in the pursuit of justice" and "seem to embody a reactive masculinity, rather than any clear notion of the law". ${ }^{120}$

The decision of the Films Censorship Board of Review also relied significantly on the third-party authorities in the form of the views of representatives from the Department of Maori Affairs and the police. While they had seen the film, much of the content of their submissions was not directly about the film itself, and even when the film was mentioned, it was usually in quite general terms rather than in specific detail. In focusing on this discursive space separate from the manifest content of the film, it is notable that the Board considered these submissions important enough to outweigh the submission of the film's director himself. When the Board itself did refer more directly to the content in their written decision, some of the language used was illdefined and contentious, and it is arguable that in using such language, they misrepresented some aspects of the film. For example, they mentioned the presence of "extreme violence", "graphic detail" in the build up to Goose's death, and describe the deaths of gang members at the hands of Max as "horrific and explicitly portrayed". ${ }^{21}$ However, the film shows very little explicit violence. For example, the death of Johnny the Boy at the end of the film occurs offscreen, and gang leader Toecutter's death under the wheels of a truck is shown briefly and in a long shot rather than graphic close-ups. Such a strong reaction to the film is perhaps a result of Miller's skill as a filmmaker. As Meaghan Morris argues in discussing the film, viewers often remember more violence than is actually present on screen, which can result from "any cleverly edited action scene that works more by suggestion than showing; our imagination excessively completes the scene." ${ }^{122}$ Adrian Martin further elaborates on this idea:

Experience shows that the impact of moments of screen violence or shock can never be restricted to merely visible effects of staging and timing.....In the case of Mad Max, many have testified that its violence is completed in the mind and expanded in the memory, to the extent that they swear they saw things on screen that, literally, they never did. ${ }^{123}$

\footnotetext{
120 Falconer, 258.

121 AAAC 7536 W5169 Box 18 - Films Censorship Board of Review - Mad Max 1979-1983.

122 Meaghan Morris, Identity Anecdotes: Translation and Media Culture (London: SAGE Publications, 2006), 82.

123 Martin, 24-25.
} 
Tobe Hooper's The Texas Chain Saw Massacre (1974) also received a ban in the United Kingdom for many years for a similar reason. James Rose notes that when The Texas Chain Saw Massacre originally came before the British censors, "[w]orking together, the editing team of distributor and censor soon realised that the film was, to some extent, censor-proof because it was not individual scenes that needed exorcising but the overarching feel of the film." ${ }^{124} \mathrm{It}$ is notable that no cuts were ever suggested by New Zealand censors as a means of passing Mad Max for public exhibition, and when a cut version was submitted in 1981, it was considered to be "not substantially altered" despite the reduction of some violent scenes, and thus not eligible for re-classification within the three year period set out by the Cinematograph Films Act 1976.

While the way in which censorship decisions regarding Mad Max display a number of rationalisations common to many of the films I have examined in this thesis, such as judgements about quality and cultural importance, appeals to third party authorities, and perceptions regarding the film's level of "realism", the film was a unique case in New Zealand censorship history in that probably the most significant factor in the decisions by both the Chief Censor and the Board of Review to ban the film was the sociocultural context at the time of the film's initial release in 1979. This is partly a case of the film's "realism" being seen in a negative light, but it was much more specific than that, as gang violence was a more prominent issue in New Zealand than it had perhaps ever been before, and it seems that in this case, the unfortunate timing of Mad Max's release was the most significant factor which resulted in its initial ban.

\section{Angel Mine and Goodbye Pork Pie - historical narrative}

While the case of the ban of Mad Max demonstrated a uniquely New Zealand case of censorship, the specifically local dynamics of the censorship process are even more evident in the case of locally produced films such as Angel Mine and Goodbye Pork Pie. Prior to 1976, New Zealand-made feature films were extremely uncommon. Indeed, during the 1950s and 1960s, only four locally produced feature films were

124 James Rose, The Texas Chain Saw Massacre (New York: Columbia University Press, 2014). 
released, three directed by John O'Shea, and Michael Forlongs's National Film Unit docudrama Journey for Three (1950), which was released as part of a double feature in the United Kingdom. ${ }^{125}$ However, with the success of Sleeping Dogs (1977) and the creation of the New Zealand Film Commission in 1978, local film production became much more frequent. Like the case of Mad Max, the censorship of Angel Mine also illustrates the importance of institutional factors external to the Chief Censor's office itself - the importance of the views of the police and Department of Maori Affairs in the instance of Mad Max, and the post-classification intervention by Minister of Internal Affairs Alan Highet with Angel Mine. More so than overseas films, these local films demonstrate in more detail Annette Kuhn's conception of censorship as not simply "a one-way street, something that is done to films" by censorship authorities. ${ }^{126}$ These case studies also raise more general themes related to the censorship process, with issues of perceived tone being a factor in both decisions, and in the case of Goodbye Pork Pie, the film's level of cinematic realism being a factor as it had been with Mad Max.

Angel Mine was the debut feature of director David Blyth, later notable for such films as New Zealand's first local horror film, Death Warmed Up (1984), and Bound for Pleasure (2004), a documentary on dominatrices in Auckland. Stacey Abbott argues that a common theme in Blyth's career has been a desire "to explore life on the margins of acceptable society while offering a severe critique of mainstream culture". ${ }^{127}$ Blyth had previously shot a black-and-white experimental film called Circadian Rhythms (1976), which mixed Bunuelian surrealism with explicit nudity. Angel Mine continued in much the same vein, albeit with a progression to feature length and colour. Blyth was aware of the practicalities of the censorship process in relation to screening a film in New Zealand cinemas, and in a letter dated 18 September 1978, he wrote to the Secretary of the Films Censorship Board of Review, Brian Fletcher, regarding the classification of his film Angel Mine. Blyth noted that he was "committed to a middle October release date" and was concerned about "possible

\footnotetext{
125 Simon Sigley, "Rites of Passage in Post-Second World War New Zealand Cinema: Migrating the Masculine in Journey for Three (1950)." In New Zealand Cinema: Interpreting the Past, edited by Barry Keith Grant, Alistair Fox and Hilary Radner (Bristol: Intellect, 2011), 169.

${ }^{126}$ Annette Kuhn, Cinema, censorship, and sexuality, 1909-1925 (London: Routledge, 1988), 4.

127 Stacey Abbott, "The Nightmare within the Everyday: The Horrific Visions of David Blyth." In New Zealand Filmmakers, edited by lan Conrich and Stuart Murray (Detroit: Wayne State University Press, 2007), 336.
} 
censorship difficulties with the Chief Censor", and asked if the Board of Review could meet "earlier than is currently being considered" if he did face censorship difficulties. ${ }^{128}$ According to a file note by Fletcher, Blyth also telephoned the Films Censorship Board of Review and indicated that prior to a formal submission for classification, Angel Mine had been viewed by Chief Censor Bernard Tunnicliffe. Fletcher indicated that this was "not a final version", and that Tunnicliffe had "given indication of which parts may cause problems" to Blyth. ${ }^{129}$ The Chief Censor's daybook contains notes of this examination on 8 September 1978, with a note by Tunnicliffe that this constituted an "unofficial review only". ${ }^{130}$ The scenes identified as "obvious problem areas" were an explicit sex scene and a parody of a television commercial that Tunniclife argued could be seen to "strongly imply sodomy" between two men. ${ }^{131}$ In a letter to all members of the Board of Review dated 22 September, Fletcher indicated that Blyth's film was due to be released on 19 October, but as the Board was not due to meet again until 27 October, an earlier meeting of 9 October had been agreed to if Blyth received the "unfavourable decision" from the Chief censor which he feared. ${ }^{132} \mathrm{~A}$ file note from the same day, also by Fletcher, is more candid, suggesting that Blyth "made aspersions on Tunny's [Tunnicliffe's] character" but that Fletcher tried to assure Blyth that Tunnicliffe was fair and impartial. ${ }^{133}$

Fortunately for Blyth, the "unfavourable decision" did not eventuate, and Angel Mine was passed uncut with an R18 certificate, albeit on 18 October 1978, only one day before its planned release date. Perhaps the most notable aspect of this decision, and the most remembered aspect of its classification today, was the unusual censor's note which accompanied the classification, "Contains punk cult material". ${ }^{134}$ Blyth argued at the time that this was misleading, as the film "is not about punks", but that the Chief Censor "pinned this obscure note... because to a man of his years, punk means bad. He thought "Angel Mine" was subversive". ${ }^{135}$ A letter from F. McDonald, a doctor at Auckland's Carrington Hospital, noted that he had attended the Auckland premier and

\footnotetext{
${ }^{128}$ AAAC 7536 W5169 Box 18 - Films Censorship Board of Review - Angel Mine 1978-1979. 129 lbid.

130 ADNB 23133 W5730 Box 173 - Daybooks of Chief Censor of Films - 4/7/78 to 23/11/78.

131 Ibid., AAAC W5169 7536 Box 18 - Films Censorship Board of Review - Angel Mine 1978-1979.

132 AAAC 7536 W5169 Box 18 - Films Censorship Board of Review - Angel Mine 1978-1979.

133 lbid.

${ }^{134}$ ADNB 23133 W5730 Box 173 - Daybooks of Chief Censor of Films - 4/7/78 to 23/11/78.

135 The Dominion, 13 December 1978.
} 
the 18 and 19-year-olds who were there "resented the censor's allusion to "punk cult material". ${ }^{136}$ This censor's note also gave those opposed to the film something to latch on to in their complaints. For example, a letter to Minister of Internal Affairs Allan Highet by Mr. J.F. Pellew, who identified himself as a member of the Society for the Promotion of Community Standards, argued that Angel Mine "contains offensive and depraved punk cult material", with no indication that he had actually seen the film. ${ }^{137}$ Newspaper coverage also sometimes uncritically accepted the censor's note as an accurate description of the film, such as an article in the Dominion of 13 December 1978 entitled 'Punk cult movie labelled 'sick", which described the film as "[t]he New Zealand-made punk cult movie "Angel Mine"”. 138

However, the Chief Censor's daybook suggests that the "punk cult" label was perhaps more thoughtful than it was perceived to be, even though the intended meaning was unclear to both Blyth and the public at large. The initial intended censor's note by Diane Wren was "A New Zealand Punk Film", but this is crossed out in the daybook and was replaced with "Contains Punk Cult Material" by Tunnicliffe. This is followed by some additional information written by Wren:

Pseudo-explanation of "punk" cult. The "sterility" of $20^{\text {th }}$ century life results in emergence of animal instincts of personality. Punk $=$ rebellion against monotony of $20^{\text {th }}$ century values. Rebellion against monochromatic life. ${ }^{139}$

Thus, while Blyth believed that the censor's note was "[i]n a way...a judgment of the film and not a warning", ${ }^{140}$ the daybook suggests it was instead a genuine attempt to reflect the unusual content of the film that did not come across clearly and led to a degree of misunderstanding on the part of the censors. The film did not follow typical filmic conventions of narrative and character, and despite its tagline description as "New Zealand's own erotic fantasy", was largely a "surreal foray into the blurred distinction between dream and reality" 141 rather than a film intended to sexually arouse the viewer.

\footnotetext{
${ }^{136}$ AAAC 7536 W5169 Box 18 - Films Censorship Board of Review - Angel Mine 1978-1979.

${ }^{137}$ AAAC 7536 W5169 Box 18 - Films Censorship Board of Review - Angel Mine 1978-1979.

138 The Dominion, 13 December 1978.

${ }_{139}$ ADNB 23133 W5730 Box 173 - Daybooks of Chief Censor of Films - 4/7/78 to 23/11/78.

140 Sunday News, 22 October 1978.

141 Abbott,.338.
} 
While the aspects of the censorship process occurring before Angel Mine's release took place outside the wider public area, after its release it was the subject of a significant amount of controversy. Much of this centred around the fact that it had received over half its approximate budget of $\$ 60,000$ through public funding specifically, \$6000 from the Queen Elizabeth II Arts Council, and \$25,000 from the Interim Film Commission. ${ }^{142}$ Allan Highet, the Minister of Internal Affairs, defended the grants given to the film, arguing that the Film Commission and Arts Council were "properly carrying out the functions for which they were established" in helping to fund the film, and that [i]t is perhaps inevitable that in pursuing their objectives both bodies are likely to provoke criticism from some members of the public". ${ }^{143}$ However, Highet became significantly involved in the controversy surrounding Angel Mine when he publicly expressed his personal views on the film. An undated Internal Affairs file note indicates that Highet "has seen Angel Mine and was not amused", since it "seems to have everything most likely to offend the community standards lobby". ${ }^{144}$ An article from the Dominion of 10 November 1978 entitled 'Government backed film shocks Highet' noted that he considered scenes from the film "pornographic", and that he desired "extra powers to deal with such films". ${ }^{145} \mathrm{It}$ is unclear exactly what parts of the film concerned Highet, as a later file note simply states that "[c]ertain scenes in the film disturbed him enough to ask the Department to carry out a review of the censorship provisions of the [1976] Act". ${ }^{146}$ Considering that Highet used the term "pornographic", it is possible that he objected to a scene in the film in which the central couple visit an adult cinema and watch what appears to be an unsimulated sex scene, which was far more explicit than anything that had previously been passed in New Zealand, even in other films which were highly controversial for their sexual content such as Last Tango in Paris. The SPCS, which had been responsible for stirring up much of the controversy around the film, described this in their newsletter as "an

\footnotetext{
142 AAAC 7536 W5169 Box 18 - Films Censorship Board of Review - Angel Mine 1978-1979. The Interim Film Commission Funding constituted $\$ 4000$ "to assist the producer with music, sound transfers and limited editing", $\$ 16,000$ for post-production, and $\$ 5000$ for marketing. 143 lbid.

144 AAAC 7536 W5084 Box 44 - Chief Censor and Departmental Responsibility - Review of Censorship Provisions 1981-1982.

145 The Dominion, 10 November 1978.

${ }^{146}$ AAAC 7536 W5084 Box 44 - Chief Censor and Departmental Responsibility - Review of Censorship Provisions 1981-1982.
} 
unbelievable grotesque nude intercourse scene which appeared to be a live sex act". 147

Highet expressed similar views in correspondence in response to complaints he received about the film, in one letter of 2 February 1979 stating that he had "become increasingly concerned about the standard of films being shown in New Zealand", and that he had "asked my Department to draft proposals for amendments to the present legislation which might ensure it remains more in line with public feeling". ${ }^{148}$ However, other correspondence demonstrated that he held somewhat conflicted views. In a letter to Rev. C.W. Haskell dated 16 January 1979, Highet argued that while he "personally found aspects of this particular film distasteful", "[i]t can be argued" that the film is a satire, and that:

I do not accept that in a democratic society such as our own it is possible to impose a system of censorship which prevents the majority of the population from viewing a film, which has been deemed by the censor not to be injurious to the public good, on the grounds that the film could have an injurious effect on a tiny minority of the populace..$^{149}$

Several years later during a speech to the Society for the Promotion of Community Standards, Highet revealed that he had actually talked with David Blyth about his film, and made a strong statement in favour of artistic freedom:

Artists will explore all facets of human experience and we may not like the results. A short time ago I had the opportunity of having a long talk with one of our younger film makers, David Blyth. You may remember that he made a film "Angel Mine" I saw this film and was a little shocked at what I saw....You may recall the opposition to the work of Stravinsky, Picasso and Epstein; society has not collapsed. Remember also Shakespeare and Colonel Bowdler. Bowdler and also, hopefully, his ideas are dead. Let them rest in peace..$^{150}$

Despite his change of heart regarding Angel Mine, Highet's planned review of the censorship legislation did still go ahead, with a review committee comprised of Chief Censor Bernard Tunnicliffe, Deputy Chief Censor Ainslie Witaszek, and several officials from Internal Affairs. The committee noted that Highet had "asked the Department to draft amendments to the Cinematograph Films Act 1976 that would enable the Films Censorship Board of Review to consider more of those films which

\footnotetext{
147 Newsletter No. 34, Society for the Promotion of Community Standards, June 1980.

148 AAAC 7536 W5169 Box 18 - Films Censorship Board of Review - Angel Mine 1978-1979.

149 lbid.

150 AAAC 7536 W5084 Box 26 - Correspondence with the S.P.C.S. 1982-1994.
} 
are a cause of community concern". ${ }^{151}$ However, the committee did not consider that the Minister lacked sufficient powers to call a film in for review "if he is satisfied that further exhibition of a film is likely to be injurious to the public good", and did not recommend any changes to the legislation. ${ }^{152}$ The committee also discussed other more general matters such as the purpose of film censorship, and their stated views on the matter display a recognition of the level of subjectivity in the censorship process not always evident in the justification of individual censorship decisions:

The purpose of film censorship is to exclude from public exhibition those films that in the Chief Censor's opinion are injurious to the public good. He is not the guardian of public morality, although many correspondents view him in this light, and judge him accordingly. To help him to decide whether or not a film is injurious to the public good, s.26 of the Act sets out guidelines. However, his final assessment can only be a subjective one, although the acceptability of his decisions can be measured in the number of critical letters received, and by the number of critical comments made to him when he is addressing groups. ${ }^{153}$

In the event, Highet's concerns over Angel Mine did not lead to any immediate tightening of film censorship provisions in New Zealand. There was an amendment to the 1976 legislation with the Cinematograph Films Act 1980, but this was largely to remove certain licensing requirements for film exhibitors, and made no changes to the censorship provisions already in place.

Another locally produced film, Goodbye Pork Pie, was much less confronting in terms of its content than Angel Mine, aimed at a much wider audience. While it was never in question of being banned or resulting in ministerial intervention, its censorship history in New Zealand demonstrates the degree of negotiation that could occur between New Zealand filmmakers and the Chief Censor's office, as well as the way in which censorship considerations could become a significant part of the production process. Geoff Murphy's first major feature film, Goodbye Pork Pie was significant as being both locally produced and a commercial success "[a]gainst the backdrop of a previously moribund film industry" in New Zealand. ${ }^{154}$

\footnotetext{
${ }^{151}$ AAAC 7536 W5084 Box 44 - Chief Censor and Departmental Responsibility - Review of Censorship Provisions 1981-1982.

152 Ibid.

153 lbid.

154 Jonathan Rayner, "Embodying the Commercial: Genre and Cultural Affect in the Films of Geoff Murphy." In New Zealand Filmmakers, edited by lan Conrich and Stuart Murray (Detroit: Wayne State University Press, 2007), 154.
} 
On 16 June 1980, Goodbye Pork Pie was first examined by the Chief Censor of Films, Bernard Tunnicliffe, and was given an indicative classification of R16. ${ }^{155}$ This was not formally recorded in the Chief Censor's Register of Classification decisions. A note in the Chief Censor's daybook indicates that producer Don Blakeney came and discussed this classification with Tunnicliffe two days later. This was followed on 2 July by a lengthy letter from Blakeney to Tunnicliffe, in order to "explain more cogently [his] reasons for believing the film should have a GA Certificate". ${ }^{156}$ Blakeney argued that unlike many New Zealand film productions, Goodbye Pork Pie was made with commercial success in mind, and "aimed at the main cinema going audiences - mid teens to mid twenties". Due to this focus on gaining a wide audience, Goodbye Pork Pie was "not the film Geoff Murphy most wanted to make", but was intended instead to "give him an opportunity to display his particular talent for action, humour and stunts". ${ }^{157}$ Blakeney stressed the level of self-censorship which had occurred during the film's development, noting that "both the film-makers and the Film Commission considered the question of censorship more fully at the script development stage". ${ }^{158}$ Further detailing the intentions of script changes, Blakeney notes:

\footnotetext{
Although the quality of the script was the main consideration in developing the final script, censorship came up from time to time and modifications made accordingly. In retrospect, it is interesting to reflect on the changes that took place in terms of story, incident, characterisation, etc, and in most cases changes aimed to improve the script tended to strengthen the case for a general certificate. ${ }^{159}$
}

Significant changes which Blakeney identifies are removing a scene in which the main characters sell marijuana to fund their journey as it was considered "out of character", and "[a]ll strong swearing...eliminated leaving only slang". ${ }^{160}$ Blakeney also argued that the lack of realism meant a less restrictive certificate was appropriate, as the film "is not intended to depict events which taken as a whole could reasonably be expected to happen", and "[i]t is entertainment not social realism". ${ }^{161}$

\footnotetext{
155 ADNB 23133 W5730 Box 181 - Daybooks of Chief Censor of Films - 5/3/80 to 16/7/80.

${ }^{156}$ ADMA 22513 W5652 Box 13 - Goodbye Pork Pie 1980.

157 Ibid.

158 lbid.

159 lbid.

160 lbid.

161 lbid.
} 
However, Tunnicliffe was not entirely persuaded by these arguments. Goodbye Pork Pie was re-examined on 15 October, and even with a reduced running time after some cuts had been made by the filmmakers, it was given an R13 classification. ${ }^{162}$ Tunnicliffe later explained his decision in response to a letter from a member of the public concerned about the "[b]ad language", drug use and "total lack of respect for authority" in the film. ${ }^{163}$ In his reply dated 5 March 1981, Tunnicliffe argued that he held different personal and professional views "even if at times they become difficult to separate", and that he largely agreed with the correspondent, stating "I am told it is a fun film, good for all the family", and that he had "the feeling that I was expected to classify this film in a general exhibition category but I did not and still do not see it as such". ${ }^{164}$

Despite the cuts made to the film and the lower censorship classification of R13 rather than R16, Goodbye Pork Pie, while a box-office success, was not without some minor controversy among the wider public. Some newspaper articles suggested that the film inspired criminal activity, such as a Dominion article from 2 July 1981, which reported that "two youths" claimed that after seeing the film, they "decided to steal a yellow mini and attempt to drive the length of the country". ${ }^{165}$ However, other coverage emphasised the box-office success of the film, as well as stressing the entertainment value and lack of realism. For example, an editorial in the Northland Times arguing that "[o]nly the mentally unbalanced could take seriously its unreal situations and exaggerations". ${ }^{166}$ Even Prime Minister Robert Muldoon approved of the film, stating that he did not think that it glamourised lawlessness and "was too obviously lighthearted and a fairy story". ${ }^{167}$ While not inspiring anywhere near the level of correspondence to the Chief Censor as overseas films such as Life of Brian or I Spit on Your Grave, Goodbye Pork Pie nevertheless prompted enough of a response that that Deputy Chief Censor Ainslie Witaszek noted on one of the letters received, dated 12 March 1981, that the Chief Censor's office "should contemplate a PORK PIE file very soon". 168 While the film's producers had expected a GA certificate, some

\footnotetext{
162 ADNB 23133 W5730 Box 183 - Daybooks of Chief Censor of Films - 17/7/80 to 23/10/80.

${ }^{163}$ AAAC W4442 Box 8 - Censorship of Cinematograph Films in NZ - Goodbye Pork Pie 1980-1983.

164 Ibid.

165 The Dominion, 2 July 1981.

166 Northland Times, 30 March 1981.

167 The Dominion, 17 March 1981.

${ }^{168}$ AAAC W4442 Box 8 - Censorship of Cinematograph Films in NZ - Goodbye Pork Pie 1980-1983.
} 
correspondents found the R13 too lenient. For example, Mr. J. Boyland wrote on 10 March 1981 opining "[h]ow can such a film be classified as an R13?", to which Tunnicliffe replied that the contentious elements such as sex and language "are not the complete film", that there are many books with much stronger content. ${ }^{169}$ Another letter from Mr. A. Coates expressed a similar view. He stated that he was "astounded" by the R13 classification, and complained about "explicit sex", "foul language" and "anti-establishment attitudes and the denigration of authority particularly the police". 170 One correspondent also suggested that the Chief Censor had given the film a lower age classification than it deserved because it was a New Zealand made film, an accusation which Tunnicliffe rejected, noting that neither Goodbye Pork Pie "nor any New Zealand production has received special recognition for censorship purposes, simply because it was a "home grown" product."171 Tunnicliffe's response to such correspondence also expressed his mixed feelings about the film. In his response to Coates, he stated that Goodbye Pork Pie "has been looked on and accepted... as a fun film", not appearing to fully accept that assessment himself. ${ }^{172}$ Several years after the film's original release Tunnicliffe stood by his original classification of the film. In a letter dated 15 December 1983 to a correspondent who complained of the allegedly "excessive violence" in the GA rated Merry Christmas Mr. Lawrence (1983) while suggesting that the "innocent, delightful" Goodbye Pork Pie had not been deserving of a restrictive censorship certificate, Tunnicliffe stated:

I was interested in your description of "Goodbye Pork Pie" - innocent, delightful - since I was under the impression that such things as theft, car conversion, drugs, dangerous road practices, sexual intercourse, anti-social behaviour and activities were not generally classed in that category. It seems as though I may have been asleep on more than one occasion and have not really appreciated the fact that times have changed and what, up to now has been considered as largely adult fare, is now innocent, delightful children's fare. It seems too, that some of my counterparts in overseas countries have fallen into the same situation since they too, have placed limitations on who could see the film - certainly not children. ${ }^{173}$

\footnotetext{
169 lbid.

170 Ibid.

171 lbid.

172 Ibid.

173 AAAC W4156 Box 4 - Views Expressed on Specific Films 1976-1983. In the UK, Goodbye Pork Pie actually received an 18 certificate (equivalent to an R18 in New Zealand), which it retains to this day.
} 
This suggests that to some extent, Tunnicliffe had taken an approach to his classification that the subject matter depicted in the film inherently warranted a restrictive censorship certificate, a rare case of manifest content being a significant factor in a contentious censorship decision. This contrasted with the response of the film from much of the general public, and later assessments such as that of Jonathan Rayner, who argued that the protagonists' "ostensibly victimless crimes" which include "shoplifting, drug taking, and stowing away on a ferry", a "cheerful and attractive anarchism"174 rather than the darker undercurrents which Tunnicliffe appeared to detect in the film.

In 1983, there was another attempt by the filmmakers to get a lower censorship certificate with further cuts. On 16 March 1983, Distribution Manager for Goodbye Pork Pie, Kerry Robins, wrote to Tunnicliffe asking him to "reconsider" the R13 rating, and stating that:

[W]e have reduced the footage by about $10 \%$ which we consider to be a significant alteration. We have tried to eliminate obvious areas of contention, such as dope smoking and sex, and consider that the significant change in the national climate since the initial release has shifted in our favour ${ }^{175}$

The reference to a "significant alteration" relates to section 31 of the Cinematograph Films Act 1976, which did not allow for a film to be resubmitted within three years of the initial submission unless it was resubmitted "in substantially altered form". ${ }^{176}$ A file note dated 23 March 1983 noted that this "substantial reduction" was the grounds on which the resubmission was made. ${ }^{177}$ However, it appears that this did not lead to a formal reclassification of the film, and it was not until 15 January 1985, under new Chief Censor Arthur Everard, that the film was reclassified. The same version of the film given an R13 certificate in 1980 was given the unrestricted GA rating that had always been desired by the film's makers. ${ }^{178}$ After legislation instituting formal home video classification in 1987, this rating was converted to an unrestricted ' 13 ' by the Film and Video Labelling Body for video release. Once the ratings for cinema and

\footnotetext{
174 Rayner, 154.

175 AAAC W4442 Box 8 - Censorship of Cinematograph Films in NZ - Goodbye Pork Pie 1980-198.

176 Cinematograph Films Act, Section 31.

177 lbid.

178 ADNB 23133 W5730 Box 215 - Daybooks of Chief Censor of Films - 20/12/84 to 5/7/85.
} 
video were standardised by the Films Videos and Publications Classification Act 1993, this became a PG rating, which the film still retains to this day.

\section{Angel Mine and Goodbye Pork Pie - analysis}

Even more so that overseas films which only involved the New Zealand censorship authorities once they reached these shores, Angel Mine and Goodbye Pork Pie provide clear case studies of how censorship is not simply something imposed on films by censorship authorities, but is a "give-and-take between contending parties". 179 Particularly in the case of Goodbye Pork Pie, censorship considerations were an inherent part of the film production process, illustrating Judith Butler's idea that "censorship is a productive form of power: it is not merely privative, but formative as well". ${ }^{180}$ Thus, censorship is not merely defined as the actions of bodies charged with undertaking official state censorship such as the Chief Censor's office, but is something that has already occurred in the production phase of the film before it has been given a formal censorship classification. While such considerations are part of the process in some of the other films examined in this thesis, the New Zealand censorship context is generally not a serious consideration for non-New Zealand filmmakers, as it is such a small market. However, the cases of Angel Mine and Goodbye Pork Pie in the early years of the revitalised New Zealand film industry seem to be unusual cases even in the local context. The archival material does not suggest that such a back-and-forth process between the filmmakers and the censorship authorities routinely occurred after this up until 1994, and my interviews with succeeding Chief Censors Arthur Everard and Jane Wrightson confirm this view. Everard stated that New Zealand filmmakers did not submit films for classification before completion during his tenure as Chief Censor ${ }^{181}$, and Jane Wrightson stated that the only local film she examined before its formal submission for classification was Once Were Warriors (1994). ${ }^{182}$

\footnotetext{
179 Michael Holquist, "Corrupt Originals: The Paradox of Censorship," PMLA 109, no. 1 (1994): 17. 180 Judith Butler, Excitable speech: a politics of the performative (New York: Routledge, 1997), 133.

181 Interview with Arthur Everard.

182 Interview with Jane Wrightson.
} 
However, as well as this uniquely New Zealand context, the cases of both Angel Mine and Goodbye Pork Pie also demonstrate other aspects of censorship decision-making rationalisation in common with films from other countries. In particular, the perceived tone of each of the two films was a major factor in the discourse surrounding them. If merely focusing on manifest content, it is possible to simply state that Goodbye Pork $P i e$ is a film that contains profanity, drug use, male and female nudity, crime and violence, and may thus seem on the surface to warrant a heavily restrictive classification. Indeed, Tunnicliffe's justification for the R13 rating given to the film is in part a rare appeal purely to manifest content, although his reasoning is somewhat selfcontradictory in that he also suggests that depictions of sex and drug use are "not the complete film", and thus that context is also important. However, the wider discourse of the film demonstrates the importance of perceived tone, as the film was viewed as essentially lighthearted by its makers and much of the viewing public, while Tunnicliffe thought differently. In the case of Angel Mine, Highet's attempted intervention reflects on the issue of whether or not the film can be seen to treat its material seriously or exploitatively, with Highet shifting from viewing it as "pornographic" to regarding it as a sincere attempt at a valid artistic statement. The censor's note about "punk cult material" reflects the way in which unclearly defined and contentious language can be part of a censorship process often presented as "objective". While it can be seen as an attempt to understand the film, it is much less clear than standard censor's warnings such as those about violence or sexual content, and in this case makes the censor's decision appear to be an overtly moral judgement of the film when this was not necessarily intended.

\section{Life of Brian - historical narrative}

In contrast to Angel Mine and Goodbye Pork Pie, the controversy surrounding the release of the third Monty Python film, Life of Brian, in New Zealand was part of a worldwide trend surrounding the film's supposedly "blasphemous" content - it had already faced significant controversy in the United Kingdom and United States in 1979, prior to its release in New Zealand. Both countries saw protests from religious groups, and while the British Board of Film Censors passed it uncut, some local councils chose 
to ban the film. The film was also banned outright in Norway, on the grounds that the Norwegian constitution "declares that religious and minority groups should not be subject to insult"183, which resulted in it being marketed in Sweden as "so funny it was banned in Norway". ${ }^{184}$ The way in which the film's classification was rationalised by the censors demonstrates the way in which certain views were given greater authority and legitimacy, with those seen as lacking in direct personal knowledge of the film being regarded as less worthy of consideration. This case study also raises issues of how the distinction between what is regarded as "injurious" and what is simply "offensive" was negotiated and explained.

Before it had even been examined by Chief Censor Bernard Tunnicliffe, his office had received a number of letters of concern regarding the film and its alleged blasphemy, making appeals both to religion and to censorship law. For example, a letter from the Territorial Commander of the Salvation Army to Tunnicliffe did not make any specific reference to censorship legislation, but instead argued:

For such a film to have the official stamp of approval of the Chief Censor of Films who is a member of the Department of Internal Affairs of the government of a country which is still Christian in tradition, heritage, culture and religion would cause grief and shame to a significant number of its citizens. We realise that this imposes an extra burden of responsibility upon you. We will pray that you may have divine guidance in this important matter. ${ }^{185}$

In contrast, the Women's Division of Federated Farmers explicitly quoted Section 26(2)(d) of the 1976 Cinematograph Films Act, which required the Chief Censor to take into account "[t]he extent and degree to which the film denigrates any particular class of the general public by reference to the colour, race or ethnic or national origins, the sex, the religious beliefs of members of that class", although without reference to any specific details of the film in their call for it to be banned. ${ }^{186}$ This clause of the 1976 Act, and a similarly worded clause of the 1983 Films Act which replaced it, were widely appealed to by those protesting against films such as Life of Brian which were seen to be blasphemous or otherwise religiously offensive. In this instance, it was most likely as a result of a newsletter by the SPCS which suggested that members should write

\footnotetext{
183 Eugene Register-Guard, January 151980.

184 "What did 'Life of Brian' ever do for us?". http://www.telegraph.co.uk/culture/film/6679546/Whatdid-Life-of-Brian-ever-do-for-us.html.

${ }^{185}$ AAAC W4303 Box 5 - 'Life of Brian' (letters of concern) 1980.

186 lbid.
} 
letters to Chief Censor Bernard Tunnicliffe pointing out this clause "and request[ing] that the film be banned". ${ }^{187}$

In response to these early letters of complaint, Tunnicliffe made it clear that the film had not yet been submitted to his office, and while he was aware of "the controversy which has arisen overseas and of the offence the film has given to the feelings and beliefs of some people", he was required to take into account different views on the film, as well as the specifics of New Zealand's film censorship legislation. ${ }^{188}$ In response to one correspondent, he explained that:

[T]here are at least two widely diverging lines of views and opinions, and these will have to be taken into consideration and evaluated by my staff and I, quite apart from all other relevant issues and criteria specified in the statute and which carry equal weight. Only then can a decision be made to either reject or approve the film for showing in this country. ${ }^{189}$

Life of Brian was passed uncut by the film censors on 18 February 1980 in a $35 \mathrm{~mm}$ version, and a similarly uncut $16 \mathrm{~mm}$ version was also passed on 29 September 1980, both with an R16 certificate. Of the three film censors, Chief Censor Bernard Tunnicliffe and Deputy Chief Censor Ainslie Witaszek both supported an R16 rating, but the third Censor, Diane Wren, favouring a GA certificate so strongly that she wrote in the margin of the daybook notes:

This is Tunni [Bernard Tunnicliffe] and Ainslie's decision. Any queries to them re: the film since my "No comment" will be of little use to the public - I mark my dissent ${ }^{190}$

In response to some of the later letters of complaint regarding this decision, Tunnicliffe pointed out that he had consulted a "cross section of people, which included members of the clergy" none of whom found "any reason why the film could not be shown", even though not everyone found the film "to his or her liking". ${ }^{191}$ An Internal Affairs file note, with the comment "not to be made public", provides some detail of the specifics of this consultation, indicating that those who were invited to attend a screening by the Chief Censor were the Bishop of Wellington, a priest in his 30s, the Solicitor General and

\footnotetext{
187 Newsletter No. 32, Society for the Promotion of Community Standards.

188 AAAC W4303 Box 5 - 'Life of Brian' (letters of concern) 1980.

189 lbid.

190 ADNB 23133 W5730 Box 179 - Daybooks of Chief Censor of Films - 3/8/79 to 18/3/80. An addition note in the daybook signed by Ainslie Witaszek on 19 February 1980 confirmed Diane Wren's "strong dissent".

191 AAAC W4303 Box 5 - 'Life of Brian' (letters of concern) 1980.
} 
the Secretary of Internal Affairs. While the Bishop of Wellington "[f]ound the coarse language and nudity unnecessary", he did not consider the film to be sacrilegious or blasphemous in any way. ${ }^{192}$ Unlike the United Kingdom, where films at the time could be banned on the grounds of blasphemy, no such legal provision existed in New Zealand, although the Cinematograph Films Act 1976 did require the censors to consider "[t]he extent and degree to which the film denigrates any particular class of the general public" in various categories including "religious belief". ${ }^{193}$ This file note also indicated that at this early stage, correspondence to the Chief Censor was largely the result of the Society for the Promotion of Community Standards' newsletter, as the letters tended to contain "expressions and quotes" from this newsletter. ${ }^{194}$

After the film had been passed by her office, Deputy Censor Diane F. Wren, who had privately argued for a GA rating rather than an $\mathrm{R} 16$, responded to a letter from the Archbishop of Wellington expressing her dismay at the controversy surrounding the film. She explained:

It is unfortunate that much second-hand publicity has fueled a very controversial fire about the film. If you had seen it I feel sure you would have recognised it for what it is: a piece of satire or, if you will, burlesque. The traditional function of satire or buffoonery is not to lampoon the genuine but rather the affected. And it is the "affected", the non-genuine, that Monty Python ridicules in his [sic] Life of Brian. The butt of his satire is again, traditional; humanity's foibles are shown in various arenas: national; political; in customs and religions. ${ }^{195}$

However, this was far from the end of the matter for the Chief Censor's office. As Watson and Shuker note, the office "received more letters about Monty Python's Life of Brian...than any other film before or since. ${ }^{196}$ In fact, so many were received that Tunnicliffe prepared nine different "form" letters in order to respond to them efficiently. While different in some details, these letters made the same general point - that the film was not as the letter writers had described it, and it was not in any way blasphemous or an attack on Jesus Christ:

The film tends to expose and "send up" the gullibility and the cupidity of people, lampooning them and their hypocritical attitudes, but it does not debase or mock God or Christ, nor does it in our

192 ACGO 8333 IA1W2633 6 Part 1 - Cinematograph Films - Censorship - 'Life of Brian' 1979-1980. 193 Cinematograph Films Act 1976, 26(2)(d). In the UK, Nigel Wingrove's 1989 film Visions of Ecstasy was banned on the grounds of blasphemy, the only film to be subject to this fate.

${ }_{194}$ ACGO 8333 IA1W2633 6 Part 1 - Cinematograph Films - Censorship - 'Life of Brian' 1979-1980.

${ }^{195}$ AAAC W4303 Box 5 - 'Life of Brian' (letters of concern) 1980.

196 Watson and Shuker, 52. 
view denigrate the Jewish people. It may be argued that the film is in bad taste, but this is a factor in terms of the laws under which decisions must be made, I may not take into account. ${ }^{197}$

This suggests that Tunnicliffe made a clear distinction between "injury" and "offence", arguing that while Life of Brian may offend some viewers, this did not make it injurious to the public good.

Many letters of complaint were also written to Minister of Internal Affairs Allan Highet. While it does not appear that he viewed the film himself, Deputy Secretary for Internal Affairs B.C. McLay did view the film and outlined his "personal view" to Highet, arguing that the film "is not a parody of the life of Christ" as some correspondents had categorised it, and that "the storyline is far from obsessed with religious blasphemy", and comments on many other issues such as "politics, feminism, crime, punishment, decadence, and the Romans". ${ }^{198}$ McLay also pointed out that the Minister of Internal Affairs could only act to withdraw a film which had been classified by the Chief Censor if it can be "shown that the film is injurious to the public good", which McLay did not consider "as being the case from the correspondence". 199 Highet appears to have followed this advice, and his replies to correspondence on the subject of Life of Brian show his support for Tunnicliffe's decision, stating that he believed that "the censorship provisions of the present legislation have been fully and fairly considered in the case of this film". 200

As well as individual letters to the Chief Censor and Minister of Internal Affairs, a nationwide petition was organised which called on Highet to exercise the power he had under Section 85 of the 1976 Cinematograph Films Act to halt exhibition of a film and refer it to the Board of Review if he considered that "the further exhibition of the film is likely to be injurious to the public good". ${ }^{201}$ The petition was largely organised through churches, and the standard form for collecting signatures which was copied and distributed nationwide argued that the film "denigrates the Christian public of New Zealand, making an offensive mockery of their religious beliefs, by parodying the birth, life and death of the Lord Jesus Christ". ${ }^{202}$ This petition managed to gather a total of

\footnotetext{
197 AAAC W4442 Box 10 - Censorship - Pressure Groups - Monty Python's Life of Brian 1980-1981.

198 ACGO 8333 IA1W2633 6 Part 3 - Cinematograph Films - Censorship - 'Life of Brian' 1980.

199 lbid.

${ }^{200}$ ACGO 8333 IA1W2633 6 Part 3 - Cinematograph Films - Censorship - 'Life of Brian' 1980

201 Cinematograph Films Act 1976, Section 85.

202 ACGO 8333 IA1W2633 6 Part 4 - Cinematograph Films - Censorship - 'Life of Brian' 1980
} 
12,532 signatures. However, Highet did not consider the petition or the letters of complaint sufficient grounds to stop the film's exhibition, and maintained his view that he was "not satisfied that the continued screening of the film is likely to be injurious to the public good". 203

In early 1981, after the controversy had died down, both Chief Censor Bernard Tunnicliffe and Deputy Chief Censor Ainslie Witaszek wrote detailed replies to letters regarding Life of Brian that provide a revealing insight into the philosophy by which the censor's office operated. Tunnicliffe explained the way in which he interpreted the concept of "likely to be injurious to the public good" in the 1976 legislation:

It has been suggested that the phrase could be interpreted as referring to one person or a small group of individuals but in our view, it is more correctly interpreted as being "the public as a whole" or "the community as a whole", or at the very least the largest part of that public. It is inevitable, therefore, that some of the decisions which we arrive at will be unacceptable either to individuals or to groups of individuals whether they are for more restrictive censorship or for less restrictive censorship or for no censorship at all. 204

Tunnicliffe also explained that the volume of correspondence received was not considered a significant factor in coming to the decision to pass Life of Brian uncut:

In the case of "Life of Brian" the number of letters received was immaterial since many parroted the views or comments expressed by others, both here and overseas, but without any real knowledge of the true content of the film. Even if I had received no letters or even double the quantity I still would have been obliged to make my decision on the film in terms of the legislation and not on the basis of any mail that might or might not arrive. Similarly, if I received a large quantity of mail in support of a film but in terms of the Act I considered the film was injurious to the public good, it would be banned. ${ }^{205}$

In response to a correspondent who thought that the $\mathrm{R} 16$ rating for Life of Brian was overly restrictive, and that the censors may have been swayed towards it by the letters of complaint, Ainslie Witaszek argued that this was not the case, and explained the difficultly of coming to "objective" censorship decisions:

We are expected to exercise the maximum of objectivity possible in such a subjective field, and to resist the urge to impose personal views - ours or anyone else's - in our official decisions. Bearing in mind the potential for variation in the nature of a cinema audience, its constantly

${ }^{203}$ ACGO 8333 IA1W2633 7 Part 6 - Cinematograph Films - Censorship - 'Life of Brian' 1980-1981 ${ }^{204}$ AAAC W4442 Box 10 - Censorship - Pressure Groups - Monty Python's Life of Brian 1980-1981 205 Ibid. 
changing nature from film to film, and what we regard as insufficient feedback from, or knowledge of the detailed viewing preferences of, New Zealand cinema-goers we are well aware we are operating in a very gray [sic] area. I cannot assure you that our decisions unfailingly reflect what is acceptable to the majority of people who see the films we censor. Sometimes we may anticipate the majority, sometimes we may lag behind. 206

Minister of Internal Affairs Allan Highet also reflected on the controversy surrounding Life of Brian in a speech to the Society for the Promotion of Community Standards in 1982, arguing that there were no grounds for him to refer the film to the Board of Review:

Quite apart from the fact that it may again be approved with the same classification, withholding approval cannot be justified unless it is injurious to the public good, and it can hardly be injurious to the public good if it is a popular film and conforms to popular tastes. "Life of Brian" is an example. There were record attendances throughout the country but to a small but vocal section of the community it was offensive or was claimed to be offensive because however sincere, over $95 \%$ of those who wrote to me had not viewed the film. ${ }^{207}$

\section{Life of Brian - analysis}

Perhaps even more than any other film in New Zealand censorship history, much of the discourse around Life of Brian was about an "imagined" version of the film constructed initially by campaigners overseas and repeated by those in New Zealand who wanted the film to be banned. This left the censors in a clearly evident position of frustration, as they could see that much of the controversy had little to do with the actual content of the film. In the case of Life of Brian, the level of discursive legitimacy which the Chief Censor's Office gave to particular viewpoints was directly related to the level of knowledge about the content of the film. As Des Freedman notes in discussing media content policy making and implementation, "media content is subject to a barrage of both formal and informal pressure from governments, judges, political parties, pressure groups and corporations". ${ }^{208}$ However, the "structured power relationships and dominant ideologies in the policy process" 209 meant that since the

\footnotetext{
206 Ibid.

207 AAAC 7536 W5084 Box 26 - Correspondence with the S.P.C.S. 1982-1994.

208 Freedman, 122.

209 Shaw, 201.
} 
censors and the Minister of Internal Affairs both opposed the idea of banning the film, they were in a position to give their own views on the film greater discursive legitimacy. The classification decision for Life of Brian was also legitimised by appeals to third party authorities in the form of a consultation with religious representatives and others, although the archival record suggests that this was rather ad hoc and informal. This consultation also highlighted the distinction between what was seen as "injurious" and what was only "offensive", as some of those consulted felt the film fell into the latter category but not the former.

\section{The emergence of home video}

In the early 1980s, towards the end of Tunnicliffe's tenure as Chief Censor, home video began to emerge more prominently in New Zealand. As Watson and Shuker note, "[t]he removal of import licensing restrictions in December 1980 saw a rapid expansion of New Zealand's ownership and usage of video cassette recorders (VCRs)". ${ }^{210}$ Prior to this, VCRs needed to be privately imported. ${ }^{211}$ Unlike cinema films, films on home video lacked any formal legal censorship at this time, and the early 1980s saw the first significant efforts to try and deal with the issue of home video censorship. Existing film censorship legislation only covered films for public exhibition, and prior to the rise of home video in the early 1980 s, films that had been rejected by the Chief Censor could still potentially be screened if they were shown in private residences rather than public cinemas. For example, in 1978 the Department of Internal Affairs was made aware by J.P. Moodabe of Amalgamated Theatres that a company called Capital Film Services Ltd was hiring out copies of films, including Tobe Hooper's The Texas Chain Saw Massacre, which had been banned by the Chief Censor the previous year, albeit in an already pre-cut version. ${ }^{212}$ Brian Fletcher from

\footnotetext{
210 Watson and Shuker, 63.

211 Jane Bradley and Alastair McKenzie. Video in New Zealand (Wellington: Department of Internal Affairs, 1988), 4.

212 The Chief Censor's daybook (ADNB W5730 23133 Box 168 - Daybooks of Chief Censor of Films $19 / 4 / 77$ to $23 / 8 / 77$ ) notes that the film was "a soft version presumably", which had been "precut at the most likely places for slaughterhouse type activities e.g. hanging bodies on meat skewers, dissection and sausage making". The Censor clearly had not seen an uncut version, since the film does not contain "dissection and sausage making", but based on the daybook description it does appear that
} 
Internal Affairs contacted the company and they confirmed that they did have the film among their inventory, but "that their product is hired only to persons to screen in their own homes and a clause in the hire contact embodies this condition". ${ }^{213} \mathrm{He}$ also noted that Moodabe considered the legal situation to be "an anomaly in the Act which operates unfairly against commercial exhibitors". ${ }^{214}$ However, Fletcher took a different view:

I am of the view that this is not an anomaly. The provision has been embodied in successive statutes concerning film censorship. This would appear to be the first occasion that it has been highlighted. The exclusion covers all non-public screenings in a private residence and not solely films rejected by the Chief Censor. There appears to be no justification for regulating the actions of persons in their own homes unless the public is admitted. ${ }^{215}$

This public/private distinction, and the belief that private viewing should be less restricted than public viewing, carried over into the official discourse surrounding home video in the early 1980s, and would be a key aspect of the debate surrounding home video censorship. In his 1982 speech to the Society for the Promotion of Community Standards, Allan Highet commented on the subject of home video, which had been a concern of the Society:

I have been concerned that some of the films which the Chief Censor has refused approval have become available on video. However, I accept that these video tapes are not for public viewing. If they were, they would come within the provisions of the Cinematograph Films Act. The Government is reluctant to impose greater restrictions on what is viewed in a private residence. ${ }^{216}$

In a briefing to Highet on 4 August 1983, B.D. Fry of Internal Affairs expressed a very similar opinion:

It has been generally accepted that what a citizen does in his own residence is of no concern to others, including the Government, providing such action causes no harm to others. There has been considerable concern expressed in recent years of the increasing intrusion into a citizen's private affairs by agencies of Government. It must also be said that there are a number of activities which, if carried out in, or in view of a, public place, constitute an offence, but if done in a private residence, do not. Any restrictions placed on the viewing of videotapes in a private

the infamous scene in which Leatherface impales a young woman on a meathook had been removed prior to submission. The running time was also listed in the daybook as "75/76 minutes", whereas the full version runs 84 minutes.

${ }^{213}$ ACGO 8333 IAW2633 4 - Cinematograph Films - Illegal Screenings 1977-1980.

214 Ibid.

215 Ibid.

${ }^{216}$ AAAC 7536 W5084 Box 26 - Correspondence with the S.P.C.S. 1982-1994. 
residence could cause some contradictions, in that, although the activity itself is not illegal, the viewing of such acts on videotape may be restricted. ${ }^{217}$

What formal legal censorship of home video that did exist was via customs seizures of videos which they believed could be considered "indecent". B.D. Fry explained the legal situation in a 1981 file note:

The question of whether or not video tapes are included within the definition of the term "document" has been the subject of a legal opinion from Crown Counsel which concludes that tapes are covered. However, there is some doubt and the decision in the case Police $v$ David Leslie Cross, currently being held in the Auckland District Court, should resolve the question. ${ }^{218}$

However, there does not appear to be any further reference to this case in the archival material, and videos continued to be considered "documents" under the Indecent Publications Act until the passage of video censorship legislation in 1987. New Zealand's video industry body, the Video Association of New Zealand, made a submission to the Minister of Justice on 25 March 1983 expressing their concerns over customs seizures, such as lack of clear guidelines for Customs regarding what should be seized, inconsistency of court rulings, and the uncertainty which the existing situation placed upon the video market. ${ }^{219}$ They argued that there was a difference between "private rather than public decency standards", and suggested a regime of self-regulation by the video industry itself, with a separate "suitable body to examine and classify video films referred to it by Customs, the police or video importers or distributors", rather than the courts. ${ }^{220}$ The Government was receptive to the idea of partial self-regulation, and Fiona McGregor, writing in December 1983 for the Secretary of Internal Affairs regarding the 'New Zealand Movie Register', noted that "The Video Association has been having discussions with the Minister of Internal Affairs regarding self-regulation of the video industry for purposes of censorship", and querying whether the video classifications in the booklet were "indicative of this self-

\footnotetext{
217 ACGO 8333 IAW2633 4 - Cinematograph Films - Illegal Screenings 1977-1980. Such a situation would in fact come to pass through some provisions of the Films, Videos, and Publications Classification Act 1993, such as banning "the use of urine" in sexual material, thus making it an activity that was legal to participate in but illegal to view on video.

${ }^{218}$ AAAC 7536 W5084 Box 44 - Chief Censor and Departmental Responsibility - Video Interdepartmental Committee 1982-1985.

${ }^{219}$ AAAC W3628 Box 3 - Chief Censor and Departmental Responsibility - Video Correspondence 1980-1983.

220 lbid.
} 
regulation". ${ }^{221}$ However, it was not until the following year that more significant developments towards video censorship legislation would occur, with the formation of an Interdepartmental Committee between Customs, Justice and Internal Affairs to attempt to find a solution to "the problems relating to the system of dealing with videotapes which may be indecent". 222

\section{Chapter summary}

This chapter has examined several case studies of films which were contentious in censorship terms during Bernard Tunnicliffe's era as Chief Censor, from 1976 to 1984 , as well as examining the censorship history of Last Tango in Paris before Tunnicliffe passed it uncut in 1977. While the decisions of censorship authorities were rationalised in different ways for different films, a number of common themes emerge. Most notably, film censorship in this period often had little to do with the manifest content of the films themselves, and became a contest for discursive legitimacy between the various parties involved in the censorship process, including censors, filmmakers and pressure groups. It is also notable that when a decision was made to ban a film, the rationalisation of the decision was generally much more complex and involved a greater variety of different considerations than when a film was passed for public exhibition - in the cases of Last Tango in Paris and Mad Max, many more factors were evident in the decision-making process than the other films examined in this chapter. During this period, home video had only just started to emerge as a factor influencing the discourse around censorship in New Zealand, but this was to change dramatically during the tenure of Tunnicliffe's successor as Chief Censor, Arthur Everard.

\footnotetext{
${ }^{221}$ Ibid.

222 AAAC 7536 W5169 Box 17 - Chief Censor and Departmental Responsibility - Video Interdepartmental Committee 1983-1987.
} 


\section{Chapter Four: Chief Censor Arthur Everard, 1984-1987}

\section{Chapter overview}

This chapter focuses on the first few years of the reign of Chief Censor Arthur Everard, who took over from Bernard Tunnicliffe in 1984 and very soon found himself embroiled in controversy for his decision to pass Meir Zarchi's film I Spit on Your Grave uncut. Three case studies of film censorship are examined - I Spit on Your Grave and The Driller Killer, both of which were passed uncut, and a 20 minute compilation of violent material from so-called "video nasties" that the Society for the Promotion of Community Standards planned to screen to Members of Parliament, which was banned. As in the previous chapter, the discussion will focus on the way in which these films became sites of contested discursive legitimacy, with particular views granted greater legitimacy and influence than others, as power over media policy implementation tends to be "distributed very unevenly". ${ }^{1}$ In particular, widely varying views between censors and pro-censorship campaigners on the nature of media effects became a contentious issue. This chapter also discusses efforts to deal with the issue of home video censorship, and the legislation to deal with the issue that finally eventuated in 1987. The implementation of this new legislation will be discussed in the next chapter.

\section{Spit on Your Grave and The Driller Killer - historical narrative}

1984 saw several significant changes in the film censorship landscape in New Zealand. There was a new Labour government, and thus a new Minister of Internal

\footnotetext{
${ }^{1}$ Oliver Boyd-Barrett, "Theory in Media Research." In Mass Communication Research Methods: Volume 1, edited by Anders Hansen (Los Angeles: Sage, 2009), 33.
} 
Affairs, Peter Tapsell. The Films Act 1983 also came into force on 1 April 1984, although this did not change censorship practice significantly, and film censorship was still handled by one Chief Censor and two Deputy Chief Censors. However, the most significant change was the appointment of a new Chief Censor, former National Film Unit filmmaker Arthur Everard, who took over the job in late February $1984 .^{2}$ Unlike his predecessor, he had no previous background in film censorship, and he had completed a psychology degree before his 19 years at the National Film Unit. ${ }^{3}$ Interviewed by the Listener nine months into his appointment, Everard displayed a degree of sensitivity to the commercial and artistic concerns related to film censorship, arguing that people are "entitled to make a living" out of films and that they it would be "irresponsible" to ban a film for lacking artistic merit, and that he "acknowledge[d] the freedom of the film-maker to say something even if he hasn't got the technique to say it properly". ${ }^{4}$ During Everard's tenure as Chief Censor, from 1984 to February 1991, home video became much more prominent and widely available in New Zealand, and there was some concern over so-called "video nasties", a term which had become prominent in the discourse around home video in the United Kingdom. The origins of the term are not entirely clear - Martin Barker suggests that it "seems to have been invented by Mary Whitehouse in 1982"5, whereas Kate Egan points out that former British Chief Censor James Ferman dated the term to an earlier Sunday Times article. ${ }^{6}$ However, Barker notes that the key point is that the term "emerged as a press label" in $1982 .{ }^{7}$ The term came to refer to a list of specific films singled out for prosecution for obscenity by the British Director of Public Prosecutions; films that while broadly categorised as "horror" films, "were not predominantly grouped together on the basis of shared formal, thematic and/or structural features", but because they had happened to be released on home video in the United Kingdom in the early 1980 s. $^{8}$ While it can be argued that the term's "relevance and functionality" are very much specific to the

\footnotetext{
2 North \& South, October 1990, 99.

${ }^{3}$ Arthur Everard, https://www.nzonscreen.com/person/arthur-everard/biography.

${ }^{4}$ NZ Listener, 24 November 1984, 19.

${ }^{5}$ Martin Barker, "Nasty politics or video nasties?" In The video nasties: Freedom and censorship in the media, edited by Martin Barker (London: Pluto Press, 1984), 8.

${ }^{6}$ Kate Egan, Trash or treasure? Censorship and the changing meaning of the video nasties (Manchester: Manchester University Press, 2007), 15.

${ }^{7}$ Barker, "Nasty politics or video nasties?", 8.

${ }^{8}$ Egan, 3.
} 
UK context ${ }^{9}$, the term did also enter the discourse around censorship in New Zealand in the 1980s, and two of the "video nasties" which had been most prominent during the original moral panic in the United Kingdom, Abel Ferrara's The Driller Killer and Meir Zarchi's I Spit on Your Grave, were passed uncut for cinema release by Everard. Of the two films, I Spit on Your Grave generated much more controversy in New Zealand for its portrayal of sexual violence than The Driller Killer did for non-sexual violence. This section, on the New Zealand censorship history of I Spit on Your Grave, highlights several important themes. One of the most prominent is the issue of media effects, and the strong divergence in views on the topic between censorship authorities and those who viewed the censor as too lenient and permissive. Also highlighted is the fact that neither methodological collectivism nor methodological individualism fully captures the dynamics at work in the process of film censorship in this case. As Matthew Pearce suggests in his discussion of Australian broadcasting policy, the process of media policy implementation can be better explained by the "duality of structure and agency" and how they work together, rather than simply focusing on one at the expense of the other. ${ }^{10}$

While there was significant continuity between the official views of new Minister of Internal Affairs Peter Tapsell and his predecessor Allan Highet, despite Tapsell's own personal conservatism, there is evidence of change in new Chief Censor Arthur Everard's approach, which was much more overtly based on appeals to empirical evidence than that of his predecessor Bernard Tunnicliffe. As is the case with many controversial films, much of the discussion surrounding I Spit on Your Grave is located in a discursive space outside the manifest content of the film itself.

I Spit on Your Grave is a "rape-revenge" film, or as Carol Clover suggests, "an almost crystalline example of the double-axis revenge plot so popular in modern horror: the revenge of the woman on her rapist, and the revenge of the city on the country", although Clover also notes that such a plot is not "exclusive to "low" genres" but is present in more mainstream films such as Sudden Impact (1983) and Deliverance (1972). ${ }^{11}$ Arguably, rape-revenge films exhibit a narrative structure that crosses over

\footnotetext{
${ }^{9}$ Egan, 3

${ }^{10}$ Matthew Pearce, "Perspectives of Australian Broadcasting Policy," Continuum 14, no 3 (2000): 367.

${ }^{11}$ Carol J. Clover, Men, Women, and Chain Saws: Gender in the Modern Horror Film (London: BFI, 1992), 115
} 
many genres rather than a genre themselves, although Claire Henry argues that "[t]he genre's diversity, and its frequent hybridity with other genres, does not discount that rape-revenge can be considered a genre in its own right." ${ }^{2}$ While Clover attempts to rehabilitate I Spit on Your Grave and argues that "for all its disturbing qualities [it] at least problematizes the issue of (male) sexual violence"13, initial critical reaction to the film was overwhelmingly negative. Marco Starr quotes several scathing reviews of the film, including Roger Ebert's well-known review which argues that the film has a "sick attitude towards women", and another that asks the rhetorical questions about the portrayal of sexual violence in the film, "How could actors play this scene? How could any director bring himself to shoot it"? ${ }^{14}$ Natalie S. Ingrassia notes that the film "is often regarded as an exploitation film aiming to bait its audience with unjustifiable and gratuitous violence". ${ }^{15}$ However, even as earlier as 1984, Martin Barker took the film seriously when discussing its status as a UK "video nasty", arguing that "it is not a gratuitous film", but in fact "a film about an idea", and rather than glorifying sexual violence, "[i]t wants us to hate the nature of the act of rape and that which it calls forth". ${ }^{16}$

I Spit on Your Grave was not submitted to the New Zealand censors at either the time of its original 1978 release as Day of the Woman or its 1980 rerelease under its more well-known (and arguably more sensationalist and exploitative) title. However, it did briefly come to the attention of Bernie Tunnicliffe in 1982 when a horror fan wrote to the censor's office requesting information on whether certain horror films, including I Spit on Your Grave as well as Tobe Hooper's The Texas Chain Saw Massacre, would be released in New Zealand. Tunnicliffe replied stating that I Spit on Your Grave had not been "approved for exhibition", but this in fact referred to a French film from 1959, J'irai cracher sur vos tombes (I Spit on Your Graves) that had been banned by the film

\footnotetext{
${ }^{12}$ Claire Henry, Revisionist Rape- Revenge: Redefining a Film Genre (New York: Palgrave Macmillan, 2014), 3.

${ }^{13}$ Clover, 115

${ }^{14}$ Marco Starr, "J. Hills is alive: a defence of I Spit on Your Grave." In The video nasties: Freedom and censorship in the media, edited by Martin Barker (London: Pluto Press, 1984), 48.

${ }^{15}$ Nathalie S. Ingrassia, "Rape, Revenge and Remake: Meir Zarchi's Day of the Woman and Steven Monroe's I Spit on Your Grave," FORUM: University of Edinburgh Postgraduate Journal of Culture and the Arts, 13 (2011) 1.

${ }^{16}$ Martin Barker, "Nasties': a problem of identification." In The video nasties: Freedom and censorship in the media, edited by Martin Barker (London: Pluto Press, 1984), 116, 113.
} 
censor in 1962. ${ }^{17}$ Meir Zarchi's film attracted censorship attention the following year when a video copy was seized by customs. Peter Ronald Jenkins attempted to import the film as well as Ruggero Deodato's Cannibal Holocaust (1980), but customs intercepted both tapes, and after pleading guilty to importing indecent publications, he was fined $\$ 75$ for each video. ${ }^{18}$ At the time of this successful prosecution, National Party MP Graeme Lee, who regularly made calls for stricter film and video censorship, complained that the fines were "paltry", and erroneously claimed that the two videos were in fact "snuff" films, and that "[p]eople are actually being employed under false pretences and then killed for the sake of other people's sadism". ${ }^{19}$ While the Society for the Promotion of Community Standards' newsletter of September 1984 claimed that I Spit on Your Grave had been declared indecent by Customs, ${ }^{20}$ Everard noted in response to this newsletter that Customs had no power to do that, and could only act on suspicion "that a film or video may be indecent" and then submit it to a court for a legal ruling. ${ }^{21}$ Since the importer had pleaded guilty, the film had not been subject to examination for censorship at this point. However, in 1984, another video copy was seized by customs, and this time it was forwarded to the Chief Censor to be examined. ${ }^{22}$ This VHS version was passed uncut with an R20 certificate on 29 June 1984, with the advisory note "contains graphic violence, content may disturb". The notes in the daybook, taken by Arthur Everard, indicate several potential cuts to the rape sequences in the first half of the film, with crosses in the margins and the note "reduce rape". However, after the whole film had been viewed, these cuts did not eventuate, suggesting that Everard was clearly taking the approach that contentious material needed to be assessed in the context of a film as a whole, not purely in isolation. ${ }^{23}$ There was also a note that the censor "reserve[d] right to give different

\footnotetext{
${ }^{17}$ AAAC W4156 Box 4 - Views Expressed on Films Generally 1981-1985.

${ }^{18}$ Evening Post, 30 August 1984, AAAC W5169 7536 Box 16 - Chief Censor and Departmental Responsibility - Video Legal Opinions 1978-1986.

19 The Dominion, 23 April 1983. While Ruggero Deodato had to defend charges in an Italian court that Cannibal Holocaust contained real deaths of actors, by the time the video was seized in New Zealand, Deodato had demonstrated that the actors were alive and all charges had been dropped. There had never been any serious suggestion that I Spit on Your Grave was a "snuff" film. 20 Newsletter No. 51, Society for the Promotion of Community Standard, September 1984. ${ }^{21}$ AAAC W4156 Box 5 - Pressure Groups - Society for the Promotion of Community Standards General 1979-1986.

22 Evening Post, 30 August 1984.

${ }^{23}$ ADNB 23133 W5730 Box 212 - Daybooks of Chief Censor of Films - 8/6/84 to 14/12/84.
} 
classification for 35mm". ${ }^{24}$ As tended to be the case during Everard's era as Chief Censor, the daybook notes for I Spit on Your Grave were purely descriptive of the film's content, displaying none of the disdain for low-budget exploitation films that sometimes made its way into the daybook notes while Bernard Tunnicliffe was Chief Censor (although many of these comments were by Deputy Chief Censor Diane Wren rather than Tunnicliffe himself). Other horror films that had achieved a level of notoriety, such as Tobe Hooper's The Texas Chain Saw Massacre ${ }^{25}$ and Lucio Fulci's Zombie Flesh Eaters ${ }^{26}$ received similar treatment in Everard's daybooks. Both were passed uncut, the latter albeit in a pre-cut print, and while there was a suggestion in the daybook that one of Zombie Flesh Eaters' most infamous moments, when a woman's eye is graphically pierced with a splinter of wood, might be cut, Everard noted that the "eye scene will be okay in context", and suggested that there was no need for a descriptive note to accompany the film's R16 classification as the "[t]itle removes need for [a] note". ${ }^{27}$

I Spit on Your Grave was examined by the censors again in a $35 \mathrm{~mm}$ version on 17 August 1984; the daybook notes this time taken by Deputy Chief Censor Sarah Ingram. These were similarly descriptive, although this time with no suggestions of any potential cuts, and the film was again given an R20 certificate, with the same note, "contains graphic violence, content may disturb". ${ }^{28}$ In the following year, two more video copies of I Spit on Your Grave, both noted as identical in content to the previous versions in the daybooks, were similarly passed uncut. ${ }^{29}$

The film was given a two week cinema run in Christchurch only. In a letter to Peter Tapsell, the Secretary of Internal Affairs indicated that the major cinema chains did not want to screen the film. ${ }^{30}$ This letter also noted that the complaints that had been received about the film did not "constitute widespread public concern as they are all

\footnotetext{
24 Ibid.

${ }^{25}$ ADNB 23133 W5730 Box 213 - Daybooks of Chief Censor of Films - 6/7/84 to 29/1/85.

${ }^{26}$ ADNB 23133 W5730 Box 212 - Daybooks of Chief Censor of Films - 8/6/84 to 14/12/84.

27 Ibid.

${ }^{28}$ ADNB 23133 W5730 Box 213 - Daybooks of Chief Censor of Films - 6/7/84 to 29/1/85.

${ }^{29}$ ADNB 23133 W5730 Box 218 - Daybooks of Chief Censor of Films - 19/6/85 to 12/12/85. The second of these video versions, on Betamax, was noted as "identical to VHS, $35 \mathrm{~mm}$ ", suggesting that all versions passed by the Chief Censor were the complete, uncut version. The video versions were several minutes shorter than the $35 \mathrm{~mm}$ version, but this is most likely due to PAL speedup.

${ }^{30}$ AAAC 7536 W5169 Box 15 - Campaign by Society for Promotion of Community Standards 19841987.
} 
based on overseas information rather than personal experience or knowledge of the film", and that an Internal Affairs staff member had contacted the manager of the cinema screening the film, "who reported that he received no comments from patrons who saw the film". ${ }^{31}$ The film was paired in a double-bill with William Lustig's low budget serial killer film Maniac (1980). ${ }^{32}$ This may have had some effect on the viewing context of the film, by presenting it as an "exploitation" film. As Marco Starr notes in his comments on Roger Ebert's disgust at the reaction of the audience with whom he watched I Spit on Your Grave, "[s]leazy titles and a grindhouse cinema atmosphere may help make the laughter flow so very freely" even if this does not seem an "appropriate" response to the film. ${ }^{33}$ Press coverage of the film's theatrical run was somewhat contradictory, perhaps reflective of how the film could polarise reactions. One article described the film as "having the dubious distinction of topping the British "video nasties" list", ${ }^{34}$ even though no such "rankings" existed, whereas another article headlined "Anti-rape film rejected" notes that most cinemas had chosen not to screen it, but that distributor Mark Galloway described it as "a very strong anti-rape statement" which "leaves no doubt rape is a horrendous crime". ${ }^{35}$

Everard's decision to pass the film uncut, even with a restrictive R20 certificate, resulted in a significant amount of controversy, and not just from the prominent campaigners for stricter censorship, the Society for the Promotion of Community Standards. In their newsletter of September 1984, the SPCS described Everard's decisions as "the most permissive on record", and listed several films that had been seized by customs and since passed by Everard, including I Spit on Your Grave, as well as films previously banned but now passed by Everard such as The Texas Chain Saw Massacre. The newsletter also drew attention to successful prosecutions of the film as a "video nasty" in the United Kingdom, and encouraged members to write to Peter Tapsell requesting that he "invoke section 34 of the Films Act" to have the film examined by the Board of Review. The newsletter further suggested that complainants could appeal to Tapsell's personal moral conservatism, stating that he "has voted

\footnotetext{
31 Ibid.

32 The Press, 31 January 1985.

${ }^{33}$ Starr, 54.

34 The Press, 24 January 1985.

${ }^{35}$ Evening Post, 29 November 1984.
} 
against abortion and is a caring man". ${ }^{36}$ A significant volume of correspondence addressed to Tapsell appears to have resulted directly from this newsletter, as the letters make reference to specific details from the newsletter. These correspondents invariably demonstrated no evidence that they had seen the film. Indeed, some focused simply on the title of the film: one asking "[h]ow would you like the idea of anyone spitting on the grave of your loved ones? ", while another wrote "[t]he very title of another film, "I spit on your grave," is a shame on our civilisation". ${ }^{37}$ Some letters also displayed a strong sense of religious conservatism, and conflated censorship with other "moral" issues such as sex education and abortion. As Barker and Petley note, pro-censorship views "do not exist in an ideological vacuum and generally tend to spring from deeply felt beliefs about how society should-and shouldn't—be organised and regulated", and are "part of a much wider ideological package which its proponents would have us accept, or would like to impose upon us". 38 The complainants also tended to display a very simplistic conception of the idea of media effects, arguing that violent films had a direct effect on violence in society - one correspondent stated that "I feel these films must affect those viewing them", while another argued that "I consider it highly likely that the increasing violence, rapes, etc can be directly traced to films such as these which put ideas in people's heads". ${ }^{39}$ As Attwell et al argue:

Narrow notions of 'media effects' are often the source of controversy about images, underpinning anxieties about representations that might inappropriately inspire us or deaden our proper responses....Such images make things too visible, bringing to light and 'on-scene' what should be kept off- and 'ob-scene'. 40

The group Women Against Pornography ${ }^{41}$ also wrote to Arthur Everard on 12 September 1984 on the subject of I Spit on Your Grave, as well as Tobe Hooper's The Texas Chain Saw Massacre, which had also been passed uncut by Everard. While this letter was much more measured in tone than many of the letters prompted by the

\footnotetext{
${ }^{36}$ Newsletter No. 51, Society for the Promotion of Community Standards, September 1984.

${ }^{37}$ AAAC 7536 W5084 Box 26 - Case Files - Campaign by S.P.C.S 1984.

38 Martin Barker and Julian Petley. "Introduction." In III Effects: The Media/Violence Debate, edited by Martin Barker and Julian Petley (London: Routledge, 1997), 4.

${ }^{39}$ AAAC 7536 W5084 Box 26 - Case Files - Campaign by S.P.C.S 1984.

40 Attwell et al, "Introduction." In Controversial Images: Media Representations on the Edge, edited by Feona Attwell et al (Basingstoke: Palgrave Macmillan, 2013), 3.

${ }^{41}$ While they shared the name of the better known American organisation, the two groups were not formally associated.
} 
SPCS's newsletter, and did make reference to an academic study which suggested that films such as I Spit on Your Grave led to "men becoming desensitized to violence against women", there is no direct reference to the content of either film, and it appears that the letter writers had most likely not seen them. ${ }^{42}$ They even went as far as creating a cartoon depiction of Everard, portraying him as a permissive censor "unlocking the door" to a wave of pornography, although this portrayal demonstrates a simplistic view of media effects by juxtaposing various film titles with headlines such as "Severe Beating" and "Girl Abducted" [Figure 1]. In fact, Everard had not passed any films containing explicit unsimulated sexual content at this point, and some of the films identified on the cartoon, such as Dracula Erotica (1980), were passed in versions already subject to significant cuts by the distributors. ${ }^{43}$

Everard responded to Women Against Pornography's letter with a detailed three-page letter of his own outlining his reasons for passing both films uncut for adult audiences. He referenced a large number of academic articles, particularly in the field of psychology, and suggested that there was a distinction to be made between changes in attitude and changes in behaviour resulting from viewing of films. In a carefully articulated view of the nature of media effects, he argued that the "while effects on attitudes have been widely demonstrated", these were often only short-term, and researchers "are less convinced that actual behaviour may be altered". 44 He further suggested that the study referred to by Women Against Pornography, having been conducted in "[c]ontrolled and artificial laboratory situations...may not validly extrapolate into real life situations." 45 He further noted that The Texas Chain Saw Massacre was "not a particularly violent film" and contained no sexual violence, and that while I Spit on Your Grave did portray rape, it was "not presented in a sensationalist manner", was "almost clinical in its approach to its subject matter, and that "the emotional effect is one of sympathy for the victim rather than empathy with the perpetrators". ${ }^{46}$ Everard also stressed the importance of viewing contentious

\footnotetext{
42 ADNB 23136 Box 7 - Pressure Groups - WAP Women Against Pornography 1984-1994.

43 In the case of Dracula Erotica, the daybook (ADNB 23133 W5730 Box 212 - Daybooks of Chief Censor of Films - 8/6/84 to 14/12/84) notes that all three censors viewed the film, not just Everard, and it was a pre-cut print from Australia. Even then, it was still given the highest possible restriction short of a ban, an R20 certificate.

${ }^{44}$ ADNB 23136 Box 7 - Pressure Groups - WAP Women Against Pornography 1984-1994.

45 Ibid.

46 Ibid.
} 
material such as sexual violence in the context of the film as a whole, arguing that "the treatment of the material is just as important as its content, the theme cannot be considered in isolation from the way it is presented". ${ }^{47}$

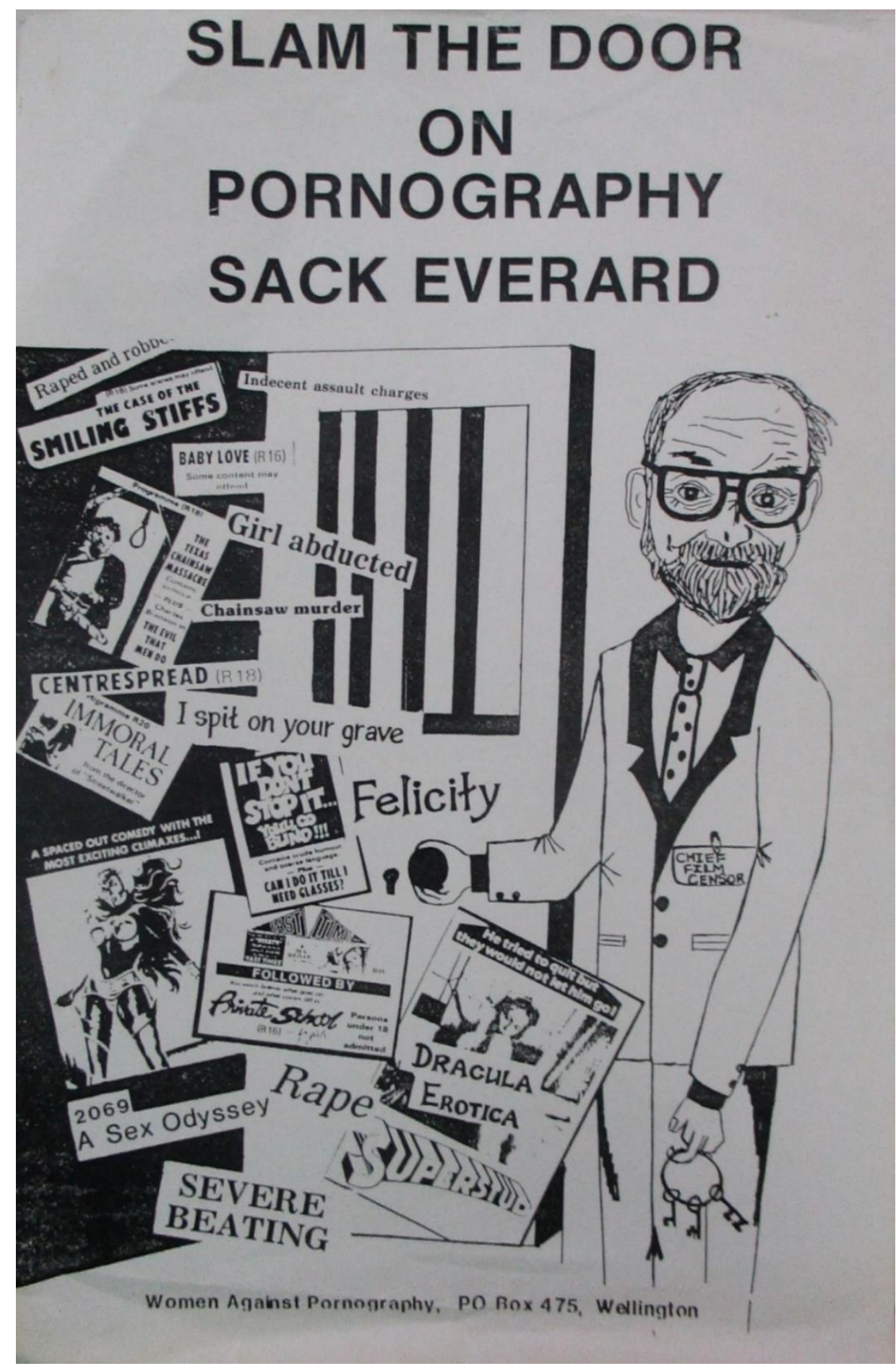

Figure 1: Women Against Pornography cartoon of Arthur Everard (from ADNB 23136 Box 7 Pressure Groups - WAP Women Against Pornography 1984-1994).

47 lbid. 
While most correspondence to the Chief Censor and Minister of Internal Affairs was from people who had not in fact seen the film, one of the Christchurch cinema screenings prompted a letter to Chief Censor Arthur Everard from the organisation Men Against Rape. However, the emphasis in this letter was less on the content of the film itself, but more on the reaction of other members of the cinema audience. The letter's author claimed that "[t]he response of men in the audience to the film...was one of laughter and jokes about a woman being raped". ${ }^{48}$ In response, Everard went into even more detail on the nature of his decision to pass the film than his letter to Women Against Pornography, with a six page reply quoting extensively from academic articles on the subject of horror films in general, and I Spit on Your Grave in particular. In response to claims by Men Against Rape that exposure to violent media leads to desensitisation to real violence, Everard argued that based on his knowledge of research on the subject, this was a "vastly over-generalised simplification of a complex situation". ${ }^{49} \mathrm{He}$ noted that when the film was originally classified, it was shown to "several people (male and female)" who had a "unanimous reaction" of "pity and sympathy with the victim" rather than identifying with the rapists, although there does not appear to be a detailed record of this consultation in the files held by Archives New Zealand. ${ }^{50}$ Everard concluded by stating that he was "glad that [Men Against Rape] were appalled" as this was an appropriate reaction to the film's content, and that I Spit on Your Grave "does not condone rape... it shows it for the sad affair it really is; for the victim, for the perpetrators, for society". ${ }^{51}$ While in the United Kingdom, those such as Martin Barker who had spoken out in defence of the "video nasties" had found that their voices carried little weight, Everard directly referenced Barker's writings on I Spit on Your Grave in defence of his decision to pass the film, noting that Barker "maintains that the film is actually an anti-rape one", and quoting at length from an article by Barker in New Society in which Barker states that he "cannot doubt the film's serious intentions". 52

\footnotetext{
${ }^{48}$ AAAC 7536 W5169 Box 15 - Campaign by Society for Promotion of Community Standards 19841987.

$49 \mathrm{lbid}$.

$50 \mathrm{lbid}$.

51 lbid.

52 lbid.
} 
Throughout this time, Peter Tapsell remained supportive of Arthur Everard, while still maintaining his own personal conservatism, and clearly making a distinction between his personal and professional views on the issue of film and censorship, something which his predecessor Allan Highet had also done. Early in his tenure as Minister of Internal Affairs, Tapsell made this distinction quite explicit in a letter to the Dominion President of the Women's Division of Federated Farmers, who had written to Tapsell "deeply concerned by the increasing violence in our society, and the growing exaggeration of it in films, ostensibly for entertainment and particularly in videos for home viewing". 53 Tapsell replied:

It may comfort you to know that my personal view is more in line with that of your Division, but because discussions have not as yet been completed, I cannot say that this is the view of the Government. ${ }^{54}$

In other correspondence, Tapsell noted that the role of Chief Censor was "to reflect the standards of the community at large, not those of a minority", and mentioned in several of his letters the 1982 Heylen poll which had indicated that the public did not want stricter film censorship. ${ }^{55} \mathrm{He}$ also argued that "[t]he imposition of a minority view on film censorship standards upon the majority of the population is quite repugnant to my Government" 56 , and in multiple letters stated that he did not see a direct link between screen violence and violence in society, stating in one case that "[i]t has not yet been proven that there is a causal link between the visual media and violence in society and there is much disagreement as to the effects of material in films and video tapes on viewers", although unlike Everard he did not further elaborate on this position or make reference to specific studies. ${ }^{57}$ However, even after he had accepted and conveyed the government's official position on the issue of censorship, he still placed himself in the minority to which he referred, in one letter making his personal moral conservatism quite explicit:

The general standard of morality has unfortunately deteriorated to the stage where we are able to accept immorality among ourselves, but be critical of it in others. Many of those who express

\footnotetext{
${ }^{53}$ AAAC 7536 W5169 Box 5 - Videos for Private Viewing - Ministerial Correspondence 1985-1989. 54 Ibid.

${ }^{55}$ AAAC 7536 W5084 Box 26 - Case Files - Campaign by S.P.C.S 1984.

56 Ibid.

${ }^{57}$ AAAC 7536 W5169 Box 15 - Campaign by Society for Promotion of Community Standards 19841987.
} 
horror at violence in rape, for example, do not consider the destruction of a 12 weeks old human to be in any way violent. 58

Nevertheless, in this same letter, he went on to say that he considered Arthur Everard to be carrying out his job in a "sensitive and responsible way", albeit that he was simply "bound to reflect what the majority of people rather sadly want". ${ }^{59}$ Arthur Everard's recollections in my interview with him support the view that Tapsell took a measured view on the issue of censorship despite his personal feelings. He noted that Tapsell visited the Chief Censor's office after becoming Minister of Internal Affairs and "came with an open mind", asked "pertinent questions", Everard being "quite impressed as he obviously had not made up his mind in any way". 60

I Spit on Your Grave was never submitted on video to the Video Recordings Authority after it was established in 1987, and did not come before the New Zealand censors again until 2011, when a blu-ray version was submitted to the Office of Film and Literature Classification. It was given an R18 classification, uncut, although the written decision suggests that this was perhaps slightly reluctant:

However, the original version, uncut, was released to adult viewers by the Chief Censor of Films in 1984. This version has been marketed on DVD for several years. The Classification Office has had no complaints about the publication from members of the public in this time and there is no evidence of harm arising from its availability to adults. In light of these considerations, a ban at this stage on the original version would be unreasonable. ${ }^{61}$

The reference to this being the "original version" is due to a remake being released in 2010, which was banned in New Zealand in 2011 as it was considered that it "invite[s] viewers to become complicit in events and to take vicarious pleasure in the men's misogyny and the woman's abject fear and debasement". 62

In 1985, another "video nasty", Abel Ferrara's The Driller Killer, was also passed uncut by Everard, this time with a slightly less restrictive R18 certificate rather than I Spit on Your Grave's R20 classification. The film was initially examined in 35mm form on 16 April 1985 by one of the Deputy Censors, Sarah Ingram, who tentatively noted in the

\footnotetext{
58 lbid.

59 lbid.

60 Interview with Arthur Everard.

61 Office of Film and Literature Classification online database, http://www.classificationoffice.govt.nz/DDA/Pages/Screens/DDA/WelcomePage.aspx. 62 Ibid.
} 
daybook "R18 N/C(?)" (R18 no cuts), with an additional note "hold for Arthur [Everard]", since Everard as Chief Censor had the final say and was ultimately responsible for any censorship decisions made by his office. ${ }^{63}$ After Everard had also viewed the film, the uncut R18 rating was formally registered on 22 April, with the note "graphic violence may disturb". A week later, the same uncut version was passed on Betamax and VHS video, with a slight difference in the running time of the Betamax version attributed to "telecine conversion". 64

Unlike I Spit on Your Grave, The Driller Killer does not contain any sexual violence, and much of its notoriety as a "video nasty" in the UK derived from its lurid advertising. Kate Egan notes that many British "video nasty" covers "focus on a moment of violent spectacle", including that of The Driller Killer which displays a graphic still from the film of a drill entering a man's head and the tagline "The blood runs in rivers...and the drill keeps tearing through flesh and bone". ${ }^{65}$ In contrast, the New Zealand video cover displayed an illustration of main character Reno (played by the director Abel Ferrara under the pseudonym Jimmy Laine) holding a drill but not directly engaged in a violent act. [Figure 2] The SPCS, who led the charge against the film, described it in their newsletter in the following manner:

It depicts twelve brutal killings with a portapack electric drill. Unsuspecting persons are drilled to death through the forehead, stomach, chest, back, in the most explicit detail. ${ }^{66}$

Aside from the fact that not all of the killings are shown in "explicit detail" (several are shown only briefly and without any visible blood or graphic close-ups), this is an extremely reductionist description of the film, as the violence only makes up a relatively small fraction of the running time. Indeed, no murders are committed until over 35 minutes into the film, and it would be equally accurate (but equally misleading) to state that the film "depicts a punk band rehearsing", as much of the running time shows this as well. As Brad Stevens argues in his book Abel Ferrara: The Moral Vision, to focus solely on the murders misrepresents the way the film treats its central character:

The way we judge Reno is determined by how he behaves at any specific moment: we are encouraged to take him at face value whenever he demonstrates spontaneous affection, but

\footnotetext{
${ }^{63}$ ADNB 23133 W5730 Box 214 - Daybooks of Chief Censor of Films - 19/10/84 to 16/5/85.

$64 \mathrm{lbid}$

${ }^{65}$ Egan, 52-53.

66 SPCS Newsletter Number 55, November 1985.
} 
compelled to draw conclusions of a quite different kind during the murder sprees. Ferrara's condemnation of the killings while they are being committed is absolute, but our evaluation of the character and his actions can only exist as those actions occur ${ }^{67}$
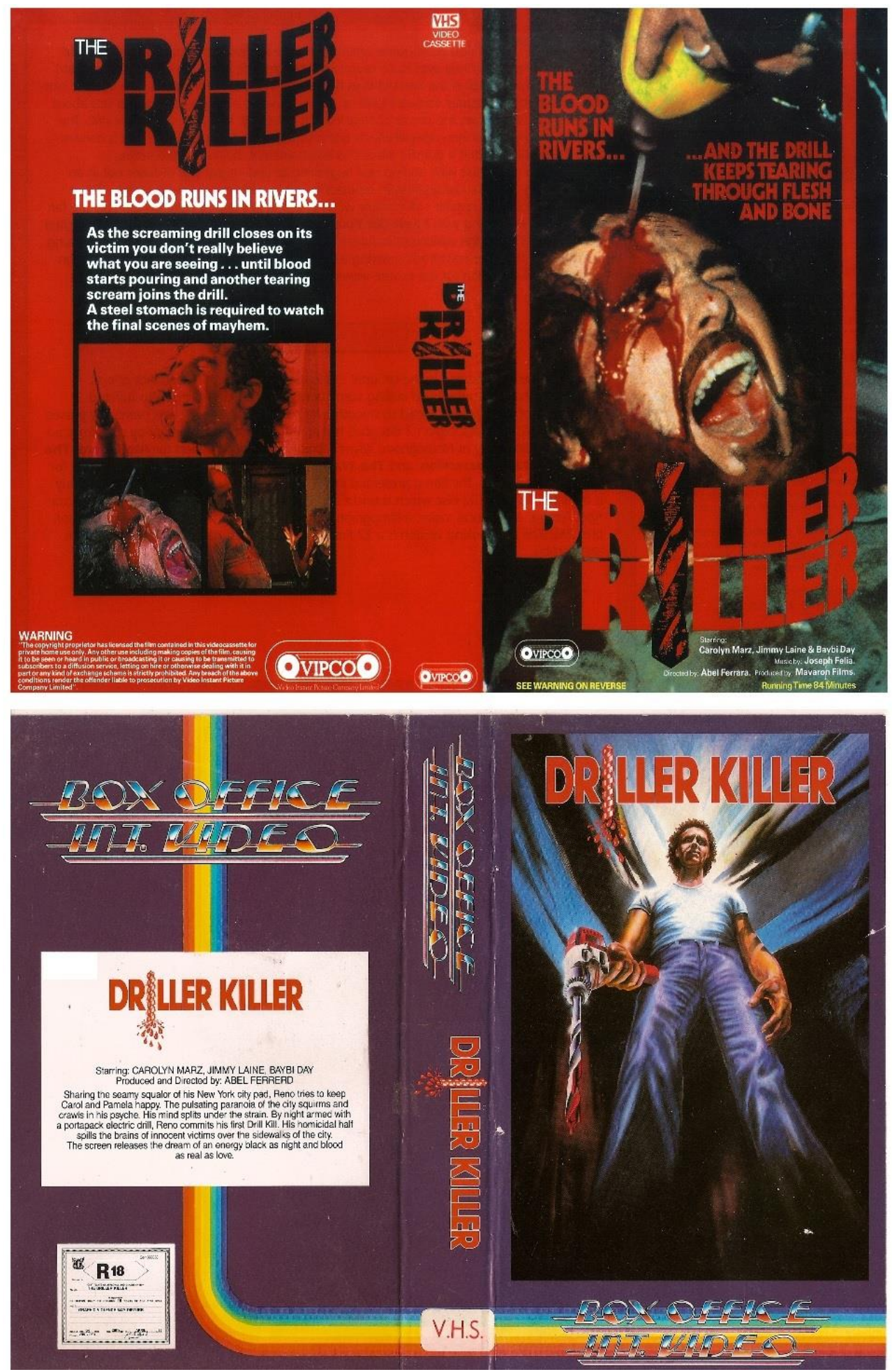

Figure 2: Comparison of UK and New Zealand video covers of The Driller Killer.

${ }^{67}$ Brad Stevens, Abel Ferrara: The Moral Vision (Godalming: FAB Press, 2004), 47-48. 
Controversy surrounding the film was more muted than that over I Spit On Your Grave, and largely emanated from the Society for the Promotion of Community Standards. As well as arranging a screening of the film to MPs to attempt to draw attention to socalled "video nasties", Patricia Bartlett wrote a letter to Minister of Internal Affairs Peter Tapsell headed "VIDEO NASTY - “DRILLER KILLER” VHS”. She mentioned UK court cases where the film had been subject to successful prosecutions under the Obscene Publications Act, and argued that "in the Society's [for the Promotion of Community Standards] view depiction of horror in this film has gone too far as evident by the English courts' action", and requested that Tapsell intervene to stop exhibition of the film under Section 34 of the Films Act 1983 and refer the film to the Films Censorship Board of Review. ${ }^{68}$

In response to Bartlett's complaints, Arthur Everard prepared a detailed rebuttal of her allegations for Peter Tapsell, noting that reports about the film from those such as Bartlett who "do not appear to have seen the film about which they are so critical" have a "sensationalist tone" that doesn't reflect the content of the actual film. Instead, Everard suggests that it is not "a continuous bloodbath of explicit, gratuitous violence from start to finish", and that there were in fact "only several scenes of bloodshed in it". ${ }^{69}$ Everard also addressed Bartlett's reference to the UK report Video Violence and Children, which was a key part of the British "video nasties" scare, noting that it "has been long discredited", and that an article based on this report from the New Zealand Women's Weekly, which Bartlett had also attached, was "[j]ournalistic sensationalism" which "deserves the same ridicule as its parent fiction". ${ }^{70}$ In the UK, this report had been taken much more seriously, Martin Barker noting that it "provided the press with the little bit of proof needed to put the finishing touches to the campaign" against video nasties ${ }^{71}$, even though Julian Petley notes that same press was "normally highly dismissive of academic research, which it likes to characterise as the work of 'boffins' or inhabitants of the ivory tower". ${ }^{72}$

\footnotetext{
${ }^{68}$ AAAC 7536 W5084 Box 44 - Correspondence with the S.P.C.S. 1984-1985.

$69 \mathrm{lbid}$

70 lbid.

${ }^{71}$ Barker, "Nasty politics or video nasties?", 5.

72 Julian Petley, '“Are We Insane?' The 'Video Nasty' Moral Panic." In Moral Panics in the

Contemporary World, edited by Chas Critcher et al (New York: Bloomsbury, 2016), 83.
} 
Tapsell also received a letter from former film censor Ainslie Witaszek, now working for the Secretary of Internal Affairs. This letter advised Tapsell on the legal position regarding The Driller Killer, and his role as Minister of Internal Affairs in the censorship process, rather than discussing the content of the film itself. Witaszek noted that Tapsell had the power to intervene after a film had been passed by the Chief Censor if it had been publicly exhibited and if such exhibition could be considered "injurious to the public good" as a result of "widespread public concern" or a negative impact on "the general public or any class of the general public". ${ }^{73}$ Witaszek pointed out that the film had not been shown publicly, and was at the time "not expected to be", and that "looking ahead" even if it was later exhibited, "it is debatable whether Ms Bartlett's pressure group by itself constitutes "widespread public concern"'. ${ }^{74}$ Like Everard, Witaszek also made reference to the Society for the Promotion of Community Standards' reliance on the British report Video Violence and Children, arguing that Bartlett's "case is weakened by its reliance on discredited and hearsay material...instead of personal viewing and analysis of the film she complains about". ${ }^{75}$

As evidenced by his responses to Patricia Bartlett, Tapsell appears to have accepted Everard's and Witaszek's judgement on this matter. He explained to Bartlett that Video Violence and Children had been "widely discredited", attaching various articles from publications such as The Times and The Economist as evidence of this, and suggesting that Bartlett was "endangering [her] credibility and that of [her] Society" by continuing to "unconditionally rely on it". ${ }^{76}$ Tapsell also pointed out that he could not take any action unless The Driller Killer was actually publicly exhibited. ${ }^{77}$ After an exchange of letters, Tapsell became increasingly frustrated with Bartlett's approach, stating that he did not "intend to enter into a points-scoring contest on DRILLER KILLER", and that Bartlett's appeals to UK prosecutions of the film as a "video nasty" were not relevant as "[a] comparison is valid if it compares like with like", and that Bartlett was not doing so. ${ }^{78} \mathrm{In}$ response to another correspondent protesting Everard's decision to pass the film, Tapsell explained this position further, arguing that "[a]nyone

\footnotetext{
${ }^{73}$ AAAC 7536 W5084 Box 44 - Correspondence with the S.P.C.S. 1984-1985.

$74 \mathrm{lbid}$.

$75 \mathrm{lbid}$

76 lbid.

77 lbid.

$78 \mathrm{lbid}$.
} 
who has seen a film they complain about has a better basis for their criticism than someone who has not seen it", and pointing out that the correspondent had not seen the film but had formed his opinions based on an article in the Otago Daily Times. ${ }^{79}$ This article erroneously claimed that the "video nastie" [sic] involved "the brutal murder of twelve women by a mad man wielding an electric drill". ${ }^{80}$ Tapsell also made explicit his continued support for Everard, whom he noted was not required to "set a moral tone or personal values", but instead analyse the content of a film "with the maximum of objectivity" in relation to the Films Act which governed censorship. ${ }^{81}$

Bartlett's complaints about the film had the effect of generating publicity. An article in the Sunday News noted that increased public awareness of the film had turned it into a "box-office money spinner" for Wellington's Paramount Theatre, whose manager suggested that it would otherwise "have warranted only a Sunday screening or perhaps not at all". ${ }^{82}$ Similarly, an Auckland video store owner suggested that Bartlett's complaints were "the best thing that ever happened to Driller Killer", and that the previously neglected video release was now rented several times a week. ${ }^{83}$

The public screenings of the film in Wellington, apparently partly the result of the publicity created around the film by the Society for the Promotion of Community Standards, resulted in further complaints about the film. The Society's newsletter requested that members write to Tapsell asking for him to refer the film to the Board of Review, and that "[s]ilence gives your consent". ${ }^{84}$ Tapsell's letters in response to these new complaints about the film at this time all note that he considers that there had been "no evidence to show that the public exhibition of The Driller Killer has caused widespread public concern or had an apparent effect on any class of the general public", and thus he was unable to take any action against it under the Films Act. ${ }^{85}$ The Driller Killer was never submitted to the Video Recordings Authority for

\footnotetext{
${ }^{79}$ AAAC 7536 W5169 Box 15 - Campaign by Society for Promotion of Community Standards 19841987

80 Otago Daily Times, 27 July 1985.

${ }^{81}$ AAAC 7536 W5169 Box 15 - Campaign by Society for Promotion of Community Standards 19841987.

82 Sunday News, 20 October 1985.

${ }^{83}$ Auckland Star, 23 October 1985.

${ }^{84}$ Newsletter No. 55, Society for the Promotion of Community Standards, November 1985.

${ }^{85}$ AAAC W4156 Box 5 - Pressure Groups - Society for the Promotion of Community Standards General 1979-1986.
} 
examination, and did not reappear for classification in New Zealand until 2004, when an uncut DVD version was again passed with an R18 certificate.

\section{Spit on Your Grave and The Driller Killer - analysis}

As was the case with so many films surrounded by controversy, the manifest content of I Spit on Your Grave was not as significant a factor in the controversy as it might appear on the surface, and much of the controversy surrounding the film came from those who had not seen it and were ill-informed about its content. Even in the case of the letter of complaint by Men Against Rape, where the writers had seen the film, there was little discussion of the content of the film itself. In a manner similar to Roger Ebert's review of the film, which focused on the audience with which he saw it and stated that if some of the audience members "seriously believed the things they were saying, they were vicarious sex criminals", Men Against Rape focused on the audience's response to the film. As Barker and Petley note, responding to complaints about films being “"gratuitous', 'excessive' and 'harmful'” are difficult to respond to, as "[e]ven if you have seen the material in question, how exactly do you prove that it isn't 'gratuitous'?". ${ }^{86}$ Everard's approach during his tenure, which he clearly established in his defence of his decision to pass I Spit on Your Grave uncut, was to discuss in great detail not just the content of a film, but how it portrays that content - in the case of I Spit on Your Grave, the mere portrayal of rape was not grounds for a ban, as it was necessary to consider how it was portrayed.

The discourse around the perceived impact of the film demonstrated a clear divide between those who opposed the film being passed, and those who supported the Chief Censor's decision, particularly in their respective understandings of the idea of media effects. Those complaining of Everard's decision to pass the film took a very simplistic view of media effects, arguing that the film had a direct, identifiable effect on behaviour and attitudes. The Chief Censor's view was much more nuanced, recognising prevailing views in academic research on the subject rather than the more outdated views expressed by those opposed to the film. Minister of Internal Affairs

${ }^{86}$ Barker and Petley, 7. 
Peter Tapsell also noted the lack of direct evidence of a causal link between visual media and real life crime and violence, although the correspondence makes it clear that this was the "official" government view (which was a view consistent with that expressed by the previous National government) and not his personal view - thus demonstrating a significant degree of consistency of approach transcending any individual, as "structures persist while individual members of those structures come and go", and that "structures (institutions) create more regularity of human behaviour than would otherwise exist". ${ }^{87}$

While I Spit on Your Grave was notorious as a "video nasty" in the UK, its availability on video was not a major factor in the discourse surrounding the film, which centred largely around the views about the film's alleged content (however inaccurate these might be) rather than the specific context within which it was viewed. Indeed, while the SPCS newsletter did point out Obscene Publications Act prosecutions of the film on video in the UK, the term "video nasty" itself was not used by the SPCS at this stage. Additionally, a number of those who were prompted to complain about the film by this newsletter demonstrated confusion over the distinction between cinema and home video, one correspondent being "appalled at some of the titles of the videos that have been passed recently for viewing in cinemas", and another describing I Spit on Your Grave as a "videofilm". ${ }^{8}$

As a film that polarises audiences, views on the artistic merit of I Spit on Your Grave have varied widely ever since its original release. It is notable that Chief Censor Arthur Everard, while not stating that I Spit on Your Grave was "important", did consider it to be a film of some quality and not merely shallow exploitation, reflecting similar contemporary views expressed by Martin Barker and later reappraisals of the film by academics such as Carol Clover. However, Everard was also equally willing to pass other controversial films even if he did not find artistic merit in them, passing the previously banned The Texas Chain Saw Massacre uncut even though he personally considered it "not worth the publicity it has generated", noting that "there is more violence suggested in the advertising and the title than there is actually shown in the

${ }^{87}$ B. Guy Peters, "Institutional theory: problems and prospects." In Debating institutionalism, edited by Jon Pierre, B. Guy Peters and Gerry Stoker (Manchester: Manchester University Press, 2008), 6. ${ }^{88}$ AAAC 7536 W5084 Box 26 - Case Files - Campaign by S.P.C.S 1984. 
film" ${ }^{89}$ In another letter, he made this point even more explicit, stating that it "may be "visual garbage" as [the correspondent] suggest[s] but this is not sufficient justification for rejecting it". 90

As with many controversial films, much of the disagreement about I Spit on Your Grave derived not merely from the portrayal of contentious material such as sexual violence, but differing perceptions about the way it was portrayed. As Carol Clover argues in her discussion of I Spit on Your Grave, "pinning down politics can be a tricky business even in the most seemingly transparent of cases, and that the politics of horror in general and this film in particular are less than self-evident". ${ }^{91}$ However, in making a classification decision, a censor has to "pin down" the meaning of a film to some extent, and in the case of I Spit on Your Grave, Arthur Everard made it quite clear in his correspondence how he interpreted the film's message. Everard felt that the film was intended to make audiences sympathise with the victim and not the perpetrators, and that being "appalled" was in fact the appropriate response.

Much more so than his predecessor Bernard Tunnicliffe, Arthur Everard would make appeals to third party authorities in the form of research and academic articles as a means of explaining and justifying his censorship decisions, and this was very much evident in the case of I Spit on Your Grave. His defence of the film in multiple letters was extremely detailed, and while many of the views he expressed, such as those on media effects, were very similar to Tunnicliffe's, they were articulated with much greater depth and precision than Tunnicliffe's more brief and generalised defences of his decisions. In reflecting back on his decision to also pass sexually explicit videos around the same time, Everard explained his attitude to academic research as a kind of obligation as a censor; that if evidence suggested that sexually explicit material involving consenting adults was not harmful, "how could we ignore it?"92 While Everard did show I Spit on Your Grave film to "several people" at the time of submission to the Chief Censor, his justification of this decision, and others, weighed much more heavily on academic research than direct consultation, in contrast to Bernard Tunnicliffe, who tended to rely only on such "ad hoc" consultations. Everard's successor, Jane

\footnotetext{
${ }^{89}$ AAAC W4156 Box 4 - Ministerial Censorship Correspondence 1917-1986.

90 Ibid.

91 Clover, 116.

92 Interview with Arthur Everard.
} 
Wrightson, would rely more heavily on formal consultations with members of the public as a way of rationalising censorship decisions.

There was also some limited investigation into the reception of the film by cinema audiences during its brief run in Christchurch, although this seems to have been a "post hoc" justification for the Chief Censor's decision to pass the film, a process which James G. March calls "posterior preferences", or the process of "find[ing] meaning and merit in our actions after they are taken and the consequences are observed and interpreted". ${ }^{93}$ Similar exercises had been undertaken before, such as in the case of Tinto Brass's Caligula, passed in a pre-cut version by Bernard Tunnicliffe in 1983. As part of this "general monitoring of public reaction" to that film, two Internal Affairs officers attended a screening of Caligula in Wellington on 29 November 1983, with a total of 288 people in the audience. ${ }^{94}$ They noted that there "was very little audience reaction to the film", and that at the end of the film "the audience emerged... without any discernible expressions of disgust or enjoyment". ${ }^{95}$ The two officers had also talked to the cinema's manager and other cinema employees before the screening "on impressions they had gained from the audience during the previous three weeks". ${ }^{96}$ The Secretary for Internal Affairs wrote to Highet explaining that "[o]n this evidence there is no basis for Ministerial intervention" to refer Caligula to the Board of Review as it was not evident that "continued exhibition is likely to be injurious to the public good". 97

The controversy the following year over The Driller Killer was somewhat similar to that surrounding I Spit on Your Grave, suggesting that the concern of those advocating for stricter censorship was more about an imagined "type" of film than any specific film. Again, complaints about the film came largely from those who hadn't seen the film, or stressed only the violent elements of the film without taking into account their wider context. Chief Censor Arthur Everard was able to look past the film's reputation and title, recognising that it did not in fact contain a large amount of graphic violence. Like I Spit on Your Grave, the level of discursive legitimacy given to the various views on

\footnotetext{
93 James March, "Bounded Rationality, Ambiguity, and the Engineering of Choice." In Rational Choice, edited by Jon Elster (Oxford: Basil Blackwell, 1986), 160.

${ }^{94}$ AAAC 7536 W5169 Box 15 - Chief Censor and his Decisions - Caligula 1983-1984.

$95 \mathrm{lbid}$.

96 lbid.

97 Ibid.
} 
the film was directly related to the level of perceived knowledge of the film's actual content. Everard's defence of his decision to pass the film uncut demonstrated less appeal to evidence from research on film violence and media effects than in the case of I Spit on Your Grave, although he did make reference to the SPCS's attempt to use the Video Violence and Children report to sway opinion against the film, arguing that it lacked credibility and provided no real support for their position. However, one significant difference in the case of The Driller Killer's New Zealand censorship history from that of I Spit on Your Grave was that the issue of The Drillers Killer's status as a home video release was part of the discourse about the film. While Everard's predecessor, Bernard Tunnicliffe, had not had to deal head-on with the issue of home video censorship, during Everard's tenure as Chief Censor it became a significant issue and resulted in much discussion and comment by the public and politicians.

\section{The problem of home video censorship}

While the early concern of moral campaigners such as the Society for the Promotion of Community Standards had mostly been about sexual content in home video rather than violence, the controversy surrounding The Driller Killer, in which the discourse about the film included reference to its status as a "video nasty" in the United Kingdom, demonstrated that some of this concern was beginning to shift towards violence in videos. Since the increased availability of home video in New Zealand after the removal of import licencing in 1980, there had been a variety of attempts at dealing with the perceived problem of home video censorship. The video industry had been in discussions with the government over how to deal with video classification, and on 12 June 1984 two representatives of the Video Retailers Association met with Department of Internal Affairs officials, with "[t]he major outcome of the meeting" being that the Video Retailers Association would "look into setting up a system of accurate consumer labelling" for videos. ${ }^{98}$ The minutes of the meeting also noted that a strong legislative approach was not desired by either party:

\footnotetext{
98 AAAC 7536 W5084 Box 44 - Chief Censor and Departmental Responsibility - Video Interdepartmental Committee 1982-1985.
} 
It was agreed that standards of censorship for public viewing need not apply to private viewing and Mr Fry pointed out it is the Government's view that Internal Affairs need not become involved in the latter. However, it was also pointed out that there is some public pressure for the Government to act in this area and it would therefore be wise for the industry to act responsibly in the area of consumer labelling etc to avoid legislation. ${ }^{99}$

Around this time, The Dominion had reported that distributors of videotapes were "adopting their own viewing-age guidelines as they wait for the New Zealand Video Association to make up its mind on the subject". ${ }^{100}$

The Secretary for Internal Affairs provided a briefing for the new Minister of Internal Affairs in the newly elected Labour government, Peter Tapsell, explaining the situation surrounding videotapes at the time. This briefing explained videos "considered to be offensive or indecent" came under the Indecent Publications Act and were dealt with by Customs and the courts, and that the previous government had favoured a voluntary classification system for videos, which the Department considered was "still preferable" to more heavily restrictive approaches. ${ }^{101}$

In 1984, an Interdepartmental Committee on video censorship was set up, including representatives from the Ministry of Internal Affairs, Ministry of Justice, and the Department of Customs. There was considerable tension between Customs and Arthur Everard at this time, with B.D. Fry of Internal Affairs writing in a file note dated 2 October 1984 that a representative from Customs had stated that Everard "is the most permissive [Chief Censor] that has been appointed", that they had "no faith at all in his judgement". 102 In fact, it appears that Customs had been concerned about the Chief Censor's decisions since before Everard's appointment, as Fry notes that the Customs representative stated that "the Chief Censor has been out of touch with the community for the last two or three years", which would encompass Bernard Tunnicliffe's time in the role, and Fry noted that "[t]his argument appears to have had its origins with the film "Caligula"', which Tunnicliffe had passed in a cut form but of which Customs had stated that "if [it] was a book they would have banned it". ${ }^{103}$

\footnotetext{
99 lbid.

100 The Dominion, 19 May 1984.

101 AAAC 7536 W5084 Box 44 - Chief Censor and Departmental Responsibility - Video Interdepartmental Committee 1982-1985.

102 AAAC 7536 W5169 Box 16 - Chief Censor and Departmental Responsibility - Video Legal Opinions 1978-1986.

103 Ibid.
} 
Everard himself wrote to the Secretary of Internal Affairs on 26 February 1985, evidently frustrated with the way Customs had been dealing with the pornographic videotape Café Flesh, which had been passed by the Chief Censor, and argued that:

Perhaps Customs has re-defined the word "co-operation" to exclude this word's usual meanings of mutual fair dealing, courtesy and respect so that it means now only whatever accords with Customs' wishes, requirements and demands? 104

However, the following month this issue appears to have been resolved to some extent, with B.D. Fry noting in a letter to Ainslie Witaszek, now working at Internal Affairs, that Customs would accept decisions on videotapes by the Chief Censor:

Murdoch Taylor stated at the last video meeting that Customs would now accept that the Chief Censor's decisions approving videotapes for public viewing implied logically that it would be suitable for viewing privately, and that Customs would adopt this policy in future. ${ }^{105}$

Among the members of the Interdepartmental Committee, there was also significant disagreement before a final report of recommendations was issued. Ainslie Witaszek noted that the meeting of 19 December 1984 "could best be described as adversarial", although she noted that the meeting of 31 January 1985 was "amazingly amicable"106, and a report was eventually issued on 23 May 1985. At this time, there was "no uniform, systematic information... provided to assist videotape users to decide whether videotapes they are thinking of hiring or buying are suitable for children or for other audiences". There were in fact two systems in place, Australian video classifications and the New Zealand Chief Censor's classifications, the latter "which in reduced form appears on the actual videotape as well as externally on the cartridge". ${ }^{107}$ The report acknowledged that both the Society for the Promotion of Community Standards and Women Against Pornography had expressed concerns about home video, but did not consider that their views reflected wider public opinion, arguing that "[b]oth SPCS and WAP would oppose material they believe is indecent being available in the private

\footnotetext{
104 Ibid.

$105 \mathrm{Ibid}$. Interestingly, this "logical" position would be put to the test after the passage of the Video Recordings Act in 1987, as the Video Recordings Authority was to ban on video some films that had been passed for public viewing by the Chief Censor.

${ }^{106}$ AAAC 7536 W5084 Box 44 - Chief Censor and Departmental Responsibility - Video Interdepartmental Committee 1982-1985.

107 AAAC 7536 W5169 Box 17 - Chief Censor and Departmental Responsibility - Video Interdepartmental Committee 1983-1987. The video releases of both I Spit on Your Grave and The Driller Killer bore the Chief Censor's classifications, R20 and R18 respectively.
} 
home; and both hold views which do not accord with the majority of respondents to the Heylen Poll". 108 The Committee recommended that "Ministers consider whether there is presently a need to establish a statutory tribunal for the purpose of determining whether or not any videotape submitted to it is indecent", and that in the meantime, the Government "notes the moves by the video industry to introduce a voluntary public information system amongst its members". ${ }^{109}$ The report also acknowledged a Private Member's Bill on the subject of video classification introduced by National Party MP Graeme Lee on 15 March 1985, although it was considered that this did not "provide a viable solution". ${ }^{110}$ However, even Lee's language did not stress heavy restriction and censorship, as he suggested that he did not support "a full censorship body" as in the UK, but rather that his Bill would provide "a consumer guide for people who purchase or hire videotapes from retail stores". ${ }^{111}$ The media discourse around this Bill, such as an article in the Evening Post headlined "Video nasties heading for early Govt action"112, suggests that the idea of "video nasties" had worked its way into the discussion around the issue of video censorship in New Zealand. As the next section will demonstrate, this was in a significant part due to the efforts of the SPCS to directly link the New Zealand debate with that which had been occurring in the UK for several years.

\section{The "video nasties" compilation tape - historical narrative}

By 1985, home video was well established in New Zealand, but was not the subject of any dedicated censorship legislation. In an attempt to persuade New Zealand's parliament to introduce restrictive video censorship, the Society for the Promotion of Community Standards brought Chief Superintendent Peter Kruger, who had until recently headed Scotland Yard's Obscene Publications Branch, to speak on the subject of video censorship. Kruger had been involved with the prosecution of "video nasties" under the UK's Obscene Publications Act. In the resume which he provided

\footnotetext{
108 Ibid.

109 lbid.

110 Ibid.

111 New Zealand Parliamentary Debates, 15 March 1985, 3688-3689.

112 Evening Post, 13 November 1985.
} 
to the SPCS's Patricia Bartlett, he described his role as one akin to combating a disease, stating that he was "very much involved in the outbreak and spread of 'video nasties"' and "[h]ad meetings at Home Office on proposed legislation to combat video nasties". ${ }^{113}$ In a letter to Patricia Bartlett before his arrival in New Zealand, he noted that he intended to bring to New Zealand a compilation of material from so-called "video nasties":

I anticipate bringing with me the video tape which I showed to the Members of the House of Commons, House of Lords and to the European Parliament. Before I show this I would have to get clearance from the Customs Authorities to bring it with me and from your Police to ensure no criminal prosecution would arise against me or your organisation. ${ }^{114}$

When screened at the British House of Commons, this compilation tape helped to elicit an extremely negative reaction towards "video nasties" among British MPs, and paved the way for passage of the Video Recordings Act in 1984. Julian Petley describes what occurred as the then Video Recordings Bill was due for its second reading:

What was necessary in the meantime was to ensure it would be supported on the day, and therefore lobbying and agitation continued apace. Undoubtedly the masterstroke was showing MPs... a farrago of 'nasty bits' from various videos, a quite meaningless mish-mash whose only purpose was to shock them into voting for [Graham] Bright's Bill. Of course, it succeeded admirably and provided the press with a field day. ${ }^{115}$

However, events played out rather differently in New Zealand. In a letter to the Ministers of Justice, Police, Internal Affairs and Customs, Patricia Bartlett explained that the Society for the Promotion of Community Standards was bringing Kruger to New Zealand "as a guest speaker from 6 to 12 October 1985", and that the intention was for him to show the "video nasties" compilation tape:

We hope to invite all M.P.s to a screening in the Beehive Theatrette of the presentation shown to the House of Commons and the European Parliament. Attached is Mr Kruger's letter to the Society on this matter. Could you please advise on the legal requirements to arrange such a screening at the beehive at your earliest convenience? ${ }^{116}$

\footnotetext{
${ }^{113}$ AAAC 7536 W5084 Box 44 - Correspondence with the S.P.C.S. 1984-1985.

114 Ibid.

115 Julian Petley, Film and Video Censorship in Contemporary Britain (Edinburgh: Edinburgh

University Press, 2011), 30.

116 AAAC 7536 W5084 Box 44 - Correspondence with the S.P.C.S. 1984-1985.
} 
Ann Hercus, the Minister of Police, wrote to Minister of Internal Affairs Peter Tapsell on the subject of this video, noting that "a request to use the Beehive Theatrette is one which I think needs careful consideration", and that they should "link our officials on this". 117 While it is not clear from the Archives files exactly what happened next, it appears that at some point it was determined that the intended screening constituted public exhibition, and thus came under the scope of the Films Act 1983 and needed to be examined by the Chief Censor. The Society for the Promotion of Community Standards submitted the tape to the Chief Censor with an application for it to be exempted from classification, describing it as "made for police training programme". ${ }^{118}$ However, it was rejected by the Chief Censor for "cruelty, violence [and] sexual violence", thus preventing the planned screening from going ahead. ${ }^{119}$ The Chief Censor's daybook provides a detailed outline of the contents of the tape, describing it as "untitled [edited copy of "horror movies"]", running for twenty minutes and thirty seconds, and including material taken from six films - The Driller Killer, Cannibal Ferox (1981), Faces of Death (1978) Nightmares in a Damaged Brain (1981), Snuff (1975) and I Spit on Your Grave. ${ }^{120}$ The application for exemption had erroneously described the tape as only including five films, incorrectly claiming that one of them was Cannibal Holocaust, and failing to mention Nightmares in a Damaged Brain and Snuff. ${ }^{121}$ This lack of care over the description of the tape suggested that as in the UK, the concern over "video nasties" among groups such as the SPCS was not about any particular individual film titles, but was more concerned with demonising an ill-defined "type" of film in an attempt to foment moral panic. This bears some similarity to the way that for those opposed to "video nasties" in the United Kingdom, "the specific nasty titles began to take second place to the idea of evil horror films". ${ }^{122}$

Both Arthur Everard and the two Deputy Chief Censors viewed the tape, although the daybook notes were not taken by Everard himself, but by Deputy Chief Censor Sarah Ingram. As usual, these notes were mostly descriptive, although there is a comment

\footnotetext{
117 lbid.

118 AAAC W4156 Box 5 - Pressure Groups - Society for the Promotion of Community Standards General 1979-1986.

${ }_{119}$ ADNB 24958 W5848 Box 32 - Register of Classification Decisions 1985-1986.

120 ADNB 23133 W5730 Box 220 - Daybooks of Chief Censor of Films - 4/9/85 to 4/4/86.

${ }^{121}$ AAAC W4156 Box 5 - Pressure Groups - Society for the Promotion of Community Standards General 1979-1986.

122 Egan, 5.
} 
about a scene from the pseudo-documentary Faces of Death involving a monkey's brains being eaten that "monkey head looks artificial" - the scene was indeed faked for the film although presented as though it was real. ${ }^{123}$

However, despite their generally descriptive nature, a note at the end of the daybook notes provides a revealing insight into the censors' reasoning behind the ban on the tape, which was not made public at the time:

[D]iscussed at great length intentions of film.....regarding film as we do any other: it is impossible to cut, presents material out of context, is gratuitous, injurious to the public good in that it misrepresents films and genres (\& may bring about unjustified clampdown) $)^{124}$

While the last part of this explanation seems on the surface to be an unusual justification for a ban, the overall reasoning is consistent with that for other films such as I Spit on Your Grave, where Everard explained in a letter to Women Against Pornography that "the treatment of the material is just as important as its content, the theme cannot be considered in isolation from the way it is presented".

A significant point to note about this compilation tape is that even though it contained excerpts from only six films, and Sarah Ingram's notes in the daybook suggest that it "misrepresents films and genres", one thing it does accurately represent is the diversity of the films that came under the "video nasties" label, and thus the problematic nature of the label itself. Martin Barker notes that there are several major sources of the films labelled as "video nasties":

Some are from a sub-branch of the Italian film industry, a branch which is quite open about making violent films...The others come from the USA, and are a mixture of films produced for the 'drive-in' market....Others, though, are the products of younger film-makers, on the fringes of the big time, working on low budget and outside corporate respectability. This last group has always been more aware and responsive to social and political pressures. ${ }^{125}$

All three of these categories are represented in the compilation tape, with Cannibal Ferox and Nightmares in a Damaged Brain from the Italian exploitation tradition, Faces of Death, Snuff and I Spit on Your Grave being American "grindhouse" films, and The Driller Killer being an early work of Abel Ferrara, who would go on to make films starring major Hollywood actors including King of New York (1990) with Christopher

\footnotetext{
${ }^{123}$ ADNB 23133 W5730 Box 220 - Daybooks of Chief Censor of Films - 4/9/85 to 4/4/86.

124 Ibid.

${ }^{125}$ Barker, "'Nasties': a problem of identification," 105-106.
} 
Walken and Bad Lieutenant (1992) with Harvey Keitel. Kate Egan notes that "a mishmash of films with different production contexts, and released chronologically in their native countries" being grouped together led to "a wholesale collapsing of horror and exploitation production history"126, a point perhaps recognised by New Zealand's film censors who argued that the tape "misrepresents films and genres".

Following the ban on the tape, Patricia Bartlett wrote to Arthur Everard making an application "under s17 of the Films Act for a variation of your classification, since the purpose of importing the videotape is for a specified exhibition". ${ }^{127}$ However, Everard replied that that there was "nothing new" in Bartlett's letter "to cause me to reconsider my earlier decision", and the tape remained banned. ${ }^{128}$ Press coverage of the decision to ban the tape focused on the concept of "pornography" rather than violence, even though the tape contained no sexually explicit content. The tabloid NZ Truth commented on Patricia Bartlett's reaction to the ban with an article entitled "Filthy video ban angers anti-porn crusader", describing the tape as "20-minutes of porn". ${ }^{129}$ Other newspapers used similar language, with The Dominion featuring an article entitled "Porn ban criticised by women", discussing Women Against Pornography's reaction to the Chief Censor's decision. ${ }^{130}$

In the case of this video compilation, campaigners for stricter censorship such as the Society for the Promotion of Community Standards expressed rather different views than usual on the subject. A report in NZ Truth quoted Patricia Bartlett as regarding the ban as "unjust and improper", and that Everard was "plac[ing] himself above Members of Parliament in the matter of censorship" by banning the tape, although Bartlett made no comment on the fact that she would appear to be placing herself "above" the wider general public whom she believed would be negatively affected by the material on the tape. ${ }^{131}$

National Party MP Graham Lee was also opposed to the ban, arguing that "[a]nything that could affect the social interests of the country should be able to be viewed by

\footnotetext{
126 Egan, 51.

127 AAAC W4156 Box 5 - Pressure Groups - Society for the Promotion of Community Standards General 1979-1986.

128 Ibid.

129 NZ Truth, 29 October 1985.

130 The Dominion, 8 October 1985.

131 NZ Truth, 29 October 1985.
} 
MPs". ${ }^{132}$ Women Against Pornography was also reportedly "angered" by the Chief Censor's decision, with their spokeswoman Ruth Charters arguing that "Mr Everard is using censorship in its real sense - to suppress the exchange of ideas that arise out of informed discussion". ${ }^{133}$

As he had in the cases of I Spit on Your Grave and The Driller Killer, Minister of Internal Affairs Peter Tapsell supported the decision of the Chief Censor and did not question Everard's professionalism. In response to a correspondent who suggested that Everard had "interfered" by banning the compilation tape, Tapsell noted that under the legislation the Chief Censor had to consider the "dominant effect" of a film, and that this was the reason for the ban:

\footnotetext{
The video tape submitted by the Society for the Promotion of Community Standards consists of a compilation of violent excerpts from various video tapes shown out of context from the original films where they had some meaning. The whole effect was, I understand, one of unremitting cruelty and violence of an unacceptable level. Precisely because of the artificial and distressful nature of this tape, it could be expected to encounter censorship difficulties. ${ }^{134}$
}

Tapsell also reiterated his support for the view on the link between media violence and real-life violence also held by Arthur Everard, stating that "[i]t has not been proven that there is a link between the visual media and anti-social behaviour in society". ${ }^{135}$

Since the SPCS could not show Kruger's compilation tape, they instead chose to show a "video nasty" that had in fact been passed for public exhibition by the Chief Censor, The Driller Killer. In a letter to Patricia Bartlett, Arthur Everard explained that if a public screening of The Driller Killer was being undertaken, "it must be screened so that at least $95 \%$ of the total material (picture and sound) is exhibited". ${ }^{136}$ However, this intended public screening was not able to go ahead, as the distributors of the film "wanted \$5000 for screening rights". ${ }^{137}$ In the end, The Driller Killer was screened in a private hotel room, with 28 MPs and the news media being invited by Patricia Bartlett

\footnotetext{
132 Auckland Star, 4 October 1985.

133 Evening Post, 8 October 1985.

${ }^{134}$ AAAC 7536 W5169 Box 16 - Chief Censor and Departmental Responsibility - Video Correspondence 1983-1985.

$135 \mathrm{lbid}$.

${ }^{136}$ AAAC W4156 Box 5 - Pressure Groups - Society for the Promotion of Community Standards General 1979-1986.

137 The Dominion, 11 October 1985.
} 
- although while 12 members of the media attended, the only MP to attend was National Party MP John Banks. ${ }^{138}$

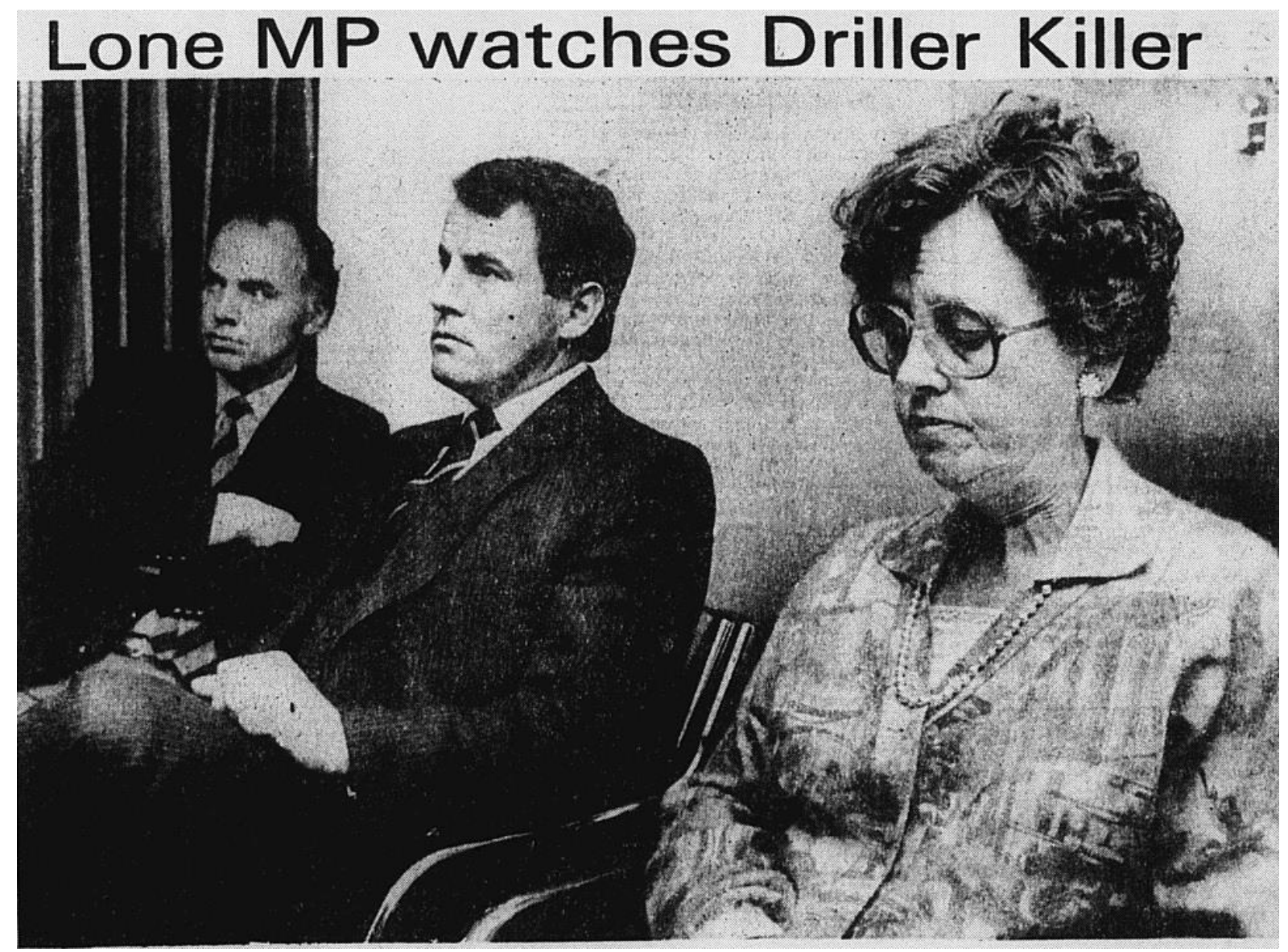

Figure 3: Photograph from The Dominion, 10 October 1985, depicting (from left to right) Peter Kruger, John Banks and Patricia Bartlett watching The Driller Killer.

A contemporary news report noted that " $[t]$ he fast-forward switch was liberally used to bypass what could fairly be described as most of the boring bits to concentrate on four of the 12 killings that sprinkle the movie", an approach that would have not been legally possible with a public screening. ${ }^{139}$ The SPCS's newsletter noted that the ban on the compilation tape meant that they were "obliged to show extracts of video violence under hastily rearranged alternative conditions in Mr. Kruger's hotel room, as a private screening". ${ }^{140}$ In the same newsletter, the SPCS reported that Kruger was "surprised

\footnotetext{
138 The Dominion, 10 October 1985.

139 The Dominion, 10 October 1985.

140 Newsletter No. 55, Society for the Promotion of Community Standards, November 1985.
} 
to learn" that The Driller Killer was legally available on video in New Zealand, and that "the U.K. police became very aware of the "copycat syndrome" resulting from this tape". ${ }^{141}$ Kruger's own expressed view on media effects appeared to mirror this simplistic view - in a report in the New Zealand Herald entitled "Evil Crimes 'Copycat of Videos'”, Kruger stated:

We are having some of the most wicked and evil crimes in England. I think some are attributable to the videos. I cannot prove it, but you read regularly in the press that people convicted of murder had previously been watching videos....From our point of view, videos like Driller Killer will lead to incidents as in Northern Ireland where kneecapping is being done by drills and the like ${ }^{142}$

In another article in the Christchurch Star, Kruger is quoted as saying "[f]rom the police point of view our concern was very much about the copycat syndrome". ${ }^{143}$ However, Peter Tapsell noted in a letter the following year that he felt Kruger did not necessarily believe in such a simplistic view when pressed on the subject, stating that "[n]either did Mr Kruger, when I spoke with him, make a case of his being aware of any conclusive research on the effects of video tapes." 144

\section{The "video nasties" compilation tape - analysis}

As with most of the case studies I have examined, the discourse around the censorship of Peter Kruger's compilation tape did not emphasise manifest content, but took place in a discursive space outside of what was simply on the tape itself. Bartlett and Kruger were less concerned with the specific acts of violence depicted on the tape than with the idea of horror films perceived to be gratuitously violent, and the fact that some of the individual films which were excerpted from had been passed uncut in New Zealand illustrates that the issue was not merely the content itself, but the cumulative impact of viewing it in this way - the "dominant effect" rather than the effect of any single scene. However, in assessing the perceived impact of the compilation tape, Chief Censor Arthur Everard and his two Deputy Chief Censors interpreted the concept of

\footnotetext{
141 lbid.

142 New Zealand Herald, 7 October 1985.

${ }^{143}$ Christchurch Star, 15 October 1985.

144 AAAC 7536 W5169 Box 16 - Chief Censor and Departmental Responsibility - Video Correspondence 1983-1985.
} 
"injurious to the public good" in a way that can be perceived as rather unusual and unique, as it was seen by the censors as potentially swaying opinions in favour of stricter video censorship, and this was an impact that was potentially "injurious to the public good". This suggests that like Mad Max, this was a rare case where very specific circumstances, rather than purely general principles, were a partial justification for a ban - the potential "unjustified clampdown" on home video that might result.

In examining the way in which the film censors took into account issues of viewing context, it is also arguable that the decision to ban the tape from public exhibition was very much in line with the rationale for other decisions, rather than an anomaly or outlier. While the intended audience for the tape was Members of Parliament, the censors treated the planned exhibition as a standard public screening. This is consistent with the way other films would be treated while Everard was Chief Censor, and marked something of a shift from Tunnicliffe's era, when films were sometimes given special consideration for film festivals and the like. For example, when Everard considered Jean-Luc Godard's Hail Mary, the fact that it was intended to be screened at a film festival was not a significant consideration in his decision to pass it uncut.

In an unusual situation, the banning of the video nasties compilation tape put the Chief Censor and lobby groups such as the SPCS and Women Against Pornography in opposite positions to that which they usually found themselves in, with the lobby groups opposing the Chief Censor's decision to not permit public exhibition of the tape. However, what did not change was that the views of the SPCS and other procensorship campaigners were not given discursive legitimacy - Minister of Internal Affairs Peter Tapsell supported Arthur Everard in his ban of the compilation video in the same way he had supported his decision to pass controversial films such as I Spit on Your Grave and The Driller Killer. Just as the views of those protesting against those films were not afforded legitimacy due to their perceived misrepresentation of those films, the misrepresentation of the "video nasties" in the compilation video was acknowledged as such and not taken uncritically and at face value.

While the issue of cinematic realism in relation to the various film excerpts on the tape was not a factor in the discourse surrounding it, the accuracy of the tape in terms of how it represented the so-called "video nasties" was, and the way it "misrepresents films and genres". This is somewhat similar to Deputy Chief Censor Diane Wren's 
reasoning for banning the film Scum because of its "degree of distortion of the truth relating to institutional realities"145 - it can be argued similarly that a factor in the decision was the video compilation's "degree of distortion of the truth relating to video nasties". Such reasoning was rather an anomaly for the film censor's office under Everard, but would emerge as a factor in some of the decisions of the Video Recordings Authority and Video Recordings Board of Review. With Patricia Bartlett being forced to resort to a more "accurate" portrayal of video nasties by showing a single film (albeit reportedly with much of the non-violent content fast-forwarded), this lacked the impact that the compilation tape had in the United Kingdom, and indeed when home video legislation did emerge in New Zealand eventually in 1987, it was much more moderate than that which had been passed in the UK three years before that, although this was not the only factor involved.

\section{The passage of the Video Recordings Act 1987}

Even before Arthur Everard's term as Chief Censor, the Society for the Promotion of Community Standards had been attempting to sway politicians towards strict censorship for home video. However, during this time they were more concerned with sexual content on home video than the violence of the "video nasties". For example, in March 1983 Patricia Bartlett wrote to Allan Highet concerned about "the flood of pornographic video tape films which have been coming into the country for about two years", and to Comptroller of Customs P.J. McKone expressing pleasure that Customs "had seized 3,000 pornographic tapes last year", but still concerned about titles advertised in the Truth, listing only films such as the soft-core Electric Blue series and others with titles such as Disco Sex Fever and Nude Jello Wrestling. ${ }^{146}$ This situation changed in the following years, with violent "video nasties" such as I Spit on Your Grave and The Driller Killer becoming more the subject of the SPCS's attention.

While the United Kingdom had passed video legislation in 1984 at the height of the "video nasties" scare, New Zealand waited another three years for the Video

\footnotetext{
${ }^{145}$ AAAC W4442 Box 8 - Controversial/Interesting \& Some Rejected Films - Scum 1980.

${ }^{146}$ AAAC W3628 Box 3 - Chief Censor and Departmental Responsibility - Video Correspondence 1980-1983.
} 
Recordings Act, which was passed on 3 June 1987 and came into force on 1 July 1987. ${ }^{147}$ This legislation was much more moderate and less restrictive than that which emerged in the UK, and was consistent with official discourse of both the current Labour government, with Peter Tapsell as Minister of Internal Affairs, and the previous National government, with Allan Highet as Minister of Internal Affairs. Indeed, Highet had stated in a speech to the SPCS in 1982 that his government was "reluctant to impose greater restrictions on what is viewed in a private residence" than in the cinema, and that while he recognised that there was some concern about films which had been banned by the film censor being available on video, he "accept[ed] that these video tapes are not for public viewing". ${ }^{148}$ Both before and after the passage of the Video Recordings Act, his successor Peter Tapsell stressed that its intention was not to heavily restrict video recordings, but to provide information to consumers about the content of videos so they could make an informed decision on whether or not to view them. For example, in late 1985 he wrote to one correspondent arguing that the government's proposed video legislation "include[s] the introduction of a system of labelling to advise consumers as to the content of video tapes", and went further to suggest that "[w]ith regard to television and video tapes for private viewing, you do have an immediate course of action available, that is, you can switch the television or VCR off". ${ }^{149}$ Writing to the Secretary of the Video Association of New Zealand not long after the Video Recordings Act had come into force, Tapsell stated:

The purpose of the labelling is to highlight to the consumer the rating or classification, thereby the sensitivity, of the video content, whilst the consumer is first selecting the video and then perusing the synopsis of the film story. 150

This level of continuity over time contrasted strongly with the UK situation concerning "video nasties". As Martin Barker notes, before the 1983 British general election, the UK government's position on video censorship had been much the same as that in New Zealand:

Up until then, the government's response had been clear: legislation in this area had been very difficult, for many reasons; the BVA [British Videogram Association] had taken the initiative, and

\footnotetext{
147 Video Recordings Act 1987.

148 AAAC 7536 W5084 Box 26 - Correspondence with the S.P.C.S. 1982-1994.

149 AAAC 7536 W5084 Box 43 - General Correspondence (including complaints) 1985-1986.

150 AAAC 7536 W5169 Box 3 - Videos for Private Viewing - Video Recording Regulations 1985-1987.
} 
it is better if it can be sorted out voluntarily than by law; the government would rather try the voluntary scheme before contemplating the more messy path of state control. ${ }^{151}$

New Zealand did not experience the change in the prevailing discourse about home video censorship that the UK did, but instead ended up with something of a "hybrid" system, where films classified R16 or below by the Chief Censor were given purely advisory classification labels by the industry-based Film and Labelling Body, and films classified R18, or otherwise seen as requiring some form of restriction, were forwarded to the newly formed Video Recordings Authority.

\section{Chapter summary}

The early years of new Chief Censor Arthur Everard were marked by both continuity and change. There was a significant degree of consistency with their predecessors in the views of both Everard and the new Minister of Internal Affairs, Peter Tapsell, on issues such as media effects and the value of views expressed on controversial films by those who either had not seen them or significantly misrepresented them. However, the SPCS's description of Everard's early decisions as "the most permissive on record", while clearly intended in a pejorative manner, has some degree of truth to it. While Tunnicliffe and his deputies had passed Last Tango in Paris but had been willing to ban low-budget exploitation films such as The Texas Chain Saw Massacre and The Hills Have Eyes, Everard appeared to take a much more even-handed approach, focusing much more firmly on whether or not a film could be considered "injurious to the public good" irrespective of its quality. Notably, while Everard did ban the "video nasties" compilation tape, and would also ban some video pornography, no mainstream cinema films were banned during his tenure as Chief Censor from 1984 to 1990 . However, the new home video censorship regime, overseen by the newly constituted Video Recordings Authority and Video Recordings Board of Review, would take a much less dispassionate and evidence-based approach to the concept of "injurious to the public good", as demonstrated in the following chapter.

151 Barker, "Nasty politics or video nasties?", 9. 


\section{Chapter Five: Chief Censor Arthur Everard, 1987-1990}

\section{Chapter overview}

This chapter continues to discuss film censorship in New Zealand in the 1980s under Chief Censor Arthur Everard, as well as discussing the workings of the newly formed Video Recordings Authority and Video Recordings Board of Review in the first few years after their inception in 1987. For the film censors, religion and censorship controversy became a significant issue again for the first time since Life of Brian, with Jean-Luc Godard's Hail Mary and Martin Scorsese's The Last Temptation of Christ facing protests and complaints because of the perceived offense which they caused to some religious groups. Both were passed uncut by the Chief Censor, although the decision of the censors on the former was the subject of a court case which resulted in a ruling that the censor had erred on a matter of legal procedure. Another court case followed after this, brought by the Society for the Promotion of Community Standards over two pornographic videos, which resulted in a similar ruling. However, no other court cases followed these and it appears that they did not set any notable precedents. During this same period, the Video Recordings Authority and the Video Recordings Board of Review had begun to classify and sometimes ban video recordings. Both these new censorship institutions took a stricter approach than the film censors, with greater use of excisions and bans, and the use of rationales that had not been used by the film censors for some years, such as the idea of "copycat" behaviour. The analysis suggests that these significant differences between the practices of film and video censorship are attributable to the lack of established practices and institutional continuity in the case of the video censorship authorities.

A number of key themes emerge from the case studies examined in this chapter. These include the role of "imagined" versions of films in censorship controversy, discursive legitimation and the way certain voices were privileged over others, and the concept of "censorship as a process" identified by Annette Kuhn. In the case of video 
censorship, a number of factors were involved in the rationalisation of censorship decisions that had not been so prevalent in film censorship, particularly the issue of perceived artistic merit (or otherwise) of films on video, a conflation of the ideas of "injurious" and "offensive" rather than the clear division between the two that the film censors had maintained, and the role of the imagined audience in coming to censorship decisions.

\section{Hail Mary and The Last Temptation of Christ - historical narrative}

After the furore over Life of Brian in 1979 and 1980, there was little controversy in New Zealand surrounding the censorship of cinema films and religion in the first half of the 1980s. However, in 1986 and 1988 two films also notable for worldwide condemnation over their alleged blasphemy faced protests and complaints in this country - Jean-Luc Godard's Hail Mary (original French title Je vous salue, Marie, literally "I salute you, Marie") in 1986 and Martin Scorsese's The Last Temptation of Christ in 1988. The films are in many ways quite different - Godard's film tells a modern story of a virgin birth with Marie (Mary) as a gas station attendant and Joseph as a cab driver, while Scorsese adapts Nikos Kazantzakis's controversial 1955 novel which portrays Jesus as a flawed human being who is "tempted" by the promise of life as an ordinary man while dying on the cross. As Sandra Laugier suggests, "[w]hat is remarkable, however, is the similarity of the scandals" - while both films were condemned for being blasphemous or even "pornographic", it was perhaps the fact "Mary and her son [were] seen as ordinary human beings...who would then have nothing extraordinary about them" that prompted so much virulent condemnation. ${ }^{1}$ In a critique of Scorsese's film, Lloyd Baugh suggests that the "exaggerations in depicting Jesus' humanity...in effect exclude his divinity". ${ }^{2}$ As in the case of Life of Brian, the perceived failure of these two

\footnotetext{
1 Sandra Laugier, "The Holy Family." In Jean-Luc Godard's Hail Mary: Women and the Sacred in Film, edited by Maryel Locke and Charles Warren (Carbondale: Southern Illinois University Press, 1993), 27.

2 S.J. Lloyd Baugh, "Martin Scorsese's The Last Temptation of Christ: A Critical Reassessment of Its Sources, Its Theological Problems, and Its Impact on the Public." In Scandalizing Jesus? Kazantzakis's The Last Temptation of Christ Fifty Years On, edited by Darren J.N. Middleton (New York: Continuum, 2005), 187.
} 
films to portray people whom many held sacred in a sufficiently reverent manner led to strong and often emotive protests.

Godard's film proved extremely controversial on its initial release in Europe and the United States, although as David Sterrit suggests, the "most preposterous aspect of the Hail Mary controversy was its irrelevance to the film itself, as protestors had generally not seen the film and "conveyed the misconception that it represented a major flashpoint in the movie industry's treatment of religion". ${ }^{3}$ There were pickets against the film in France, and Godard himself even asked his Italian distributor to withdraw the film from screening due to the strength of the Vatican's reaction to the film, although the distributor refused this request. ${ }^{4}$ Godard even wrote to the Vatican after the Pope had personally expressed his opposition to the film. In this letter he argued that his film was "sincere but imperfect" and even suggested that "[i]t thus so happens that the Holy Father was one of the screenwriters of this film". ${ }^{5}$ In the United States, the film saw major protests in Boston and Chicago, and despite the First Amendment protection which cinema enjoyed, some efforts were made to prevent screenings of the film, although these were ultimately unsuccessful. ${ }^{6}$ The film eventually arrived in New Zealand in 1986 for film festivals in Auckland and Wellington. However, as was the case with many controversial films, complaints about the film preceded its arrival, based on second-hand accounts and hearsay rather than actual viewing of the film - an "imagined" version of the film, rather than the actual film itself. Letters from individual members of the public often included very extreme language, such as a letter to Everard by Toni Dunlop, who concluded:

But this, this film, is effluent, is sewage. Please, don't pass it for screening anywhere in this still good and decent country! ${ }^{7}$

Another correspondent referring to a condemnatory report on the film in the Catholic newsletter Christendom, argued:

\footnotetext{
3 David Sterritt, The Films of Jean-Luc Godard: Seeing the Invisible (Cambridge: Cambridge University Press. 1999), 168

${ }^{4}$ Maryel Locke, "A History of the Public Controversy." In Jean-Luc Godard's Hail Mary: Women and the Sacred in Film, edited by Maryel Locke and Charles Warren (Carbondale: Southern Illinois University Press, 1993), 3.

${ }^{5}$ Locke, 6.

${ }^{6}$ Sterritt, 167.

${ }^{7}$ AAAC 6799 W4516 Box 15 - Controversial, Interesting and Rejected Films - Hail Petition 1986-1990.
} 
It is clear from a well-documented report that I have read that it is a porno-blasphemous film designed to insult and defile the time honoured pure and respected personage of the Blessed Virgin Mary. ${ }^{8}$

The term "pornoblasphemous" had been used in the original newsletter report, with the film being denounced for its allegedly "Obscene Images" and "Vulgar Dialogues" as well as its perceived blasphemous content. Such content was made to appear far worse than it actually was by the refusal of the newsletter's publishers to explicitly outline it on grounds of its supposed extreme offensiveness - the "vulgar language" is described as having "such coarseness that it would be improper to reproduce here", and the film is described as "so offensive that we dare not print a still of it". ${ }^{9}$

Everard received enough of these letters that, as Bernard Tunnicliffe had done for Life of Brian, he prepared a "form" letter to sign in reply to them, simply arguing that he had "no power to reject a film without having seen it", and he would consider it when it was submitted to the Chief Censor's office. ${ }^{10}$ Everard also received a letter signed by the President of the NZ Catholic Bishops Conference, on behalf of the Bishops of several major cities, explaining that the film "can only be seen as a direct attack on Mary" which "amounts to blasphemy", although they were basing this view on what they had "learned from those who have viewed it in Europe". ${ }^{11}$ There was also a petition entitled the "Ave Maria Reparation and Protest Petition", signed by over 12,000 people, accompanied by a letter whose writer argued that he was "certain that all signatories see their views faithfully interpreted by the Bishops' stand against the film". ${ }^{12}$ The wording of the petition itself stated that the petitioners "respectfully request that [Everard] ban this film" as they were "firmly convinced that the said film gravely offends and denigrates their religious beliefs and those of the vast majority of New Zealand Christians". 13

However, as had been the case with a number of films before, these views on Hail Mary which were not based on direct first-hand knowledge of its content were not given discursive legitimacy by the Chief Censor, and did not significantly factor into his

\footnotetext{
${ }^{8}$ AAAC 7536 W5169 Box 15 - Chief Censor and Departmental Responsibility - Hail Mary 1986-1988.

${ }^{9}$ Christendom, February 1986.

${ }^{10}$ ADNB 23136 W5848 Box 6 - 'Hail Mary' Public Opinion 1985-1986.

${ }^{11}$ AAAC 7536 W5169 Box 15 - Chief Censor and Departmental Responsibility - Hail Mary 1986-1988.

12 lbid.

13 lbid.
} 
decision-making process. The film was passed by Arthur Everard uncut with an unrestricted GA rating and a warning "some content may offend". All three censors were present at the screening on 10 July, which was not always the case for every film the Chief Censor's office examined, but did often occur if a film was considered potentially controversial or problematic to classify. As well as the censors, a number of members of the general public, reporters including one from Catholic newspaper Zealandia, and members of the National Film Unit attended the screening.

The first public screening in Wellington on 13 July was not accompanied by any protest action, and filmmaker and film critic Costa Botes, who viewed the film at that screening, stated that he thought that it was "difficult to understand what all the fuss has been about". ${ }^{14}$ Catholic newspaper Zealandia reported that the first Auckland screening did see a "small group of protestors", but not "the violence which accompanied protests in Sydney". ${ }^{15}$ In response to an oral question to him as Minister for Internal Affairs on 29 July, Peter Tapsell noted that he did not have the power to prevent the Chief Censor from approving Hail Mary for exhibition with a GA certificate, and provided written supplementary information which further explained his answer. He stressed the independence of the Chief Censor, and noted that while as Minister of Internal Affairs he could withdraw a film from exhibition, it was only if continued exhibition was considered to be "likely to be injurious to the public good". ${ }^{16}$ Tapsell noted that since much of the concern expressed about the film had occurred before the film had been exhibited, this could not be taken into account when deciding to exercise his power to withdraw the film from exhibition, as well as being "nearly all based on overseas reports and the publicity the film has received rather than on the correspondents' personal viewing and analysis". ${ }^{17}$

However, it was the events that followed the film festival screenings, after the film was no longer actually being exhibited in New Zealand cinemas, that made Hail Mary a significant part of New Zealand film censorship history. As Des Freedman notes, in the case of media policy and its implementation, it is frequently the case that "[e]very step of the way is marked by fierce competition for, or deployment of, resources,

\footnotetext{
14 The Dominion, 14 July 1986

15 Zealandia, 3 August 1986.

${ }^{16}$ AAAC 7536 W5169 Box 15 - Chief Censor and Departmental Responsibility - Hail Mary 1986-1988. 17 Ibid.
} 
influence and power". ${ }^{18}$ Many decisions on controversial films were not simply accepted by those who opposed them, but in the case of Hail Mary, this opposition went further than simply petitions and letters of protest. An application was made to overturn the Chief Censor's decision by three self-described "practising Catholics" who had also organised the petition against the film, and in a 33 page decision in the Wellington High Court, Justice Heron agreed to do so on a specific point of law. ${ }^{19}$ This was that Everard's consultation process had not included "official representatives of the church and laity", and that the screening on 10 July was "inadequate" as it did not include "representatives of the affected group", and that in allegedly failing to take into account views which may have been expressed after an additional consultation involving Catholic representatives, Everard had made "an improper exercise of the statutory discretion he had". ${ }^{20}$ Justice Heron made it clear that he considered this a matter of procedural error, and did not "deal with the merits of the decision to approve the film for exhibition", but instead with the censor's decision-making process. Indeed, Heron suggested that "it may well have been that the censor would have reached exactly the same decision if the proper procedure had been followed". ${ }^{21}$

Arthur Everard's affidavit in the court case regarding Hail Mary provides a detailed insight into the censorship process surrounding this film, and the way in which he came to the decision to pass it with a GA certificate. Everard stated that he chose to "view the film in the absence of any official representative from within the Catholic faith" as he wished to "avoid any suggestion" that he had allowed his judgment "to be overborne by a powerful lobby", and to "distance [himself] from any suggestion of predetermination based on hearsay". ${ }^{22}$ Everard stated that if he was in any doubt over "whether or not the film denigrated Catholics or Christians as a whole", he would then "view the film again in the presence of such representatives". ${ }^{23}$ Everard's rationale for the makeup of the audience invited to view the film was to see the reactions to the film of a "general" audience rather than one specifically including Catholic representatives, as he was "looking for assistance on the question whether the film might denigrate

\footnotetext{
18 Des Freedman, The Politics of Media Policy (Cambridge: Polity Press, 2008), 3.

${ }^{19}$ AAAC 7536 W5169 Box 15 - Chief Censor and Departmental Responsibility - Hail Mary 1986-1988.

20 lbid.

$21 \mathrm{lbid}$

22 Ibid.

$23 \mathrm{lbid}$.
} 
Catholics by reason of the perception of Catholics it conveyed to others". ${ }^{24}$ However, Everard explained that "by the time the screening had ended", he had come to the opinion that the film did not denigrate Catholics or any other Christians. ${ }^{25} \mathrm{He}$ noted that none of those attending the screening had claimed that Hail Mary denigrated any class of the general public, but that even if they had done, in this particular case his own decision, arrived at during viewing of the film, would have taken precedent, and he would thus have "rejected the claim in favour of [his] own opinion to the contrary". ${ }^{26}$ Deputy Censor Anthony Hill prepared a draft commentary on Justice Heron's decision, which was forwarded to Deputy Secretary John Sullivan at the Department of Internal Affairs, suggesting that the decision gave too much discursive power to any perceived "affected group" at the expense of the censor's professional judgement. ${ }^{27}$ Hill argued that the decision "undermines the professionalism and objectivity of the Chief Censor", and "requires "representativeness" on the part of personnel that is not feasible". ${ }^{28}$ Hill suggested that the decision "has major implications for the future operations of this Office, the ramifications of which could involve battles in the High Court on parallel lines to this one or compel the Office to consult either "experts" or representatives of groups on a regular basis". Hill suggested four "immediate possibilities" from Heron's decision - appealing against it, complying with the precedents, making an amendment to the Films Act, or "ignor[ing] the decision and precedents and risk[ing] a further court case with the next controversial film". ${ }^{29}$ An undated file note by Hill noted that Sullivan visited the Chief Censor's office to discuss Hill's commentary, and he argued that he "does not see any major precedents arising from this case", and that they were "perfectly correct in proceeding as [they] were and awaiting any further court action if it occurred".$^{30}$ It seems that to a large extent, this advice was followed, as between the Hail Mary decision and the passage of new film censorship legislation in 1993, no similar court cases resulted, and while Everard did make reference to Heron's ruling in some of his decisions on controversial films, there is no evidence to suggest that he

\footnotetext{
24 lbid.

$25 \mathrm{lbid}$.

$26 \mathrm{lbid}$.

$27 \mathrm{Ibid}$.

$28 \mathrm{lbid}$

$29 \mathrm{lbid}$

${ }^{30}$ AAAC 6799 W4516 Box 15 - Controversial, Interesting and Rejected Films - Hail Petition 19861990.
} 
undertook any consultations which were specifically prompted by the Hail Mary case. ${ }^{31}$ Reflecting back on the Hail Mary case, Everard considered the judge's decision to be overly pedantic and "splitting hairs", and that "it's a wonder he didn't say, well we should have considered how many angels could dance on the head of a pin". He also suggested that the title of the film was perhaps one of the main factors leading to the controversy, and if it had been called something else, it may not have attracted so much attention. ${ }^{32}$ Indeed, the organisers of the petition against the film, in their letter to Everard accompanying the petition, highlighted the significance of the "Hail Mary" prayer to Catholics, and noted that they felt that "[w]hen people in the community speak or think of "Hail Mary", they think of Catholics". ${ }^{33}$

While the Hail Mary case did not result in further court cases based on the lack of consultation with an "affected" group by the Chief Censor, the following year did see another court case which resulted in a somewhat similar ruling, although based on a different reasoning. In 1987, the Society for the Promotion of Community Standards brought a case to court over the decision of the Chief Censor's office to pass two pornographic videos, Pretty as You Feel and Inches, both uncut with an R18 classification. This was ostensibly for public exhibition, as there was still no formal video censorship regime at this stage. Everard had begun to pass material containing explicit and unsimulated sex, provided it was non-violent and consensual, in early 1986, two years after his assumption of the role of Chief Censor. Indeed, when examining a number of uncut versions of such tapes in 1985 that had been passed in pre-cut form, he noted in the daybook:

In all cases there is different or extra material, [including] penetration, ejaculation, fellatio, cunnilingus etc etc....At present there is no way we could release these uncut as R20s. ${ }^{34}$

The case of Pretty as You Feel and Inches resulted in a similar ruling to that in the case of Hail Mary; setting aside the decisions on a matter of procedure, rather than finding that they were inherently incorrect. The two videos were in fact examined by

\footnotetext{
${ }^{31}$ Everard's successor, Jane Wrightson, took a more cautious approach, and in the case of some of her formal consultations on individual films, the precedent of this case did appear to have been a specific concern.

32 Interview with Arthur Everard.

${ }^{33}$ AAAC 7536 W5169 Box 15 - Chief Censor and Departmental Responsibility - Hail Mary 1986-1988.

${ }^{34}$ ADNB 23133 W5730 Box 219 - Daybooks of Chief Censor of Films - 23/7/85 to 16/1/86. These videos were restricted to trade screenings rather than being banned, but were not passed for public exhibition at that time.
} 
the Deputy Chief Censors, Sarah Ingram examining Pretty as You Feel (which was heterosexual pornography) and Anthony Hill examining Inches (which was gay pornography). ${ }^{35}$ Their daybook notes do not highlight any aspects of concern in the films, and like most of the daybook notes during Everard's tenure as Chief Censor, are largely simply description of the videos' content. The judge in the case, Justice McGechan, argued that the Chief Censor "misinterpreted the concept of injury to the public good by proceeding on the basis that matters of sex could never be injurious to the public good if non violent and consensual and without anti-social treatment, and misdirected himself accordingly." ${ }^{6}$ However, McGechan acknowledged that neither video features any violence or coercion, both of them depicting entirely consensual sex, and that he did not "find the censor's decisions were such as could not reasonably be reached, ie as irrational or perverse". ${ }^{37}$ Both videos were re-examined by Everard himself after the court decision, his daybook notes for both videos explaining that he had taken into account McGechan's decision and chosen to pass each video again as R18 uncut. In the case of Inches, he explained:

I have read (both before and after the examination) J. McGechan's judgement, keeping his comments in mind about injury etc and find that this tape is not injurious, in part or whole, to the public good. Therefore, I consider that the original classification should be applied ${ }^{38}$

Patricia Bartlett attempted to use this case, as well as the Hail Mary decision, as justification to have Chief Censor Arthur Everard removed from office, arguing that:

the Film Censor has been shown to be unable to correctly administer his Act. He should therefore be removed from office and replaced with someone who can interpret what the Act expects and what Parliament intended when the legislation was put in place. ${ }^{39}$

In response, Minister of Internal Affairs Michael Bassett argued that there were no grounds for Everard to be removed from his position, as these were isolated cases:

\footnotetext{
${ }^{35}$ AAAC 6799 W4516 Box 15 - Controversial, Interesting and Rejected Films - Inches/Pretty as You Feel 1986-1987.

36 lbid.

37 Ibid.

${ }^{38}$ ADNB 23133 W5730 Box 235 - Daybooks of Chief Censor of Films - 12/2/88 to 3/10/88.

${ }^{39}$ AAAC 7536 W5169 Box 15 - Chief Censor and Departmental Responsibility - Pretty as you feel Inches 1986-1989.
} 
In the absence of evidence that the Chief Censor similarly misdirected himself in making decisions in respect of other films or videos it must be assumed that such other films or videos classified by him have been properly dealt with.

I do not have the power to either influence the Chief Censor in his decision-making or to remove him from office. The Chief Censor is an independent statutory officer whose position is, rightly I consider, protected from political interference. ${ }^{40}$

In my interview with him, Arthur Everard described his relationship with Bassett, who had taken over from Peter Tapsell as Minister of Internal Affairs, as more difficult than with Tapsell, with the new Minister upset by some decisions which Everard had made, such as passing The Last House on the Left uncut. ${ }^{41}$ However, at least in his public statements and correspondence, Bassett was similarly supportive of Everard's professionalism and independence, suggesting a significant degree of institutional continuity in the position of Minister of Internal Affairs.

In a file note prompted by a query from the New Zealand Herald about Pretty as You Feel and Inches, Everard himself explained that he felt that the judge's decision "was not the overwhelming success for S.P.C.S. that Patricia Bartlett had been claiming in previous statements. (In fact, of course, it was mostly favourable to this Office.)"42

Two years after Hail Mary, Martin Scorsese's The Last Temptation of Christ, came before the New Zealand film censors, a film with the potential to test the precedent set by the Hail Mary court case. The film was passed uncut on 19 September 1988, with an RP13 certificate, and the note "content may offend". This decision led to a number of letters of complaint, although the opposition to the film was less than that in the case of Hail Mary, and there was no large nationwide petition. Some of these letters centred around the idea that the film was not a "truthful" representation of Biblical events, and sometimes condemned Everard in extremely emotive language, such as one correspondent who wrote:

\footnotetext{
$40 \mathrm{lbid}$.

${ }^{41}$ Interview with Arthur Everard.

${ }^{42}$ AAAC 6799 W4516 Box 15 - Controversial, Interesting and Rejected Films - Inches/Pretty as You Feel 1986-1987.
} 
Do you not know that one day you and the others in the censoring office will stand before Christ to be judged? He will examine you on the influence you have had on others for or against the living of His Truth. ${ }^{43}$

In the case of this and several other letters, Everard simply noted "no reply" on the letter. However, he did respond to other correspondents who addressed the concept of "denigration" as outlined in the Films Act 1983, many of whom had apparently been prompted to address this point by a report in a SPCS newsletter which quoted from the Films Act and requested that letters be written to the Attorney-General Geoffrey Palmer and to Everard. Perhaps as a result of their lack of success in their procensorship campaigns, the tone of the request seemed to almost feel as though going through the motions, stating simply that "[t]here is no doubt that this film is blasphemous as is clear from the factual report in Time [magazine], and there should be protest". ${ }^{44}$ In defending his decision to these correspondents, Everard stated that as well as following the requirements of the 1983 Films Act, he had taken into account Justice Heron's judgment in the case of the classification of Hail Mary. ${ }^{45}$ However, it does not appear that he engaged in any direct consultation over the decision other than with his fellow film censors. He explained:

This film was examined on Monday 19 September, all three censors being present....

Having taken cognisance of all the above matters, and after a long and vigorous dissection of its content and treatment by all three film censors concerned with it, we decided unanimously that THE LAST TEMPTATION OF CHRIST should be classified RP13, Content may offend. ${ }^{46}$

In a more detailed letter to MP Judy Keall, who had received a letter of complaint from Reverend David Kimpton of Northcote Baptist Church, Everard stressed that denigration of a particular group "may occur to a certain degree", and that "it is not injurious unless it reached a certain level of expression". However, acknowledging the lack of definition of "injurious" in the legislation and the difficulty of determining whether a film did warrant a ban, he noted that "[t]he level at which it becomes injurious is not quantified by the Films Act" ${ }^{47}$ Reflecting back on the concept of "injurious to the public

\footnotetext{
${ }^{43}$ AAAC 6799 W4516 Box 16 - Controversial, Interesting and Rejected Films - Last Temptation of Christ 1988-1989.

${ }^{44}$ Newsletter No. 64, Society for the Promotion of Community Standards, September 1988.

${ }^{45}$ AAAC 6799 W4516 Box 16 - Controversial, Interesting and Rejected Films - Last Temptation of Christ 1988-1989.

46 Ibid.

47 Ibid.
} 
good" in my interview with him, Everard was somewhat more candid about the difficulty of defining it, suggesting that it is 'like judges trying to define 'reasonable' - they don't, because they can't", although he did suggest that it could perhaps be defined as material "likely to lead to changes in attitudes and behaviour which is antisocial". ${ }^{48}$ However, in this case, as in that of Hail Mary, Everard did not feel the need to make a judgment about the level of denigration present as "it was determined that denigration did not occur" and thus the censors "were unable to take into consideration something that did not exist". 49

Everard was supported in his decision by the Minister of Internal Affairs, Michael Bassett, and the Department itself. He noted in response to one complaint "there has been little evidence to show that the public exhibition of "The Last Temptation of Christ" has cause widespread public concern or had an apparent effect on any class of the general public", and thus he was unable to withdraw the film from exhibition as he was "not satisfied that this film is injurious to the public good". 50 In response to several small petitions against The Last Temptation of Christ, totalling less than 100 individuals, B. Richards, on behalf of the Secretary for Internal Affairs, argued that there was "no evidence" that Everard had made his decision "without proper consideration of all the relevant factors as required under the Films Act 1983". ${ }^{51} \mathrm{He}$ also explained that "[b]ecause material in a film may be considered to be offensive by some people, this does not necessarily mean that it is also likely to be injurious to the public good", although as Everard had done, he did not define when something may cross over from merely "offensive" to "injurious". ${ }^{22}$ Richards did make note of the Hail Mary court decision, but stressed the point that "the case did not deal with the merits of the decision to approve the film in question for exhibition", and did not suggest that Everard had erred in not undertaking a consultation involving those "affected" by the film. ${ }^{53}$

\footnotetext{
48 Interview with Arthur Everard.

${ }^{49}$ AAAC 6799 W4516 Box 16 - Controversial, Interesting and Rejected Films - Last Temptation of Christ 1988-1989.

50 AAAC 7536 W5169 Box 15 - Chief Censor and Departmental Responsibility - Hail Mary 1986-1988. 51 Ibid.

${ }^{52}$ AAAC 6799 W4516 Box 16 - Controversial, Interesting and Rejected Films - Last Temptation of Christ 1988-1989.

${ }^{53}$ AAAC 7536 W5169 Box 15 - Chief Censor and Departmental Responsibility - Hail Mary 1986-1988.
} 
In response to a letter of support for his decision, Everard thanked the correspondent as "such compliments are as welcome as they are rare", and expressed his dismay at the way in which complaints about controversial films so often played out:

[T] he great majority of letters to this office demanding that the film be rejected are from complainants who have never seen it and have no intention whatsoever of doing so.

As usual, once a controversial film has been released and the preceding publicity about it has been exposed as unfounded hyperbole, everything quietens down - until the next time. ${ }^{54}$

The controversy definitely did "quieten down", and The Last Temptation of Christ did not result in any new court cases or appeals to the precedent set by the Hail Mary case.

A few months after the controversy around The Last Temptation of Christ, in January 1989, the Ministerial Committee of Inquiry into Pornography, which had been convened in 1987, published its report. The full significance of this development in New Zealand film and video censorship would not be realised until the passage of the 1993 Films, Videos and Publications Classifications Act, which was in part based on the Committee's recommendations. Despite its name, the Committee looked more broadly at New Zealand's existing censorship legislation and how it might be changed rather than simply looking at the issue of pornography - indeed, their "terms of reference" did not use the term "pornography" at all, but did make less specific reference to the issue of dealing with "prohibited or restricted material". ${ }^{55}$ The most significant recommendation of the Committee was that the existing censorship legislation, split between the Indecent Publications Act, Films Act and Video Recordings Act, be "replaced by one comprehensive statute dealing with the classification and rating of the works to which those Acts currently apply". ${ }^{56}$ The result of this recommendation was the 1993 legislation. Also particularly notable was the recommendation that certain specific types of material be considered either "likely to be injurious to the public good" or be "presumed to be likely to be injurious to the public good", an approach which the Films Act and Video Recordings Act did not take. ${ }^{57}$ The

\footnotetext{
${ }^{54}$ AAAC 6799 W4516 Box 16 - Controversial, Interesting and Rejected Films - Last Temptation of Christ 1988-1989.

55 Joanne Morris, Hilary Haines and Jack Shallcrass, Pornography: Report of the Ministerial Committee of Inquiry (January 1989), 11.

56 Ibid., 11

57 lbid., 11
} 
latter category included "visual material" which "advocates or condones" urolagnia, something that would factor into censorship of pornographic videos by both the Video Recordings Authority and the Video Recordings Board of Review before the legislation was actually changed to reflect this recommendation. ${ }^{58}$

\section{Hail Mary and The Last Temptation of Christ - analysis}

As in the case of the controversy surrounding Life of Brian, there was a significant discrepancy between the manifest content of Hail Mary and The Last Temptation of Christ and the way in which they were described in the complaints about them. It is often the case that complaints and controversy surrounding films relate more to an "imagined" version of the film, based on second-hand accounts and hearsay rather than actual first-hand knowledge, but in the case of films which are controversial for perceived blasphemy and religious offense, this seems even more pronounced. Indeed, Hail Mary contains little overt religious imagery, and despite extreme language used to describe it such as "pornoblasphemous", is not in any way sexually explicit either. Despite the claim in the newsletter Christendom that the film was "so offensive that we dare not print a still of it", much of the film consisted of uncontroversial natural imagery. As Yosefa Loshitzky argues, this represents a contrast with Godard's earlier films:

The Godardian modernist iconography, which borrowed bits of traffic signs, neon, advertisements, and cartoons from the urban and industrial milieu, was replaced in Hail Mary by natural signs: a moon, a sun, water, and apples. ${ }^{59}$

Charles Warren suggests that it is possible for the film to simply be taken as a modern story with some parallels to religious figures, as the characters "do not speak of the Bible or the resemblance of their lives to biblical events". ${ }^{60}$ In addition, Hail Mary was preceded by a short film, The Book of Mary (Le livre de Marie), directed by Anne-Marie

\footnotetext{
58 lbid., 11

59 Yosefa Loshitzky, The radical faces of Godard and Bertolucci (Detroit: Wayne State University Press, 1995), 95.

${ }^{60}$ Charles Warren, "Whim, God and the Screen." In Jean-Luc Godard's Hail Mary: Women and the Sacred in Film, edited by Maryel Locke and Charles Warren (Carbondale: Southern Illinois University Press, 1993), 10.
} 
Miéville, which was "fundamentally secular" and contains no religious references or imagery at all. ${ }^{61}$ While The Last Temptation of Christ would perhaps on the surface offer more grounds for complaint as it deals with religious themes in a far more overt manner than Hail Mary, there was a similar distinction between the "imagined" film of the complaints made, largely based on reports from overseas, and the film as assessed by the Chief Censor, as Everard determined that the "denigration" of which complainants had written was not in fact present in the film at all, so could not be taken into account.

Although Hail Mary was submitted to the Chief Censor for classification for screenings in a film festival context, Arthur Everard took no special consideration of this intended viewing context when classifying the film. This was consistent with Everard's other decisions during his tenure as Chief Censor, although it differed to some extent from the approach taken during Tunnicliffe's era, where the daybook notes sometime contain suggestions that films may be appropriate for certain audiences but not others, such as restricting films to film societies or film festival audiences.

Arthur Everard's use of third party authorities as a means of rationalising censorship decisions, in this case through consultation with members of the general public at a screening of Hail Mary, was very much secondary to his own assessment of the content of the film, and was ultimately not a significant factor in the decision which he made. In the case of The Last Temptation of Christ, there does not appear to have been any formal consultation despite the Hail Mary court case. However, this did not cause any legal problems with the decision to pass the film uncut, and the decision was rationalised in the same way as that for Hail Mary, as a result of the lack of any material which was seen to denigrate Christians or Christianity. In neither case did Everard make any appeal to academic research to justify his decisions as he had done in the past, perhaps due to this perceived lack of genuinely contentious material.

The way in which the views of lobby groups factored into the Chief Censor's decisionmaking process in the case of Hail Mary and The Last Temptation of Christ was largely consistent with the way in which he had gone about the classification of other controversial films, with views on the films that were seen as ill-informed and not firmly based on the actual content of the film not given discursive legitimacy. Neither the

61 Sterritt, 70. 
censors nor government ministers felt that the complaints about the films warranted any additional action.

\section{Censorship by the Video Recordings Authority, 1987-1990 - historical narrative}

The Video Recordings Act came into force on 1 July 1987, and the new Video Recordings Authority was headed by former film censor Ainslie Witaszek, who had also worked in "various positions within the Internal Affairs Department". ${ }^{62}$ While the legislation was significantly more moderate than the British Video Recordings Act of 1984, and New Zealand had been spared the kind of hysteria over "video nasties" that had occurred in the UK, the Video Recordings Authority appeared to take a much stricter stance on contentious material than the Chief Censor's Office under Arthur Everard. Many videos were not viewed by the VRA as they were given advisory classifications by the Video Labelling Body based on ratings given to the films by the Chief Censor, but when videos did come before the VRA, they seemed to take a stricter approach than the film censors. In fact, during the period from the start of formal video censorship under the VRA until the end of Everard's tenure as Chief Censor, some films were in the anomalous position of having been banned on video for private viewing by the VRA, but passed uncut on video by the Chief Censor, nominally for public exhibition. This situation was highlighted by Raybon Kan, at the time a postgraduate law student, in a paper entitled "Video Censorship and 'Denigration"', where he suggested that the Chief Censor had "been less restrictive" than the VRA, "although their respective Acts share very similar decision-making criteria". ${ }^{63}$ These films included Wes Craven's The Last House on the Left and the prison-set exploitation film Penitentiary III, both given uncut R16 certificates by Everard, as well as a number of pornographic films granted an R18 certificate. The Last House on the Left was viewed by Everard alone ${ }^{64}$, and Penitentiary III was viewed by all three

\footnotetext{
${ }^{62}$ Chris Watson and Roy Shuker, In the Public Good? Censorship in New Zealand (Palmerston North: The Dunmore Press, 1998), 71.

${ }^{63}$ AAAC 7536 W5169 Box 9 - Video Recordings Board of Review Meetings - Angel of Vengeance 1988-1990.

${ }^{64}$ ADNB 23133 W5730 Box 232 - Daybooks of Chief Censor of Films - 21/4/87 to 19/1/88.
} 
censors with daybook notes taken by Deputy Chief Censor Susan Cooke. ${ }^{65}$ In neither case do the daybook notes indicate that there was any consideration of possible cuts, or any consideration of potentially banning the film - the notes simply describe the content of each film. All of these films were submitted to the Chief Censor for classification after they had been rejected by the Video Recordings Authority, except for The Last House on the Left, which was classified on 8 June 1987, before the Video Recordings Authority had come into operation. ${ }^{66}$ This situation also received some press coverage, with The Dominion noting in 1988 that the two censorship bodies had been "at odds" and that new Minister of Internal Affairs Michael Bassett had "called for an inquiry" into the matter. ${ }^{67}$ Another article identified several of the pornographic films banned by the VRA but passed by the Chief Censor, as well as Penitentiary III, with Ainslie Witaszek of the VRA asked about the reasoning for banning the video Heavenly Desires, and Arthur Everard asked why he had passed it:

The Dominion asked Mr Everard and Ms Witaszek for explanations of their decisions on Heavenly Desires - an American-made video about two female ghosts who are promised by the devil eternal pleasure if they can get two first-year college students to lose their virginity.

Ms Witaszek said the authority banned the video because it reinforced the belief held by some people that virginity must be lost and the sooner the better.

Those who did not hold that belief were frequently victims of coercion, harassment and loss of choice over keeping their virginity, she said.

Mr Everard described Heavenly Desires as an ordinary straight sex film.

He said his staff did not take any notes on the video when they examined it as it did not stand out from any of the others submitted. Consequently it was given an R18 certificate with a censor's warning of explicit sexual content, normal for movies of its type. ${ }^{68}$

An interview with Witaszek the following year provides a more general insight into the way the VRA made its decisions, with Witaszek explaining that the Authority had been

\footnotetext{
65 ADNB 23133 W5730 Box 235 - Daybooks of Chief Censor of Films - 12/2/88 to 3/10/88.

${ }^{66}$ ADNB 24958 W5848 Box 30 - Register of Classification Decisions 1987-1988.

67 The Dominion, 22 November 1988.

68 Dominion Sunday Times, 2 October 1988. The article is inaccurate in stating that no notes were taken on the film, as Everard himself did take some notes (ADNB W5730 23133 Box 236 - Daybooks of Chief Censor of Films - 7/4/88 to 11/11/88), but these were brief and indicated that it was the same video that had already been passed the previous year by Deputy Chief Censor Anthony Hill, who had taken more detailed notes (ADNB W5730 23133 Box 228 - Daybooks of Chief Censor of Films $30 / 10 / 86$ to $15 / 4 / 87)$.
} 
on "a voyage of discovery" as they were operating under new legislation without the established procedures that the Chief Censors Office had, but that like the Chief Censor, they did not have "what is often referred to as a shopping list or a grocery list" of material that required banning or restricting and that context was a key factor. ${ }^{69} \mathrm{An}$ article written by Libby Hogg, one of seven temporary examiners during this early period, also emphasised that the VRA did not "operate a "shopping list" approach", and that "[e]ach video is examined and left to stand or fall on its own merit", and that while the media had sometimes "focused on the possibilities of "copycat crime", the video censors did not "operate from this basis". ${ }^{70}$

While these articles provide some limited insight into the rationale behind the decisions of the VRA in their early years of operation, during the period from 1987 to 1990 , this reasoning was not always clear, as the VRA did not keep daybooks in the same manner as the Chief Censor, and they would not start publishing detailed reasons for their decisions until 1991. For example, the ban on The Last House on the Left was announced simply by a notice that the film had been classified as "indecent" under Section 23 of the Video Recordings Act, although such notices were sometimes slightly more informative, as in the case of Fresh Kill, which was banned "owing to its depiction of matters of CRIME AND VIOLENCE in a manner that is injurious to the public good. ${ }^{71}$ However, in the case of the films Fresh Kill, Penitentiary III and Angel of Vengeance ${ }^{72}$, all of which had their bans by the Video Recordings Authority appealed by their distributors, the records of the Video Recordings Board of Review provide further information on the rationale behind the VRA's original bans. VRA examiner Stephanie Miller's notes on Penitentiary III explain that the justification for banning the film included the "real danger in the possible inability of some viewers to differentiate between the exploitation of the film's antisocial content and reality". ${ }^{73}$ The film's perceived lack of realism and its highly stylised nature were also seen in a negative light, with Miller arguing that the way in which the film was shot "softened the atmosphere and obliterated harsh prison detail", thus providing a "distorted depiction

\footnotetext{
69 Preview, February 1989, 20.

70 Illusions, 10 March 1989, 29-30.

${ }^{71}$ ADNB 23134 Box 284 - Video Recordings Authority Classification and Excision Notices 1988.

72 This was a film from 1987 also known as War Cat, not the Abel Ferrara film Ms. 45 which is also known as Angel of Vengeance.

${ }^{73}$ AAAC 7536 W5169 Box 9 - Video Recordings Board of Review Meetings - Penitentiary III 19881990.
} 
of prison conditions". ${ }^{74}$ The way in which the violence was portrayed was seen as giving it "a sense of status, an aura of glamour", and the impact of the violence was "not depicted honestly", in that the film "took little account of the amount of violent punishment the human body is capable of sustaining". ${ }^{75}$ Fresh Kill was described in an unsigned "Reason for rejection" as having a "shallow and exploitative format [which] suggested that crime and violence are upbeat activities", and that it "had the effect of trivialising violence and antisocial behaviour". ${ }^{76}$ The film was directly contrasted with another film which had been passed by the VRA, with the argument that this film's lack of moral ambiguity allowed it to be passed by the Authority:

A useful comparison could perhaps be made with DANCE OR DIE which was submitted in the same batch of videos and examined around the same time.

Like FRESH KILL, the video entitled DANCE OR DIE, was a violent drug related drama.

Unlike FRESH KILL it was an imaginatively conceived and tightly directed film with an ably constructed story line.

Of significant difference was the overall treatment of antisocial behaviour. Specifically, alcoholism and drug dependency were depicted in a believable context of awareness, remittance, and therapy, and drug taking was shown to be non glamorous and undesirable. There were, in essence, no double messages in DANCE OR DIE. ${ }^{77}$

Like Penitentiary III, Angel of Vengeance also had a detailed explanation of its ban written up by Stephanie Miller. Concern was expressed over the perceived "blatant disregard for human life", as well as the fact that it allegedly "feeds off a sub theme of sexual violence". ${ }^{78}$ While it was argued that "[s]ubtle devices are used in a ploy to suggest negation" of a "negative group (gang) male psychology regarding women", as in the case of Fresh Kill, the perceived ambiguity was seen as problematic, Miller arguing that she was "concerned that viewers of gang/group mentality and immature perspective will not be alerted to such subtleties and will have injurious attitudes

\footnotetext{
74 Ibid.

75 Ibid.

${ }^{76}$ AAAC 7536 W5169 Box 9 - Video Recordings Board of Review Meetings - Fresh Kill 1988-1990.

77 Ibid.

${ }^{78}$ AAAC 7536 W5169 Box 9 - Video Recordings Board of Review Meetings - Angel of Vengeance 1988-1990.
} 
reinforced by this film".$^{79}$ Miller also made a rather extraordinary comment regarding the film's perceived lack of artistic merit:

Exposure to poorly filmed, acted and scripted video films such as this (which exploit excesses of antisocial - violent - behaviour) will surely lower society's sense of film making and artisitic [sic] appreciation and result in an increasing acceptance of mindless violence in society. 80

While the VRA did not provide reasons for most of their decisions in the first few years of their existence, another way in which insight into their decision-making process can be gained is in the case of films where the VRA required cuts to be made to a film before it could be granted a classification, as they did provide information on the reasons for such cuts. Pornographic films tended to be the most heavily cut videos, usually for sexual violence or coercive sex. Cutting such films for these reasons was in line with what the Chief Censor's Office was also doing. For example, Deputy Chief Censor Sarah Ingram banned outright a video entitled Tailenders as it "could not be cut to [an] acceptable level" due to an "overwhelming tone of sexual violence", Ingram describing it as the "[n]astiest tape l've seen in ages". ${ }^{81}$ In contrast, Everard passed uncut a video entitled Hard Choices, his daybook notes indicating that it portrayed "absolutely straightforward sex; no hints even of violence, coercion, incest, etc etc". ${ }^{82}$ In 1989, Ainslie Witazsek of the VRA wrote that she believed that "for several years the Chief Censor's Office has been using 1 censor to examine explicit sex videos, and the film censors have been viewing these videos on fast forward". ${ }^{83}$ The daybook notes from this period suggest that while it was true that generally only one censor would view each individual video, it was highly unlikely that the latter claim was true, as pornographic videos tended to have daybook notes which were as extensive and detailed as any other films examined by the Chief Censor's Office at this time.

In the case of the VRA, sometimes the cuts made to pornographic videos were not for just sexual content - for example, the video Hot Cars Nasty Women required a cut to "[d]elete mockery of presumed handicap" ${ }^{84}$, Miami Spice needed excisions to "reduce

\footnotetext{
79 lbid.

80 Ibid.

${ }^{81}$ ADNB 23133 W5730 Box 228 - Daybooks of Chief Censor of Films - 30/10/86 to 15/4/87.

${ }^{82}$ ADNB 23133 W5730 Box 240 - Daybooks of Chief Censor of Films - 31/10/88 to 20/07/89.

${ }^{83}$ ADNB 23137 Box 4 - Video Industry AVANZ 1988-1989.

${ }^{84}$ ADNB 23134 Box 282 - Video Recordings Authority Classification and Excision Notices 1987-1988.
} 
trivialisation of drug taking" and "drug dealing"85, and Hot Talk Radio required cuts to eliminate dialogue "which denigrates lesbians/gym teachers, mongoloids and members of Women Against Pornography as classes of people". ${ }^{86}$ While such cutting continued throughout the VRA's existence, it was only in their first couple of years that they also routinely cut mainstream non-pornographic films, sometimes for sexual violence, but also for a variety of other reasons. Graphic but non-sexual violence was one target, with the film Dream Maniac (1986) cut to "[s]ubstantially reduce first drill sequence" and "Remove throat-slitting sequence"87, and Circleman (1987) cut to "reduce depiction of violence at unrealistic level (i.e. beyond that normally sustainable by human body". ${ }^{88}$ Potentially imitable construction of makeshift weapons was another concern, with Hard Ticket to Hawaii (1987) cut to remove "'preparation of weapons and insertion of blade in frisbee" 89 , while Open House (1987) suffered cuts to "remove explicit depiction of assembly of razor blade weapon". ${ }^{90}$ Some of the required excisions seem to defy categorisation, as in the case of the horror film Death Mask (1988):

Delete sequence in which graphic murder and mutilation are depicted in association with heavy metal music performance (graphic depiction and glamorization of bizarre violence) ${ }^{91}$

Violence against women was also a concern of the Board, even when not clearly sexualised. Deranged was cut to reduce a "gratuitous, prolonged and explicit" attack on a pregnant woman, while Herschell Gordon Lewis's low-budget gore film The Gore Gore Girls (1972) required several excisions to "substantially reduce the violence with which women are murdered". ${ }^{92}$ This film came to the attention of the VRA again in 1991, when a member of the public wrote to complain that the video cover had proclaimed it to be the uncut version of the film, when it was not. Lois Hutchinson replied that the VRA had no control over video covers, and while the correspondent had stressed the obvious fakeness of the special effects in the film, which used mannequins, as a mitigating factor, Hutchinson argued that this was not relevant:

\footnotetext{
${ }^{85}$ ADNB 23134 Box 283 - Video Recordings Authority Classification and Excision Notices 1988.

${ }^{86}$ ADNB 23134 Box 290 - Video Recordings Authority Classification and Excision Notices 1990.

${ }^{87}$ ADNB 23134 Box 282 - Video Recordings Authority Classification and Excision Notices 1987-1988.

${ }^{88}$ ADNB 23134 Box 283 - Video Recordings Authority Classification and Excision Notices 1988.

${ }^{89}$ ADNB 23134 Box 282 - Video Recordings Authority Classification and Excision Notices 1987-1988.

90 ADNB 23134 Box 283 - Video Recordings Authority Classification and Excision Notices 1988.

91 ADNB 23134 Box 284 - Video Recordings Authority Classification and Excision Notices 1988.

${ }^{92}$ ADNB 23134 Box 282 - Video Recordings Authority Classification and Excision Notices 1987-1988.
} 
I believe it was in the censor's mind to lessen the impact of the video because it put such a heavy emphasis on the butchery of women. It is of little importance whether or not the "woman" butchered is a mannequin or real. The point is it shows a depiction of a treatment of what is identified as a woman. ${ }^{93}$

One common feature of video tapes was the presence of trailers before the main feature, and due to the fact that they often tended to show a selection of violent highlights from a film, they also became a target for the VRA's excisions. For example, the film Death by Dialogue (1988) required no cuts, but the two trailers that preceded it needed to be removed, both with the explanation that they presented "concentrated and casual depiction of violence out of context", as they were separated from the film as a whole. ${ }^{94}$ Similarly, Dance or Die needed its two preceding trailers removed for "concentrated depiction of anti-social behaviour and sustained, graphic violence" and "sustained depiction of graphic and brutal violence". ${ }^{95}$ Such a concern over material taken out of context suggests a somewhat similar rationale to that of the Chief Censor in banning the video nasties compilation tape.

\section{Censorship by the Video Recordings Authority, 1987-1990 - analysis}

The decision-making process of the Video Recordings Authority in its first few years of operation is not as transparent as that of the film censor's office at the same time. There is not a great deal of information for the period 1987-1990, as the VRA did not keep daybooks and there were no detailed written decisions published until 1991. Also, there were no significantly controversial individual cases that put the VRA in the position of justifying and explaining their decisions in the way that had been occurring in the case of the Chief Censor's office.

However, based on the information in the records of several films which went to the Video Recordings Board of Review, and the explanation of excisions made to some videos, it is possible to make some conclusions about the way in which the VRA's decisions were rationalised during 1987 to 1990 . It is evident that the VRA was clearly

\footnotetext{
${ }^{93}$ ADNB 23137 Box 4 - Video Classification/Interest Groups - National Council of Women 1986-1991.

${ }^{94}$ ADNB 23134 Box 284 - Video Recordings Authority Classification and Excision Notices 1988.

95 Ibid.
} 
stricter in some cases than the Chief Censor as some films banned by the VRA were passed by the Chief Censor, even though the Video Recordings Act was set up on the foundation of less strict censorship for video than for public exhibition. Key issues in their decisions appear to be the perceived realism (or otherwise) of film, the imagined audience, and subjective value judgments on the quality of the films - for example, Penitentiary III was seen as giving a "distorted view of prison conditions" due to its stylisation and lack of realistic violence, and that this could negatively affect "impressionable" young people. Another significant issue which was identified was ambiguity in a film's message - for example, Fresh Kill was banned partly because it contained "double messages" about crime and drugs that a similar film, Dance or Die, did not. Censorship often involves a degree of "fixing" a meaning on a film in order to make a judgement on a classification, and in this case it seems that the VRA was potentially taking a simplistic path when they were unable to establish a clear, unambiguous message which could be encapsulated in a censorship classification.

Particularly in the various rationales for making excisions to videos, the Video Recordings Authority seems to lack the consistency and coherence of decisionmaking that the Chief Censor's office had. This was perhaps a result of the lack of institutional continuity which the film censors had had for many years, demonstrating B. Guy Peters' point that "structures persist while individual members of those structures come and go", and that "structures (institutions) create more regularity of human behaviour than would otherwise exist". ${ }^{96}$ There is certainly evidence of a lack of the "regularity of human behaviour" demonstrated by the Chief Censor's office in the decisions of the VRA - for example, the idea of basing decisions on potential "copycat crime" was explicitly rejected by one of the video censors, but some of the excisions made to films were in fact made on this basis. VRA head Ainslie Witaszek's acknowledgement of these early years of formal video censorship as a "voyage of discovery" seems to be a direct acknowledgement of the difficulty of working in a consistent and clear manner in a newly established censorship institution, and in the VRA's remaining years until finally disestablished in 1994, its decisions became more clear and consistent, and there was much less heavy use of excisions for mainstream non-pornographic videos.

${ }^{96}$ B. Guy Peters, "Institutional theory: problems and prospects." In Debating institutionalism, edited by Jon Pierre, B. Guy Peters and Gerry Stoker (Manchester: Manchester University Press, 2008), 6. 
The other new censorship body set up by the Video Recordings Act was the Video Recordings Board of Review, which was to deal with appeals against decisions made by the Video Recordings Authority - thus, they only dealt with films that had already been examined by that body. Some of their rationalisation of their decisions, such as concerns over lack of realism in portrayals of violence and potential mixed messages, were very similar to those of the Video Recordings Authority, but the more detailed archival records of their operations reveal a number of other factors in their decisionmaking process.

\section{Censorship by the Video Recordings Board of Review, 1987-1990 - historical narrative}

During its existence from the inception of the Video Recordings Act to the Films, Videos and Publications Classification Act coming into force, a period from 1987 to 1994, the Video Recordings Board of Review examined eleven videos. Of these, all but two were examined under from chairperson Brenda Cutress, a Wellington lawyer ${ }^{97}$, between 1988 and 1990, with the final two examined under new chairperson Dr Hillary Lapsley in late 1990 and 1991. After this, the Board was inactive until it was abolished by the new legislation. All but three of the videos examined were sexually explicit pornographic tapes. The videos examined by the Board of Review fall broadly into three categories: films banned by the Video Recordings Authority (comprising one pornographic video and the three non-pornographic films) which had their bans appealed by their distributors; pornographic videos that had been submitted to the VRA by the SPCS, passed with R18 certificates, and then submitted to the Board of Review by the SPCS; and other pornographic videos which the SPCS requested be forwarded to the Board of Review but which had not originally been submitted to the VRA by them. The second and third categories comprise seven of the eleven total videos, so over half of the videos examined by the Board were at the direct request of the SPCS. Unlike the Video Recordings Authority, the Board of Review provided detailed written explanations of each decision they made, published in the New

${ }^{97}$ Evening Post, 15 August 1989. 
Zealand Gazette, and these as well as notes of their meetings provide a significant insight into their rationale and decision-making process.

The first category includes the films Penitentiary III, Angel of Vengeance and Fresh Kill, all non-pornographic, low budget American exploitation films. Penitentiary III and Angel of Vengeance had their bans upheld, while Fresh Kill was passed uncut with an R18 certificate. In the case of Penitentiary III, the Board of Review shared the VRA's concern over the film's lack of realism, their formal written decision describing the film as having "a totally dishonest depiction of prison life", as well as the fact that the violence "should have resulted in death or grievous bodily harm", yet "caused little or no longstanding harm to the principle characters". ${ }^{98}$ The Board also felt the ambiguity of the film was problematic, that despite the "purported message" that "good triumphs over evil", the presence of "antisocial themes" as well as this meant that it "could confuse its target audience of young males, particularly if they are immature and unsophisticated". ${ }^{99}$ The Board also singled out one element which was not highlighted by the VRA, the fact that " $[$ t]he depiction of a dwarf is distasteful and could offend little people". 100 The meeting notes, which were not made publicly available at the time, are even more candid, with one member of the board stating "'do we need any more of this ilk - Indecent category", as well as stating that in the case of the dwarf character "[p]eople feel uneasy with little people - This reinforces [the] whole thing". ${ }^{101}$ Another Board member stressed the significance of the video format, that the viewer "can manipulate videos, can speed up - slow - play over and over". ${ }^{102}$ Notes taken of a telephone conference suggest that the Board had an extremely strong reaction to the film:

There was a need to say that this was not just a nasty but unimportant video. It was seriously degrading. To say it could offend was not strong enough. ${ }^{103}$

In the case of Angel of Vengeance, the Board believed that the film's "[u]nremitting and frequently gratuitous violence shown after the first 23 minutes and the total lack

\footnotetext{
98 AAAC 7536 W5169 Box 9 - Video Recordings Board of Review Meetings - Penitentiary III 19881990.

$99 \mathrm{lbid}$.

100 lbid.

101 lbid.

102 lbid.

103 Ibid.
} 
of respect for life" made it worse than other videos that were available, and thus warranting a ban, with one Board member's comment in the meeting notes explicitly placing the Board members "above" the film's potential audience, asking "would they see it at level we do"? ${ }^{104}$ While it was the one film of the three to be passed by the Board, Fresh Kill made this perspective even clearer. The official decision argued that an R18 rating was justified as the nature of the violence "would be injurious to the young audience to whom the video is principally directed" but that older viewers "would see it as an implausible trite story". ${ }^{105}$ In the meeting notes, one examiner argued that the Board was "looking at it [as] a sophisticated and educated adult" rather than as a "young person" would, while another explained that "[w]e all agree about this film. It's trite, should it be indecent", and that "I can't believe a sophisticated adult would want to watch it", as well as concluding the meeting with an explanation for the R18 classification:

I hope that people over 18 would realise that it was trite silly nonsense. I would be concerned about 15 and 16 year olds seeing it who are not too bright. ${ }^{106}$

Aside from these three films, all videos examined by the Board of Review were sexually explicit pornography. The Society for the Promotion of Community Standards had submitted a number of pornographic videos to the Video Recordings Authority, including the two videos that had been subject to a court case, Pretty as You Feel and Inches. The VRA requested several cuts to Pretty as You Feel, and since the SPCS was considered the "owner" of the video as they had submitted it for classification, they "refused to agree to the proposed excisions", and it was banned outright. ${ }^{107}$ However, Inches, as well as two other videos, were passed R18 uncut, so the Society appealed the decisions and had them re-examined by the Board of Review. One of these videos, Hot Rackets, provides particular insight into the way the Board worked, and their sometimes unusual interpretations of what constituted "injurious to the public good". The Board required that one scene be cut for an R18 certificate, which was described in the official written decision as "extremely cruel", in which a blind man receives oral sex from a woman culminating in him declaring "I can see". The Board

\footnotetext{
104 AAAC 7536 W5169 Box 9 - Video Recordings Board of Review Meetings - Angel of Vengeance 1988-1990.

${ }^{105}$ AAAC 7536 W5169 Box 9 - Video Recordings Board of Review Meetings - Fresh Kill.

106 lbid.

107 ADNB 23134 Box 283 - Video Recordings Authority Classification and Excision Notices 1988.
} 
argued that this "cruel mockery of a person's disability in this manner" was "beyond merely tasteless", but was in fact "indecent", although giving no further explanation as to why it should be considered "indecent". ${ }^{108}$ As in the case of films such as Fresh Kill, the Board members' subjective value judgments about this video are strongly evident in the notes of their meeting - it was described variously as "so bad it was silly", "unintentionally funny", "cheap, junky and trashy" and "too silly to ban". ${ }^{109}$ However, the sequence involving the blind man was singled out by multiple Board members, one member being "bothered by the blind bit" and "always bothered by anyone depicted disabled". ${ }^{110}$ Since it was the SPCS who had originally submitted the video, they refused to make the required cuts, the VRA's R18 classification was overturned, and the video was banned. ${ }^{111}$

The third category of videos were not originally submitted to the VRA by the SPCS, but re-examined by the Board of Review at the request of the Society. In 1990, the SPCS requested that the Secretary of Internal Affairs submit four videos to the Board. In a letter to Patricia Bartlett, Minister of Internal Affairs Margaret Austin explained that two of the videos had not been forwarded to the Board for re-examination as "the contents of these videos did not differ significantly from many other videos rated R18 which are already available to the public", but that the other two were forwarded not because of the existing legislation, but on the basis of recommendations of the Committee of Inquiry into Pornography that had not yet come into force:

I am advised that the Secretary referred Colour Climax Program 331 to the Board on the basis that its subject matter (urination) fell into the category of material which the Committee of Inquiry into Pornography recommended should be presumed to be indecent. Pain by Lana was referred to the Board on the basis that it might also fall into this category, insofar as bondage and discipline could arguably be interpreted as force, coercion or violence in a sexual context. ${ }^{112}$

Both videos had their R18 classifications overturned by the Board of Review in favour of outright bans, with no recommendations for potential excisions. In both cases, the Board appeared to go beyond the requirements of the censorship legislation itself and

\footnotetext{
108 AAAC 7536 W5169 Box 9 - Video Recordings Board of Review Meetings - Hot Rackets 19881990.

109 Ibid.

110 lbid.

111 lbid.

112 AAAC 7536 W5169 Box 5 - Videos for Private Viewing - Ministerial Correspondence 1989-1991.
} 
into the realm of subjective value judgements. In the case of Colour Climax Program 331, the Board even explicitly stated this, arguing:

In addition to the statutory requirements which the Board considered it also noted the false impressions that can be created by videos of this type to persons inexperienced in sexual activity. The fact that the scenes were portrayed in a light-hearted manner as though urination was a normal and enjoyable part of sexual activity was disquieting. ${ }^{113}$

In their decision on Pain By Lana, the Board argued that "the association of such extreme cruelty with a pleasurable activity constitutes offensive behaviour", and the consensual nature of the material was not relevant:

As already noted the Board recognises that some men choose to be subjected to bondage and discipline sessions in order to obtain sexual satisfaction. Nevertheless it is an aberrant behaviour. The Board questions the desirability of producing commercial videos of such behaviour for entertainment purposes. ${ }^{114}$

Such a tendency to rely on overtly subjective value judgements, rather than the more measured carefully rationalised decisions of the film censors, was a significant element of the decisions of the VRBOR during its few years of operations.

\section{Censorship by the Video Recordings Board of Review, 1987-1990 - analysis}

Although the Video Recordings Board of Review was not disestablished until the 1993 Films, Videos and Publications Classification Act came into force, most of their activity occurred in the first few years of their existence, with only a couple of pornographic videos examined after 1990. However, unlike the Video Recordings Authority, there are very detailed records in Archives New Zealand that shed a light on their decisionmaking process and the rationale for their decisions. One of the most interesting aspects of the workings of the Video Recordings Board of Review is the general lack of any explicit reference to the home video viewing context in either their meeting notes or their official decisions. Writing in 2013, Caetlin Benson-Allott argues that "many contemporary spectatorship theorists fail to address the video revolution at all" and "[a]Imost all recent work on motion picture spectatorship continues to posit film as the

${ }_{113}$ ADNB 23137 Box 4 - Video Classification - Board of Review List of Decisions 1988-1993. 114 Ibid. 
movies' natural medium and cinemas its province"115, so it would have been highly unlikely for a newly formed body such as the VRBOR, in the early years of home video, to have a clear conception of the nature of video spectatorship in relation to their work in censoring videos. Benson-Allott describes her conception of video spectatorship in the following manner:

Whereas cinema and television immerse the spectator in the illusion of voyeurism or indulge her in narcissistic fantasies of panoptical vision, the prerecorded video apparatus replaces such powers with temporal control. That is, all video playback technologies give their subjects (limited) temporal control over the motion picture and sustain the subject's fantasy of coherence and autonomy through an illusion of temporal mastery. ${ }^{116}$

While such "temporal mastery" was one of the concerns during the "video nasties" scare in the United Kingdom, the only direct reference to it in the archival evidence is one Board member's reference to being able to "manipulate videos" and "play over and over" particular scenes. However, there was some attempt to address the nature of home video viewing in the way in which the VRBOR constructed an imagined audience of "impressionable" younger viewers who were considered likely to be negatively affected by certain material. Chief Censor Arthur Everard generally did not overtly construct an imagined audience in making his decisions, and even in the case of the compilation of material from "video nasties" intended to be viewed by members of parliament, simply treated the plan to show this material as a standard public exhibition with no special circumstances. However, the VRBOR was explicitly concerned with certain audiences, particularly young people, and the way in which they might be susceptible to the videos in a way in which the VRBOR members, and other viewers perceived as more intelligent and sophisticated, would not. This is even more pronounced in the meeting notes than in the formal written decisions, reflecting Sara E. Shaw's idea that "[d]iscourse is made up of groups of statements that present a particular reality of the world" - the internal discourse of the Board reflect a more candid attitude to the films they were classifying and the audiences which they believed would be viewing them than their official written decisions. ${ }^{117}$ Such a

\footnotetext{
115 Caetlin Benson-Allott, Killer Tapes and Shattered Screens: Video Spectatorship from VHS to File Sharing (Berkeley: University of California Press, 2013), 7.

${ }^{116}$ Benson-Allott, 204.

117 Sara E. Shaw, "Reaching the parts that other theories and methods can't reach: How and why a policy-as-discourse approach can inform health-related policy," Health 14, no. 2 (2010): 204.
} 
distinction between public and private discourses of censorship is also evident when comparing the Chief Censor's "in-house" material such as daybooks and informal file notes with official correspondence.

While judgements about the artistic merit or otherwise of films did not significantly factor into the decisions of Chief Censor Arthur Everard, the Video Recordings Board of Review took a very different approach. The perceived lack of quality of some videos appeared to factor into their decisions, with very clear negative value judgements about the films which they were assessing. The Video Recordings Board of Review also deviated from the established practice of the Chief Censor in determining the difference between what could genuinely be seen as "injurious to the public good" and what was merely "offensive". There was an apparent conflation of the two concepts rather than a clear division, with the VRBOR tending to assume that a sufficient degree of offensiveness could in itself be considered injurious - for example, in the case of Penitentiary III, one member suggested that "[t]o say it could offend was not strong enough", while in their official decision the Board argued that Hot Rackets went "beyond merely tasteless", although in neither case fully explaining how either video was genuinely "injurious".

Like the Video Recordings Authority, the issues of perceived realism of films on video and their overall tone were concerns of the Video Recordings Board of Review. Lack of realism was seen as potentially making films more liable to be "injurious", and glamourising violence, while the fact that the films were perceived as not unambiguously condemning the violent and antisocial material which they presented was seen as ground to justify a ban - for example, Penitentiary III could potentially "confuse" "immature and unsophisticated" young viewers. Somewhat ironically, the VRBOR's own decision-making rationalisations were not without their own ambiguity, and tended to involve a significant use of contentious and unclearly defined language, which was much less evident in the contemporary decisions of the Chief Censor or even the Video Recordings Authority. Arthur Everard explained in retrospect that "it wasn't our job to be moral guardians" but to focus on what was considered likely to harm rather than what was allegedly "immoral", and the archival evidence suggests that this position was adhered to by both film censors and government ministers. ${ }^{118}$

118 Interview with Arthur Everard. 
However, the VRBOR made judgements clearly based on a belief that they had a role as "moral guardians", describing the video Pain By Lana as presenting "offensive behaviour" which was also "aberrant" and not viewed as desirable to be presented as entertainment. The portrayal of a dwarf character in Penitentiary III as "distasteful" demonstrated a similarly subjective value judgement, something which Raybon Kan argued in his paper "is obviously a statement of taste rather than a consideration of whether something will injure the public good". ${ }^{119}$ The Board's use of the term "gratuitous" to describe the violence in Angel of Vengeance was similarly highlighted by Kan as also "a statement of taste" and that for some viewers it may be "just the right amount of violence". ${ }^{120}$

\section{Chapter summary}

The latter half of Arthur Everard's tenure as Chief Censor was marked by the return of religion as a controversial factor in cinema censorship, and two significant court cases. However, Everard's decision-making process was consistent with the cases of films such as I Spit on Your Grave and The Driller Killer, which were controversial for rather different reasons, with an emphasis on carefully considered classifications which were rationalised in a manner that generally avoided overtly subjective and emotive language, and did not give credence to complaints and protests which were not based on genuine first-hand knowledge of the films in question. However, the newly formed Video Recordings Authority and Video Recordings Board of Review operated rather differently, with both censorship bodies identifying an imagined audience of vulnerable and impressionable young people who needed to be protected from the perceived excesses of home video, perceived excesses which were described with overtly subjective and pejorative language, and which were also seen as not having any such effect on the more "sophisticated" censors who were assessing the films. The remaining years of the separate film and video censorship until the Films, Videos and Publications Act came into force in 1994, saw a new female Chief Censor, Jane

\footnotetext{
${ }^{119}$ AAAC 7536 W5169 Box 9 - Video Recordings Board of Review Meetings - Angel of Vengeance 1988-1990.

120 lbid.
} 
Wrightson, more transparent and consistent decision-making by the VRA, and the almost complete absence of videos being referred to the VRBOR. 


\section{Chapter Six: Chief Censor Jane Wrightson, 1990-1994}

\section{Chapter overview}

This chapter covers the period from 1990 to 1994, encompassing the end of Arthur Everard's tenure as Chief Censor and the three years from 1991 to 1994 which Jane Wrightson spent as Chief Censor. This period also saw the election of a new National Government in 1990, and the passage of the Films, Videos and Publication Act 1993, which came into force on 1 October 1994. This Act combined censorship of films, videos, and other publications such as books and magazines under one single piece of legislation and one official body, the Office of Film and Literature Classification. The two major case studies of film censorship examined in this chapter are John McNaughton's Henry: Portrait of a Serial Killer and Pier Paolo Pasolini's Salò, or the 120 Days of Sodom, both of which were banned from public exhibition by the Chief Censor. Both these films have elicited extremely polarised reactions ever since their original releases, as they "straddle both the art film and the exploitation sphere", and their extreme content tends to be seen as either gratuitous and unnecessary, or essential to the films' themes and ideas. ${ }^{1}$ In both cases, the "art or exploitation?" debate was a significant part of the discourse around the censorship of the films, and demonstrates the importance of contextual factors outside a film's manifest content in the censorship process. As Simon Hobbs notes, film texts are "rarely presented in an unaccompanied state", and the way they are presented, including advertising, public discourse, and the viewing context, affects their reception. ${ }^{2}$ Both films have also been extensively written about in relation to controversy and censorship in other countries, and this chapter adds a New Zealand perspective to this wider body of scholarship.

\footnotetext{
${ }^{1}$ Simon Hobbs, "Salò, or the 120 Days of Sodom: The Contemporary Distribution of Sexual Extremity," Cine-Excess.

2 Hobbs.
} 
As well as these examples of film censorship, this chapter looks at the operation of the Video Recordings Authority from 1990 to 1994, when its decision-making process became more transparent as it began to publish detailed written explanations of its classification decisions. The discussions of the operations of the Chief Censor's Office and the VRA in this period highlight a number of important themes, including the significance of factors such as artistic merit and perceived realism in censorship decision-making, the role of the imagined audience, the significance of the perceived tone of films rather than purely their manifest content, and the issue of discursive legitimation and which voices and viewpoints were given greatest significance in contentious censorship decisions. This chapter also highlights continuing significant differences between cinema censorship and video censorship in New Zealand before both were brought together under one piece of legislation, as well as highlighting the concept of censorship as a process involving a competition for power, influence and discursive legitimacy.

\section{A period of transition}

The last Minister of Internal Affairs in the 1984 to 1990 Labour Government was Margaret Austin, who held the position briefly in 1990. While she does appear to have expressed some views suggesting a desire for stricter censorship, expressing her concerns in response to one correspondent about "undesirable videos" being available $^{3}$, she also appears to have taken a very similar official line to her predecessors Michael Bassett and Peter Tapsell. For example, on the issue of media effects, she noted in one letter that there are "conflicting results" of media effects research but "many thousands of people" are unaffected by "pornographic and violent material", although "persons predisposed" may be affected. ${ }^{4}$ She also stressed that on the issue of film and video censorship, the government was "acting in response to the wishes expressed by New Zealand citizens" and that they had "selected a middle course which is acceptable to the majority of people". ${ }^{5}$

\footnotetext{
${ }^{3}$ AAAC 7536 W5169 Box 5 - Videos for Private Viewing - Ministerial Correspondence 1989-1991.

4 Ibid.

5 Ibid.
} 
While Margaret Austin was in the position of Minister of Internal Affairs for less than a year, two notable developments in the realm of video censorship took place during her tenure. The first of these was the Video Recordings Amendment Act 1990. This incorporated a measure that was described as closing a "loophole" but was arguably a move towards stricter video censorship. John Markham, writing for the Secretary of Internal Affairs, described the measure in this manner:

The amendment requires that videos approved for public exhibition to persons aged 16 years or over by the Chief Censor of Films also be classified by the Video Recordings Authority before being offered for sale or hire for "public exhibition" at a retail outlet or through advertising in a newspaper, magazine, television, radio or other medium. ${ }^{6}$

This had two practical results. One of these was to prevent video distributors from submitting videos intended for private use to the film censor, described by Margaret Austin in the following manner:

Close the 'loophole' between the two Acts, through which video retailers are allegedly circumventing the existing legislation by offering videos to the public under the guise that they are for public exhibition only. ${ }^{7}$

In effect, this meant that while some distributors had submitted pornographic video tapes to the film censor rather than the Video Recordings Authority during the period from 1987 to 1990 , anticipating a more sympathetic classification decision ${ }^{8}$, after the passage of the Video Recordings Amendment Act 1990, pornographic video tapes became the sole preserve of the Video Recordings Authority. The other result was that while films rated R16 by the Chief Censor had usually been given an unrestricted 16 certificate by the Video Labelling Body, and had not been re-examined by the Video Recordings Authority, this was no longer the case, and such films had to be referred to the VRA for classification.

The second major development occurred towards the end of the Labour Government's term, when they set up a video amnesty for people to surrender videos likely to be found to be "indecent" by the VRA. In fact, as an editorial in the Otago Daily Times pointed out, the timing of the amnesty was "criticised as a vote-catching ploy", although

\footnotetext{
${ }^{6}$ ADNB 23137 Box 5 - Video Classification/Interest Groups - Women Against Pornography 19881993.

${ }^{7}$ AAAC 7536 W5169 Box 5 - Videos for Private Viewing - Ministerial Correspondence 1989-1991.

${ }^{8}$ Examples of videos which were given different classifications by the film censor and the VRA are noted in the previous chapter.
} 
this was characterised as "a knee-jerk reaction from traders likely to be affected". ${ }^{9} \mathrm{~A}$ confidential report to the Minister of Internal Affairs dated 19 October 1990 stated that while around 500 videos had been received, this did not "fully reflect the impact of the amnesty", as it had "greatly increased public awareness about the Video Recordings Authority" and "heightened public knowledge of the video labelling system and how this operates". ${ }^{10}$ One particular owner of a number of pornographic videos, Patricia Bartlett, did not intend to surrender any tapes, as Richard Stubbings, writing on behalf of the Secretary of Internal Affairs, noted in a letter to Margaret Austin:

Ms Bartlett, Director of the Society for the Promotion of Community Standards was reported in the Dominion 26 September as possessing five indecent videos. Three of these had been classified indecent by the Video Recordings Authority, and two by the Board of Review. The article said that Ms Bartlett did not intend to submit these to the Department as part of the Amnesty. ${ }^{11}$

As Stubbings notes, private possession such as this was not an offence at this point, although it would be against the law if Bartlett "intends to exhibit these videos to other people". ${ }^{12}$ As in previous cases such as that of the "video nasties" compilation tape, Bartlett appeared to distinguish herself as distinct from the wider general public who would potentially be harmed by such material.

In terms of film censorship, the most significant development was the passage of the Films Amendment Act 1990. This restricted the Chief Censor and Deputy Chief Censors to two terms of three years, effectively putting Arthur Everard out of a job. This Act also added a new section to the Films Act 1983 which allowed the Secretary of Internal Affairs to send a film to the Film Censorship Board of Review if he or she "is dissatisfied with the Chief Censor's decision"13, whereas in the past such an action required the intervention of the Minister of Internal Affairs, a power which had never been invoked.

The election of a National Government in 1990 meant a new Minister of Internal Affairs, and the position went to Graeme Lee, for a long time an advocate of stricter censorship. While he attempted to take a more proactive role on the issue of

\footnotetext{
9 Otago Daily Times, 28 September 1990.

${ }^{10}$ AAAC 7536 W5169 Box 5 - Videos for Private Viewing - Ministerial Correspondence 1989-1991.

$11 \mathrm{lbid}$

12 lbid.

${ }^{13}$ Films Amendment Act 1990, Section 8(1).
} 
censorship than his predecessors, he was constrained by the fact he was working within a wider institutional structure, and was not entirely able to achieve his personal aims. Lee did demonstrate a desire for tighter censorship provisions, in one letter explaining that "as Minister of Internal Affairs I will be advocating a toughening up of the law as it applies to sexually explicit material", and in another noting that "the policy of the Government is to improve the standards of publications, films and videos". ${ }^{14}$ In taking a more activist role in this area, he even went as far as making enquiries with his department regarding viewing one particular type of pornographic material, prompting a response from the Secretary of Internal Affairs:

You have expressed interest in seeing the type of material on video known as bestiality. You have requested the department's advice on how you may be able to view such material. ${ }^{15}$

As in the case of Patricia Bartlett's continued possession of pornographic tapes which had been deemed "Objectionable", this suggests the role of the "third person effect", with Lee placing himself above a wider public considered to be at risk of harm from such material, while he himself would not be similarly affected. The Secretary of Internal Affairs noted that the Video Recordings Authority and the Minister "are given distinct functions which must be exercised fairly and independently", and since the only legal avenue to view such material would be at a consultation held by the VRA, if the Minister was present at such a viewing he could be seen to be interfering in the VRA's independence. ${ }^{16}$

Graeme Lee's tenure did however also demonstrate a significant degree of institutional continuity on the issue of censorship, despite his personal views on the subject. In multiple letters, he noted that he planned to use the previous Labour Government's white paper, produced as a result of the Committee of Inquiry into Pornography, "as the basis for any reform" of censorship laws. ${ }^{17}$ In response to one correspondent who linked a rape case to the influence of material available on home video, Lee noted his view that "I agree, to a certain extent, that material available on video may influence the behaviour of some people", but that "New Zealand's video standards cannot be blamed for everything that occurred on that occasion", concluding that while video had

\footnotetext{
${ }^{14}$ AAAC 7536 W5169 Box 5 - Videos for Private Viewing - Ministerial Correspondence 1989-1991.

$15 \mathrm{lbid}$.

$16 \mathrm{lbid}$

$17 \mathrm{lbid}$.
} 
been readily available in New Zealand only since 1980, "[r]ape and other crimes have occurred throughout history". ${ }^{18}$ This last point is strikingly similar to that made by his Labour Party predecessors Peter Tapsell and Michael Bassett in response to complaints about censorship standards, Tapsell noting that "[c]rime and violence, unfortunately, have been endemic to human society throughout history" ${ }^{\prime \prime}$, and Bassett using almost identical wording, stating that "[v]iolence, unfortunately has been endemic to human society throughout history". ${ }^{20}$

\section{A new Chief Censor}

Jane Wrightson was appointed as Arthur Everard's replacement in 1990, and took over the position in February 1991. ${ }^{21}$ Like Everard, she did not have a previous background in film censorship, and had worked at TVNZ for ten years in programme acquisitions, and during her final year as Head of Commissioned Programming. ${ }^{22}$ She stated on her appointment that her interest in the position was because of its "intellectual challenge", and when she took over, it was the first time that all three film censors (the Chief Censor and the two Deputy Chief Censors) were women. ${ }^{23}$ The appointment of Wrightson as New Zealand's first female Chief Censor was welcomed by some of the groups who had been strong opponents of her predecessor Arthur Everard. Indeed, reflecting back on her appointment, Wrightson considered that an important part of her role was "to repair community relationships with the office", and that she needed to talk to "really disaffected stakeholders" such as the SPCS and Women Against Pornography. ${ }^{24}$ This retrospective assessment is borne out by the archival material. Wrightson made contact with the executive of the Society for the Promotion of Community Standards, and also spoke at the Society's Annual General Meeting in 1991, where she outlined her views on the concept of "harm", suggesting

\footnotetext{
18 lbid.

${ }^{19}$ AAAC 7536 W5169 Box 5 - Videos for Private Viewing - Ministerial Correspondence 1985-1989.

$20 \mathrm{lbid}$.

${ }^{21}$ New Zealand Herald, 15 December 1990.

${ }^{22}$ Chris Watson and Roy Shuker, In the Public Good? Censorship in New Zealand (Palmerston North: The Dunmore Press, 1998), 55.

${ }^{23}$ New Zealand Herald, 15 December 1990.

24 Interview with Jane Wrightson.
} 
that it "need not be exhaustively proven but needs to be much more than a "gut reaction" or a decision based on personal dislike for the message of the film", and that "[c]ensors, in order to make sensible decisions, need to consider concepts, not a list of rules". ${ }^{25}$ Wrightson also met with members of Women Against Pornography early in her tenure as Chief Censor, after being contacted by them congratulating her on her appointment. ${ }^{26}$ However, Wrightson did express some concern that by speaking with such groups, she was "only getting one side of the story at the moment", since those supporting stricter censorship were well organised but "[t]here's no organised lobby for what the majority wants". ${ }^{27}$

Wrightson also appeared to be consciously doing things differently from Arthur Everard in some other ways. For example, she noted in 1992 that "[f]ormal public consultations were not used prior to my appointment". ${ }^{28}$ Consultations had been undertaken by both Tunnicliffe and Everard in a less formal manner, but under Wrightson, detailed records of each consultation, including the comments of specific individuals consulted, were kept and are held in Archives New Zealand. She also made a point of not allowing a single censor to view a film alone, which had sometimes happened during Everard's tenure. She explained her reasoning for both decisions in response to a correspondent to the censor's office:

All people bring personal biases to whatever they do - at this office we try to eliminate biases as best as we can. That is why, for instance, I do not permit censors to view alone, and why I hold public consultations when we are having difficulty reaching a decision. ${ }^{29}$

Wrightson also made a point of stressing that she considered herself to be taking a more conservative stance - in a memorandum to new Minister of Internal Affairs Graeme Lee, she asked that in his reply to a correspondent on censorship issues that a paragraph be added to the letter noting that there has been "a significant tightening up of the classification certificates issued" and that "[s]he is very conservative on the

\footnotetext{
${ }^{25}$ ADNB 23136 Box 7 - Pressure Groups - SPCS Society for the Promotion of Community Standards (Patricia Bartlett) 1986-1992.

${ }^{26}$ ADNB 23136 Box 7 - Pressure Groups - WAP Women Against Pornography 1984-1994.

27 Waikato Times, 23 April 1991.

${ }^{28}$ ADNB 23136 Box 6 - Controversial/Rejected Films - Rejected Films General 1955-1994.

${ }^{29}$ ADNB 23136 Box 7 - Public Correspondence - Letters - specific film titles 1976-1992.
} 
violence issue". ${ }^{30}$ This last point was made evident in one of Wrightson's earliest classification decisions, John Milius's Flight of the Intruder (1991).

\section{Notable early decisions by Jane Wrightson}

One of the first decisions by Wrightson to cause some controversy was her decision to give an R13 certificate to John Milius's Vietnam War film Flight of the Intruder, which had been viewed by Wrightson and Assistant Film Censor Anne Hannah on 6 June 1991. ${ }^{31}$ In fact, it was the first film to go before the Film Censorship Board of Review for a number of years - the last decisions to be appealed were several at the end of Tunnicliffe's tenure as Chief Censor. The distributor of Flight of the Intruder, United International Pictures, chose to appeal the decision as they felt it should have received a less restrictive rating, although they appeared to be more concerned about a possible precedent than the individual decision, stating that they were "challenging the classification on principle" and that "it would not make them money". ${ }^{32}$ Wrightson was surprised by the review of the decision, noting that she "considered that this classification was possibly the most arguable classification she had given yet, but that it was not the one she would have anticipated a review over", as it was not a particularly controversial film. ${ }^{33}$

Wrightson's submission to the Board of Review and her recorded comments in the minutes of the Board of Review's meeting provide an insight into both her decisionmaking process in this particular instance, and her approach to film censorship in general, suggesting that she was prepared to take a more conservative stance on violence than her predecessor. She made it clear that the tone of films was as important, if not more so, than the manifest content, explaining that "the Film Censor's Office had to look at messages as much as actual depictions". ${ }^{34}$ She argued that she believed that "sanitizing of violence is a worry", if a film "does not intend to explore or

\footnotetext{
30 AAAC 7536 W5169 Box 5 - Videos for Private Viewing - Ministerial Correspondence 1989-1991.

${ }^{31}$ AAAC 7536 W5360 Box 1 - Censorship Board of Review - Flight of the Intruder 1991.

32 lbid.

$33 \mathrm{lbid}$

34 Ibid.
} 
analyse aspects of the human condition", and that she was "trying to respond to public concern about the whole area of violence". ${ }^{35}$ In the case of Flight of the Intruder, Wrightson felt that the film "portrays war as an exciting and glamorous activity" ${ }^{6}$, and that she was "concerned about the inaccuracy of the portrayal of war (because it was a totally sanitized one)" and that it "might cause young children to see war as exciting, fun and glamorous because it did not show a balanced view". ${ }^{37}$ She also took aim at film distributors:

It is fair to say that the distribution industry have come to expect the mainstream films with comparatively little in the way of the usual sex violence or language elements will be classified as GA at best or RP13 at worst. They usually resist the imposition of $\mathrm{R}$ certificates and particularly dislike the R13 classification claiming that parents should decide. That may or may not be warranted but the present system demands that the Censor consider all possible classifications, irrespective of the potential impact on the box office. ${ }^{38}$

However, the Board of Review chose to reduce the rating to an unrestricted GY certificate, arguing that it "appeared carefully tailored for general exhibition - just enough violence, but not too much", and that the possible glorification of war was balanced by "the development of the relationships between principal characters" and "the absence of any macho Rambo-type characters". ${ }^{39}$

Another film to cause some controversy was the Australian documentary Sacred Sex (1991), which had been given an R18 certificate by Wrightson but had attracted the attention of the Society for the Promotion of Community Standards, who were always willing to use new legislative means to try and push for stricter film and video censorship. This was the first case in which the new amendment to the Films Act 1983 was used, as Patricia Bartlett made a complaint about the classification to the Secretary of Internal Affairs, who now had the power to refer the film to the Films Censorship Board of Review, and who chose to do so. ${ }^{40}$ The R18 decision was upheld by the Board of Review, who considered that while some people may find aspects of the film offensive, it was "not likely to be injurious to the public good" ${ }^{41}$

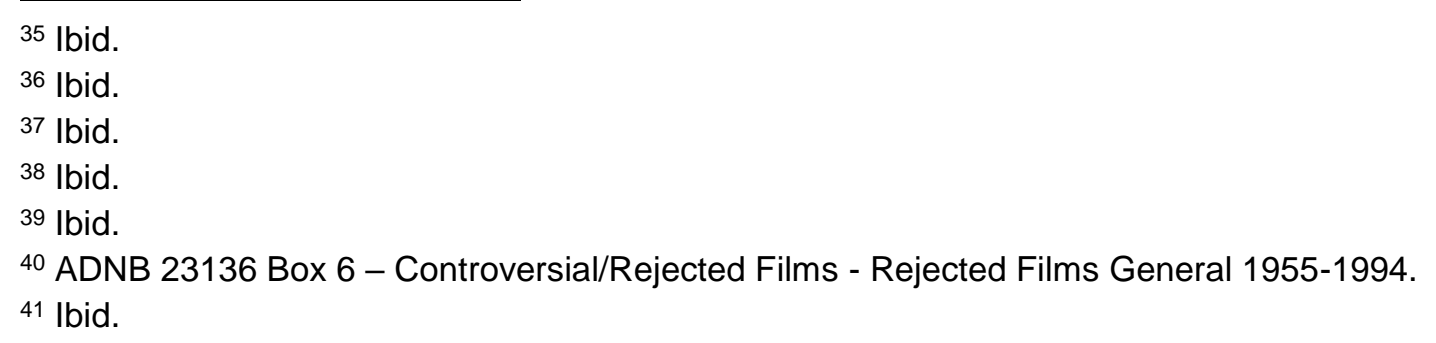




\section{Formal consultations prior to Henry: Portrait of a Serial Killer}

As previously noted, while Jane Wrightson was not the first Chief Censor to engage in consultations with members of the wider public on specific films, she was the first to fully formalise this process and keep detailed records of each individual consultation. Looking back on these consultations, Wrightson considered that they were a way "to make sure that when you're sitting in dark rooms in Wellington, you're not just talking amongst yourselves". ${ }^{42}$ This suggests that an outside perspective was perceived as necessary in order to more effectively rationalise censorship decisions, and arguably reduce the potential for them to be controversial and contested. The most notable of these consultations was for John McNaughton's Henry: Portrait of a Serial Killer, which Wrightson banned. However, before Henry, she carried out consultations on four other films - the Steven Seagal-starring action film Out for Justice (1991), avant-garde short film Damned If You Don't (1987), Ken Russell's film Whore (1991), and Hong Kong action film Queen of the Underworld (1991). None of these films were cut or banned, but these consultations demonstrate that Wrightson was seriously taking into account the Hail Mary court case and Justice Heron's ruling that Arthur Everard had erred in not consulting with "representatives of the affected group", in the case of that film the "affected group" being members of the Catholic faith. ${ }^{43}$ For example, for Queen of the Underworld, those consulted "represented a cross section of the Chinese community" as "an affected group", and for Whore, those chosen were characterised as "a broad community cross section with representation from the specifically affected group (Prostitutes)". ${ }^{44}$ In the case of Damned if You Don't, an experimental short film which addressed sexual repression among nuns, there is no mention in the record of why those consulted were chosen, but the consultation group included 15 "practicing Catholics" including several nuns. In this case, Wrightson clearly was following the practice of consulting those from the "affected group". 45 Unlike Henry or Salò, none of these consultations resulted in widely polarised opinions among those who viewed the

\footnotetext{
42 Interview with Jane Wrightson.

${ }^{43}$ AAAC W5169 7536 Box 15 - Chief Censor and Departmental Responsibility - Hail Mary 1986-1988.

${ }^{44}$ ADNB 23136 Box 6 - Controversial/Rejected Films - Public Consultations 1991-1993.

45 Ibid.
} 
film, and the Chief Censor's decisions led to no major public controversy, suggesting a cautious approach by Wrightson and a desire to avoid the type of controversies which had occurred during Arthur Everard's tenure.

\section{Henry: Portrait of a Serial Killer - historical narrative}

One of the most widely publicised and widely discussed bans of a film intended for cinematic exhibition in New Zealand was that of John McNaughton's Henry: Portrait of a Serial Killer in 1992. This was particularly notable at the time, as far fewer films were being banned by the Chief Censor's office. Recent bans had largely been of video pornography, and the most recent ban of a $35 \mathrm{~mm}$ film had been the pornographic film A Very Small Case of Rape in 1986. The most recent bans of nonpornographic films in fact pre-dated Arthur Everard's tenure as Chief Censor, with Cannibal Holocaust and Chained Heat being banned in 1983, and soft-core sci-fi sex film Flesh Gordon being banned in early $1984 .{ }^{46}$ Henry was originally completed in 1986, and had been intended as a low-budget horror film for the booming video market - the producer who commissioned it "wanted a horror film but did not care what the subject matter was". ${ }^{47}$ However, McNaughton came to the realisation while watching the dailies of the film that it "could be released theatrically" rather than simply being relegated to video. ${ }^{48}$ Indeed, the production company chose not to release Henry on video, as they felt it had no commercial value, but McNaughton had his film transferred to video so he could distribute copies of it to attempt to raise interest in a release. ${ }^{49}$ It was not until the late 1980s that the film was submitted to the Motion Picture Association of America's ratings board, as a distributor was interested in the film but wanted it to have an $\mathrm{R}$ rating. ${ }^{50}$ However, it was given the much more prohibitive $\mathrm{X}$ rating with no suggestion of any cuts that might reduce the classification. Steffen Hantke has argued that the classification was a reflection of "[h]ow objectionable the

\footnotetext{
${ }^{46}$ In a press release on the initial ban of Henry, Wrightson stated that "[t]he last non-pornographic film banned for cinema release was Turkey Shoot in 1982", a decision that was overturned on appeal in 1983.

${ }^{47}$ Shaun Kimber, Henry: Portrait of a Serial Killer (Basingstoke: Palgrave Macmillan, 2011), 5.

48 lbid., 11.

$49 \mathrm{lbid} ., 17$.

50 Ibid., 21.
} 
film appeared to most viewers", even though its makers didn't expect such problems - the classification reflected not just the content of the film, but its bleak tone and overall impact on the viewer. ${ }^{51}$ The film also faced censorship problems in the United Kingdom, Tom Dewe Mathews noting that it "took more time to censor than almost any other film in modern times". ${ }^{52}$ It was first cut for its cinema release, and while British Chief Censor James Ferman had stated that he would not pass the film on video, it did get a video release after its resubmission "presented [him] with another opportunity to chip away" at it. ${ }^{53}$

As this suggests, like other controversial films such as Life of Brian and Hail Mary, Henry arrived in New Zealand after it had already faced controversy and censorship in a number of other countries. The film did not appear before the Chief Censor until 1992, when the New Zealand Federation of Film Societies intended to screen it as part of their annual film festival. The Film Festival organisers anticipated possible censorship problems with Henry, with their write-up of the film in the advance programme focusing on the issue:

We're not certain how film censorship in New Zealand will handle Henry, so we're not taking bookings until we have a certificate. We assure you we wouldn't be importing this film into New Zealand if we didn't think there was a good case to be made for showing it. ${ }^{54}$

Confirming these fears, Jane Wrightson rejected the film "on the grounds that the exhibition of the film is likely to be injurious to the public good" due to "horror, violence, cruelty and sex". ${ }^{55}$ Wrightson had initially been made aware in May of the intention to screen the film, and because she considered that the film "would require careful consideration", a formal consultation involving 19 members of the public was held. ${ }^{56}$ This group of people was described by Wrightson as "a cross section of members of the public and those offering expert opinion". ${ }^{57}$ This group included film critics and filmmakers, public servants, a forensic psychologist, and representatives from the Family Violence Prevention Co-ordinating Committee. In her submission to the Board

\footnotetext{
51 Steffan Hantke, "Violence Incorporated: John McNaughton's "Henry: Portrait of a Serial Killer" and the Uses of Gratuitous Violence in Popular Narrative," College Literature 28, no. 2 (2001): 32.

52 Tom Dewe Mathews, Censored (London: Chatto \& Windus, 1994), 263.

53 lbid., 266.

${ }^{54}$ ADNB 23136 Box 6 - Controversial/Rejected Films - Henry Portrait of a Serial Killer 1991-1993.

$55 \mathrm{lbid}$.

$56 \mathrm{lbid}$.

$57 \mathrm{lbid}$.
} 
of Review hearing, Wrightson explained that those chosen for the consultation were based on the precedent set by the Hail Mary decision that "any consultation should include members of the affected class", and thus she selected "a majority of filmgoers whose views [she] could not predict", because in her view, cuts or a ban "impacted on the right of the filmgoers to make up their own minds". ${ }^{58}$ Others consulted "had professional expertise" which Wrightson argued "could add to the debate", and two film critics, both "strongly anti-censorship", were chosen "so someone could then review the film and thereby inform the public" about it. ${ }^{59}$ There were a range of views on the nature of the film - some saw a degree of artistic merit, while others saw it as lacking in quality and potentially leading to copycat violence. Several of those viewing the film suggested that the film's portrayal of violence was not in fact gratuitous. For example, one suggested that films were "more responsible when violence is shown realistically", and another argued that a film such as Young Guns had "a shallow basis and as being more dangerous [than Henry] - because of the fantasy elements of violence contained in it". ${ }^{60}$ Of the 19 , seven recommended R18 uncut, three R18 with cuts, and nine recommended rejecting the film, so those recommending an outright ban were a slight minority. However, Wrightson noted later in her detailed written decision on the film that the intended purpose of this consultation was "not to assist...in reaching a decision", but to "assist...in forming an opinion of the film, in terms of the Films Act [1983]", although this seems perhaps somewhat contradictory, as forming an opinion on any film is an essential part of the censorship decision-making process. ${ }^{61}$ She later commented on the consultation in her submission to the Films Censorship Board of Review, noting that of the five such consultations she had undertaken, Henry was the only one "where nearly half of the participants voted to reject the film (more than half if you exclude the film critics)", and that because "an audience which tended to oppose censorship" came to such a view, it could be inferred that "a wider audience would support that move" ${ }^{62}$ Wrightson also took particular note of the views of women among the consultation group, and how they differed from those of men:

\footnotetext{
58 Ibid.

59 lbid.

$60 \mathrm{lbid}$.

61 lbid.

62 lbid.
} 
The dominant effect is also perceived differently by women and men if the consultation is anything to go by. Men do not seem to place as much importance on the way the women are presented in their killing or death, feeling that the atrocities are committed on both men and women. ${ }^{63}$

Henry was formally refused classification on 26 June 1992, and Wrightson noted that while the Chief Censor was "not statutorily required to give reasons for [her] decisions and a Chief Censor has never provided such information ${ }^{64}$, due to the "unusual nature of the decision", she had chosen to provide a detailed record of the reasons for the ban. ${ }^{65}$ The way in which the film portrayed violence against women was a key factor in the ban - Wrightson noted that "despite Henry clearly not being a rapist", the way that murdered women were presented meant that "the dominant effect is as much to sexualise the deaths as to inspire horror in them". ${ }^{66}$ However, while Wrightson noted that "[t]he job of the censor is to evaluate material against a set of statutory criteria, irrespective of personal views", there does appear to be a degree of personal value judgement in the case of Henry. Wrightson did not consider it to be a "serious" examination of its subject matter, and thus gratuitous in its presentation of violence. While she thought that it had "some artistic merit", "[d]ue to its low budget origins and adherence to the fundamentals of the genre ["stalk and slash"] however, it remains a "B" grade picture". ${ }^{67}$ She further argued:

What sets it apart from a serious characterisation or indeed from other horror films is its prurience and realism. The former type of film does not need high levels of gratuitous violence and cruelty to make its point; the latter provides comparatively harmless unrealistic entertainment. ${ }^{68}$

While several of those whom Wrightson had consulted suggested that the film could be passed as R18 with cuts, Wrightson herself rejected the idea of cutting the film, as she considered the overall tone of the film problematic, rather than any specific scenes which could be edited or removed. She argued that "remov[ing] the more extreme examples of the horror would only serve to sanitise the film and belie one of its themes", and that cutting it "does not address the issues permeating the film's subtext

\footnotetext{
63 Ibid.

${ }^{64}$ While it was true that the Chief Censor was not statutorily required to provide reasons for his or her decision beyond that identifying the legislative grounds for the decision, both Arthur Everard and Bernard Tunnicliffe had provided more detailed reasoning for some of their decisions in response to correspondence from members of the public.

${ }^{65}$ ADNB 23136 Box 6 - Controversial/Rejected Films - Henry Portrait of a Serial Killer 1991-1993.

$66 \mathrm{lbid}$.

$67 \mathrm{lbid}$

$68 \mathrm{lbid}$
} 
of its treatment of women". ${ }^{69}$ Other issues raised by Wrightson, included what she considered the film's "amoral stance", in that "noone [sic] is chasing Henry... and Henry is never caught"; that the film's depictions of violence could potentially "interest predisposed individuals"; and that the film festival context made no difference to her classification, as she did not "accept the argument that people who attend this particular film festival are any more mature or immature than any other filmgoer" ${ }^{70}$

The Federation of Film Societies soon appealed Wrightson's decision, and Henry was re-examined by the Films Censorship Board of Review on 14 July 1992. The Board was chaired by Dr Hilary Lapsley, a Women's Studies lecturer and psychologist who had been a member of the Ministerial Committee of Inquiry Into Pornography. ${ }^{71}$ They upheld the ban in a majority 4-2 decision, agreeing with Wrightson that "some of [Henry's] killings of women were sexualised", and that while it had "some degree of artistic merit", this was not sufficient to outweigh "the possibility of desensitising its audience to violence". ${ }^{72}$ Henry was also seen by the board as being a more extreme film than other, similar films that had been passed for public exhibition:

The Board may have regard to the number of films of a similar nature previously approved for exhibition. However, the Board felt that Henry was not necessarily comparable to other films in circulation, because the graphic quality and sheer cumulative nature of its violence seemed to go further than most other portrayals of violence in films in circulation. ${ }^{73}$

Like Wrightson, the Board was concerned about the tone of the film, arguing that it "did not attempt to educate its audience", and also agreed that being intended for a film festival would not "make any difference to whether or not it would be likely to be injurious to the public good". ${ }^{74}$

While the options for public exhibition of Henry had been exhausted by the Board of Review's rejection, there was still the possibility of submitting the film to the Video Recordings Authority. Neither the Chief Censor nor the Board of Review had recommended cuts to the film in order to allow it to be granted a certificate. Indeed, as

\footnotetext{
$69 \mathrm{lbid}$.

70 Ibid.

${ }^{71}$ AAAC 7536 W5169 Box 5 - Videos for Private Viewing - Ministerial Correspondence 1989-1991. Lapsley co-authored the Ministerial Committee of Inquiry Into Pornography report under her former name, Hilary Haines.

72 Ibid.

73 lbid.

74 Ibid.
} 
Watson and Shuker note, the film festival directors "would have refused" such cuts due to their desire to show films "as the director intended". ${ }^{75}$ This is confirmed by Wrightson's submission to the Board of Review, where she notes that they "advised me in strong terms of their policy that they refuse to screen excised films". ${ }^{76}$

However, after its submission by a different distributor, the Video Recordings Authority did pass Henry on video with cuts, with an R18 certificate. In contrast to Wrightson's dismissal of the film's quality, the VRA's detailed Reason for Decision argues that the film "is well scripted, acted and directed - there is nothing " $\mathrm{B}$ " grade about "Henry"”. ${ }^{77}$ The VRA also disagreed with Wrightson's characterisation of the deaths of women in the film as sexualised, arguing that despite the fact that Henry's victims are "naked, or semi-naked", "such depictions do not appear to have the effect of titillation". ${ }^{78}$ The VRA report also suggested that while the violence in the film is occasionally "gruesome and graphic", "many disturbing scenes are depicted with some restraint". ${ }^{79}$ Over two and a half minutes of cuts were required by the VRA, comprising the entirety of the "home invasion" scene where the characters Henry and Otis film themselves engaging in a multiple murder, and watch it at home later, as well as a brief sequence where the video is playing again while Otis is asleep on the couch, since this material was considered exploitative and made "a voyeur out of the viewer". ${ }^{80}$ The specific context of video viewing, rather than cinema viewing, was a factor in this decision:

[The scene] put[s] forward the notion of committing and videotaping acts of appalling violence within the confines of the family home with the purpose of later watching the tapes as entertainment. Given the context of the video recording, it is felt that the concept of filming a home video - both of this nature and for this reason - is injurious. ${ }^{81}$

However, while these were the only excisions required by the VRA, and the only ones recorded in the archival sources, the version of Henry released on video in New Zealand was in fact cut by over four and a half minutes, for two reasons. The first was that the distributor had submitted the already cut Australian video version to the VRA,

\footnotetext{
${ }^{75}$ Chris Watson and Roy Shuker, In the Public Good? Censorship in New Zealand (Palmerston North: The Dunmore Press, 1998), 56.

${ }^{76}$ ADNB 23136 Box 6 - Controversial/Rejected Films - Henry Portrait of a Serial Killer 1991-1993.

77 lbid.

78 lbid.

79 lbid.

80 lbid.

$81 \mathrm{lbid}$.
} 
which may partly explain the VRA's reference to the film's "restraint". This version shortened two of the "tableaux" of Henry's murders, including the most notorious of these which showed a semi-naked prostitute with a glass bottle embedded in her face. There were also several cuts to the "home invasion" sequence", although these were not evident in the New Zealand version as the entire sequence was removed. ${ }^{82}$ Secondly, the distributor made the decision to remove additional material not required by the VRA. While the second cut only required 21 seconds so as not to show Henry and Otis's video playing on the television, an additional 27 seconds were removed, so we do not see Henry and Becky in the lounge at all, presumably as this sequence would make little sense if we were not aware that Henry was turning off the video recording. Quoted in a newspaper report on the VRA's decision, Wrightson stated that she "does not condemn" the decision to pass the film with cuts, and that "video has far less impact than cinema", although the article does not explain her reasoning, and it is likely she was not aware of just how extensive the cuts were. ${ }^{83}$ The New Zealand video release [Figure 4] had the same cover as the Australian one. Although the proclamations on the front cover "The film they tried to ban!" and on the back "1992's most controversial film!" originally referred to the Australian censorship context, they also can be seen to apply to the New Zealand context as well. As Kimber notes in the US context, "[a] recurring theme in much of the packaging for Henry is this deliberate trading, as a marketing ploy, upon the cultural and classificatory furore associated with the film." ${ }^{84}$ While exploiting the film's controversy, the video cover made no mention of the extensive cuts, and even included a still on the back of Henry and Otis watching their home made "snuff movie", despite the fact that this scene was completely absent from the actual tape. Henry was eventually passed uncut for DVD release in 2010 with an R18 certificate, with the note "[c]ontains violence and sexual violence", although the record of the decision made no reference to the previous controversy surrounding the film or gave any detailed explanation. ${ }^{85}$

\footnotetext{
82 Refused-Classification.com, http://www.refused-classification.com/censorship/films/henry-portraitof-a-serial-killer-1986.html. The cuts described on the website match up with those on the copy of the original New Zealand VHS release in my possession.

83 Sunday Star, 24 January 1993.

84 Kimber, 25.

85 Office of Film and Literature Classification online database, http://www.classificationoffice.govt.nz/DDA/Pages/Screens/DDA/WelcomePage.aspx.
} 


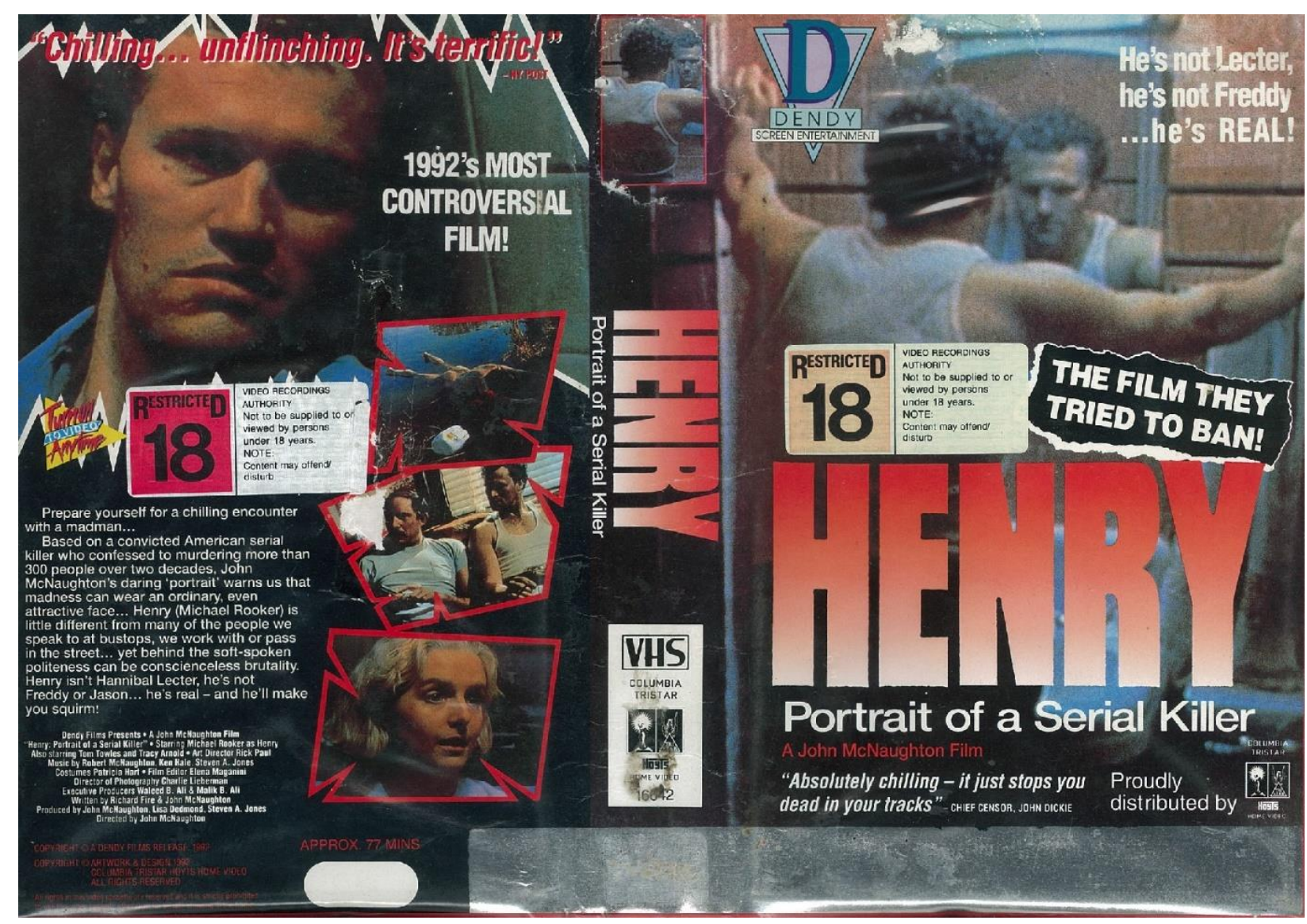

Figure 4: The New Zealand VHS cover of Henry: Portrait of a Serial Killer. The middle photograph on the back of the cover illustrates the excised sequence of Henry and Otis watching their home video.

Henry: Portrait of a Serial Killer - the "home invasion" scene

As Shaun Kimber notes, the so-called "home invasion" scene "has been consistently flagged up as the most controversial in the film". ${ }^{86}$ Since it was the target of excisions not just by New Zealand's Video Recordings Authority, but also by censors in Australia and the United Kingdom, it warrants some discussion in depth. In both these countries, the sequence was reduced, but not completely eliminated, although making multiple cuts interrupted the flow of what in the uncut version was a continuous shot of the home video. However, in the case of the UK video version, the censorship went further

${ }^{86}$ Kimber, 100. 
than just removing material. As Tom Dewe Mathews notes, British Chief Censor James Ferman "stepped outside his job description" by taking the shot of Henry and Otis watching the video on the couch, originally placed after we had watched their crimes play out on video in real time, and moving it to earlier in the sequence ${ }^{87}$. Thus the intent of the scene, that "any vicarious pleasure for the audience is cut short by the creeping realisation that Henry and Otis are watching the same scene at the same time as you" is subverted by removing the "creeping realisation" and making it overt. ${ }^{88}$ While James Ferman's tampering with Henry is perhaps the most contentious example of censorship of the film, what happened to the New Zealand video version is arguably an even more drastic example of the power of censorship authorities to alter the meaning of a film text. Rather than simply altering or reducing a major sequence of the film, it removes it completely, as the film cuts from Henry and Otis arriving at the house where they commit their crimes, to a later scene of Becky talking on the phone, leaving any crimes only very vaguely implied. One of the key questions raised by the targeting of this particular sequence for censorship is whether it is indeed "exploitative" as the VRA suggested, or if it is an important sequence in the structure and meaning of the film as a whole. Kimber suggests that the scene's importance lies in its "centrality within Henry's mode of narratively orchestrating its violent attractions, signalling the crescendo of the film's violent spectacle and registering a key shift away from the slow revelation of that spectacle characteristic of its earlier scenes". ${ }^{89}$ In the UK and Australian versions of the film, this effect is somewhat preserved, but in the New Zealand video version, it is completely lost. In her study of home video spectatorship, Caetlin Benson-Allott notes that "thrillers and horror movies were among the first motion pictures to interrogate contemporaneous shifts in motion picture technology", arguing that films such as David Cronenberg's Videodrome constitute "dystopian reflections on consumer electronics". ${ }^{90}$ Henry's use of home video recording technology as a narrative and thematic device suggests it can be placed in the same category, as like the films that Benson-Allott examines, it "turn[s] [its] preoccupation with attracting an audience into a thematic contemplation of how [it] will reach that

\footnotetext{
87 Mathews, 268.

88 Ibid., 267.

89 Kimber, 100.

${ }^{90}$ Caetlin Benson-Allott, Killer Tapes and Shattered Screens: Video Spectatorship from VHS to File Sharing (Berkeley: University of California Press, 2013), 17
} 
audience". ${ }^{91}$ Tom Dewe Mathews argues in the UK case that censorship was often "merely a confirmation of the director's intentions"92 - the apparently exploitative and voyeuristic nature of the sequence is its entire purpose, and in considering the scene "exploitative" and voyeuristic, the Video Recordings Authority were perhaps demonstrating that this was just as true in New Zealand. Jeffrey Sconce also argues that particularly in relation to this scene, the "incessant attention to technique and effect in critical accounts" of Henry suggest a mode of identification "with the director as an abstract author of the text", rather than with any particular character or characters. ${ }^{93}$ Therefore the removal of the scene in its entirety, as well as the relegation of the film to home video rather than the prestige of a film festival, arguably takes Henry back to its origins as low-budget horror intended for the video market, eliminating the fact that it had transcended these origins and making it appear a more exploitative film rather than less. Indeed, future Chief Censor Bill Hastings, who worked for a time at the VRA, reflected back on the Henry decision:

In fact we cut the heart of the film out... what that was meant to do was say to the spectator "What the heck are you watching for entertainment?". But by removing that scene, we essentially made the film far worse than it was. ${ }^{94}$

This was arguably exacerbated by the video packaging highlighting the controversy around the film. This created a rather different viewing context than the originally intended film festival release, as anyone viewing the film would be aware of the censorship controversy around the film but perhaps not its arguable artistic merit.

\section{Henry: Portrait of a Serial Killer - analysis}

As with many cases of film censorship, Henry's fate at the hands of New Zealand's censorship authorities goes far beyond the issue of manifest content, and into many other areas of discursive legitimacy. As Kimber notes, "[t]he divergent reactions to

\footnotetext{
91 lbid., 17.

92 Mathews, 265.

93 Jeffrey Sconce, "Spectacles of Death: Identification, Reflexivity, and contemporary Horror." In Film Theory Goes to the Movies, edited by Jim Collins, Hilary Radner and Ava Preacher Collins (New York: Routledge, 1993), 117.

94 The Naughty Bits, Episode 2 (2014).
} 
Henry have therefore contributed to and been promoted by the very challenges that it poses to audiences, critics and regulators in working out how to categorize, think about and respond to it", ${ }^{95}$ and while he only discusses the context of the USA and UK, such an assessment holds true in New Zealand as well. Wrightson argued that not merely the content, but the tone and overall impact were the key issues - the violence was not seen as sexual, but seen as sexualised, and that the film was "neither the most gory nor the most thrill-seeking" that she had seen. This is consistent with her earlier statement in the case of Flight of the Intruder that "the Film Censor's Office had to look at messages as much as actual depictions", although the decisions are arguably inconsistent with each other in different ways. The Board of Review seemed to place more weight than Wrightson on the idea of manifest content, mentioning the "graphic quality and sheer cumulative nature" of the violence in the film. Some of the other issues considered were the film's perceived impact, the viewing context, and the views of third party authorities. In the case of perceived impact, Wrightson considered the possibility that "predisposed" people would be attracted to the violence on display, while the Film Censorship Board of Review took a broader view, arguing that audiences in general might be "desensitised" to violence by the film. Neither Wrightson nor the Board of Review saw the context of the film being screened at a film festival as a significant factor in their decisions, although the Video Recordings Authority did consider the context of home video as a justification for the excisions they required from the film. The role of third party authorities was most evident in the public consultation conducted by Wrightson, and illustrates the way in which she gave certain viewpoints greater discursive legitimacy in her decision-making process, particularly those of women. This suggests that she may have considered them a significantly "affected" group in terms of the precedent set by Hail Mary court case, as the violence against women in the film was perceived as sexualised. However, she did also make some reference to academic research on depictions of violence in media in her decision, noting in her written decision that while "research in this area is rarely clear", she felt that there was enough evidence to warrant caution. ${ }^{96}$ Lobby groups were not a significant factor in the discourse around Henry, perhaps because the ban from cinematic release gave them nothing to protest about, and while in some other public

\footnotetext{
95 Kimber, 61.

${ }^{96}$ ADNB 23136 Box 6 - Controversial/Rejected Films - Henry Portrait of a Serial Killer 1991-1993.
} 
consultations, Wrightson included members of the Society for the Promotion of Community Standards and Women Against Pornography, this was not the case for Henry.

Henry was, and remains, an extremely divisive film, so it is not surprising that there were a variety of opinions regarding its level of artistic merit, and that this was one of the most significant factors in the competing censorship discourse around the film. This discourse was also tied up with assessments of Henry's level of cinematic "realism". In discussing the film's critical reception on its initial UK cinema release, Hallam and Marshment note that "the discourse of realism was used to both praise and condemn the film"97, and this was also true of the film's New Zealand censorship reception. Wrightson and the Video Recordings Authority expressed rather different views on the film's artistic merit, with the latter considering it a film of significant quality, while Wrightson described it as "competently made but no more than that". ${ }^{88}$ However, reflecting back on her decision, Wrightson saw more merit in the film, arguing that it was "an enormously well-made film" but that "because it was well-made, that's kind of what the problem was". ${ }^{99}$ Elaborating somewhat on this view, Wrightson suggested that if a film is "badly made", "the classification issues are relatively simple, because you don't believe it, you can laugh at it." 100 Comparing Henry to other horror films, Wrightson argued that they were generally less realistic and provided "comparatively harmless unrealistic entertainment". This is somewhat similar to the reasoning employed by British Chief Censor James Ferman in justifying passing Friday the $13^{\text {th }}$ but banning The Texas Chain Saw Massacre. Ferman argued that "[t]he nice thing about fantasy is all the time you can keep reminding yourself, "I can't get hurt, no one's going to get hurt, it's just make believe." ${ }^{101}$ However, Wrightson's decision on Henry somewhat contradicts her reasoning for initially giving Flight of the Intruder an R13 certificate for portraying war violence as "glamorous" and "sanitized", something certainly not true of the violence in Henry.

\footnotetext{
97 Julia Hallam and Margaret Marshment, Realism and popular cinema (Manchester: Manchester University Press, 2000), 236.

${ }_{98}^{98}$ ADNB 23136 Box 6 - Controversial/Rejected Films - Henry Portrait of a Serial Killer 1991-1993.

99 Interview with Jane Wrightson.

100 lbid.

101 Mathews, 228.
} 
Since the content of Henry on its own was not a significant factor in discourse around its censorship and classification, much of the discussion focused on the tone of the film, and the way it portrayed violent material. This was a key factor in the decisions of both Wrightson and the Board of Review, and reflected the fact that the film divided audiences, critics and censors. The case of Henry suggests that films tend to be more problematic in censorship terms if there is no easy single reading of them, and they can be read in seemingly contradictory ways. As Hantke notes, "[c]onsidering how simple and straightforward the film's plot is it is surprisingly difficult to summarize it in a coherent fashion"102. For example, the Australian film censors' synopsis in their initial decision to ban the film describes the film's events in a very simplistic manner that does not really capture the tone of the film, and in stressing the violence and killing, portrays the film as being more exploitative than it actually is:

Fictional dramatisation tracing the activities of Henry, a cold-blooded psychotic killer who shares a modest flat with a prison acquaintance, Otis, and Otis's victimised sister, Becky. Henry introduces Otis to indiscriminate thrill killing. He eventually kills both Otis and Becky. ${ }^{103}$

In addition, the fact that the film "entirely frustrate[s] the audience's desire to understand the protagonists and ascribe any meaning to the killings they carry out"104 has led to both positive and negative responses. While many critics have seen this lack of easy answers as one of the film's strengths, both Wrightson and the Board of Review saw it otherwise. Wrightson considered that Henry was not a "serious consideration" of its subject matter, even suggesting its tone was "amoral" for not overtly condemning the protagonists. The Board of Review went further, arguing that the film "did not attempt to educate", and "appears to make no judgement" on the behaviour of the main characters, suggesting that the difficulty of determining a clear "message" from the film was partial grounds for stricter censorship.

While film censorship is often presented as being an objective process based on clear legislative guidelines, its inherently subjective nature is often revealed by the contentious and unclearly defined language used to justify controversial censorship decisions, and this is very much the case with Henry. Terms such as "gratuitous" and

\footnotetext{
102 Hantke, 32.

103 ADNB 23136 Box 6 - Controversial/Rejected Films - Henry Portrait of a Serial Killer 1991-1993.

${ }^{104}$ Louis Bayman, "Do Serial Killers Have Good Taste?". In Murders and Acquisitions:

Representations of the Serial Killer in Popular Culture, edited by Alzena MacDonald, 145-162. New York: Bloomsbury, 2013147.
} 
"exploitative" were used as justification to ban or cut Henry. However, something that is seen as "gratuitous" by one viewer may be seen an inherent and necessary element of a film or genre by another. As Linda Williams notes regarding the "body genres" of pornography, horror and melodrama, sex, violence, and emotion are fundamental elements of the sensational effects of these three types of films, and thus "the designation "gratuitous" is itself gratuitous." 105 Hantke makes a similar point, arguing that "discussing the uses of gratuitous violence is in itself an oxymoronic project"106 Wrightson's decision on Henry seems to have such an inbuilt contradiction - if the violence in the film is "gratuitous", and therefore unnecessary, how would making cuts to the film "belie one of its themes"?

One particularly contentious issue in the case of Henry is its genre classification, and any assumptions such a classification might entail. Wrightson characterised the film as "rooted in its origins in the "stalk and slash" genre of horror film", and not transcending these origins, displaying some originality but hampered by its "adherence to the fundamentals of the genre". ${ }^{107}$ While Wrightson appears to have tried to understand the film by placing it in a fixed genre, Kimber notes that Henry's genre classification in different writings on the film is extremely varied, including "slasher film", but also "horror film", "crime film", "post-modern horror", "serial killer film", and by its director himself, a "character study" which "blends horror and art". 108 Louis Bayman appears to agree with McNaughton's own assessment, arguing that the film "confuse[s] categories of art and exploitation, and bring[s] the popular pleasures of violence and horror alongside a detachment that encourages social commentary, aesthetic contemplation, and artistic reference". ${ }^{109}$ Hallam and Marshment note also that Henry was "[t]ermed the 'new brutalism' by the popular press" in the early 1990s, although it was actually made a number of years earlier than films with which it was grouped in this category, such as Quentin Tarantino's Reservoir Dogs (1992). ${ }^{110}$ Indeed, it was "somewhat out of place" when it was finally granted a wide release, as it had been intended as an alternative to "hypermasculine cartoon-action violence" of

\footnotetext{
105 Linda Williams, "Film Bodies: Gender, Genre, and Excess," Film Quarterly 44, no. 4 (1991): 3.

106 Hantke, 31.

107 ADNB 23136 Box 6 - Controversial/Rejected Films - Henry Portrait of a Serial Killer 1991-1993.

108 Kimber, 61.

109 Bayman, 158.

110 Hallam and Marshment, 224.
} 
the mid-1980s. ${ }^{111}$ Carol Clover, who does not regard Henry as a horror film ${ }^{112}$, describes the slasher film as "the immensely generative story of a psychokiller who slashes to death a string of mostly female victims, one by one, until he is subdued or killed, usually by the one girl who has survived". ${ }^{113}$ This description hardly befits Henry, a film where the most graphically depicted murders are against male victims, and the murders of females are largely shown in the aftermath only (the opening "tableaux" of Henry's previous murders) or implied and not shown at all (the final murder of Becky). Indeed, Sconce argues that some film critics have made the point of distinguishing Henry from slasher films, the film being "celebrated...in terms of its "intelligence" and stark "realism"', as opposed to the more formulaic and less worthy slasher films. ${ }^{114}$ This difficulty on pinning down a clear meaning was even more pronounced in the case of the next major film censorship controversy in New Zealand, Pier Paolo Pasolini's Salò, which was also "a multifaceted text, able to move between the realms of art and exploitation". ${ }^{115}$

\section{Salò, or the 120 Days of Sodom - historical narrative}

Pier Paolo Pasolini's final film before his 1975 murder, Salò, or the 120 Days of Sodom, has been "seeped in controversy since it was released". ${ }^{116}$ However, this controversy did not make it to New Zealand shores until nearly two decades after its original release. Salò first came before the New Zealand film censors in 1976, and was banned on 2 September under the then-current 1961 Cinematograph Films Act with little fanfare or comment. While such a ban was somewhat unsurprising prior to the liberalisation of New Zealand's film censorship with the 1976 Cinematograph Films Act, what was perhaps more notable was the ban of the film in 1993. Indeed, Chief

\footnotetext{
111 Kimber, 59-60.

112 Carol J. Clover, Men, Women, and Chain Saws: Gender in the Modern Horror Film (London: BFI, 1992), 229.

113 Ibid., 21.

114 Sconce, 104.

115 Hobbs.

${ }^{116}$ Derek Dalton and Catherine Schubert. "When Classification Becomes Censorship: An Analysis of the Neutralisation and Resistance of Film Censorship in Contemporary Australia." Griffith Law Review 20, no. 1 (2011): 59.
} 
Censor Jane Wrightson noted in her detailed written decision "that it is most unusual to reaffirm a ban issued nearly twenty years ago". 117

Jane Wrightson held a public consultation on 13 December 1993, "[g]iven the nature of the film and the differing interpretations which can be applied to it". ${ }^{118}$ The 24 people who attended this screening included representatives from Women Against Pornography, the police, the National Council of Women and Victoria University, as well as "general public representatives, with relevant skills (eg. filmmaking, legal, film reviewing) or broad filmgoing habits". ${ }^{119}$ Wrightson noted that in selecting the "general public representatives", those with "strong pro- or anti- censorship views" were not chosen because she considered that "their response would be clear and would not unduly assist the Office" in terms of making a decision on the film. ${ }^{120}$

Salò prompted a variety of responses from this audience. Wrightson noted that "[a]ll described the film as "repellent". ${ }^{121}$ Some argued that this was not a reason to ban the film, one arguing "I can't ban this film, nothing is glamorized", while another considered it not to be pornographic as it was "at no time gratuitous, everything had a point". Police psychologist lan Miller had a rather different interpretation of the film, considering it "cruelty and violence dressed up as art" and arguing that it would "stimulate those with paraphiliac tendencies". ${ }^{122} \mathrm{He}$ also suggested that those in the audience who had seen the film as having artistic merit were evaluating the film "from a middle class value system", detached from the reality of what was being portrayed. ${ }^{123}$ In a letter to Wrightson after the film had been banned, Miller stated that he had "no doubt that you have made the correct decision in this case", and went on to make a rather extraordinary comment about the director Pasolini:

Having seen Pasolini's "Decameron" I can appreciate some of his merits as a director, but equally I can also understand why someone wanted to murder him! (Personally I would rather have him in therapy to examine his fixation with matters anal and excretive but clearly his killer felt the need for a more direct treatment). ${ }^{124}$

\footnotetext{
117 ADNB 23136 Box 6 - Controversial/Rejected Films - Salo 1993-1994.

118 lbid.

119 Ibid.

120 lbid.

121 Ibid.

122 Ibid.

123 Ibid.

124 Ibid.
} 
Shirley Morton from Women Against Pornography had a similar view, calling the film "a middle class version of a porn video". ${ }^{125}$ Of the 24 people, one recommended an RP16 rating, 15 suggested R18, and the remaining 8 argued for a ban, including both psychologists and both Women Against Pornography representatives. None of those who supported passing the film recommended any cuts. ${ }^{126}$

Ultimately, Wrightson chose to ban the film. While she recognised the historical and artistic importance of Salò, and considered it "powerful and compelling", she argued that such factors "do not sufficiently outweigh the other criteria", and that "the fascist metaphor arguably seems largely lost, overtaken by Pasolini's fascination with descriptions and depictions of paraphilia". ${ }^{27}$ Wrightson appeared to place particular importance on the opinions of the two psychologists who viewed the film, singling out their opinions for comment in her written decision and noting that they "indicated that such a film would be of strong interest to those with paraphiliac inclinations". ${ }^{128}$ Similarly to her reasoning in the decision to ban Henry: Portrait of a Serial Killer, Wrightson did not consider that cutting the film was a viable option, since cuts would "sanitise the film, directly detract from the issues explored by Pasolini, and would not adequately address the dominant effect of the film". ${ }^{129}$ Wrightson also argued that "[t]he manner or way the film is constructed and what is meant by the director is what chiefly causes debate", and that it can be read in multiple ways, with some viewers considering "the activities and their graphic portrayal as intrinsic to the film and a device which effectively heightens the horror", while other viewers "see their inclusion as gratuitous and deeply disturbing". ${ }^{130}$ In terms of viewing context, Wrightson argued that there were "no relevant issues", although she did not make any specific comments about the nature of the film's intended exhibition. ${ }^{131}$ Based on the original application for classification, there was only a single print of the film and the return for this print was an Auckland cinema, suggesting that a limited run at this cinema was intended. ${ }^{132}$ Unlike the ban of Henry, the ban on Salò was not appealed, most likely for financial

\footnotetext{
125 Ibid.

126 Ibid.

127 Ibid.

128 Ibid.

129 Ibid.

130 Ibid.

131 Ibid.

132 Ibid.
} 
reasons if the intended exhibition was so limited. There was also no attempt to submit the film to the Video Recordings Authority for classification. However, the film was passed uncut in 1997 under the new Films, Videos and Publications Classification Act 1993, albeit restricted to screenings at the 1997 International Film Festival and tertiary studies, with an R18 rating. In 2001, it was passed uncut on DVD with no such restrictions on distribution, again with an R18 certificate. Notably, the film was passed uncut for the very same reason that Wrightson had rejected the possibility of passing a cut version. The Summary of the Reasons for Decision notes:

In that the publication depicts acts involving the infliction of cruelty and serious physical harm, sexual violence, and sexual and physical conduct of a highly degrading nature, and shows the perpetrators deriving sexual pleasure from undertaking these activities, the publication does contain material relevant to $s 3(3)$. After consideration and consultation, it is felt that excisions would distort and dilute the message that the film carries, as well as removing the context for what occurs in the film. ${ }^{133}$

This new decision also saw the "art vs exploitation" pendulum swing back in Salò's favour, with the OFLC also noting:

The Classification Office notes the merit of the publication and believes that it does have sufficient artistic, historical and cultural merit to warrant it being made available. It is unlikely to appeal to anyone without a background knowledge of either de Sade, Pasolini, or Fascism, and is therefore likely to be viewed by a limited number of people. ${ }^{134}$

\section{Salò, or the 120 Days of Sodom - analysis}

As with the case of Henry, the censorship of Salò in New Zealand centred around the issue of the perceived tone of the film, rather than purely its content, as well as contentious terminology such as "gratuitous". Like Henry, Salò is a difficult film to "pin down" and ascribe a particular meaning to. As Hantke notes about Henry, the film's narrative "is surprisingly difficult to summarize in a coherent fashion" 135 , and similarly,

\footnotetext{
133 Office of Film and Literature Classification online database, http://www.classificationoffice.govt.nz/DDA/Pages/Screens/DDA/WelcomePage.aspx. 134 Ibid. 135 Hantke, 32.
} 
Dalton and Schubert state of Salò that "[t]he film resists neat summaries"136, suggesting that in both cases the films are open to multiple contrasting interpretations, and the experience of watching them will vary significantly depending on the viewer. Indeed, Dalton and Schubert further argue that Salò "deeply polarises people", and that "[s]ome champion it as an art cinema masterpiece", while others see it as "a cinematic abomination". ${ }^{137}$

While Wrightson evidently saw greater artistic merit in Salò than in Henry, its artistic importance was not seen as sufficient to outweigh other factors which led to it being banned. However, similarly to the cases of Last Tango in Paris and Henry: Portrait of a Serial Killer, the point at which artistic merit would be seen to outweigh other considerations leading to a ban is not clearly defined, and depends both on which aspects of the film text itself are emphasised, and how particular factors external to the text are weighed. As Simon Hobbs notes, without external context such as an understanding of Pasolini's intent for the film to be a metaphor for fascism, it is possible to simply view Salò as gratuitous and exploitative because of the graphic nature of its content:

Significantly, in order for the film's explicitness to be sanctioned within an art film framework, Pasolini's allegorical explanation must be understood and accepted as justification for the images on screen. Without this explanation, the film becomes devoid of intellectual significance and exists merely as a series of extreme and transgressive images. ${ }^{138}$

Church suggests that the viewer's prior knowledge when viewing the film affects the way in which it is perceived, with "culturally activated readers" likely to "privilege certain textual qualities over others". ${ }^{139}$ There is a notable difference between Jane Wrightson's decision to ban the film in in 1993 and the decision to pass the film uncut in 2001, with the latter decision based on the film's artistic merit outweighing other factors, rather than the other way round in the case of Wrightson's ban.

In terms of the film's perceived impact, Wrightson focused on the potential harm that might be caused by those seen to be attracted to the film for reasons other than its

\footnotetext{
136 Dalton and Schubert, 59.

137 Ibid., 60.

138 Hobbs.

139 David Church, "Of Manias, Shit, and Blood: The Reception of Salò as a 'Sick Film'," Participations: Journal of Audience \& Reception Studies 6, no. 2 (2009): 358.
} 
political message and artistic merit. In doing so, she created an imagined audience of viewers likely to be attracted to the film for the "wrong" reasons. In his discussion of the reception of Salò as a "sick film", Church notes that the film's graphic nature has attracted audiences who are not primarily interested in its political message or its position as a work of an acclaimed director:

Yet, some of the same 'transgressive' qualities that contributed to the film's initial and continuing notoriety among viewers with high levels of what Pierre Bourdieu terms 'cultural capital' (i.e., 'knowledge that is accumulated through upbringing and education which confers social status') have allowed it to also find favor among horror audiences more attuned to low culture, specifically those privileging its shocking and viscerally affective depictions of sadism, coprophagia, sexual violence, mutilation, and murder. ${ }^{140}$

The 2001 decision to pass the film uncut focused on a different imagined audience, arguing that those who viewed the film would most likely be interested in Pasolini and fascism - the viewers with "cultural capital" rather than those primarily interested in the film's graphic content alone.

As with Henry, the idea of whether the film is "gratuitous" is extremely debatable Wrightson noted that some viewers found the depictions of sexual torture "gratuitous and deeply disturbing", while others considered them central to the film's message. Wrightson's decision to ban the film appears to reflect similar potentially contradictory reasoning to that of Henry, as she argues both that cuts to the film were not considered as they would "directly detract from the issues" Pasolini explores, yet also that because of the film's graphic nature, the "fascist metaphor arguably seems lost" in the explicit sexual depictions. However, if cutting material from the film can be seen to compromise the film's message, it is arguably by definition not gratuitous.

\section{The role of the Video Recordings Authority, 1990-1994}

Due to the closure of the "loophole" surrounding video classification by the passage of the Video Recordings Amendment Act 1990, pornographic video tapes were no longer submitted to the Chief Censor, so their classification became the almost exclusive

140 Ibid., 341. 
preserve of the Video Recordings Authority. ${ }^{141}$ The VRA continued to cut or ban such films for portrayals of sexual violence or coercive sex, but also for other non-sexual factors. The new head of the VRA was Lois Hutchinson, a former nurse who had been working as a video examiner since 1987. ${ }^{142}$ This previous profession seemed to inform her views on censorship. In a newspaper profile in 1991, Hutchinson expressed concern that the portrayal of nurses in pornographic videos "as sexually available, promiscuous bimbos undermines [their] credibility". ${ }^{143}$ Wet and Wild required cuts "to remove the theme of nurses depicted as objects of sexual desire who will administer to the carnal needs of patient and doctor"144, and Electric Blue 37 was cut "to remove dialogue which serves to denigrate nurses as a professional body". ${ }^{145}$. In another case, the video Twin Freaks, a pornographic parody of the television series Twin Peaks, had to have its title altered as "the video features a dwarf" and thus "[t]he use of the term 'freak' is seen to be obvious and deliberate, and is considered to be demeaning, if not denigratory, to the condition of dwarfism". ${ }^{146}$ However, in one particular aspect of sexually explicit videos, the VRA displayed what can be characterised as a blatantly contradictory stance, and a shift to classification based on manifest content alone rather than a broader consideration of context and the video recording as a whole. This is the case of pornographic films which included urination in a sexual context. Prior to the Video Recordings Amendment Act 1990, both the Chief Censor and the Video Recordings Authority had passed as R18 pornographic videos depicting urination, and in 1991, the VRA passed the video Pure Pissing Pleasure uncut with an R18 certificate, arguing that it portrayed "a light-hearted display of urination activities in a sexual context", and while many people would find this offensive, it was "a recognised sexual preference" and there was "no distress or coercion evident". ${ }^{147}$ This was consistent with the view expressed by Lois Hutchinson in response to a complaint by Patricia Bartlett about this video being passed, Hutchinson noting that "[t]he Authority's position on 'urination' is always neutral", that "[t]he Authority will never say that 'urination' is never 'indecent' nor will it say that it is always 'conditionally indecent'.

\footnotetext{
141 The only other pornographic videos officially examined in New Zealand during this period were the final two decisions of the Video Recordings Board of Review.

142 North \& South, October 1990, 111.

143 The Dominion, 7 October 1991.

${ }_{144}$ ADNB 23134 Box 292 - Video Recordings Authority Classification and Excision Notices 1991

145 ADNB 23134 Box 293 - Video Recordings Authority Classification and Excision Notices 1991.

146 ADNB 23134 Box 306 - Video Recordings Authority Reasons for Decisions 1992-1993.

147 ADNB 23134 Box 304 - Video Recordings Authority Reasons for Decisions 1991-1992.
} 
Each instance must be tested", and that "[t]he Authority acknowledges that 'urination' is offensive to many persons but that does not give grounds to reject any video recording merely because urination is evident." 148 Several years later in 1994, Acting head of the Video Recordings Authority Libby Hogg maintained that this sort of approach was the one that the Authority continued to take:

The Authority does not operate using a "shopping list" of outlawed acts, rather, it is the manner (and context) of the depictions that is crucial. Therefore, it is not possible for me to provide you with a list of acts that are deemed Indecent. ${ }^{149}$

However, a decision several months earlier on the German pornographic video Mosenpower, which required the removal of trailers depicting urination, appears to directly contradict Libby Hogg's explanation of how the Authority made their decisions, focusing purely on particular manifest content as inherently "injurious" rather than looking at it in context. The Authority's written decision explained:

Urolagnia is considered by society to be an antisocial act. The focus on urination in the trailers, the deliberate nature of the depictions - for the most part male on female - the presentation of this activity as fun and as a normal part of sexual behaviour, when every indication is that in NZ society this is not the case, is of concern. The message that people want to be urinated upon in a sexual situation is injurious to the public good. ${ }^{150}$

As will be discussed shortly, such depictions were soon to be outlawed by the Films, Videos and Publications Act 1993, which had been passed but had not yet come into force, based on a recommendation of the Committee of Inquiry into Pornography. It is arguable that perhaps such a decision was made in anticipation of the upcoming legislative regime, rather than operating under the one which was soon to come to an end.

The Video Recordings Authority also dealt with a number of non-pornographic films, although during this period they represented the minority of the material which they classified. However, the decision-making process was much more transparent, as the VRA began to issue detailed written decisions explaining their classifications, which was described as "at the initiative of the Video Recordings Authority" rather than being a legal requirement, and intended to "enhance the Video Recordings Authority's

\footnotetext{
148 ADNB 23137 Box 4 - Society for the Promotion of Community Standards 1987-1993.

149 ADNB 23136 Box 5 - Publicity/Public Contact/Education - Inquiries and Complaints 1993-1994.

150 ADNB 23134 Box 307 - Video Recordings Authority Reasons for Decisions 1993-1994.
} 
decision-making process and to illustrate the reasons behind the Authority's determination for each particular video recording". ${ }^{151}$ These written decisions often reveal a rather idiosyncratic approach to the concept of what is considered "injurious to the public good", in contrast with that of the Chief Censor's office. The 1970s Hammer Horror film To the Devil a Daughter (1976) was given an R18 classification "[g]iven current concerns about reported increases in satanic interest among teenagers". ${ }^{152}$ In the decision for the film Deadline, it is noted that "[t]his video recording presents as a "video nasty"', although the term is not defined in any way. ${ }^{153}$ The decision for the film Video Murders (1988) demonstrates a greater concern for the video's cover art which "profoundly exaggerates the film's content" than for the content of the film, although there is also mention of concern over "the manner in which the title appears" in the video itself, as the "colourful, playful lettering [is] suggestive of fun times ahead" and this "could be seen as trivializing the subject of sexual violence and confirming its value as entertainment". ${ }^{154}$ The serial killer film Dying Time (1990) is described as having violence which "though gratuitous, is not lingered upon", which would seem to be a somewhat contradictory statement. ${ }^{155}$

However, some general points can still be made about the operations of the VRA. One of these, which is consistent with decisions made during the first few years of the VRA's operation, is the attitude to perceived realism in the videos being examined, with films seen as more "honest" viewed more positively. This was not a perception of cinematic "realism" in the sense of the internal logic of the films, when "different constructed realities" come across as "full and apt and believable" in the context of the individual film, but the idea that "filmic material can sensibly be measured indexically, against the perceivable physical "reality" of the everyday world that film ostensibly depicts". ${ }^{156}$ Anything that deviated from portraying the external "reality" understood by the VRA examiners was viewed in a negative manner. For example, the film Rush, which depicts undercover police trying to expose a drug-dealing ring, is described as using this theme "as a device to enable the filmmaker to deal honestly with the issues

\footnotetext{
${ }_{151}$ ADNB 23134 Box 304 - Video Recordings Authority Reasons for Decisions 1991-1992.

152 ADNB 23134 Box 305 - Video Recordings Authority Reasons for Decisions 1992.

153 ADNB 23134 Box 304 - Video Recordings Authority Reasons for Decisions 1991-1992.

154 ADNB 23134 Box 305 - Video Recordings Authority Reasons for Decisions 1992.

155 ADNB 23134 Box 306 - Video Recordings Authority Reasons for Decisions 1992-1993.

156 Murray Pomerance, The Eyes Have It: Cinema and the Reality Effect (New Brunswick: Rutgers University Press, 2013), 14, 15.
} 
involved" and to "create an authentic, thought provoking picture of the circumstances, rather than exploitation of the subject matter". ${ }^{157}$ In contrast, in the decision on Wild Orchid 2, the VRA expressed concern over the film's perceived lack of "honest" and accurate portrayals of certain material:

Throughout the feature, prostitution is generally presented as sexually enjoyable for (established) prostitutes, and marriage is presented largely as sexually unfulfilling for the male spouse. These can be seen as hackneyed myths - with little basis in reality - which serve to reinforce potentially negative stereotyping already flourishing in society. ${ }^{158}$

A particularly notable element of these written decisions is their often extremely judgmental tone regarding the perceived quality of films, although it is not clear how far this affected the decision-making process. Sometimes this went beyond the specifics of the films themselves to register concerns about aspects of the home video market. For example, in their decision on Showdown in Little Tokyo the VRA noted:

The plentiful and readily available supply of violent video material such as this is, as always, of concern. They must surely reinforce casual, flippant, and unrealistic attitudes about violence amongst less discerning and mature members of the public. ${ }^{159}$

As this also suggests, the VRA still appeared to be guided by simplistic conceptions of media effects, as well as a vulnerable imagined audience who would be unable to understand such videos at the level which the VRA examiners believed they themselves did. In the case of the film Shocking Photographs, the written decision noted:

the Authority wishes to register concern about the trend towards packaging such material in a form that purports as a documentary - for entertainment - while hiding behind the legitimacy of the documentary. ${ }^{160}$

One of the most revealing decisions during this period was to pass with an R18 certificate the film Penitentiary III, which had previously been banned by the VRA, a ban upheld by the Video Recordings Board of Review. In passing the film, the VRA found "pro-social" messages in a film previously seen largely as either ambiguous or containing anti-social messages. ${ }^{161}$ In particular, the "portrayal of a black "little person"

\footnotetext{
157 ADNB 23134 Box 306 - Video Recordings Authority Reasons for Decisions 1992-1993. 158 lbid.

159 ADNB 23134 Box 305 - Video Recordings Authority Reasons for Decisions 1992.

160 ADNB 23134 Box 306 - Video Recordings Authority Reasons for Decisions 1992-1993.

161 ADNB 23134 Box 305 - Video Recordings Authority Reasons for Decisions 1992.
} 
(dwarf) as a semi-demented animal-type character" was noted as "previously of concern", but unlike in the case of the decisions to ban the film, this time the VRA found that this character "takes the role of mentor and trainer to the central protagonist", which was considered to be "a strong pro-social message". ${ }^{162}$ However, the film itself had not changed in the several years since its prior ban, suggesting that such reasoning was perhaps a "post-hoc" justification for passing a film that probably did not warrant a ban in the first place. As James March notes, "[w]e find meaning and merit in our actions after they are taken and the consequences are observed and interpreted"163, and in passing Penitentiary III, the VRA did note that "other video recordings that portray similar themes have entered the marketplace and are available for public viewing", apparently without obvious negative consequences. ${ }^{164}$

\section{A new censorship regime}

1993 saw the passage of the Films, Videos and Publications Classifications Act, which had its origins in the Committee of Inquiry of 1988. Wrightson considered her tenure as Chief Censor as "in effect a holding pattern", as this legislation was in the process of being put together when she first took the job in 1991.165 This legislation brought together censorship of film, video and other publications under one single authority, but rather than simply being a consolidation of censorship legislation, it can also be seen as a tightening of censorship restrictions. The idea of a "shopping list" of banned material had long been supported by the likes of the Society for the Promotion of Community Standards, but opposed by censors themselves including Wrightson, and while previous film and video censorship legislation had not included such a list, the 1993 Act did, limiting the ability for censors to use discretion and consider context in certain cases. Section 3 of the Act was entitled "Meaning of objectionable", and as well

\footnotetext{
162 Ibid.

163 James March, "Bounded Rationality, Ambiguity, and the Engineering of Choice." In Rational Choice, edited by Jon Elster (Oxford: Basil Blackwell, 1986), 160.

${ }^{164}$ ADNB 23134 Box 305 - Video Recordings Authority Reasons for Decisions 1992.

165 Interview with Jane Wrightson.
} 
as including the principle of "injurious to the public good", listed specific types of material to be banned under the Act:

A publication shall be deemed to be objectionable for the purposes of this Act if the publication promotes or supports, or tends to promote or support,-

(a) the exploitation of children, or young persons, or both, for sexual purposes; or

(b) the use of violence or coercion to compel any person to participate in, or submit to, sexual conduct; or

(c) sexual conduct with or upon the body of a dead person; or

(d) the use of urine or excrement in association with degrading or dehumanising conduct or sexual conduct; or

(e) bestiality; or

(f) acts of torture or the infliction of extreme violence or extreme cruelty. ${ }^{166}$

The new law also made possession of material considered "objectionable" illegal when personal possession had previously been allowed, as long as it was not being publicly distributed. This led to another amnesty allowing people to surrender such material without prosecution, but unlike in the case of the 1990 amnesty, Patricia Bartlett did this time give up her "fabled collection" of pornography. ${ }^{167}$

As a consolidation of existing censorship legislation, this new Act represented the end of an era in New Zealand censorship history. While some films such as Gaspar Noe's Irreversible (2002) would be passed for cinema viewing only, the distinction between public viewing and private viewing became irrelevant in the vast majority of censorship decisions, with most classifications applying to both contexts. The wide definition of what constitutes a "publication" under the Act has led to the classification of items as diverse as vehicles and a T-shirt. However, the continued separation of broadcasting such as television and radio under different legislation has led to confusion in recent years with the rise of online streaming of video content, and calls for further consolidation of censorship legislation similar to that which occurred in 1993 in order to deal with this confusion.

\footnotetext{
166 Films, Videos and Publications Act 1993, Section 3(2).

167 Sunday Times, 29 August 1993.
} 


\section{Chapter summary}

The period from 1990 to 1994, under new Chief Censor Jane Wrightson, saw some significant changes in film censorship in comparison to the tenure of her predecessor Arthur Everard. Some of these were explicitly stated by Wrightson herself, such as a desire to rebuild relationships with lobby groups, and a more conservative approach to the classification of cinematic violence. However, the two most controversial decisions made during Wrightson's tenure, the bans on Henry: Portrait of a Serial Killer and Salò, or the 120 Days of Sodom, reveal other differences in the way in which censorship decisions were explained and legitimised. These included a much more explicit focus on the issue of perceived artistic merit, and how far this could be seen to outweigh other factors in the decision-making process; a greater emphasis on formal consultations and the legitimation of particular discourses as a result of these consultations; and a concern that both films might attract audiences more interested in their graphic portrayals of violence and (in the case of Salò) sexual content, rather than any more serious messages which they could be seen to be expressing. The decisions also illustrate the difficulty of classifying films without a single clear and overt meaning - both Henry and Salò are open to many different interpretations, and their polarising nature meant that any attempt to "fix" a meaning on them through a particular censorship classification was always going to be contentious and debatable. Indeed, reflecting back on her decision on Salò, Wrightson suggested that "in hindsight...was I right? Probably not", but also noted that such decisions were "very difficult to make" and "of their time". ${ }^{168}$ However, there was still a significant degree of continuity, as film censorship was still a very detailed and carefully considered process, with an avoidance of decision-making based on simplistic reasoning. Again, this contrasted rather strongly with the way in which the Video Recordings Authority made its decisions. While they were much less enthusiastic in their cutting of nonpornographic videos, their decisions still demonstrated a simplistic conception of media effects; a reliance on an imagined audience of vulnerable viewers seen to be unable to comprehend particular videos at the same level as the VRA's examiners; and a concern over the lack of perceived "honesty" and "realism" in some videos.

168 Interview with Jane Wrightson. 
However, the Films, Videos and Publications Classification Act of 1993 was to render such differences irrelevant, bringing film and video classification together under one piece of legislation and one censorship body. 


\section{Conclusion}

\section{Chapter overview}

This chapter will outline the empirical and theoretical contribution which this thesis has made to the academic literature about censorship in general, and film and video censorship in particular. In outlining the theoretical contribution, I will focus on the key themes which have arisen from my research, and how far they align with or contradict particular theoretical perspectives on censorship and media policy. In doing so, this addresses the two research questions outlined at the start of the thesis:

1. What continuities and changes were there in the way in which film and video censorship was practiced and rationalised in New Zealand during the period from 1976 to 1994 ?

2. How can such continuities and changes be explained in terms of individual agency, institutional pressures, legal requirements, and other factors?

\section{Empirical contributions to academic literature on censorship}

Purely from an empirical perspective, the detailed archival research in this thesis represents a significant contribution to the literature about film and video censorship on several levels. In the context of the literature on censorship in New Zealand, it expands upon the existing coverage using previously untapped archival source material, providing a more detailed narrative of film and video censorship in the period from 1976 to 1994 than has previously been written. In focusing on archival material from the censors themselves as my main source of data, this thesis also provides a more detailed account of the way individual censorship decisions were made and rationalised in the case of some of the most contentious and contested films in New Zealand censorship history. In terms of the individual films themselves, many of them have been controversial around the world, and have faced problems with censorship 
outside New Zealand - their censorship history is a significant part of their reception history as a whole. In focusing on such films in a New Zealand context, I have added to the literature on the censorship history and reception of such films, providing an insight into the ways in which they were received in New Zealand in comparison to other countries. This thesis also provides a point of comparison with censorship in other countries during the period from the late 1970s to the early 1990s, including how New Zealand dealt with the issue of home video censorship in comparison with the "video nasties" moral panic in the United Kingdom. In the case of the UK "video nasties", which have been the subject of a significant amount of academic study, this thesis also provides evidence of a direct link to that historical narrative. The Society for the Promotion of Community Standards brought Chief Inspector Peter Kruger, who had been involved with the prosecution of "video nasties" for obscenity in the UK, to New Zealand to show a compilation of material from some of these films to try and persuade MPs to pass restrictive video censorship legislation - with rather different results than in the UK.

\section{An institutionalist political economy approach}

The main theoretical approach of this thesis has been that of institutional political economy, therefore a major focus of my research has been the way in which key actors in the censorship process worked within an institutional context. As B. Guy Peters notes, while there are various approaches to institutionalism, "[t]he most important argument binding these various approaches is that structures - however defined - do matter"1. Institutional theorists argue that individuals within institutions are constrained to some degree by these structures, but that these institutional actors still have a degree of individual agency. Some approaches stress that the "instrument through which constraint on the individual is exercised" is through clear rules, whereas others suggest that it is through less clearly defined "values and norms". ${ }^{2}$ In either case,

\footnotetext{
${ }^{1}$ B. Guy Peters, "Institutional theory: problems and prospects." In Debating institutionalism, edited by Jon Pierre, B. Guy Peters and Gerry Stoker (Manchester: Manchester University Press, 2008), 5. 2 B. Guy Peters, Institutional Theory in Political Science: The 'New Institutionalism' (London: Pinter, 1999), 141-142.
} 
individuals do have room to manoeuvre, but within certain boundaries that constrain their decision-making. The case studies examined in this thesis are of films that were the most contentious in censorship terms, and thus usefully demonstrate the way in which censorship agency was expressed and constrained, as well as clearly demonstrating change over time. A study based on films where the censorship classification is not in any way significantly contested (such as G-rated children's films, or the most extreme of pornographic material) would not have provided such valuable insights into the censorship process. In the examples I have studied, censorship is a "messy" process, and far from a purely legalistic and technical one - as Des Freedman notes, media policy practice, or "the systematic attempt to foster certain types of media structure and behaviour and to suppress alternative modes of structure and behaviour, is a deeply political phenomenon". ${ }^{3}$ A political economy approach, which focuses upon "the relationships of power that are involved in the production, distribution, and consumption of media and communication resources within a wider social context"4, emphasises the contest for power and discursive legitimacy that marks the censorship process. While in the case of New Zealand during this period, the Chief Censor did have the ultimate say on individual censorship decisions, there was much more going on than just what was specified in the legislation. As Freedman suggests, "media content is subject to a barrage of both formal and informal pressure from governments, judges, political parties, pressure groups and corporations" 5 , and this was certainly true for film and video censorship in New Zealand from 1976 to 1994.

\section{Typology of censorship rationalisation}

One of the most significant aspects of the way censorship decisions were made and rationalised in New Zealand during the period which I have examined is that much of the censorship process was situated in a discursive space outside of the manifest content of the films themselves, and in other areas of contested discursive legitimacy.

\footnotetext{
${ }^{3}$ Des Freedman, The Politics of Media Policy (Cambridge: Polity Press, 2008), 1.

4 Janet Wasko, "The Political Economy of Communications." In Mass Communication Research Methods: Volume 2, edited by Anders Hansen (Los Angeles: Sage, 2008), 21.

${ }^{5}$ Freedman, 122.
} 
This is one of the most significant findings of this thesis, and the development of a typology of modes of censorship decision-making rationalisation has provided a way of addressing the issue of change and continuity in censorship practice during the period covered in this thesis. These modes of rationalisation have formed the basis of my analysis of each of my case studies of censorship of individual films, and the main rationalisations for each of these case studies are identified on the following timeline.

1. Opinions regarding the nature of the perceived impact of specific films, or cinema in general, on audiences

2. The viewing context of a film, including whether a film is viewed in a cinema or on home video, and the restriction of films to certain types of screenings such as for film festivals or film societies

3. The views of lobby groups such as the Society for the Promotion for Community Standards, and the perceived reaction they might have to censorship decisions

4. Judgements about the quality and cultural importance of particular films

5. Judgements about the tone of particular films and how they present certain content, rather than simply the content itself

6. Appeals to normative standards, such as whether a film would be acceptable to what were perceived to be "community standards"

7. Appeals to third party authorities, such as representatives of certain institutions like the police, members of the general public who were consulted regarding certain films, and academic research regarding films and their impact on audiences

8. The wider social context surrounding the release or potential release of a film

9. The perceived realism of any particular film, including how accurately it is seen as portraying certain aspects of society

10. The distinction between what is considered "injurious to the public good" and what is considered potentially "offensive" to much of the public, but not "injurious"

11. The use of language that is contentious and unclearly defined, such as "gratuitous", in the justification of censorship decisions 


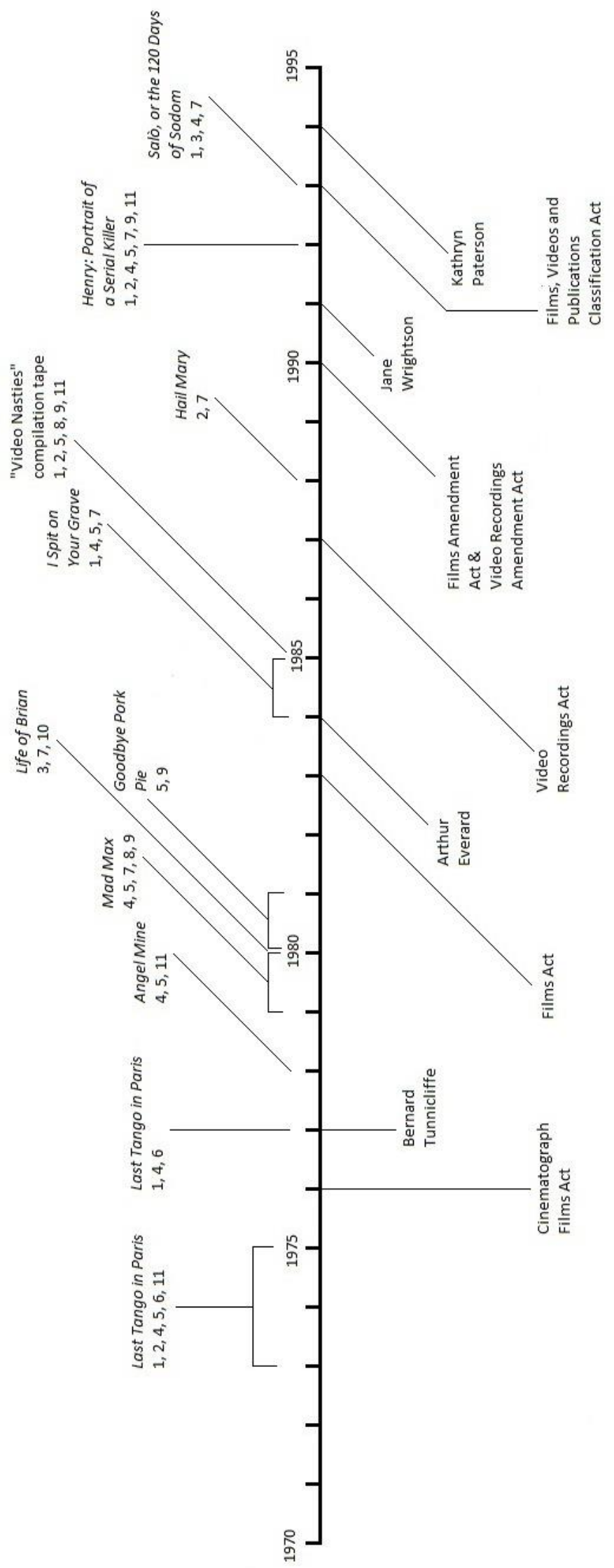

Figure 5: Timeline of censorship case studies, indicating modes of rationalisation of decisions. 
The way in which these rationalisations are weighed up by the censors, and which are emphasised to the greatest degree, significantly affects the final censorship decision. In some cases, emphasising different factors can result in different decisions on the same film - such as the Chief Censor banning Henry: Portrait of a Serial Killer partly because of a lack of perceived artistic merit, and the Video Recordings Authority passing it with an R18 classification (albeit in a cut form) with their written decision emphasising that they felt it did have significant merit. In focusing on elements such as the tone of a film and its perceived realism, censorship can become an act of textual analysis, with the censor in the position of fixing a particular meaning on a film in order to make a decision. This tends to be much more problematic in the case of films where the meaning is unclear and ambiguous, such as Henry and Salò, and can lead to decisions that are contentious and open to critique and possibly legal appeals. In the case of some films on video examined by the Video Recordings Authority, their ambiguous nature was seen as a justification for a ban, as the VRA believed that some viewers might take the "wrong" message from the films.

\section{Change and continuity in censorship practice, 1976-1994}

This thesis has demonstrated that while change within censorship institutions does occur, it tends not to be abrupt or drastic. In her interview, Jane Wrightson suggested that "not much changes in censorship", and this thesis has demonstrated that there is certainly a degree of truth to this statement. ${ }^{6}$ While there were several legislative changes in the period from 1976 to 1994, this was not the major driver for changes in censorship practice, which was instead largely the result of subtle shifts in "values and norms" rather than changes in legislative rules.

As Janet Wasko notes, when undertaking historical analysis of the political economy of media, "it is essential to document change as well as continuity" , and both are evident in the period which I have examined. During the period examined in this thesis,

\footnotetext{
${ }^{6}$ Interview with Jane Wrightson.

7 Wasko, 9.
} 
there were three different Chief Censors, and two changes in government, and a number of different Ministers of Internal Affairs. However, as B. Guy Peters argues, institutional theories suggest that "institutions create greater regularity in individual behaviour than would be found without the existence of those institutions", 8 and "structures persist while individual members of those structures come and go". 9 Thus, it is perhaps unsurprising that despite significant changes in government and in the Chief Censor's office, there was a high degree of continuity and consistency in the way in which film censorship was carried out and discussed. Throughout the period from 1976 to 1994, both censors and government Ministers demonstrated an understanding of media effects which recognised that the influence of media is a complex issue, and that many other factors influence human behaviour - in direct contrast with the views of pressure groups such as the Society for the Promotion of Community Standards which tended to take a much more simplistic approach. Both the censors and Ministers were careful not to overestimate the importance of the views of such voices in favour of stricter censorship in comparison to the views of the wider public, and generally took a careful, considered approach which was not swayed by strongly expressed views such as those of the SPCS. In terms of specific censorship decisions, my timeline of key censorship case studies illustrates some of the significant consistencies in the way these decisions were rationalised. When films were banned outright, there tended to be a greater number of different modes of rationalisation regarding the decision, suggesting that there was a desire to present the decision as more secure and legitimate as banning a film in a democratic country tends to be contentious. For example, Jane Wrightson made a point of providing an extremely detailed written decision when Henry: Portrait of a Serial Killer was banned, while noting in her submission to the Films Censorship Board of Review that she was "not statutorily required" to do so, but that the "unusual nature of the decision" led her to outline the reasons for it in some detail. ${ }^{10}$ However, it is not necessarily just the fact that a film has been banned that leads to a greater effort to legitimate a censorship decision through many different rationales, but how contentious the decision is and to

\footnotetext{
${ }^{8}$ B. Guy Peters, Institutional Theory in Political Science: The 'New Institutionalism' (London: Pinter, 1999), 144.

${ }^{9}$ B. Guy Peters, "Institutional theory: problems and prospects." In Debating institutionalism, edited by Jon Pierre, B. Guy Peters and Gerry Stoker (Manchester: Manchester University Press, 2008), 6. ${ }^{10}$ ADNB 23136 Box 6 - Controversial/Rejected Films - Henry Portrait of a Serial Killer 1991-1993.
} 
what extent the censors are placed in a position of having to justify it. For example, when Arthur Everard passed I Spit on Your Grave uncut, this resulted in a significant negative response from groups such as the Society for the Promotion of Community Standards, and he outlined a variety of different justifications for his decision in his extremely detailed correspondence regarding the film.

Also present throughout the whole 1976 to 1994 period were appeals to third party authorities to support censorship decisions, which included consultations with members of the public and experts on certain subjects and, particularly in the case of Arthur Everard, reference to academic research, suggesting a desire by all the censors in this period to demonstrate recognition of other voices outside those of the censor's office itself. Both Arthur Everard and Jane Wrightson expressed such views when reflecting back on their time as censors in their interviews, Everard arguing that if there was research that suggested that sexually explicit material involving consenting adults was not harmful, "how could we ignore it?"11, and Wrightson suggesting that the consultations she undertook on certain films helped "to make sure that when you're sitting in dark rooms in Wellington, you're not just talking amongst yourselves". ${ }^{12}$ Another rationalisation used throughout the period by all three Chief Censors was that of reference to the tone of a film, or the way in which it presents certain types of content, rather than merely the content itself. This suggests a consistent effort to focus on films on an individual, case-by-case basis, assessing them as a whole, rather than simply focusing on certain aspects of their manifest content.

However, the period from 1976 to 1994 was also one of significant changes in censorship discourse and practices, although these were largely subtle shifts over time rather than abrupt ones. Despite the superficial appearance of a drastic shift towards greater liberalisation of censorship once Arthur Everard took over from Bernard Tunnicliffe as Chief Censor, as claimed by groups such as Women Against Pornography and the Society for the Promotion of Community Standards, Everard took a careful and cautious approach to censorship which did not initially represent a major break from the way the Chief Censor's office operated under his predecessor. For example, he did not initially pass sexually explicit videos uncut, and would only eventually do so after careful consideration of evidence of any potential harm they

\footnotetext{
11 Interview with Arthur Everard.

12 Interview with Jane Wrightson.
} 
might cause. Moreover, he still cut other films for violent content during the early part of his tenure. Indeed, Everard himself tried to stress in his correspondence that his approach to censorship was not as liberal as his detractors were suggesting. However, there is evidence of a trend towards greater liberalisation of film censorship under Everard. Under Tunnicliffe, low-budget exploitation films were sometimes banned with clearly negative value judgments about them evident in the daybooks; such language was not evident in the daybooks during Everard's tenure, and Everard made clear the distinction between his personal views on a film and his views as a censor. Under Wrightson, there was a shift back towards a somewhat stricter and more conservative approach - indeed, Wrightson herself acknowledged this at the time - but this was a subtle shift rather than a dramatic departure from the way in which the Chief Censor's office had operated under Everard. The timeline of censorship decisions also illustrates some notable changes in the way decisions were rationalised between 1976 and 1994. For example, issues of the perceived quality and cultural importance of films were more significant in Tunnicliffe and Wrightson's eras than in Everard's - indeed, Everard made a clear distinction in the case of some films which he passed, such as Tobe Hooper's The Texas Chain Saw Massacre, between his assessment of the film from a censorship point of view and his own personal distaste for the film, making it clear that he did not consider the latter to be a part of the decision-making process. The issue of perceived cinematic realism was appealed to as a rationalisation for decision-making throughout the whole period, although this was applied differently for different films, with both perceived realism and a lack of perceived realism seen as grounds for a greater level of restriction at different times. Some rationalisations were rarely used and were specific to individual decisions. For example, Mad Max was the only film where the specifics of the wider social context of the time was a major factor in the decision, although the ban on the "video nasties" compilation tape does appear to have been partly influenced by wider debates around home video censorship occurring in New Zealand and the United Kingdom.

However, change was not only evident in the rationalisation and decision-making process of the censors themselves, but in other aspects of the wider censorship process. While groups such as the Society for the Promotion of Community Standards appeared to change little in their beliefs and their staunch opposition to what they perceived as more liberalised censorship, they did change the ways in which they 
engaged with the censorship process itself. While letters and petitions were a common approach throughout the period, there was a move to more direct legal measures such as the court cases around the classification of Jean-Luc Godard's Hail Mary and the two pornographic videos Pretty as You Feel and Inches. The Society for the Promotion of Community Standards also used new legal means to attempt to forward their aims for stricter film and video censorship, such as submitting pornographic videos to the Video Recordings Authority in an effort to get them banned, and using a new amendment to the 1983 Films Act to get the film Sacred Sex referred to the Films Censorship Board of Review.

In the case of video censorship, there were more significant changes evident than for film censorship, and a greater degree of inconsistency in the way in which the process of censorship operated. While film censorship had long been established in New Zealand, video censorship had lacked clearly defined institutional practices, routines and norms, and before the 1987 Video Recordings Act, had been carried out in a variety of ways by different institutions such as the Chief Censor, Customs, and the video industry itself. The formation of the Video Recordings Authority in 1987 was followed by a period of confusion and inconsistent rationalisation of censorship decision-making, suggesting that a new censorship institution with rules in the form of legislation, but lacking established values and norms, is likely to demonstrate less consistency in individual behaviour and fewer clear constraints on such behaviour.

\section{Censorship and objectivity}

This thesis also highlights the tension between the way in which censorship decisions are often presented as objective and free from individual bias, and the far more subjective and "messy" way in which these decisions are actually undertaken and rationalised. During their tenures, the three Chief Censors during the period of my study presented their decisions as being objective, but hindsight seems to create a different perspective. In retrospect, censors seem much more willing to acknowledge the degree of subjectivity in their decision-making process than when they are still engaged in the censorship process. In their interviews, Arthur Everard and Jane Wrightson were more willing to acknowledge the degree of subjectivity in their 
decisions than in their correspondence and other writings from their time as censors. Similarly, then current Chief Censor Andrew Jack suggested in his interview that he considered that the "the law is very prescriptive" and is "heavily prescribed by law so it doesn't give you a lot of wiggle room", arguing that censorship is an objective process based on applying the law rather than on subjective value judgements. ${ }^{13}$ It is also arguable how far any such decision can ever be genuinely "objective" when it goes beyond the manifest content of a film alone, and into more nebulous areas such as a film's perceived realism, its perceived tone (the way in which it presents its content, rather than simply the content itself), and views on issues such as the viewing context and media effects. The censor's decision to focus on certain discursive areas outside the manifest content can lead to different decisions on the same film. For example, Jane Wrightson downplaying the artistic significance of Pasolini's Salò in comparison to concerns about the potential impact of its extreme content, in contrast to the decision to pass the film a few years later where its artistic merit was seen to outweigh other considerations that might have led to a ban. In some cases, the language used to explain and rationalise censorship decisions betrays a degree of subjectivity at odds with the censor's claims of objectivity and lack of individual bias, particularly terms such as "gratuitous" and "exploitative", which represent ill-defined value judgments rather than an assessment of a film's likelihood to be "injurious to the public good". Indeed, the concept of "injurious to the public good", while sometimes presented as more "objective" than other censorship measures such as "offence" or "indecency", is itself prone to subjective interpretation as it is difficult to define what "injurious" actually means. In his interview, Arthur Everard suggested that defining "injurious" was somewhat "like judges trying to define 'reasonable' - they don't, because they can't" 14 , and as Julian Petley notes in discussing the UK context, the idea of 'harm' is interpreted in such a broad way as inevitably to involve the censors in what are essentially moral judgements". 15

\footnotetext{
13 Interview with Andrew Jack.

${ }^{14}$ Interview with Arthur Everard.

${ }^{15}$ Julian Petley, Film and Video Censorship in Contemporary Britain (Edinburgh: Edinburgh University Press, 2011), 96.
} 


\section{Censorship as a process}

The case studies of censorship which I have examined support Annette Kuhn's conception of censorship as not being "a one-way street, something that is done to films"16, but instead "is a matter of relations... a process, not an object", based around "the interactions between the various institutional practices involved....the relations between them, the ensemble of practices condensed in any one instance of film censorship". ${ }^{17}$ In these examples, censorship is not a not a single act of classifying or banning a film, but something that occurs at all stages of a film's production and distribution. The justification and rationalisation of censorship decisions after they have been made is often a significant part of the process, and in many cases is the result of engagement in the process by other key actors such as pressure groups. However, the case studies examined in this thesis demonstrate that while power is deployed by different groups and individuals in both formal and informal manners, this power is distributed unevenly, and at least in the context examined in this thesis, is weighted more towards state power in the form of the official censors and politicians. This suggests that in the continuum of defining censorship identified in the introduction, from something unavoidable and omnipresent at one end, and the unidirectional implementation of state power at one end, this thesis suggests a definition leaning more towards the latter, although recognising that it is not a simple process. Particularly significant is the way in which some discourses were given legitimacy while others were not - what Des Freedman describes as "ideological legitimation, a situation in which certain ideas are normalized and others are problematized". ${ }^{18}$ In the case of New Zealand between 1976 and 1994, pressure groups and those complaining about films without direct personal knowledge of their content were not afforded discursive legitimacy. Multiple Ministers in different governments supported the approach of the Chief Censor's Office and acknowledged their independence and professionalism, recognising that the views represented by groups such as the SPCS did not represent those of the wider public as a whole. This contrasts quite strongly with other examples such as the "video nasties" scare in the UK during the same

\footnotetext{
${ }^{16}$ Annette Kuhn, Cinema, censorship, and sexuality, 1909-1925 (London: Routledge, 1988), 4.

17 Ibid., 127

18 Freedman, 3.
} 
period, where those campaigning for stricter censorship found their views gaining a significant amount of traction. In the UK, this was in part the result of the role of the tabloid press in fomenting moral panic, while in New Zealand, the media took a much less activist role in reporting on issues of censorship. While the Chief Censor's Office collected a large amount of material from newspapers and elsewhere on the subject of censorship, the media is given little mention in correspondence by censors, Ministers and others, and they sometimes tended to oversimplify the way in which the censorship process worked by presenting limited information about the rationale behind the censors' decisions. Therefore, by focusing on archival sources, this thesis provides a much richer and more detailed account of censorship than would have been possible with a focus on media sources.

The idea of the censorship process as a contest for discursive legitimacy can also be linked to the concept of policy-as-discourse, which Carol Bacchi describes in the following manner:

The premise behind a policy-as-discourse approach is that it is inappropriate to see governments as responding to 'problems' that exist 'out there' in the community. Rather 'problems' are 'created' or 'given shape' in the very policy proposals that are offered as 'responses'. ${ }^{19}$

Thus, while the views of politicians and censors were presented as the "natural" way of dealing with the issue of film and video censorship, this is not necessarily the case, and due to the imbalance of power, these views became the norm. As Freedman argues, media policy, including censorship policy, does not "emerge spontaneously from the logic of communication technologies", but is "deeply political" ${ }^{20}$

While censorship during the production stages was not a significant factor in the New Zealand censorship history of most of the films which I have examined, as the New Zealand market would not have been considered significant enough to actually affect the creative process, two New Zealand made films, Angel Mine and Goodbye Pork Pie, demonstrate the way in which censorship considerations can affect the creative process and how censorship is, as Judith Butler suggests, "not merely privative, but formative". ${ }^{21}$ However, this does vary depending on the nature of the individual film,

\footnotetext{
${ }^{19}$ Carol Bacchi, "Policy as Discourse: What does it mean? Where does it get us?" Discourse: studies in the cultural politics of education 21, no. 1 (2000): 48.

${ }^{20}$ Freedman, 1.

21 Judith Butler, Excitable speech: a politics of the performative (New York: Routledge, 1997), 133.
} 
and these two examples provide rather different case studies. In the case of Angel Mine, the potentially controversial content led to consideration by the filmmakers over whether material may need to be cut, and negotiations with the censorship authorities prior to formal classification. In the case of Goodbye Pork Pie, a much more mainstream and commercial film, there was never any issue that film would be cut or banned, but as a result of its overtly commercial nature, the aim was for a less restrictive censorship certificate that would allow the film to be available to a wide audience.

\section{The imagined audience}

One of the ways in which censors go about their decision-making process and rationalise their decisions is through the creation of an imagined audience for the material which they are examining. In the period covered in this thesis, this is less evident in cinema censorship than in video censorship under the VRA and VRBOR. There is little reference to the idea of an imagined audience by Tunnicliffe or Everard, although Wrightson did focus on an imagined audience to some degree in the censorship of Henry and Salò, implicitly rejecting the idea that the films would primarily be seen by more "educated" audiences who would arguably better understand the films, and instead conceiving of a wider, more general audience in choosing to ban both films. The VRA and VRBOR focused much more explicitly on an imagined audience which was seen to be vulnerable to the messages of films in a way that the censors themselves were not, leading to a more restrictive approach than the film censors. In doing so, the video censorship authorities emphasised an imagined audience that could be seen as a small minority when assessing the potential for "injury to the public good", and made decisions on that basis, in contrast with the film censors who often tended to implicitly base their decisions on how the wider public as a whole would view any particular film. This difference between film and video censorship also highlights differences between public and private space, and the way in which they were understood. Discourse from politicians both before and after the Video Recordings Act emphasised the idea of "consumer information" and less restrictive censorship for home video viewers, as the home was seen as a private 
space that should be less restricted than public spaces. However, when the Act was actually implemented by the Video Recordings Authority, they took a stricter approach than the film censor did, and considered home video audiences particularly vulnerable. New Zealand's current film and video censorship legislation has largely abandoned this distinction, with most films given a single classification that applies both for public exhibition and for private home viewing. However, there have been some cases where cinema censorship has been less restrictive than home video censorship, with films including Gaspar Noe's Irreversible (2002) and Franck Khalfoun's Maniac (2012) approved for cinema screenings only.

\section{Technological change and contemporary censorship}

One of the most notable technological developments during the period I have examined was the rise of home video as a significant way in which the public viewed films. As Martin Barker notes, new forms of media have often led to fears about their impact, with "early cinema, the 50s crime and horror comics, paperback novels, television, video nasties, [and] video games" all resulting in "the same litany of fears...endlessly rehearsed". ${ }^{22}$ The issue of video censorship during the 1980s raised questions of effectiveness and relevance of film censorship, as home video provided access to a wide range of films that would otherwise have been unavailable, in a manner less regulated than the cinema. However, in New Zealand, the impact of home video on actual censorship theory and practice was somewhat limited. When the Video Recordings Act was passed in 1987, it used existing film censorship classifications as the basis for much of the video classification, with only material at the higher end of likely censorship restrictions, or videos that had not been previously classified in film form, going before the Video Recordings Authority. What differences there were between video censorship and film censorship were arguably the result of the lack of clearly established normative criteria in a newly formed censorship institution, rather than a fundamentally different approach to classification of films on video. Indeed, there is little evidence that the Video Recordings Authority or the Video Recordings

\footnotetext{
${ }^{22}$ Martin Barker, “Sex, Violence and Videotape," Sight and Sound, 3.5 (1993), 11.
} 
Board of Review conceived of video spectatorship as something inherently different from cinema spectatorship, suggesting that as is often the case, censorship theory and practice struggled to adapt to significant new technologies. This continues to be an issue today. As Andrew Jack acknowledged in his interview, modern technology such as the internet creates significant issues regarding "how you actually go about restricting access". ${ }^{23}$

While this thesis examines a particular historical period, and focuses on film and video censorship rather than censorship of other types of media, it still has relevance beyond this historically specific context for censorship in general in a contemporary context. It is easy to suggest that film and video censorship in the present day is increasingly becoming an irrelevance. Indeed, as Daniel Hickin suggests, as "the barriers between cultures, ideas, and images are becoming increasingly blurred" by technology such as the internet, this suggests a future for censorship "in which the current national regulatory frameworks become redundant". ${ }^{24}$ However, if examining censorship as a wider process, rather than simply an act undertaken by an officially constituted body, it still occurs today, but in a different form. As Ben Wagner suggests, "coercive power over the Internet is dispersed to many different actors", rather than being concentrated in the hands of state censors. ${ }^{25}$ However, during the period from 1976 from 1994, such "coercive power" over film and video censorship was not restricted to only those formally identified as censors, but was a contest for discursive legitimacy among a variety of historical actors involving both formal and informal power. The way in which censorship legislation tends to lag behind changes in media technology is also a recurring historical theme. While in the 1980s, censorship legislation to deal with the rise of home video was slow to emerge, today the issue of online streaming of content is a current grey area with no clear legislative framework. This has been highlighted by the recent example of the Netflix series 13 Reasons Why. While Netflix initially used existing New Zealand censorship classifications, and had previously been submitting their content to the Office of Film, they no longer do so. As noted on the OFLC's website:

\footnotetext{
23 Interview with Andrew Jack.

24 Daniel Hickin, "How to Cope with the Death of Film Censorship," The Velvet Light Trap 63 (2009): 63.

${ }^{25}$ Ben Wagner, Global Free Expression - Governing the Boundaries of Internet Content (Springer, 2016), 4.
} 
The Government has determined that streaming services like Netflix do not need to submit their content in advance for classification. Netflix stopped submitting their content to the Classification Office in August 2016. Consequently we could not, as we have done in the past, classify this series before it was available and provide appropriate information on the risks for New Zealanders - particularly parents and teens. ${ }^{26}$

However, public concern about its content, particularly the portrayal of suicide, led to the OFLC using its power to call in the series for classification, eventually giving a newly created classification, RP18. The OFLC notes:

An RP18 classification means that someone under 18 years old must view the series with the supervision of a parent or guardian. A guardian could be a responsible adult (18 years and over), for example a family member or teacher who can provide guidance. ${ }^{27}$

As with home video in the 1980s, the question of the practicality of the enforcement of this rating has been raised as an issue. In a manner akin to the discourse around "consumer information" being a major part of home video censorship in the 1980s, the OFLC invoked similar language in response to a query from a member of the public:

Firstly, the classification is about informing the public - both adults and teens - about the potentially harmful and disturbing content in the series, and Netflix will be including the new RP18 classification and our detailed descriptive note on the show. It is otherwise up to parents/guardians to be aware if people under 18 are watching the show and to provide supervision. ${ }^{28}$

While technology may change, censorship in the present day remains a "give-andtake between contending parties"29, and the way it operates as a process of interaction between formal and informal institutions is something that is still worthy of investigation today. An examination of the processes, discourses and rationalisations involved in film and video censorship in New Zealand from 1976 to 1994 is thus not merely of historical interest, but provides a framework for understanding how similar dynamics continue to operate, both in New Zealand and elsewhere.

\footnotetext{
${ }^{26}$ Office of Film and Literature Classification website, http://www.classificationoffice.govt.nz/news/latest-news/media-release-13-reasons-why.html. $27 \mathrm{lbid}$.

${ }^{28}$ Office of Film and Literature Classification website, http://www.classificationoffice.govt.nz/blog/blog13-reasons-why.html.

29 Michael Holquist, "Corrupt Originals: The Paradox of Censorship," PMLA 109, no. 1 (1994): 17.
} 


\section{List of Sources}

\section{Archives New Zealand}

\section{Department of Internal Affairs, Head Office}

AAAC W3628 - Chief Censors Office: Film Posters and Assorted Records AAAC W4156 - Multiple Number Subject Files from the Film Censors Office AAAC W4303 - Multiple Number Subject Files AAAC W4442 - Multiple number subject files from the Film Censor's Office and a Department of Internal Affairs report on motion picture policies/legislation AAAC 6799 W4516 - Multiple Number Subject Files ("2nd Series") AAAC 7536 W5084 - Central filing system [fifth sequence] AAAC 7536 W5169 - Central filing system [fifth sequence] AAAC 7536 W5360 - Central filing system [fifth sequence]

Department of Internal Affairs, Head Office [record group]

ACGO 8333 - Central filing system [record group] ACGO 8405 - Film Censor's Office [record group]

\section{New Zealand Film Commission}


Office of Film and Literature Classification

ADNB 23133 - Daybook of Chief Censor or Films

ADNB 23134 - Video Censorship registers

ADNB 23136 - Film Censor's Office registered files

ADNB 23137 - Video Recordings Authority registered files

ADNB 24958 W5848 - Film Censorship Registers

\section{Alexander Turnbull Library}

Christendom. Turnbull Serials.

Newsletter, Society for the Promotion of Community Standards. WN NZ Pacific Serials

\section{Legislation}

Cinematograph-film Censorship Act 1916.

Cinematograph Films Act 1928.

Cinematograph Films Amendment Act 1934.

Cinematograph Films Act 1961.

Cinematograph Films Act 1976.

Films Act 1983.

Films Amendment Act 1990. 
Films, Videos and Publications Classification 1993.

Offensive Publications Act 1892.

Video Recordings Act 1987.

Video Recordings Act Amendment 1990.

\section{Interviews}

Interview with Arthur Everard, 14 April 2015.

Interview with Jane Wrightson, 8 June 2015.

Interview with Andrew Jack, 2 November 2015.

\section{Newspapers and Magazines}

Auckland Star.

Christchurch Star.

The Dominion.

Dominion Sunday Times.

Eugene Register-Guard.

Evening Post.

Illusions.

New Zealand Herald.

North \& South.

Northland Times.

NZ Listener. 
NZ Truth.

Otago Daily Times.

The Press.

Preview.

Sunday News.

Sunday Star.

Sunday Times.

Waikato Times.

Zealandia.

\section{Official Government Publications}

Bradley, Jane, and Alastair McKenzie. Video in New Zealand. Wellington: Department of Internal Affairs, 1988.

Christoffel, Paul. Censored: A short history of censorship in New Zealand. Wellington: Department of Internal Affairs, 1989.

Morris, Joanne, Hilary Haines and Jack Shallcrass. Pornography: Report of the Ministerial Committee of Inquiry. January 1989.

New Zealand Parliamentary Debates.

\section{Websites}

Arthur Everard, https://www.nzonscreen.com/person/arthur-everard/biography. 
Office of Film and Literature Classification online database,

http://www.classificationoffice.govt.nz/DDA/Pages/Screens/DDA/WelcomePage .aspx.

Office of Film and Literature Classification website,

http://www.classificationoffice.govt.nz/news/latest-news/media-release-13reasons-why.html

Office of Film and Literature Classification website, http://www.classificationoffice.govt.nz/blog/blog-13-reasons-why.html.

Refused-Classification.com, http://www.refusedclassification.com/censorship/films/henry-portrait-of-a-serial-killer-1986.html.

"What did 'Life of Brian' ever do for us?", http://www.telegraph.co.uk/culture/film/6679546/What-did-Life-of-Brian-ever-dofor-us.html.

\section{Secondary Sources}

Abbott, Stacey. "The Nightmare within the Everyday: The Horrific Visions of David Blyth." In New Zealand Filmmakers, edited by lan Conrich and Stuart Murray, 336-348. Detroit: Wayne State University Press, 2007.

Attwell, Feona, Vincent Campbell, I.Q. Hunter and Sharon Lockyer. "Introduction." In Controversial Images: Media Representations on the Edge, edited by Feona Attwell, Vincent Campbell, I.Q. Hunter and Sharon Lockyer, 1-18. Basingstoke: Palgrave Macmillan, 2013.

Aune, James Arnt. "From Corax to Coase: Rhetoric and Rational Choice Theory." In Communication and the Economy: History, Value and Agency, edited by Joshua S. Hanan and Mark Hayward, 95-120. New York: Peter Lang, 2014.

Babe, Robert E. Communication and the transformation of economics: Essays in information, public policy and political economy. Boulder: Westview Press, 1995. 
Bacchi, Carol. "Policy as Discourse: What does it mean? Where does it get us?" Discourse: studies in the cultural politics of education 21, no. 1 (2000): 45-57.

Baker, Michelle Mary. "Policing Publications: Sites of Censorship Classification Enforcement in New Zealand." Master's thesis, University of Canterbury, 2006.

Baldi, Alfredo. Schermi proibiti: la censura in Italia: 1947-1988. Venice: Marcilio, 2002.

Barker, Martin, ed. The video nasties: Freedom and censorship in the media. London: Pluto Press, 1984.

Barker, Martin. "Nasty politics or video nasties?" In The video nasties: Freedom and censorship in the media, edited by Martin Barker, 7-38. London: Pluto Press, 1984.

Barker, Martin. "Nasties': a problem of identification." In The video nasties: Freedom and censorship in the media, edited by Martin Barker, 104-118. London: Pluto Press, 1984.

Barker, Martin. "Sex, Violence and Videotape." Sight and Sound, 3.5 (1993): 10-12.

Barker, Martin. "The Newson Report: A case study in 'common sense'." In III Effects: The Media/Violence Debate, $2^{\text {nd }}$ ed., edited by Martin Barker and Julian Petley, 27-47. London: Routledge, 2001.

Barker, Martin, and Julian Petley. "Introduction." In III Effects: The Media/Violence Debate, edited by Martin Barker and Julian Petley, 1-10. London: Routledge, 1997.

Bayman, Louis. “Do Serial Killers Have Good Taste?”. In Murders and Acquisitions: Representations of the Serial Killer in Popular Culture, edited by Alzena MacDonald, 145-162. New York: Bloomsbury, 2013.

Benson-Allott, Caetlin. Killer Tapes and Shattered Screens: Video Spectatorship from VHS to File Sharing. Berkeley: University of California Press, 2013.

Boyd-Barrett, Oliver. "Theory in Media Research." In Mass Communication Research Methods: Volume 1, edited by Anders Hansen, 3-37. Los Angeles: Sage, 2009. 
Butler, Judith. Excitable speech: a politics of the performative. New York: Routledge, 1997.

Chandler, Daniel, and Rod Munday. A Dictionary of Media and Communication. Oxford: Oxford University Press, 2016. doi:10.1093/acref/9780199568758.001.0001.

Chang, Ha-Joon. Breaking the Mould: An Institutionalist Political Economy Alternative to the Neoliberal Theory of the Market and the State (Social Policy and Development Programme Paper Number 6). United Nations Research Institute for Social Development, 2001.

Church, David. "Of Manias, Shit, and Blood: The Reception of Salò as a 'Sick Film'." Participations: Journal of Audience \& Reception Studies 6, no. 2 (2009): 340372.

Clover, Carol J. Men, Women, and Chain Saws: Gender in the Modern Horror Film. London: BFI, 1992.

Collins, Richard B. "Foreword." In Global Issues: Censorship by Frank Caso, ix-xiii: New York: Facts on File, 2008.

Cook, Philip and Conrad Heilmann. "Two Types of Self-Censorship: Public and Private." Political Studies 61, no.1 (2013): 178-196.

Corner, John. "Finding Data, Reading Patterns, Telling Stories: Issues in the Historiography of Television." In Mass Communication Research Methods: Volume 1, edited by Anders Hansen, 241-249. Los Angeles: Sage, 2009.

Cox, C. Benjamin. "The Varieties of Censorial Experience: Toward a Definition of Censorship." The High School Journal 62, no. 8 (1979): 311-319.

Cunningham, Stuart and Terry Flew. "Reconsidering Media Economic: From Orthodoxies to Heterodoxies." Media Industries 2, no. 1 (2015): 1-18.

Cutfield, Lisa. "Silent Film and Censorship, New Zealand, 1908-1928." Honours thesis, University of Otago, 1994. 
Dalton, Derek, and Catherine Schubert. "When Classification Becomes Censorship: An Analysis of the Neutralisation and Resistance of Film Censorship in Contemporary Australia." Griffith Law Review 20, no. 1 (2011): 31-66.

Davison, W. Phillips. "The Third-Person Effect in Communication." The Public Opinion Quarterly 47, no. 1 (1983): 1-15.

Deacon, David, Michael Pickering, Peter Golding and Graham Murdock. "Dealing with Documentation." In Mass Communication Research Methods: Volume 4, edited by Anders Hansen, 281-311. Los Angeles: Sage, 2009.

Donaldson, Stephen. "The inquiry into "artistic merit" in the Films, Videos and Publications Classification Act 1993: how does it arise and what does it mean?" Master's thesis, Victoria University of Wellington, 2008.

Egan, Kate. Trash or treasure? Censorship and the changing meaning of the video nasties. Manchester: Manchester University Press, 2007.

Eldred-Grigg, Stevan. Pleasures of the flesh: Sex \& drugs in colonial New Zealand, 1840-1915. Wellington: Reed, 1984.

Elliott, John E. "Institutionalism as an Approach to Political Economy." Journal of Economic Issues 10, no. 1 (1978): 91-114.

Elster, Jon. "Introduction." In Rational Choice, edited by Jon Elster, 1-33. Oxford: Basil Blackwell, 1986.

Evans, Richard J. In Defence of History. London, Granta Books, 2000.

Falconer, Delia. “'We Don't Need to Know the Way Home”: The disappearance of the road in the Mad Max trilogy." In The Road Movie Book, edited by Steven Cohan and Ina Rae Hark, 249-270. London: Routledge, 1997.

Flew, Terry. "From Censorship to Policy: Rethinking Media Content Regulation and Classification." Media International Australia 88, no. 1 (1998): 89-98.

Ford, Kirsten. The Veblenian Roots of Institutional Political Economy (Working Paper No: 2011-07). 2011. http://economics.utah.edu/research/publications/2011_07.pdf

Freedman, Des. The Politics of Media Policy. Cambridge: Polity Press, 2008. 
Freshwater, Helen. "Towards a Redefinition of Censorship." Critical Studies 22 (2004): 225-245.

Gardner, Diana. "Censorious New Zealanders: Pornography, Corruption and Harm to Women." Master's thesis, University of Auckland, 1995.

Gilbert, Jarrod. Patched: The History of Gangs in New Zealand. Auckland: Auckland University Press, 2013.

Hallam, Julia, and Margaret Marshment. Realism and popular cinema. Manchester: Manchester University Press, 2000.

Hansen, Anders. "Editor's Introduction." In Mass Communication Research Methods: Volume 1, edited by Anders Hansen, xxiii-xxxiii. Los Angeles: Sage, 2009.

Hantke, Steffan. "Violence Incorporated: John McNaughton's "Henry: Portrait of a Serial Killer" and the Uses of Gratuitous Violence in Popular Narrative." College Literature 28, no. 2 (2001): 29-47.

Harsanyi, John C. "Advances in Understanding Rational Behaviour." In Rational Choice, edited by Jon Elster, 83-107. Oxford: Basil Blackwell, 1986.

Henry, Claire. Revisionist Rape- Revenge: Redefining a Film Genre. New York: Palgrave Macmillan, 2014.

Higginbotham, Virginia. Spanish film under Franco. Austin: University of Texas Press, 1988.

Hickin, Daniel. "How to Cope with the Death of Film Censorship." The Velvet Light Trap 63 (2009): 63-64.

Hill, Anthony Norwood. "In the Public Good: Film Censorship, the State and Hegemony." Master's thesis, Massey University, 1983.

Hill, Michael R. Archival Strategies and Techniques. Thousand Oaks: Sage, 1993. http://dx.doi.org/10.4135/9781412983471.

Hobbs, Simon. "Salò, or the 120 Days of Sodom: The Contemporary Distribution of Sexual Extremity." Cine-Excess. http://www.cine-excess.co.uk/salograve-orthe-120-days-of-sodom-the-contemporary-distribution-of-sexual-extremity.html. 
Hodgson, Geoffrey M. "Institutions and Individuals: Interaction and Evolution." Organization Studies 28, no. 1 (2007): 95-116.

Holquist, Michael. "Corrupt Originals: The Paradox of Censorship.” PMLA 109, no. 1 (1994): 14-25.

Ingrassia, Nathalie S. "Rape, Revenge and Remake: Meir Zarchi's Day of the Woman and Steven Monroe's I Spit on Your Grave." FORUM: University of Edinburgh Postgraduate Journal of Culture and the Arts, 13 (2011).

Jansen, Sue Curry. Censorship: the knot that binds power and knowledge. New York: Oxford University Press, 1991.

Kimber, Shaun. Henry: Portrait of a Serial Killer. Basingstoke: Palgrave Macmillan, 2011.

King, Nigel, and Christine Horrocks. Interviews in Qualitative Research. Los Angeles: Sage, 2010.

Kuhn, Annette. Cinema, censorship, and sexuality, 1909-1925. London: Routledge, 1988.

Laugier, Sandra. "The Holy Family." In Jean-Luc Godard's Hail Mary: Women and the Sacred in Film, edited by Maryel Locke and Charles Warren, 27-38. Carbondale: Southern Illinois University Press, 1993.

Lloyd Baugh, S.J. "Martin Scorsese's The Last Temptation of Christ: A Critical Reassessment of Its Sources, Its Theological Problems, and Its Impact on the Public." In Scandalizing Jesus? Kazantzakis's The Last Temptation of Christ Fifty Years On, edited by Darren J.N. Middleton, 173-192. New York: Continuum, 2005.

Locke, Maryel. "A History of the Public Controversy." In Jean-Luc Godard's Hail Mary: Women and the Sacred in Film, edited by Maryel Locke and Charles Warren, 1-9. Carbondale: Southern Illinois University Press, 1993.

Loshitzky, Yosefa. The radical faces of Godard and Bertolucci. Detroit: Wayne State University Press, 1995. 
Lucas, Brad E., and Margaret M. Strain. "Keeping the Conversation Going: The Archive Thrives on Interviews and Oral History." In Working in the Archives: Practical Research Methods for Rhetoric and Composition, edited by Alexis E. Ramset, Wendy B. Sharer, Barbara L'Eplattenier and Lisa S. Mastrangelo, 259277. Carbondale: Southern Illinois University Press, 2010.

Macnamara, Jim R. Mass Media Effects: A Review of 50 Years of Media Effects Research (CARMAN International Research Paper). 2003. Retrieved from http://www.masscom.com.au/book/papers/mass_media.html.

Maddison, Sarah, and Richard Denniss. An Introduction to Australian Public Policy: Theory and Practice. Cambridge: Cambridge University Press, 2009.

Mantzoukas, Stefanos. "Issues of Representation within Qualitative Inquiry." In Qualitative Research 2: Volume 3, edited by Alan Bryman, 3-19. Los Angeles: SAGE Publications, 2007.

March, James. "Bounded Rationality, Ambiguity, and the Engineering of Choice." In Rational Choice, edited by Jon Elster, 142-170. Oxford: Basil Blackwell, 1986.

Martin, Adrian. The Mad Max Movies. Sydney: Currency Press, 2003.

Mathews, Tom Dewe. Censored. London: Chatto \& Windus, 1994.

McCulloch, Gary. Documentary Research in Education, History and the Social Sciences. London: RoutledgeFalmer, 2004.

Miceli, Aldo. "Last Tango in Paris: Death, eroticism, and the female Oedipus." The Italianist 21, no. 1 (2001): 124-157.

Montagne, Albert. Histoire juridique des interdits cinématographiques en France, 1909-2001. Paris: Harmattan, 2007.

Moore, Nicole. “Censorship Is.” Australian Humanities Review 54 (2013): 45-65.

Morris, Meaghan. Identity Anecdotes: Translation and Media Culture. London: SAGE Publications, 2006.

Mosco, Vincent. The Political Economy of Communication. London: Sage, 1996. 
Moynihan, Carolyn. A Stand for Decency: Patricia Bartlett \& the Society for the Promotion of Community Standards 1970-1995. Wellington: Society for the Promotion of Community Standards, 1995.

Nelms, Gerald. "The Case for Oral Evidence in Composition Historiography." Written Communication 9, no. 2 (1992): 356-384.

Niedenführ, Matthias. "The Tug-of-War between Regulatory Interventions and Market Demands in the Chinese Television Industry." The Political Economy of Communication 1, no. 1 (2013): 90-110.

Nikander, Pirjo. "Interviews as Discourse Data." In The SAGE Handbook of Interview Research: The Complexity of the Craft, edited by Jaber F. Gubrium, James A. Holstein, Amir B. Marvasti and Karyn D. McKinney. Thousand Oaks: SAGE Publications, 2014. http://dx.doi.org/10.4135/9781452218403.

On, Maria. "Abusive pornography: recognising the harms and extending censorship." Master's thesis, Victoria University of Wellington, 2009.

Ovens, Jill and Jim Tucker. "A History of Newspapers in NZ." In Intro: A Beginner's Guide to Professional News Journalism, edited by Jim Tucker, 21-37. Wellington: New Zealand Journalists Training Organisation, 2004.

Pearce, Matthew. "Perspectives of Australian Broadcasting Policy." Continuum 14, no 3 (2000): 367-382.

Perloff, Richard M. "The Third Person Effect: A Critical Review and Synthesis." Media Psychology 1, no.4 (1999): 353-378.

Peters, B. Guy. Institutional Theory in Political Science: The 'New Institutionalism'. London: Pinter, 1999.

Peters, B. Guy. "Institutional theory: problems and prospects." In Debating institutionalism, edited by Jon Pierre, B. Guy Peters and Gerry Stoker, 1-21. Manchester: Manchester University Press, 2008.

Petley, Julian. Film and Video Censorship in Contemporary Britain. Edinburgh: Edinburgh University Press, 2011. 
Petley, Julian. "Are We Insane?' The 'Video Nasty' Moral Panic." In Moral Panics in the Contemporary World, edited by Chas Critcher, Jason Hughes, Julian Petley and Amanda Rohloff, 73-98. New York: Bloomsbury, 2016.

Pirie, Andrew. "Censorship of Films: Conflict in Focus." Master's thesis, Victoria University of Wellington, 1976.

Pomerance, Murray. The Eyes Have It: Cinema and the Reality Effect. New Brunswick: Rutgers University Press, 2013.

Post, Robert. "Censorship and Silencing." Bulletin of the American Academy of Arts and Sciences 51, no. 5 (1998): 32-35.

Rayner, Jonathan. "Embodying the Commercial: Genre and Cultural Affect in the Films of Geoff Murphy." In New Zealand Filmmakers, edited by lan Conrich and Stuart Murray, 152-168. Detroit: Wayne State University Press, 2007.

Rockett, Kevin. Irish film censorship: a cultural journey from silent cinema to Internet pornography. Dublin: Four Courts, 2004.

Rojas, Hernando, Dhavan V. Shah and Ronald J. Faber. "For the Good of Others: Censorship and the Third Person Effect." International Journal of Public Opinion Research 8, no. 2 (1996): 163-186.

Rose, James. The Texas Chain Saw Massacre. New York: Columbia University Press, 2014. ProQuest Ebook Central.

Schauer, Frederick. "The Ontology of Censorship." In Censorship and silencing: practices of cultural regulation, edited by Robert C. Post, 147-168. Los Angeles: Getty Research Institute for the History of Art and the Humanities, 1998.

Sconce, Jeffrey. "Spectacles of Death: Identification, Reflexivity, and contemporary Horror." In Film Theory Goes to the Movies, edited by Jim Collins, Hilary Radner and Ava Preacher Collins, 103-199. New York: Routledge, 1993.

Scott, John. A Matter of Record. Cambridge: Polity Press, 1990. 
Semren, Daniel. "Film classification systems in New Zealand and Germany: treatment of sex and violence". Master's thesis, Victoria University of Wellington, 2009.

Shaw, Sara E. "Reaching the parts that other theories and methods can't reach: How and why a policy-as-discourse approach can inform health-related policy." Health 14, no. 2 (2010): 196-212.

Shuker, Roy. "Video nasties': censorship and the politics of popular culture." New Zealand Sociology 1, no.1 (1986): 64-73.

Shuker, Roy, Roger Openshaw and Janet Soler. Youth, Media and Moral Panic in New Zealand (From Hooligans to Video Nasties). Palmerston North: Massey University, 1990.

Sigley, Simon. "Film culture: Its development in New Zealand, 1929-1972." PhD thesis, University of Auckland, 2003.

Sigley, Simon. "How The Road to Life (1931) Became the Road to Ruin: The Case of the Wellington Film Society in 1933." New Zealand Journal of History 42, no. 2 (2008): 196-215

Sigley, Simon. "Rites of Passage in Post-Second World War New Zealand Cinema: Migrating the Masculine in Journey for Three (1950)." In New Zealand Cinema: Interpreting the Past, edited by Barry Keith Grant, Alistair Fox and Hilary Radner, 153-174. Bristol: Intellect, 2011.

Sigley, Simon. Transnational Film Culture in New Zealand. Bristol: Intellect, 2013.

Starr, Marco. "J. Hills is alive: a defence of I Spit on Your Grave." In The video nasties: Freedom and censorship in the media, edited by Martin Barker, 48-55. London: Pluto Press, 1984.

Sterritt, David. The Films of Jean-Luc Godard: Seeing the Invisible. Cambridge: Cambridge University Press. 1999.

Stevens, Brad. Abel Ferrara: The Moral Vision. Godalming: FAB Press, 2004.

Streeck, Wolfgang. Taking capitalism seriously: Toward an institutionalist approach to contemporary political economy (Max-Planck-Institut für 
Gesellschaftsforschung Discussion Paper, No. 10/15). 2010.

http://www.econstor.eu/handle/10419/43282.

Symonds, Gwyn. The Aesthetics of Violence in Contemporary Media. New York:

Continuum, 2008.

Taylor, Steven J., Robert Bogdan and Marjorie L. DeVault. Introduction to Qualitative Research Methods: A Guidebook and Resource, $4^{\text {th }}$ Ed. Hoboken: Wiley, 2016.

Thompson, David. Last Tango in Paris. London: BFI, 1998.

Thompson, Peter A. "Neoliberalism and the political economies of public television policy in New Zealand." Australian Journal of Communication 38, no. 3 (2011): $1-16$.

Wagner, Ben. Global Free Expression - Governing the Boundaries of Internet Content. Springer, 2016.

Warren, Charles. "Whim, God and the Screen." In Jean-Luc Godard's Hail Mary: Women and the Sacred in Film, edited by Maryel Locke and Charles Warren, 10-26. Carbondale: Southern Illinois University Press, 1993.

Wasko, Janet. "The Political Economy of Communications." In Mass Communication Research Methods: Volume 2, edited by Anders Hansen, 3-26. Los Angeles: Sage, 2008.

Watson, Chris and Roy Shuker. In the Public Good? Censorship in New Zealand. Palmerston North: The Dunmore Press, 1998.

Weerakkody, Niranjala. Research Methods for Media and Communications, $2^{\text {nd }}$ ed. Melbourne: Oxford University Press, 2015.

Williams, Linda. "Film Bodies: Gender, Genre, and Excess." Film Quarterly 44, no. 4 (1991): 2-13.

Williams, Linda. Screening Sex. Durham: Duke University Press, 2008.

Winseck, Dwayne. "The Political Economies of Media and the Transformation of the Global Media Industries." In The Political Economies and the Transformation of the Global Media Industries, edited by Dwayne Winseck and Dal Yong Jin, 348. London: Bloomsbury Academic, 2011. 
Zittoun, Philippe. "Understanding Policy Change as a Discursive Problem." Journal of Comparative Policy Analysis: Research and Practice 11, no. 1 (2009): 65-82. 


\section{Filmography}

200 Motels. Directed by Tony Palmer and Frank Zappa. Bizarre Productions, 1971. The Adventures of Barry McKenzie. Directed by Bruce Beresford. Longford Productions, 1972.

All the President's Men. Directed by Alan J. Pakula. Warner Bros., 1976. Angel of Vengeance. Directed by Ted V. Mikels. Majestic Films, 1987. Angel Mine. Directed by David Blyth. ILA Films, 1978.

The Baby. Directed by Ted Post. Quintet Films, 1973.

Backroads. Directed by Phillip Noyce. Backroads Productions, 1977.

Bad Lieutenant. Directed by Abel Ferrara. Bad Lt. Productions, 1992.

The Born Losers. Directed by Tom Laughlin. Fanfare Films, 1967.

Bound for Pleasure. Directed by David Blyth. ILA Films, 2004.

Caligula. Directed by Tinto Brass. Penthouse Films International, 1979.

Cannibal Ferox. Directed by Umberto Lenzi. Dania Films, 1981.

Cannibal Holocaust. Directed by Ruggero Deodato. F.D. Cinematografica, 1980.

Cape Fear. Directed by J. Lee Thompson. Melville-Talbot Productions, 1962.

Chained Heat. Directed by Paul Nicolas. Heat GBR, 1983.

Circadian Rhythms. Directed by David Blyth. 1976.

Circleman. Directed by Damian Lee. Ruby and Rose Productions, 1987.

Class of 1984. Directed by Mark Lester. Guerrilla High Productions, 1982.

The Cycle Savages. Directed by Bill Brame. American International Pictures, 1969.

Damned if You Don't. Directed by Su Friedrich. Downstream Productions, 1987. Dance or Die. Directed by Richard W. Munchkin. Troma, 1987. 
Death by Dialogue. Directed by Tom DeWier. City Lights, 1988.

Death Mask. Directed by Jag Mundhra. Spencer Films, 1988.

Death Warmed Up. Directed by David Blyth. Tucker Production Company, 1984.

Deliverance. Directed by John Boorman. Warner Bros., 1972.

The Devils. Directed by Ken Russell. Russo Productions, 1971.

Dracula Erotica. Directed by Shaun Costello. Fat Bat Company, 1980.

Dream Maniac. Directed by David DeCoteau. Empire Pictures, 1986.

The Driller Killer. Directed by Abel Ferrara. Navaron Films, 1979.

Dying Time. Directed by Allan Kuskowski. North American Film Fund, 1990.

Faces of Death. Directed by Conan Le Cilaire. F.O.D. Productions, 1978.

Flesh Gordon. Directed by Michael Benveniste and Howard Ziehm. Graffiti Productions, 1974.

Flight of the Intruder. Directed by John Milius. Paramount Pictures, 1991.

Foxy Brown. Directed by Jack Hill. American International Pictures, 1974.

Fritz the Cat. Directed by Ralph Bakshi. Aurica Finance Company, 1972.

Good to See You Again, Alice Cooper. Directed by Joe Gannon. Penthouse

Productions, 1974.

Goodbye Pork Pie. Directed by Geoff Murphy. Pork Pie Productions, 1980.

The Gore Gore Girls. Directed by Hershell Gordon Lewis. Lewis Motion Picture Enterprises, 1972.

Hail Mary. Directed by Jean-Luc Godard. Sara Films, 1985.

Hard Ticket to Hawaii. Directed by Andy Sidaris. Malibu Bay Films, 1987.

Henry: Portrait of a Serial Killer. Directed by John McNaughton. Maljack Productions, 1986.

The Hills Have Eyes. Directed by Wes Craven. Blood Relations Co., 1977. 
I Spit on Your Grave. Directed by Meir Zarchi. Cinemagic Pictures, 1978.

I Spit on Your Grave. Directed by Steven R. Monroe. CineTel Films, 2010.

I Spit on Your Graves. Directed by Michael Gast. CTI, 1959.

Irreversible. Directed by Gaspar Noé. StudioCanal, 2002.

J.D.'s Revenge. Directed by Arthur Marks. American International Pictures, 1976.

Journey for Three. Directed by Michael Forlong. National Film Unit, 1950.

King of New York. Directed by Abel Ferrara. Reteitalia, 1990.

La Grande Bouffe. Marco Ferreri. Films 66, 1973.

The Last House on the Left. Directed by Wes Craven. Sean S. Cunningham Films. 1972.

Last Tango in Paris. Directed by Bernardo Bertolucci. Produzioni Europee Associati, 1972.

The Last Temptation of Christ. Directed by Martin Scorsese. Universal Pictures, 1988.

Life of Brian. Directed by Terry Jones. Handmade Films, 1979.

Mad Max. Directed by George Miller. Kennedy Miller Productions, 1979.

Mad Max 2. Directed by George Miller. Kennedy Miller Productions, 1981.

Mad Max: Fury Road. Directed by George Miller. Village Roadshow Pictures, 2015.

Maniac. Directed by William Lustig. Magnum Motion Pictures Inc., 1980.

Maniac. Directed by Franck Khalfoun. Canal+, 2012.

Merry Christmas Mr. Lawrence. Directed by Nagisa Oshima. Oshima Productions, 1983.

The Naughty Bits, Episode 2. Directed by José Barbosa. Top Shelf Productions, 2014.

Nightmares in a Damaged Brain. Directed by Romano Scavolini. Goldmine Productions, 1981. 
No Room at the Inn. Directed by Daniel Birt. British National Films, 1948.

Open House. Directed by Jag Mundhra. Intercontinental Releasing Corporation, 1987.

Out for Justice. Directed by John Flynn. Warner Bros., 1991.

Penitentiary III. Directed by Jamaa Fanaka. Cannon Films, 1987.

The Pom Pom Girls. Directed by Joseph Ruben. Crown International Pictures, 1976.

Queen of the Underworld. Directed by Sherman Wong. Win's Film Productions, 1991.

Reservoir Dogs. Directed by Quentin Tarantino. Dog Eat Dog Productions, 1992.

Sacred Sex. Directed by Cynthia Connop. Australian Broadcasting Corporation, 1991.

Salò, or the 120 Days of Sodom. Directed by Pier Paolo Pasolini. Produzioni Europee Associati, 1975.

Scum. Directed by Alan Clarke. BBC, 1977.

Scum. Directed by Alan Clarke. Berwick Street Films, 1979.

Sleeping Dogs. Directed by Roger Donaldson. Aardvark Films, 1977.

Snuff. Directed by Michael Findlay, Horacio Fredriksson and Simon Nuchtern. August Films, 1975.

Sudden Impact. Directed by Clint Eastwood. Warner Bros., 1983.

The Texas Chain Saw Massacre. Directed by Tobe Hooper. Vortex, 1974.

Truck Turner. Directed by Jonathan Kaplan. American International Pictures, 1974.

Turkey Shoot. Directed by Brian Trenchard-Smith. FGH, 1982.

Visions of Ecstasy. Directed by Nigel Wingrove. Axel Films Ltd., 1989.

Whore. Directed by Ken Russell. Cheap Date, 1991.

The Wild Angels. Directed by Roger Corman. American International Pictures, 1966.

The Wild One. Directed by László Benedek. Columbia Pictures, 1953. 
WR: Mysteries of the Organism. Directed by Dušan Makavejev. Neoplanta Film, 1971.

Young Guns. Directed by Christopher Cain. Morgan Creek Productions, 1988.

Zombie Flesh Eaters. Directed by Lucio Fulci. Variety Film, 1979 


\section{Appendix - Interview Documents}

\section{Arthur Everard interview schedule - 14 April 2015}

What changes in censorship practice did you observe during your time as Chief Censor?

In what ways did you ascertain the opinions of the wider public on censorship matters, and how did this factor into your decisions?

What other external factors were there regarding censorship decisions and your role as a censor? (such as overseas censorship practices and decisions)

Did you have an underlying philosophy on censorship that helped to guide your censorship decisions?

What was your conception of the concept of "injurious to the public good"?

Do you consider censorship to be more of an "art" or a "science"?

Do you consider there to be fundamental differences in the nature of censorship of film versus censorship of home video?

How did you feel about the way in which legislation covering home video censorship was handled? Did you have regular dealings with the Video Recordings Authority?

What recollections do you have regarding the classification/censorship of [name of film]?

- I Spit on Your Grave

- The Driller Killer

- The Last Temptation of Christ

- Hail Mary 
Did makers of New Zealand films ever consult the censor's office regarding censorship ratings prior to their films being formally submitted for classification?

\section{Jane Wrightson interview schedule - 8 June 2015}

What changes in censorship practice did you observe during your time as Chief Censor?

In what ways did you ascertain the opinions of the wider public on censorship matters, and how did this factor into your decisions?

How did you decide if a film required a formal consultation with members of the public?

What other external factors were there regarding censorship decisions and your role as a censor? (such as overseas censorship practices and decisions)

Did you have an underlying philosophy on censorship that helped to guide your censorship decisions?

What was your conception of the concept of "injurious to the public good"?

Do you consider censorship to be more of an "art" or a "science"?

Do you consider there to be fundamental differences in the nature of censorship of film versus censorship of home video?

How did you feel about the way in which legislation covering home video censorship was handled? Did you have regular dealings with the Video Recordings Authority? 
What recollections do you have regarding the classification/censorship of [name of film]?

- Henry: Portrait of a Serial Killer

- Salo, or the 120 Days of Sodom

Did makers of New Zealand films ever consult the censor's office regarding censorship ratings prior to their films being formally submitted for classification?

\section{Andrew Jack interview schedule - 2 November 2015}

In what ways is the process for classification of New Zealand films different from that of overseas films? Are films sometimes viewed before formal classification?

Do you have an overarching philosophy on the nature of censorship that guides you in your work?

How do you think that changes in technology have changed and will change the nature of censorship? 


\section{Film and Video Censorship in New Zealand, 1976-1993 - Information Sheet}

\section{Researcher: Duncan Anderson}

I am a PhD student in Film Studies at Victoria University of Wellington. As part of this degree I am undertaking a research project leading to a thesis. The project I am undertaking is an investigation of film and video censorship in New Zealand between 1976 and 1993, and involves both archival research and interviews with those directly involved with censorship during my period of investigation. This research project has received approval from the Victoria University Human Ethics Committee.

The interviews will be semi-structured, and will focus upon the process of censorship and key censorship decisions. Interviewees will be former censors and those involved directly in the film censorship process in other ways, such as film distributors. Interview length will likely vary depending on individual interviewees and the semi-structured nature of the interviews, but will likely be around half an hour to an hour. Archival research will inform the questions, and the interviews are intended to complement and expand upon information gained from archival sources. Sensitive personal information will not be a part of the interviews.

Interviewees may withdraw themselves (and any information they have provided) from this project at any time during or within 21 days of participation without having to give reasons. Information and opinions will be attributed to named interviewees in the final thesis unless anonymity is requested, but interview recordings will be kept securely by the researcher, and will be wiped at the end of the project, and all data will be wiped after five years following completion of the thesis. If anonymity is requested, information will still be used in the final thesis as long as its inclusion will not make the interviewee identifiable.

If you have any further questions or would like to receive further information about the project, please contact me at 021803366 or duncan.anderson@vuw.ac.nz, or my supervisor Dr. Peter Thompson, at the School of English, Film, Theatre, and Media Studies at Victoria University at 044636827 or peter.thompson@vuw.ac.nz. 


\section{CONSENT TO PARTICIPATE IN RESEARCH}

\section{Title of project: Film and Video Censorship in New Zealand, 1976-1993}

I have read and have understood an explanation of this research project.

$\square$ I understand that I may withdraw myself (and any information I have provided) from this project at any time during or within 21 days of participation without having to give reasons.

I consent to information or opinions which I have given being attributed to me in any reports on this research.

or

I wish to remain anonymous.

I understand that the interview will be recorded, and that recording of will be kept securely by the researcher, and will be wiped at the end of the project, and all data will be destroyed after 5 years.

I would like to receive a summary of the results of the research when it is completed.

\section{Signed:}

Name of participant:

Date:

\section{Contact details:}

